$\frac{46 / 1918}{1 / 3}$

PREPARED FOR THE U.S. DEPARTMENT OF ENERGY, UNDER CONTRACT DE-AC02-76-CHO-3073

PPPL-2800

UC-425

\section{PRINCETON PLASMA PHYSICS LABORATORY (PPPL) ANNUAL SITE ENVIRONMENTAL REPORT FOR CALENDAR YEAR 1990}

BY

\author{
J.R. STENCEL AND V.L. FINLEY
}

December 1991

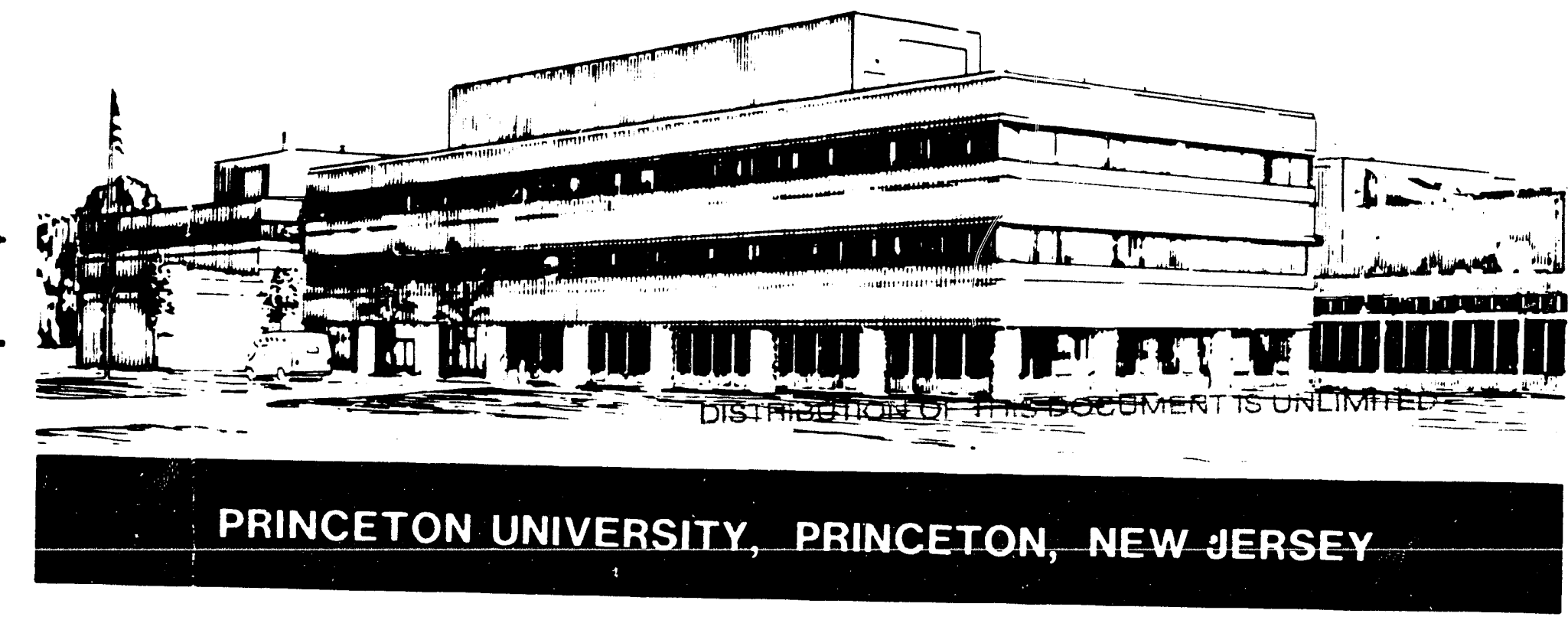




\section{NOTICE}

This report was prepared as an account of work sponsored by an agency of the United States Government. Neither the United States Government nor any agency thereof, nor any of their employees, makes any warranty, express or implied, or assumes any legal liability or responsibility for the accuracy, completeness, or usefulness of any information, apparatus, product, or process disclosed, or represents that its use would not infringe privately owned rights. Reference herein to any specific commercial produce, process, or service by trade name, trademark, manufacturer, or otherwise, does not necessarily constitute or imply its endorsement, recommendation, or favnring by the United States Government or any agency thereof. The views and opinions of authors expressed herein do not necessarily state or reflect those of the United States Government or any agency thereof.

\section{NOTICE}

This report has been reproduced directly from the best available copy.

Available to DOE and DOE contractors from the:

Office of Scientific and Technical Information P.O. Box 62

Oak Ridge, TN 37831;

Prices available from (615) 576-8401.

Available to the public from the:

National Technical Information Service

U.S. Department of Commerce 5285 Port Royal Road Springfield, Virginia 22161 $703-487-4650$ 
PPPL- -2800

DE92 003992

\section{PRINCETON PLASMA PHYSICS LABORATORY (PPPL) ANNUAL SITE ENVIRONMENTAL REPORT \\ FOR CALENDAR YEAR 1990}

\section{B Y}

J. R. Stencel

and

V. L. Finley

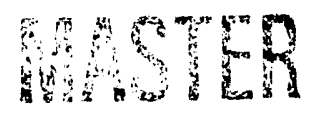

ESTRIBUTION OF THHS DOCUMVENT IS UNLMIIEO 
Table of Contents

List of Tables

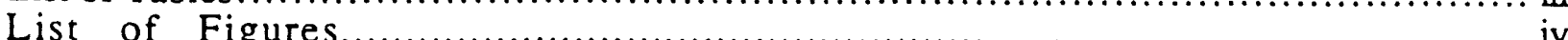

$1.0 \quad$ EXECUTIVE SUMMARY ......................................................

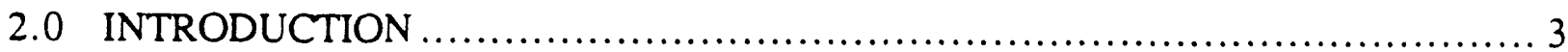

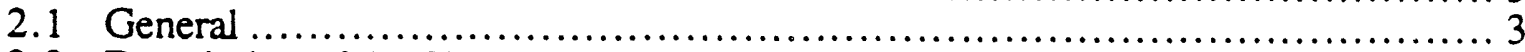

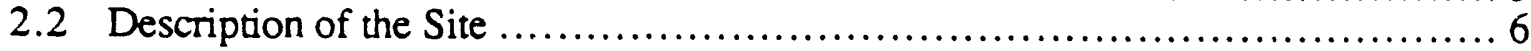

3.01990 ENVIRONMENTAL COMPLIANCE SEL F-ASSESSMENT .................. 7

3.1 Compliance Summary ................................................. 7

3.1.1 Comprehensive Environmental Response, Compensation, and Liability

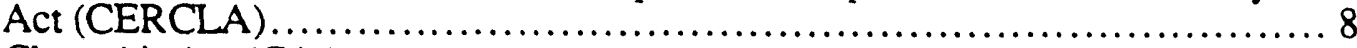

3.1 .2 Clean Air Act (CAA) ..................................................................... 9

3.1 .3 Clean Water Act (CWA) ........................................................ 9

3.1.4 Endangered Species Act (ESA) and National Historic Preservation Act ...... 10

3.1.5 Executive Order (EO) 11988, "Floodplain Management" and 11990, "Protection of Wetlands"......................................................... 10

3.1.6 Federal Insecticide, Fungicide, and Rodenticide Act (FIFRA) .................. 10

3.1.7 National Environmental Policy Act (NEPA) ....................................... 10

3.1.8 Resource Conservation and Recovery Act (RCRA) .......................... 11

3.1 .9 Safe Drinking Water Act (SWDA) ................................................ 11

3.1.10 Toxic Substance Control Act (TSCA) .................................... 11

3.2 Current Issues and Actions........................................................ 11

3.3 Environmental Permits................................................................... 12

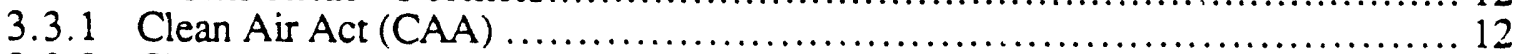

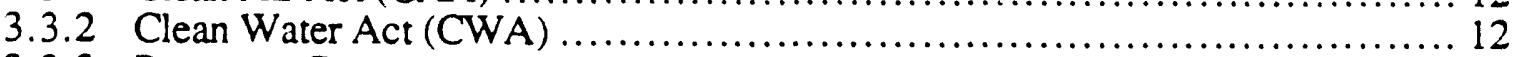

3.3.3 Resource Conservation and Recovery Act (RCRA) .......................... 13

3.3.4 Miscellaneous Permits.......................................................... 13

3.4 January 1 - April 1, 1991 Environmental Compliance Summary....................... 13

4.0 ENVIRONMENTAL PROGRAM INFORMATION N...................................... 14

4.1 Assessment of Radiation Dose to the Public .............................................. 14

4.2 Assessment of Nonradioactive Pollutants ............................................ 15

4.3 Pollution Prevention and Waste Minimization ...................................... 15

4.4 Regulations and Safety Criteria ........................................................ 16

4.5 Future Program Expansion........................................................... 16

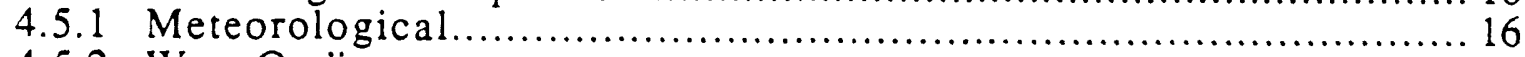

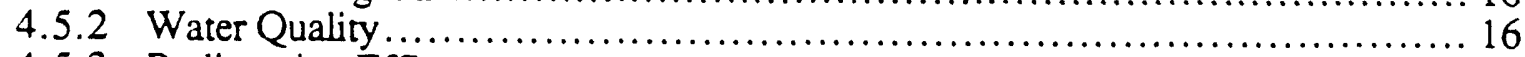

4.5.3 Radioactive Effluents........................................................... 17

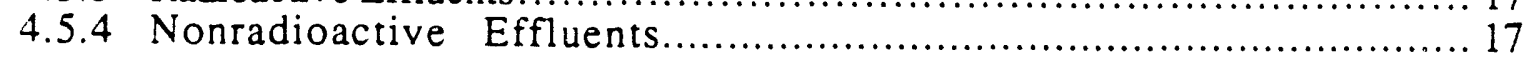

5.0 ENVIRONMENTAL RADIOLOGICAL PROGRAM INFORMATION ................ 18

5.1 Penetrating Radiation ......................................................... 18

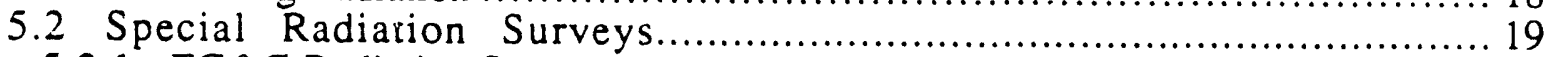

5.2.1 EG\&G Radiation Survey (Flyover) ............................................ 19

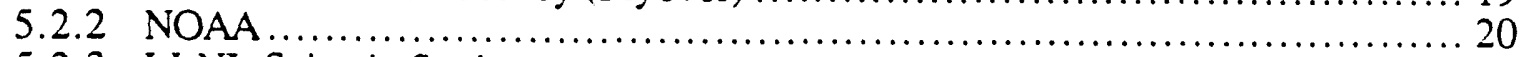

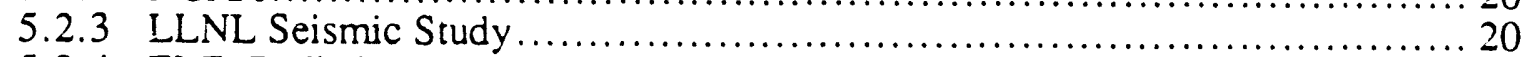

5.2.4 EML Radiation Measurements ……............................................... 21

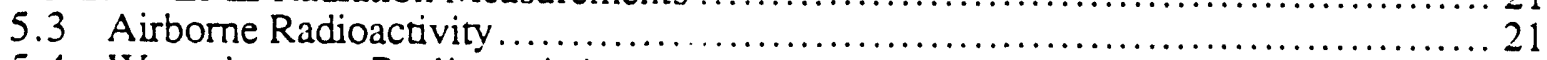

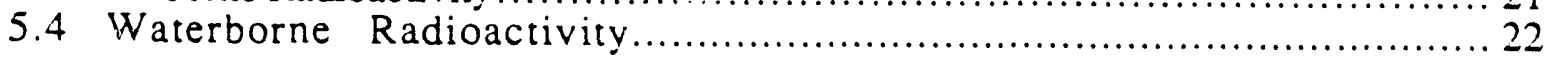




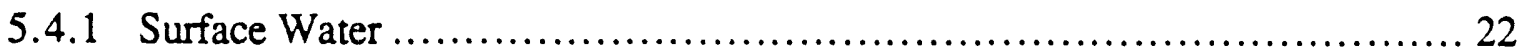

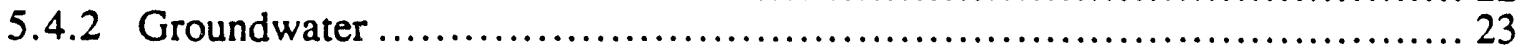

5.4 .3 Drinking Water.................................................................. 24

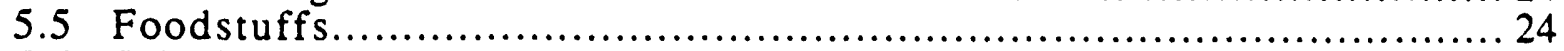

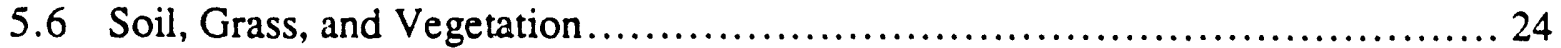

6.0 ENVIRONMENTAL NON-RADIOLOGICAL PROGRAM INFORMA TION.......... 25

6.1. Airborne Effluents........................................................... 25

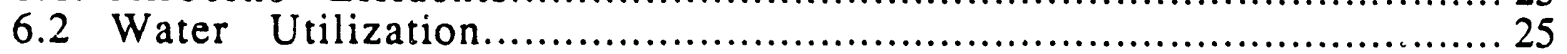

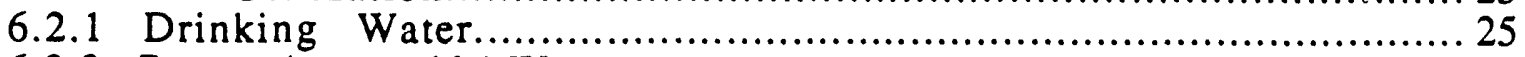

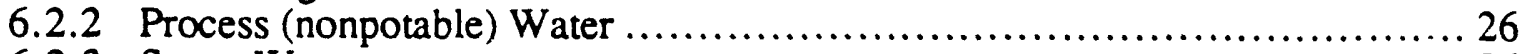

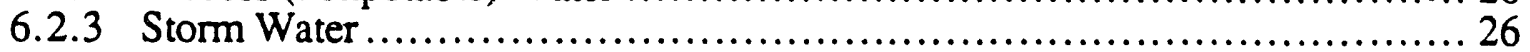

6.2 .4 Sanitary Sewage ................................................................ 27

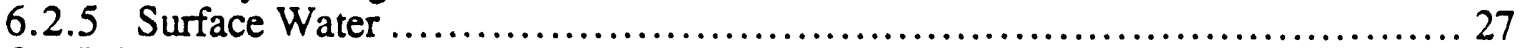

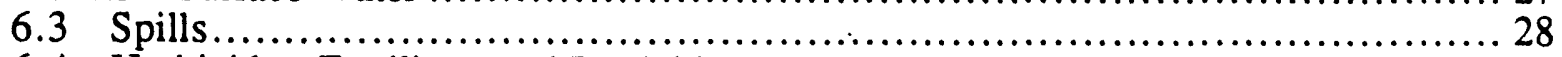

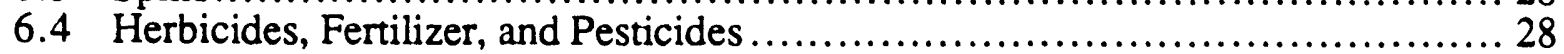

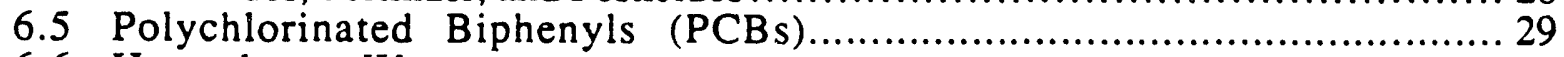

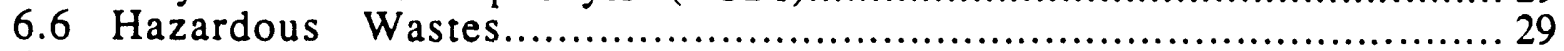

6.7 Special Non-Radiological Program Surveys ....................................... 30

6.7 .1 USGS ................................................................. 30

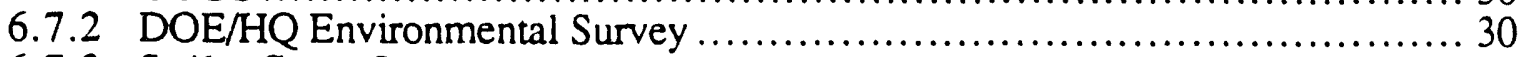

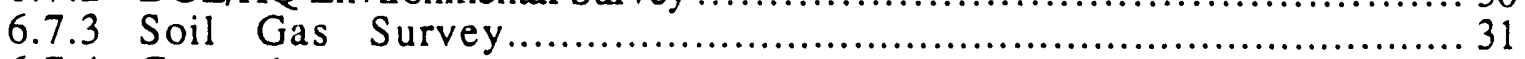

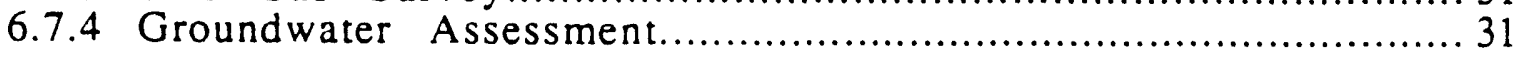

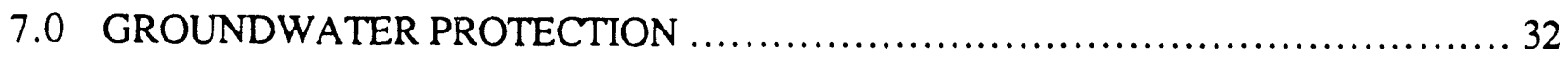

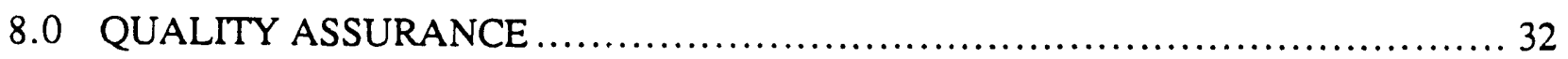

9.0 ACKNOWLEDGEMENTS ................................................ 33

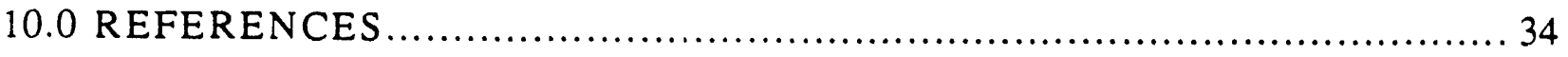




\section{List of Tables}

Table 1. TFTR/BPX Radiological Design Objectives and Regulaty Limits............ Page

Table 2. Critical Pathways.

Table 3

Table 4 .

Table 5.

Table 6.

Table 7.

Table 8.

Table 9.

Table 10.

Table 11.

Table 12.

Table 13.

Table 14.

Table 15.

Table 16.

Table 17.

Table 18.

Table 19.

Table 20.

Table 21.

Table 22.

Table 23.

Table 24.

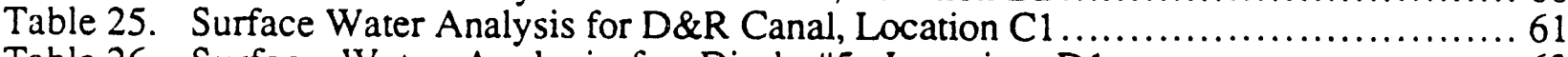

Monitoring Program Covering Critical Pathways ........................................... 40

Population of Municipalities Within 0-10 Miles of PPPL ........................... 41

Population of Counties Within 0-50 Miles of PPPL .......................... 42

Population of Metropolitan Areas Within 50 Miles of PPPL............................. 43

1985 Population Estimates Within Annular Sectors, 0-10 Miles ....................... 44

1995 Population Estimates Within Annular Sectors, 0-10 Miles ................... 45

2000 Population Estimates Within Annular Sectors, 0-10 Miles ...................... 46

2005 Population Estimates Within Annular Sectors, 0-10 Miles ....................... 47

2010 Population Estimates Within Annular Sectors, 0-10 Miles ................... 48

1985 Population Estimates Within Annular Sectors, 10-50 Miles....................... 49

1995 Population Estimates Within Within Annular Sectors, 10-50 Miles........... 50

2000 Population Estimates Within Within Annular Sectors, 10-50 Miles............ 51

2010 Population Estimates Within Within Annular Sectors, 10-50 Miles........... 52

Sectorized Population Data to 1 Mile................................................... 53

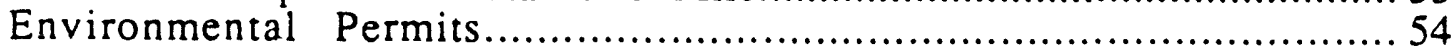

Summary of 1990 Airborne Emissions and Doses from TFTR ...................... 55

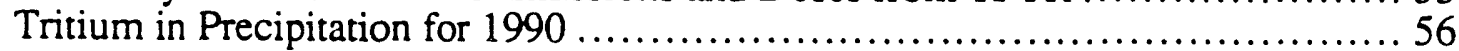

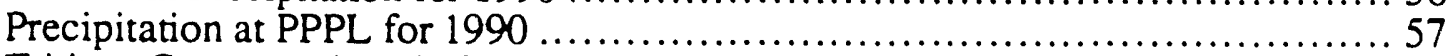

Tritium Concentrations in Surface Water and Ground water for 1990 ............... 58

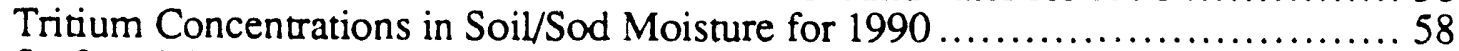

Surface Water Analysis for Bee Brook, Location B1 ................................ 59

Surface Water Analysis for Bee Brook, Location B2 ................................... 60

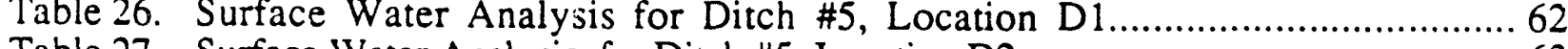

Table 27. Surface Water Analysis for Ditch \#5, Location D2 ............................6 63

Table 28. Surface Water Analysis for Ditch \#5, Location D2 (NJPDES) ......................6 64

Table 29. Water Analysis for Water Supply, Location E1 ................................. 65

Table 30. Surface Water Analysis for the Millstone River, Location M1 ………............... 66

Table 31. Surface Water Analysis for Plainsboro, Location P1 .................................... 67

Table 32. Surface Water Analysis for Plainsboro, Location P2 …............................. 68

Table 33. Detention Basin Influent Analysis (NJPDES) …..................................... 69

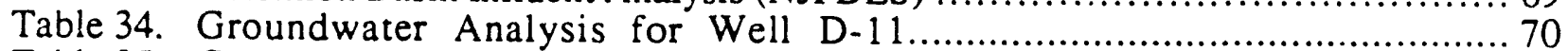

Table 35. Groundwater Analysis for Well D-12_................................................. 71

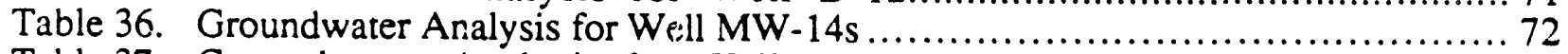

Table 37. Groundwater Analysis for Well MW-15 …........................................... 73

Table 38. Groundwater Analysis for Well MW-16 .............................................. 74

Table 39. Groundwater Analysis for Well TW2..................................................... 75

Table 40. Groundwater Analysis for Well TW3 3....................................................... 76

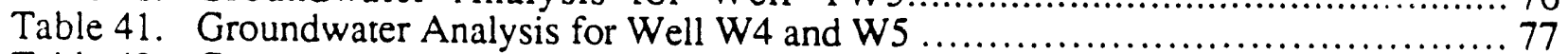

Table 42. Groundwater Base Neutral Analysis................................................. 78

Table 43. Groundwater Volatile Organics Analysis (May 90) .................................... 80

Table 44. Groundwater Volatile Organics Analysis (August 90) ............................... 82

Table 45. Miscellaneous Data for Groundwater Wells................................................ 83

Table 46. General Chemistry for Groundwater Wells ............................................ 84

Table 47. Fertilizer, Pesticides, and Herbicide Application ….................................. 85

Table 48. PPPL REML QA/QC from EPA/Las Vegas and DOE/EML …..................... 86

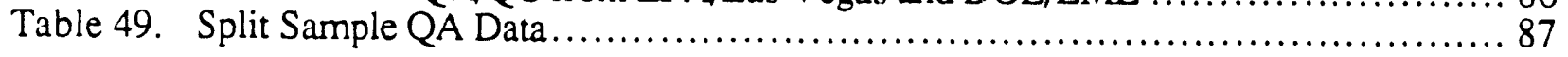




\section{List of Figures}

Figure 1. The Princeton Beta Experiment-Modification (PBX-M) Page

Figure 2. The Tokamak Fusion Test Reactor (TFTR) ..................................... 89

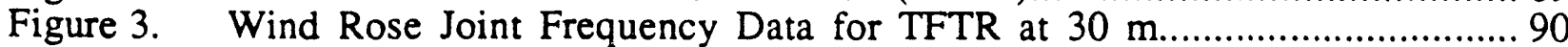

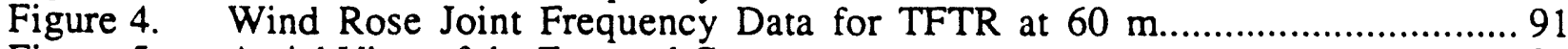

Figure 5. Aerial View of the Forrestal Campus ......................................... 92

Figure 5. C- and D-Sites of the Forrestal Campus, PPPL ............................... 93

Figure 7. $\quad 80 \mathrm{~km}(50$-mile) Radius of PPPL Site ..................................... 94

Figure 8. Immediate Site Vicinity (5 Mile Radius) .......................................... 95

Figure 9. Layout of James Forrestal Campus ........................................ 96

Figure 10. 1985 Population Estimates Within Annular Sectors (0-10 Miles) ................... 97

Figure 11. 1995 Population Projections Within Annular Sectors (0-10 Miles)............. 98

Figure 12. 2000 Population Projections Within Annular Sectors (0-10 Miles)............... 99

Figure 13. 2005 Population Projections Within Annular Sectors (0-10 Miles)............... 100

Figure 14. 2010 Population Projections Within Annular Sectors (0-10 Miles) ............... 101

Figure 15. 1985 Population Projections Within Annular Sectors (10-50 Miles) .............. 102

Figure 16. 1995 Population Estimates Within Annular Sectors (10-50 Miles) ............... 103

Figure 17. 2000 Population Estimates Within Annular Sectors (10-50 Miles) ............... 104

Figure 18. 2005 Population Estimates Within Annular Sectors (10-50 Miles) .............. 105

Figure 19. 2010 Population Estimates Within Annular Sectors (10-50 Miles) ................ 106

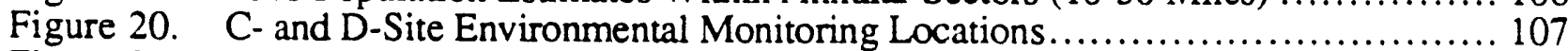

Figure 21. Millstone River Basin Offsiie Water Sample Locitions ........................ 108

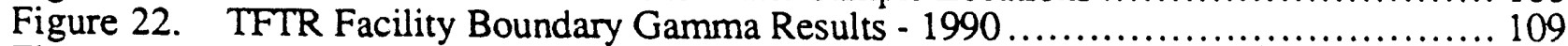

Figure 23. TFTR Facility Boundary Neutron Results - 1990..................................110

Figure 24. Tritium Oxide (HTO) in Air - 1990 ....................................... 111

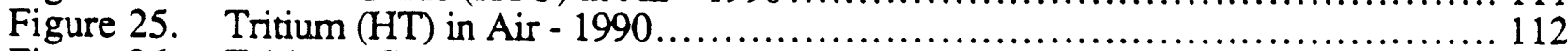

Figure 26. Tritium Concentration in Off-Site Surface Water..................................... 113

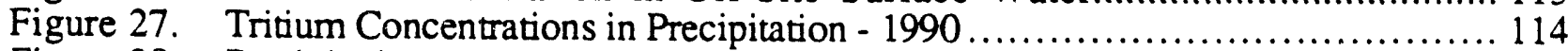

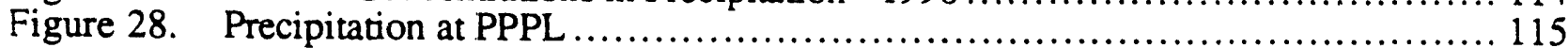

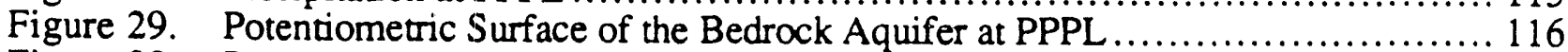

Figure 30. Potential Flow Paths of Spilled Water......................................... 117

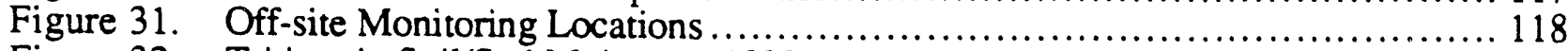

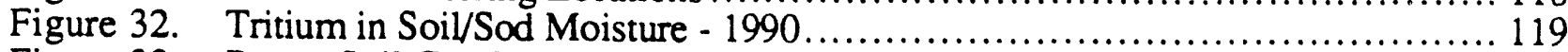

Figure 33. Petrex Soil Gas Survey Sample Points........................................... 120

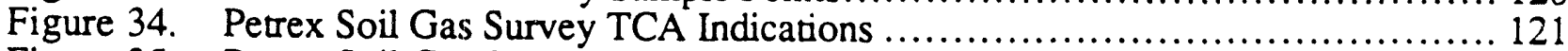

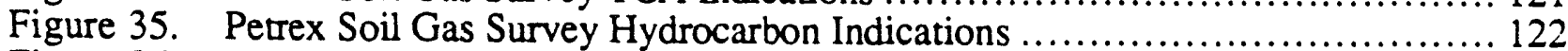

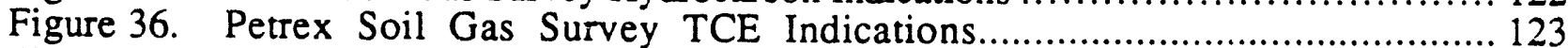

Figure 37. Petrex Soil Gas Survey PCE Indications......................................... 124

Figure 38. EPA-Las Vegas QA/QC Water Samples for Gamma .............................. 125

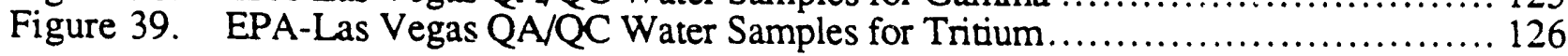




\subsection{EXECUTIVE SUMMARY}

During Calendar Year 1990 (CY90), there were no accidents, incidents, or occurrences that had a significant impact on PPPL facilities, the environment, or program operations. Assessment of the cleanup of underground storage tank (UST) hydrocarbons discovered in 1988 was enhanced by doing a soil gas test over the entire 72 acres leased to the Department of Energy (DOE) by Princeton University. The Petrex soil gas evaluation [Ne90] indicated solvents in several areas at the site which are related to past practices. A groundwater assessment program was begun at the end of 1990 with the placement of 16 wells and two piezometers emplaced under the guidance of the New Jersey Department of Environmental Protection (NJDEP). The results from this assessment will clarify whether or not any groundwater cleanup will be required because of past UST leaks or solvent use practices. Lead, which was indicated in two wells during one sampling period in 1989, did not show any positive results in 1990 . One other well indicated a lead level during one sampling period at the detection level. Follow-up sampling did not show any positive results.

A waste minimization review was accomplished by an outside contractor in 1990 . This review recognized the many steps taken by PPPL prior to any formal DOE program and recommended some steps to further reduce the use of hazardous materials and waste disposal requirements. Several non-toxic cleaners were compared to solvent-based cleaners with surprisingly good results. In 1991, the Laboratory will do further tests in the laboratory environment for compatibility and effectiveness and then introduce these new materials for routine use.

Weed control, grass fertilization, and pesticide control was accomplished by outside certified contractors in accordance with EPA regulations. Transformers and capacitors containing Polychlorinated biphenyls (PCB) oils were removed from service and disposed of in accordance with prepared schedules and EPA regulations. At the end of 1990 there were no PCB ransformers and only 661 large regulated PCB capacitors left on site.

Surface water analyses for both radioactive and nonradioactive pollutants have shown nothing above normally expected background values. Ambient tritium levels at less than $100 \mathrm{pCi} /$ iter $(3.7 \mathrm{~Bq} / \mathrm{liter})$ were measured in on-site well water. These data are in agreement with previous measurements by PPPL and the U.S. Geological Survey (USGS) results [St88c, St91]. Soil and vegetation samples were collected and analyzed for free 
water tritium as part of the continuing baseline studies. No studies have been undertaken, to date, to look at organically bound tritium (OBT).

Off-site surface water, soils, and biota continued to be analyzed for radioactive baselines in CY90. Passive tritium monitors, tested in field modeling experiments in Canada in 1987 [Gr88a], were used in four on-site area monitors, one stack monitor, and one off-site monitor. Six off-site locations within $1 \mathrm{~km}$ of TFTR were sited and will be presented to the local government planning board in 1991 for placement as off-site tritium air monitors. These differential atmospheric tritium samplers (DATS) are high sensitivity monitors which are able to detect changes in the ambient levels [Gr88b].

Radiation exposure, via airborne effluents into the environment, is at insignificant levels. A tritium stack monitor was added to the Tokamak Fusion Test Reactor (TFTR) stack even though it was not required by National Emission Standard for Hazardous Air Pollutants (NESHAPs) requirements. From deuterium-deuterium (D-D) fusion reactions during TFTR experimental operations, less than $1.1 \mathrm{Ci}(41.3 \mathrm{GBq})$ of tritium was produced in 1990. This included controlled tritium releases to the air and less than $.485 \mathrm{mCi}(17.9$ $\mathrm{MBq}$ ) of tritium oxide (HTO) to the sanitary sewer. Prompt radiation is detectable at extremely low levels during high-power pulses from TFTR by using high sensitivity instrumentation. A special study was conducted in 1990 by the DOE Environmental Measurements Laboratory (DOE/EML) to verify former PPPL Health Physics (HP) Branch measurements. The EML measurements confirmed the acceptability of HP neutron dose equivalent measurements [Ku91]. The integrated dose equivalent at the site boundary, from TFTR operations was less than 1 mrem $(0.01 \mathrm{mSv})$ for CY90 for measured, prompt radiacion plus calculated tritium and air activation releases [Gi91].

PPPL has emphasized environment, safety, and health (ES\&H) in accordance with DOE requirements at all of their facilities. The expectations are Liat the Laboratory will excel in ES\&H as it has already done in its fusion research program. The efforts are geared not only to full compliance with local, state, and federal regulations, but to a level of excellence which includes state-of-the-art monitoring and best management practices.

\footnotetext{
- In all cases used in this report, the whole body is the critical organ and the term dose equivalent can be considered to be synonymous with the term effective dose equivalent.
} 


\subsection{INTRODUCTION}

\subsection{General}

This report gives the results of the environmental activities and monitoring programs at the Princeton Plasma Physics Laboratory (PPPL) for CY90. The repoit is prepared to provide the U.S. Department of Energy (DOE) and the public with information on the level of radioactive and nonradioactive pollutants, if any, added to the environment as a result of PPPL operations, as well as environmental initiatives, assessments, and programs. The objective of the Annual Site Environmental Report is to document evidence that DOE facility environmental protection programs adequately protect the environment and the public health.

The Princeton Plasma Physics Laboratory has engaged in fusion energy research since 1951 and in 1990 had one of its two large tokamak devices in operation: namely, the Tokamak Fusion Test Reactor (TFTR). The Princeton Beta Experiment-Modification $(\mathrm{PBX}-\mathrm{M})$ is undergoing new modifications and upgrades for future operation. A new machine, the Burning Plasma Experiment (BPX)-formerly called the Compact Ignition Tokamak (CIT)-is under conceptual design, and it is awaiting the approval of its draft Envirorımental Assessment (EA) report by DOE Headquarters (HQ). This report is required under the National Environmental Policy Act (NEPA). The long-range goal of the U.S. Magnetic Fusion Energy Research Program is to develop and demonstrate the practical application of fusion power as an alternate energy source.

The Princeton Beta Experiment (PBX), the predecessor of PBX-M, after achieving a greater than $5 \%$ beta (ratio of plasma pressure to magnetic pressure) in CY84 experiments, was shut down at the end of 1985 to undergo modifications to permit further examination of theoretical predictions on plasma shaping and stabilization of kink modes by means of a close-fitting conducting wall. The addition of new coils and stabilizer plates within the vessel, new power supplies, and a new control system began in 1986. The modified device, PBX-M (Fig. 1), came back into operation in October 1987. In CY88, an indentation of the plasma of $25 \%$ was achieved, lower $\mathrm{q}(\mathrm{a})$ values obtained, and $\mathrm{H}$-modes at lower power attained. In CY89, the effectiveness of the passive plates in stabilizing kink modes and access to higher plasma pressure $(\beta \sim 6.8 \%$ and $\beta>4 \times \beta$ Troyon $)$ were assessed. A Safety Assessment Document (SAD) was published for the PBX in 1984 [F184] which indicated that the PBX did not pose any potential environmental concerns. A 
new SAD published for the PBX-M in 1988 reached the same conclusion [St88a]. A third SAD is under review and will be approved prior to the start-up of the upgraded PBX-M in FY92.

The TFTR (Fig. 2), which had its first full year of operation in CY83, had an increase in total neusion production in 1987 to a yearly total of $3 \times 10^{18}$ [He88], in 1988 to a yearly total of $9.04 \times 10^{18}$ [He89], in 1989 of $6.4 \times 10^{18}$ [Ja90a], and in 1990 of $2.3 \times 10^{19}$ [Ja90b]. The higher neutron production has increased the activation level of the machine to the point where health physics surveys are required in the test cell following a machine run and before any personnel entry is permitted for inspection, routine maintenance, or installation work. In addition, tritium from D-D reactions, which was absorbed in graphite and measured during the opening of the vessel in 1987, 1988, and 1990, posed the first known health physics contamination challenges for any tokamak operations. The experience gained from the 1987 opening was beneficial for the similar openings in 198889 and has helped to streamline operations for the 1990-91 opening.

The TFTR is a toroidal magnetic fusion energy research device in which a deuteriumtritium (D-T) plasma will be magnetically confined and heated to extremely high temperatures by neutral-beam injectors. A major achievement in 1986 was an increase in neutron production and fusion power by operating in what is now called the "supershot" pulse mode. Using this technique, a new record temperature of greater than 400 million degrees Celsius has been achieved. Ion Cyclotron Radio-Frequency (ICRF) heating became operational in 1988. The D-T operations were scheduled to begin in 1990; however, reprogramming and a budget cut announced in November 1988 have resulted in a schedule delay so that D-T experiments will begin in mid 199נ. The safety analyses completed for this program are addressed in Safety Analysis Reports for the Project [PSAR78 and FSAR82]. In 1988, the Final Safety Analysis Report (FSAR) was being updated to reflect operational requirements and parameters using tritium. This effort was initiated again in FY91 and is expected to be completed in 1992.

Although PPPL operates as an unfenced site, with access controls for security purposes, it is considered to be open to the public for environmental purposes. This free access has necessitated a thorough evaluation of the on-site discharges as well as the potential for offsite releases of radioactive and toxic nonradioactive effluents. An extensive monitoring program, tailored to these needs, has been instituted and expanded over recent years. The PPPL radiological environmental monitoring program generally follows the guidance given 
in two DOE reports: namely, A Guide for: Environmental Radiological Surveillance at U.S. Department of Energy Installations [Co81] and Environmental Dose Assessment Methods for Normal Operations at DOE Nuclear Sites (PNL-4410) [St82]. This includes adherence to the standards given in DOE Orders, in particular, DOE Order 5400.5 [DOE90a], which pertains to permissible dose equivalents and concentration guides and gives guidance on maintaining exposures "to as low as reasonably achievable" (ALARA). On January 1, 1990, DOE Order 5480.11 guidelines came into effect [DOE89]. While this order did not have a major impact on PPPL operations, the order did incorporate some changes in personnel monitoring requirements. DOE Order 5400.1 [DOE90b] requires an environmental monitoring plan. This plan will be completed in CY91. Specific criteria for implementing these standards on TFTR are contained in a TFTR Operational Safety Requirement (OSR/TFTR/0-2F-C). The new, approved version of this OSR, which is applicable to both TFTR and BPX, is shown in Table 1.

An environmental survey was conducted in June 1988 by DOE/HQ as part of an intensive evaluation at all DOE sites. No significant environmental concerns surfaced at PPPL as a result of this audit. An oil spill in 1988 by an outside vendor has led to a project of incorporating its cleanup with underground storage tank leak elimination and their replacement. In addition, groundwater contamination was a concern, and a Petrex soil gas survey was accomplished over the entire site in the spring of 1990 [Ne90]. Results from the soil gas survey, the UST issue, and New Jersey Pollutant Discharge and Elimination System (NJPDES) permit requirements prompted a groundwater assessment program, which is discussed in more detail below.

The emphasis of the radiation monitoring program has been placed on exposure pathways appropriate to fusion energy projects at PPPL. These pathways include external exposure from direct penetrating radiation and, eventually, during D-T, from airborne radionuclides, such as ${ }^{41} \mathrm{Ar},{ }^{13} \mathrm{~N},{ }^{16} \mathrm{~N}$, and internal exposure from radionuclides, such as ${ }^{3} \mathrm{H}$ in air and water. Six, major, critical pathways are considered as appropriate (see Table 2). Prompt radiation, i.e., that which is emitted immediately during operationis, was also considered and is being measured. The monitoring program, as envisicined by the TFTR Final Safety Analysis Report [FSAR82], has been updated to reflect the current environment around TFTR (see Table 3). At present, the radioactive pollutant potential to the environment by any pathway is essentially nonexistent. Small amounts of tritium are produced from D-D reactions [approximately $1.1 \mathrm{Ci}(41.3 \mathrm{GBq})$ in 1990 if all neutrons measured are assumed to be D-D produced]. A tritium monitor was installed on the TFTR stack in late 1990. 
Low levels of tritium (concentrations less than levels defined as radioactive materials by the Department of Transportation) are now detectable in pump oils. Also, tritiated water (HTO) was detected in the vacuum vessel air (outgassing from the carbon tiles) during the 1987 maintenance and upgrade period [St88b] as well as during the 1988-89 and 1990-91 opening.

Preliminary meteorological considerations and associated methodology, which were established at the time of the installation of PPPL's first meteorological tower, were reported in Section 2 of the TFTR FSAR. Subsequently, improved methodologies were implemented, and a new meteorological tower was erected and began operation in November 1983 [Mc83]. The improved measurements and methodologies are being included in the updated FSAR being prepared for tritium operations. Data have been collected for seven years using the monitors on the new tower. Wind-rose plots from the data for the first six years (1984-89) are shown in Figs. 3 and 4 [Ku89]. A tracer gasrelease test was conducted during the period from July to September 1988 to look at sitespecific air-diffusion parameters (also, see 5.2.2 below). These tests were commissioned to determine actual site conditions versus model predictions in relation to future activities. Ti.e test results indicated that actual dispersion and dilution of effluents in the vicinity of PPPL is enhanced by up to a factor of 16 over that predicted by Nuclear Regulatory Commission approved standard Gaussian diffusion models [St89]. Additionally, as a result of these tracer gas-release tests, a 10-m wind speed and wind-direction sensor was added to the meteorological tower in 1990 to monitor PPPL on-site meteorology more precisely. The U.S. Environmental Protection Agency (EPA) has been petitioned through the Princeton Area Office (DOE/PAO) to use the more realistic $\chi / \mathrm{Q}$ values from this test in the AIRDOS-EPA model used for the National Emission Standard for Hazardous Air Pollutants (NESHAPs) calculations. Approval is expected in 1991.

\subsection{Description of the Site}

The Princeton Plasma Physics Laboratory is located at the C- and D-sites of the James Forrestal Research Campus of Princeton University (Figs. 5 and 6). As shown in Fig. 7, the location is in central New Jersey within Middlesex County. The site is surrounded by undisturbed areas with virgin forest, open grass areas, an airplane runway, and a small brook (Bee Brook) running next to its eastern boundary. The closest urban centers are New Brunswick, 14 miles to the northeast, and Trenton, 12 miles to the southwest. Major metropolitan areas, including New York City, Philadelphia, and Newark, are within 50 
miles of the site. As shown in Fig. 8, the municipalities of Princeton, Plainsboro, Kingston, West Windsor, and Cranbury, among others, are in the immediate vicinity of the site. Also, the main canipus of Princeton University, located primarily within the Borough of Princeton, is approximately three miles to the west of the site. The general layout of the facilities at the C- and D-sites of Forrestal Campus is indicated in Fig. 9; the specific location of TFTR is at D-site.

A demographic study was completed in CY87 as part of the requirement for the Environmental Assessment for the Burning Plasma Experiment (BPX) [Be87a]. Other information gathered and updated from previous TFTR studies included socioeconomic information [Be87b] and an ecological survey [En87]. The demographic data were based on the 1980 census and show both estimated and projected data out to the year 2010 (Tables 4 to 16 and Figs. 10 to 19) in a zone from 1 mile out to 50 miles.

The PPPL site is in the center of a highly urbanized region extending from Boston, Massachusetts, to Washington, D.C., and beyond. The previous population projections for the states of New Jersey, New York, and Pennsylvania had indicated a substantial population increase within 50 miles of the PPPL site. The actual change from 1970 to 1980, as indicated by the census in these two years, was not as large as had been expected. In fact, the population in New York City and Philadelphia de: ased. The Princeton area continues to experience a substantial increase in new business moving into the Route 1 corridor near the site. This increase, however, has not been as great as the projections had indicated. As a summary, population data were divided inio annular sectors. It was prepared in 1986 for use with several standard codes used for the determination of off-site dose equivalent due to the release of activated air radionuclides and tritium [Ko86a]. Table 16 shows data supplied by the Princeton Forrestal Center on the population within one mile of the TFTR site. The numbers indicated have been divided by four to obtain an equivalent exposure for habitation [Ko86b].

\subsection{ENVIRONMENTAL COMPLIANCE SELF-ASSESSMENT}

\subsection{Compliance Summarv}

It is PPPL's considered intention to be in compliance with all applicable state, federal, and local environmental regulations. As a result of self-assessments and DOE Tiger Team acti..ies, PPPL will enhance its compliance efforts, especially in the area of strict 
documentation requirements. The status of each applicable environmental statute is listed below:

\subsubsection{Comprehensive Environmental Response. Compensation, and Liability Act (CERCLA)}

The PPPL is not involved with CERCLA mandated cleanups or compliance activities. RCRA cleanup activities for underground storage tanks have a low probability of triggering a CERCLA activity. Presently, CERCLA is only invoked under the requirements for SARA Title III for which PPPL is in compliance.

\section{Emergency Planning and Community Right to Know Act. SARA Title III.}

Title III of the 1986 SARA amendments to CERCLA created a system for planning responses to emergency situations involving hazardous materials and for making information regarding the use and storage of hazardous materials available to the public. Under SARA Title III, PPPL is required to provide an inventory of hazardous substances stored on the site, Materials Safety Data Sheets (MSDS), and completed SARA Tier I forms listing each hazardous substance stored in quantities above a certain threshold planning quantity (typically 10,000 pounds, but lower for certain compounds) to applicable emergency response agencies. The table on page 9 lists hazardous compounds at PPPL, reported under SARA Title III for 1990.

Section 304 of SARA Title III requires that the Local Emergency Planning Committee (LEPC) and state emergency planning agencies be notified of accidental or unplanned releases of certain hazardous substances to the environment. In order to ensure compliance with such notification provisions, PPPL Procedure EP-OP-003, Spill Reporting, includes SARA Title III requirements.

The New Jersey Department of Environmental Protection (NJDEP) administers the SARA Title III reporting for EPA and has modified the Tier I form to include SARA Title III reporting requirements and NJDEP reporting requirements. 
HAZARD CLASS

\begin{tabular}{|l|c|c|c|c|c|}
\hline & Fire & $\begin{array}{c}\text { Sudden } \\
\text { Release } \\
\text { of } \\
\text { Pressure }\end{array}$ & Reactive & $\begin{array}{c}\text { Acute } \\
\text { Health } \\
\text { Hazard }\end{array}$ & $\begin{array}{c}\text { Chronic } \\
\text { Health } \\
\text { Hazard }\end{array}$ \\
\hline Ammonia & & $\boldsymbol{V}$ & & $\checkmark$ & \\
\hline Bromotrifluoromethane & & $\checkmark$ & & $\checkmark$ & \\
\hline Carbon dioxide & & $\checkmark$ & & $\checkmark$ & \\
\hline Dichlorodiflouromethane & & $\checkmark$ & & $\checkmark$ & \\
\hline Fuel Oil & $\checkmark$ & & & & \\
\hline Gasoline & $\checkmark$ & & & & $\checkmark$ \\
\hline Helium & & $\checkmark$ & & & \\
\hline Nitrogen & & $\checkmark$ & & & \\
\hline Petroleum Oil & $\checkmark$ & & & & \\
\hline Polychlorinated Biphenyls & & & & & $\checkmark$ \\
\hline Sulfur Hexafluoride & & $\checkmark$ & & & \\
\hline Sulfuric acid & & & & & \\
\hline
\end{tabular}

\subsubsection{Clean Air Act (CAA)}

The PPPL was in compliance with the requirements of the CAA in 1990. PPPL has added a stack sampler to the TFTR facility for tritium releases, and this will meet NESHAPs radionuclide emission requirements for upcoming operations. The monitoring system currently exceeds existing requirements as current releases produce insignificant dose equivalent to any member of the public. The need for additional air emission permits is being investigated following a self-assessment by PPPL prior to the DOE Tiger Team assessment.

\subsubsection{Clean Water Act (CWA)}

The PPPL is in compliance with all requirements of the CWA. An assessment of groundwater has been undertaken as part of an effort following identified leaking underground storage tanks (USTs), which contained heating oil and vehicle fuel, and a soil gas survey of the entire site was completed, which identified potential solvent 
contamination. Groundwater wells were placed to assess the results of the soil gas survey, the UST issue, and NJPDES requirements.

\subsubsection{Endangered Species Act (ESA) and National Historic Preservation Act (NHPA)}

PPPL occupies 72 acres of the Forrestal Campus. Previous environmental statements and the current draft Environmental Assessments (EAs) for the BPX and TFTR have indicated that there are no endangered species or items relating th the NHPA on site.

\subsubsection{Executive Order (EO) 11988. "Floodplain Mianagement" and 11990. "Protection of Wetlands"}

The PPPL is in compliance with these EOs with the following unanswered questions. A dirt spoil pile from excavations for TFTR construction was placed in an area (1977-78) prior to wetlands determinations. While present wetlands determinations go around the spoil pile, there is some question on the need for a variance. Likewise, as a result of the Tiger Team assessment, it was determined that the PPPL HAZMAT facility has portions of the facility which are 4 inches below the 500-year floodplain and not protected, which may be a violation if the HAZMAT facility is considered a "critical" facility under 10 CFR 1022.

\subsubsection{Federal Insecticide. Fungicide, and Rodenticide Act (FIFRA)}

The use of herbicides, pesticides, and fertilizers is done by using certified subcontractors who meet all the requirements of FIFRA. The PPPL Plant Maintenance and Engineering (PM\&E) Division monitors this subcontract.

\subsubsection{National Environmental Policy Act (NEPA)}

The PPPL had two major NEPA documents under consideration in 1990. An Environmental Assessment (EA) for the BPX has undergone review, and an update to the TFTR 1975 environmental statement will be addressed with an EA for the proposed deuterium-tritium (D-T) modifications and operations. Numerous categorical exclusions (CXs) were applied for in accordance with DOE Secretary of Energy Notice (SEN) 15. 


\subsubsection{Resource Conservation and Recovery Act (RCRA)}

The Laboratory is in compliance with all terms and conditions required of a hazardous waste generator. PPPL is also in compliance with all requirements of the RCRA mandated Underground Storage Tank Program. See 3.1.3 above in relation to UST leaks.

\subsubsection{Safe Drinking Water Act (SWDA)}

The PPPL receives its drinking water from the Elizabethtown Water Company. While Elizabethtown is responsible for providing safe drinking water, PPPL does test incoming water. In addition, periodic testing for potential problems within the on-site drinking water distribution system is undertaken.

\subsubsection{Toxic Substance Control Act (TSCA)}

The PPPL is in compliance with all terms and conditions of TSCA by protecting human health and the environment by requiring that specific chemicals be controlled and regulations restricting their use be implemented. The last of PPPL's polychlorinated biphenyls (PCBs) transformers were removed from the site in 1990, and only 661 PCBregulated capacitors were left on site at the end of 1990.

\subsection{Current Issues and Actions}

The sole, ongoing, environmental compliance issue is the request for an adjudicatory hearing, by DOE, under the current New Jersey Pollutant Discharge and Elimination System (NJPDES) discharge to groundwater permit. The DOE is contesting the permit requirement that monitoring wells, with a monitoring program, be placed off-site on Princeton University property, at PPPL expense, when the University volunteered to cover these requirements. The DOE and PPPL are awaiting a hearing date and have, however, come into compliance with all permit mandated activities.

The PPPL was audited by a DOE Tiger Team between 2/11/91 and 3/12/91. PPPL had identified over $70 \%$ of the Tiger Team findings in its own self-assessment. There were 54 environmental findings, none of which represented situations that presented an immediate risk to public health or to the environment or that warranted an immediate cessation of operations. Of these findings, 38 were related to requirements of DOE orders, federal or 
state regulations, or PPPL directives or procedures. Sixteen (16) of the findings were related to best management practices. In addition, there were 166 safety and health concerns and 26 management concerns. An Action Plan was finalized in April 1991.

\subsection{Environmental Permits}

Environmental permits are maintained by PPPL (See Table 17). A discussion of the Environmental permits, by the applicable statutes, is listed below.

\subsubsection{Clean Air Act (CAA)}

The Laboratory maintains permits for 4 boiler vent stacks, 1 fuel oil storage tank vent, 1 diesel tank vent, 2 degreaser vents, and 2 emergency diesel generator exhaust stacks. All permits for these emissions are current, and all equipment under permit is operated within the permit specifications. Four underground storage tanks also were removed from the Laboratory in 1990, and registrations for the vent pipes for the gasoline tank, diesel tank, and one of the two fuel oil vent permits were terminated. As a result of a PPPL selfassessment prior to the Tiger Team, PPPL noted that some new permits may be required, not because of an emission limit trigger point, but because of process equipment used in the exhaust process. The Tiger Team addressed two additional sources which should be considered for the permitting process.

\subsubsection{Clean Water Act (CWA)}

The Laboratory maintains two permits under the New Jersey Pollution Discharge Elimination System (NJPDES) for discharges to surface water and groundwater. The permits are for a detention basin, which discharges to Bee Brook, and for non-point source infiltration of the detention basin waters to groundwater. An adjudicatory hearing was requested for the groundwater permit where several of the permit conditions are contested. In the interim, however, the permit is being maintained in full compliance including those conditions being contested in the requested hearing. The surface water permit has not been reissued by the NJDEP, and PPPL has been operating under its old permit since October 1989. The DOE/PAO has requested that storm water discharge points be added to the new permit when it is issued. 


\subsubsection{Resource Conservation and Recovery Act (RCRA)}

The PPPL maintains EPA Number (NJ1960011152) for RCRA generator status. The Laboratory is in compliance with all terms and conditions required of a "generator" status.

The PPPL maintains and is in compliance with permits for 4 USTs in operation on the site. Note that the UST program is a part of RCRA compliance activities.

\subsubsection{Miscellaneous Permits}

The PPPL maintains permits for medical waste generation as required by the NJDEP and for the purchase of potable water from the Elizabethtown Water Company. An agreement is in place with the New Jersey Water Authority until the year 2009 to draw water from the Delaware and Raritan canal system for cooling water needs and fire-fighting capabilities. PPPL is in compliance with all terms and conditions of these permits.

\subsection{January 1-April 1, 1991 Environmental Compliance Summary}

The first quarter of calendar year 1991 has produced the following changes from the 1990 summary:

- An NJPDES discharge monitoring sampling point was not collected by the PPPL subcontract vendor in January 1991. This noncompliance was reported to the NJDEP, and a new procedure was set up with the vendor to ensure that this type of an oversight would not be repeated.

- The initial data from the groundwater assessment program was received. The initial results are not as severe as were expected from the 1990 soil gas survey. The data has been sent to the NJDEP with recommendations to do further sampling and to fill in the excavations from the UST soil removal project. No further action can be taken without NJDEP guidance and approval.

- The DOE Tiger Team audited ES\&H programs at PPPL from February 11 through March 12, 1991. While no significant findings were identified in relation to environmental impacts and compliance issues, best management practices on the need for additional permits, sampling procedures, and timely report submittals were identified. The number of 
findings are noted in Section 3.2, above. An Action Plan has addressed all Tiger Team concerns.

\subsection{ENVIRONMENTAL PROGRAM INFORMATION}

The monitoring-program implementation has followed a phased approach commensurate with the potential hazards and the needs of an expanding program. Nonradioactive waterpollutant monitoring has been conducted for many years. A more extensive program was begun in 1979, which included eight surface water-sampling points (four on-site and four off-site). In addition, four groundwater sites (two former drinking water wells and two wells near the TFTR liquid effluent-collection tanks), along with the potable water-supply, were monitored through November 1989. In November 1989, two former wells were dropped from the program, and seven new wells were added as part of the New Jersey Pollutant Discharge and Elimination System (NJPDES) permit requirements. Current NJPDES permit requirements include one detention basin discharge point for the surface water permit, two influent surface water points for the groundwater permit, and seven (7) groundwater wells.

Monitoring for sources of potential radiological exposures is extensive. Real-time prompt gamma/neutron environmental monitoring began on the TFTR site in 1981 to establish haselines prior to machine operation. Four monitoring stations are located at the TFTR facility boundary (formally called the exclusion zone boundary (EZB)). Neutron monitors were added at these locations at the end of CY84. Passive tritium monitors were added in CY87. Radiological-water samples are being collected at the same locations as the nonradioactive-sample points (see Figs. 20 and 21). Soil and biota samples are also being analyzed for tritium baselines. One off-site baseline tritium air monitor was added in CY89, and six others are planned for FY91-92.

\subsection{Assessment of Radiation Dose to the Public}

The PPPL is located in the metropolitan region between New York City and Philadelphia. Census data indicate that approximately 16 million people live within $80 \mathrm{~km}$ (50 miles) of the site and approximately 212,000 within $16 \mathrm{~km}$ (10 miles) of PPPL. The detailed distribution of population as a function of distance is given in Tables 4-16. Because of ever-increasing commercial growth in this area, a demographic update was planned for 
TFTR but was completed as a requirement for the BPX Environmental Assessment [Be87a]. Also, a radiological assessment was completed for BPX [Mc89].

The overall, integrated, effective-dose equivalent from all sources (excluding natural background) to a hypothetical individual residing at the nearest business was calculated to be 0.018 mrem $(0.18 \mu \mathrm{Sv})$ for CY90 [Gi91] using the USEPA COMPLY code [EPA89]. This effective dose equivalent was calculated after postulating that all the tritium produced during TFTR D-D operations and Argon-41 produced from air activation was released to the environment. Detailed person-rem calculations for the surrounding population were not performed, because the value would be insignificant in comparison to the approximately 100 mrem ( $1 \mathrm{mSv}$ ) each individual receives from the natural background, exclusive of radon, in New Jersey. However, scaling to calculated data was done and indicates a value of only $5 \times 10^{-2}$ person-rem $\left(5 \times 10^{-4}\right.$ person-Sievert) out to $80 \mathrm{~km}$ (see Table 18 ).

\subsection{Assessment of Nonradioactive Pollutants}

There were no activities during CY90 that created problems with respect to nonradioactive pollutants. The chronic oil spill from underground tanks, which present some potential minor environmental impacts, are being addressed and are discussed below.

Polychlorinated biphenyls (PCB's) and other toxic materials continue to be disposed of in accordance with EPA requirements. Herbicides, pesticides, and fertilizers were used in very limited quantities.

\subsection{Pollution Prevention and Waste Minimization}

The PPPL has a pollution prevention and waste minimization plan as required by DOE Order 5400.1 [DOE90b]. A survey was completed in June 1990 [CEE90] and indicated that PPPL had already taken many appropriate steps in waste minimization by product substitution and volume reduction. In FY91-92, a more detailed program will be undertaken to further the testing and use of non-hazardous products such as "TPC Solvent" and "Citrikleen" in place of "Inhibisol," acetone, and alcohol. Further investigation of possible means for source reduction will begin with waste-stream identification. 


\subsection{Regulations and Safety Criteria}

The appropriate Radiation Protection Standard for penetrating radiation was taken from DOE Order 5480.11. Specific criteria for implementing these standards are contained in PPPL Environment, Safety, and Health Directive (ESHD) 5008, Section 10, and specifically for TFTR in Operational Safety Requirements, in particular, OSR/TFTR/0-2FC. The concentration guides, used in the analyses of surface water samples for radioactivity, were taken from DOE Order 5400.5, Chapter III. The derived concentration guides for airbome activity are taken from the same DOE Order. Tritium, for example, is listed as $1 \times 10^{-7} \mu \mathrm{Ci} / \mathrm{ml}$.

Air and Water Pollution Standards for nonradioactive pollutants were taken from the New Jersey Administrative Code (NJAC), Department of Environmental Protection 7:27-1, et seq, 7:14-1, et seq, and 7:14A-1, et seq, respectively. The appropriate regulations for PCBs and hazardous waste are found in the U.S. Code of Federal Regulations, 40 CFR 761 and 40 CFR 260-265, respectively.

\subsection{Euture Program Expansion}

\subsubsection{Meteorological}

A meteorological tower was installed in November 1983. Data from this system are being used in updating dose calculations for the updated version of the TFTR FSAR. Data were also evaluated by the BPX project in relation to siting the BPX at PPPL. Several doseassessment codes are being employed by PPPL to utilize the data from this tower in the calculation of projected doses. These codes include the required DOE standard AIRDOSEPA, as well as PAVAN, XOQDOQ, and an Ontario Hydro version of TRITMOD. Future plans include considerations of hooking up a real-time output of the meteorological data. Instrumentation was added at $10 \mathrm{~m}$ in 1990 to collect wind speed and direction in addition to the present instruments at 30 and $60 \mathrm{~m}$.

\subsubsection{Water Quality}

The initial phases of a groundwater monitoring program began in CY85. Analysis of water samples from two D-site wells was added to the moritoring program in CY86 utilizing USGS data. PPPL took over the water quality program on these two wells in December 
1987. New wells were added in response to new state requirements for a groundwater discharge permit and as a result of UST spills and soil gas testing (see below). This expanded groundwater program will help to more fully understand our regional groundwater flow, surrounding area (off-site) groundwater contamination, and in anticipation of requirements for BPX.

\subsubsection{Radioactive Effluents}

\subsubsection{Air. Gaseous and Particulates}

Based on collected data, a decision was made in CY84 to limit the specific air and particulate real-time monitors at the EZB to a beta detector only. Particulate air sampling has been accomplished as a best management practice and not because of a particular source term. This sampling may be discontinued because of a DOE Tiger Team finding to change from our present low-volume air sampling to a high-volume air sampler.

Environmental tritium monitors tested in CY86 were deployed at the EZB in CY87. These were to be extended to off-site locations in CY88 but were delayed because of budget reductions at the end of the year. A baseline station was established off-site during 1989 at an 8-mile distance in the northwesterly direction. Six new stations are being planned offsite within $1 \mathrm{~km}$ of the TFTR exhaust stack.

\subsubsection{Off-Site Radiological Water and Biota Monitoring}

An off-site grab sample water-analysis program is well established. Whether more sampling points will be added in the future depends on reevaluation of the program, which is done annually. Soil and vegetation sampling is under way and will continue.

\subsubsection{Nonradioactive Effluents}

Air-effluent standards will continue to be met by following the guidelines of the NJDEP. Any potential toxic materials will be monitored and disposed of in accordance with applicable regulations and accepted guidelines. More permits for on-site discharge points may be requested as indicated by a PPPL self-assessment and 1991 Tiger Team assessment. 


\subsection{ENVIRONMENTAL RADIOLOGICAL PROGRAM INFORMATION}

\subsection{Penerrating Radiation}

Operation of the Princeton Beta Experiment-Modification (PBX-M) results in the production of some penetrating radiation (primarily bremsstrahlung $X$-rays and neutrons). Because the PBX-M has no roof shield, skyshine radiation (primarily neutron) is seen at the TFTR EZB site monitoring stations. The shielding installed for the PBX-M machine has kept the total dose equivalents in occupied areas below occupational-exposure guidelines. Skyshine radiation from the neutron production by PBX-M generally adds less than $1 \mathrm{mrem}(0.01 \mathrm{mSv})$ to the D-site environs [St91]. PBX-M did not operate in 1990 and thus had no impacts to the environment.

It is stated Laboratory policy that when occupational exposures have the potential to exceed $1,000 \mathrm{mrem} / \mathrm{y}(10 \mathrm{mSv} / \mathrm{y})$, the appropriate project manager must petition the PPPL Executive Safety Board (ESB) for an exemption. This value is $20 \%$ of the DOE legal limit for occupational exposure. In addition, the Laboratory applies the DOE ALARA (as low as reasonably achievable) policy to all its operations. This philosophy for control of occupational exposure means that environmental radiation levels, as a result of experimental device operation, are also very low . nd acceptable. To illustrate this point, a 1,000 mrem dose equivalent from direct radiation at the outer TFTR test cell wall will result in less than $10 \mathrm{mrem}(0.1 \mathrm{mSv} / \mathrm{y})$ at the facility boundary. Actual environmental measurements of the TFTR facility boundary are shown in Figures 22 and 23. Figure 22 indicates gamma background readings which range between 170-240 $\mu$ R/day. Figure 23 indicates a neutron measured value of between 10-14 $\mu \mathrm{rem} /$ day.

The design objective for TFTR is to stay below $10 \mathrm{mrem} / \mathrm{y}(0.1 \mathrm{mSv} / \mathrm{y})$ above natural background from all sources of radiation at the PPPL site boundary. The TFTR, like other tokamaks, produces bremsstrahlun 6 radiation from the electrons striking internal hardware at the end of a pulse. These $\mathrm{X}$ rays, in the range of 0 to $20 \mathrm{MeV}$, also produce photoneutrons.

Injection of deuterium neutral beams began at the end of CY84. With these D-D runs, the neutron fluxes have increased each year as the neutral-beam heating power has increased. In 1985, the neutron production was on the order of $5 \times 10^{16}$ for the entire year. This number increased to $2.4 \times 10^{18}$ in CY86, to $3 \times 10^{18}$ during a short run year in CY87, 
and to $9.04 \times 10^{18}$ in CY88, and because of limited operation (also more plasma transport experiments and less supershots), the number reduced to $6.4 \times 10^{18}$ in CY89. In 1990, the neutron production was $2.3 \times 10^{19}$ [Ja90b]. Additional shielding was added to the TFTR test cell walls in the middle of CY85. This added shielding has prevented the addition of any significant penetrating radiation to the environs due to TFTR operation. Radiation levels (mrem) were recorded for some pulses outside the test cell, with the total dose equivalent at the closest off-site receptor calculated by the COMPLY Code to be 0.018 mrem $(0.18 \mu \mathrm{S})$ for CY90 [Gi91].

The TFTR real-time site boundary monitors are Reuter-Stokes Sentri 1011 pressurized ionization chambers and ${ }^{3} \mathrm{He}$-moderated neutron detectors. The electronics in the ionization chambers were modified to allow the integration of any prompt radiation resulting from a TFTR machine pulse which may be above natural background. These data are stored and processed using the Central Instrumentation. Control, and Data Acquisition (CICADA) computer system. Four of these monitoring stations are placed at the TFTR facility boundary (see Fig. 20). In addition, eight ionization chambers of lower sensitivity, paired with neutron monitors, are located nearer the TFTR device (four outside the test cell wall, three in the basement, and one on the roof). These eight detector locations are for personnel safety and are not considered environmental detectors per se. However, data collected from them are used to help correlate the environmental measurements. Besides the moderated ${ }^{3} \mathrm{He}$ and fission neutron detectors, Bonner-type-moderated LiI (Eu) detectors were also used for monitoring neutron dose equivalents at various locations throughout the TFTR facility. Monitors are calibrated and traceable to the National Institute for Standards and Technology (NIST)—formerly the National Bureau of Standards (NBS).

\subsection{Special Radiation Surveys}

\subsubsection{EG\&G Radiation Survey (Flyover)}

In August 1980, EG\&G Idaho, Inc., under DOE contract, conducted an aerial-radiological survey of PPPL and surrounding areas [St81]. The detection system consisted of 20 sodium iodide detectors, a multichannel analyzer, and a magnetic-tape recording system. The nominal gamma-ray exposure rate range observed was 8 to $10 \mu \mathrm{R} / \mathrm{h}$. Detected radioisotopes were consistent with normal background emitters. Since conditions have not changed at C-or D-sites since 1980 , there is no need at this time to repeat the survey. 


\subsubsection{National Oceanic and Atmospheric Administration (NOAA)}

The Air Resources Laboratories Field Research Division (ARLFRD) of the National Oceanic and Atmospheric Administration (NOAA), Idaho Falls, Idaho, conducted atmospheric dispersion studies using tracer gases from July through September 1988. This group specializes in air quality by doing research on the physics of the lower atmosphere with emphasis on the processes contributing to atmospheric transport, dispersion, and deposition and on the development of numerical models using the results of this research. This study is being used to understand and predict human influence on the environment, especially with regard to the atmospheric transport and diffusion of toxic effluents [St89].

While Nuclear Regulatory Commission (NRC) standard-approved gaussian models, which are normally used to calculate atmospheric diffusion to support radiological dose assessments, are appropriate for sites in open terrain, they underestimate atmospheric dilution for sites like PPPL where potential sources of release are located in the midst of a complex of buildings. These buildings generate mechanical turbulence which increases atmospheric dilution and reduces dose. The field tests conducted by NOAA were performed to cbtain a more realistic empirical description of actual atmospheric diffusion at PPPL in relation to TFTR and the future BPX. The results indicate a factor of approximately 16 less potential dose equivalent than that calculated by using NRC gaussian models. The EPA was petitioned by DOE/PAO to utilize this real-time data for use in calculations using AIRDOS-EPA, a required code for annual NESHAPs calculations. Indications are that the EPA will approve this request in 1991. In 1990, DOE authorized the use of the EPA COMPLY code for NESHAPs calculations.

\subsubsection{LLNL Seismic Study}

The PPPL Environment, Safety, and Fealth Division (ESHD) initiated and provided technical direction for a contract with Lawrence Livermore National Laboratory (LLNL) to perform a seismic hazard analysis for the PPPL site in 1989. This study, which was based on the latest methodology accepted by the Nuclear Reguiatory Commission (NRC) for seismic analysis of Eastern U.S. nuclear power plants, indicated that the earthquake parameters applied to the TFTR project met and exceeded the current applicable DOE requirements [Sa89]. 


\subsubsection{EML Radiation Measurements}

A radiation measurement survey was accomplished by the DOE Environmental Measurements Laboratory (EML) in 1990. The measurements used high sensitivity instruments and confirmed ES\&H Division Health Physics measurements, which indicate that the neutron dose equivalents during operational periods in occupied areas and at the TFTR facility boundary are much less than the original conservative code calculations. The final results are expected to be published in May 1991.

\subsection{Airbome Radioactivity}

Radioactivation of air and the release of tritium in measurable concentrations (by EPA accepted measurement criteria) are not expected until TFTR D-T operations. A silica gel environmental tritium monitor was tested in 1986 and was placed in operation during the summer of 1987 . With experience gained in a Canadian tritium release modeling experiment and in the field at PPPL, the monitor is now using molecular sieve in place of silica gel [Gr88b]. Based on D-D neutron production during CY90, it is estimated that a maximum of approximately $1.1 \mathrm{Ci}(41.3 \mathrm{GBq})$ of tritium could have been added to the environs outside the TFTR facility. Tritium was detected in TFTR effluent samples by a DATS. However, the sampling system that was in place for much of 1990 was not sufficient to quantify tritium emissions because most of the tritium was released through a vacuum line. Therefore, 1990 tritium emissions were calculated based on the number of neutrons generated. Our actual experience with the absorption and adsorption of tritium in TFTR vessel-graphite tiles in 1987 indicates that some tritium produced over the last few years by $D-D$ reactions has been retained in the tiles [St $88 \mathrm{~b}$ ]. The tiles retain approximately one-third of the tritium produce during $D$ - $D$ reactions. The projected dose equivalent at the nearest business from $1.1 \mathrm{Ci}$ of tritium and $1.9 \mathrm{Ci}$ of ${ }^{41} \mathrm{Ar}$ was $18 \mu \mathrm{rem}(180 \mathrm{nSv})$, based on the use of the COMPLY Code [EPA89]. When actual NOAA $\chi / Q$ values are used, the calculated values are even smaller, approximately $2.9 \mu \mathrm{rem}$ ( $29 \mathrm{nSv}$ ) (see Table 40). An upgraded stack sampling system installed in 1990 will provide measured tritium emission for 1991 for any tritium concentrations exceeding the minimal detectable levels of the DATS. Evaluations of proper laminar flow and mixing for acceptable monitoring data are now under discussion with the EPA. An off-site monitor has shown some variation in background ambient levels, which are not attributable to PPPL operations. Measurements at the TFTR fence line have shown ambient levels in the range of 1 to $5 \mathrm{pCi} / \mathrm{m}^{3}$ of elemental and oxide tritium concentrations (Figs. $24 \& 25$ ). These measurements were 
made with the DATS [Gr88b]. Both Figures 24 and 25 indicate a higher reading, especially at trailer position \#1, during the first 20 weeks of the year. The reason for these increased readings was traced to the hydrogen used in the carrier gas of the DATS system. Whereas PPPL's carrier gas is specified as a petroleum by-product procurement, which implies deep wells and therefore little, if any, tritium contamination, the particular carrier gas was obtained from surface water electrolysis, which would have surface water tritium levels recovered in the process.

Argon-41 is a potential air activation product from neutrons produced from D-D reactions. Its maximum production in 1990 was $1.9 \mathrm{Ci}(70.3 \mathrm{GBq})$, with an estimated dose equivalent at the nearest off-site business of 2.1 :Lrem $(21 \mathrm{nSv})$ using NOAA $\chi / \mathrm{Q}$ data (see Table 18).

In November 1983, a three-level, 60 meter tower was installed for gathering meteorological data. Seven years' worth of data have now been collected. The wind-rose data for the first six years of tower operation are shown in Figs. 3 and 4. Analysis indicates that the site is dominated by neutral to moderately stable conditions, with moderately unstable to extremely unstable conditions occurring less than a few percent of the time. Average surface winds are about $2.1 \mathrm{~m} / \mathrm{s}$ and rise to about $4.1 \mathrm{~m} / \mathrm{s}$ at $60 \mathrm{~m}$ [Ko86a]. Based on data from this tower and NOAA tracer gas release-modeling, $\chi / Q$ values will be recalculated for the updated TFTR FSAR before D-T operations. The data were also checked for consistency by the Idaho National Engineering Laboratory (INEL) in their preparation of an Environmental Assessment (EA) for the BPX project. Data collection at $10 \mathrm{~m}$ were added in 1990 .

\subsection{Waterborne Radioactivity}

\subsubsection{Surface Water}

Surface water samples at eight locations (four on-site and four off-site) have been analyzed for tritium and photon emitters. Five of these locations have been monitored since CY82. Downstream sampling occurs after the mixing of effluent and ambient water is complete. Locations are indicated on Figs. 20, 21, and 31.

Sample analysis has shown no unusual background radionuclides. Tritium analysis by liquid scintillation methods has shown tritium values to be less than $100 \mathrm{pCi} /$ liter ( 3.7 
$\mathrm{Bq} /$ iter) on all samples analyzed to date (Fig. 26). Tritium enrichment procedures are used on some samples to provide increased sensitivities. Rain water samples collected and analyzed ranged from less than 14 to $94 \mathrm{pCi} /$ liter (see Table 19 and Fig. 27), which was similar to the 1985 range of 45 to $160 \mathrm{pCi} /$ iter, the 1986 range of 40 to $140 \mathrm{pCi} /$ liter, the 1987 range of 26 to $144 \mathrm{pCi} /$ liter, the 1988 range of 34 to $105 \mathrm{pCi} /$ /iter, and the 1989 range of 7 to $90 \mathrm{pCi} /$ liter. The reason for this variation can be explained as follows: HT and HTO, mainly from prior world-wide, above-ground weapons tests, go into the stratosphere and are returned to the troposphere by turbulence. The HT slowly converts to HTO. Furthermore, the residence time in the atmosphere is on the order of years. There is a variation of HTO in rain water as the stratosphere slowly turns over, with very little exchange between the stratosphere and troposphere in the winter months [Os88]. The peak values are slowly decreasing over the years, which is consistent with the decay of tritium with no large inventories being added.

In 1988, PPPL initiated the collection of precipitation and monitored levels starting with the second quarter. While 1988 was a dry year, 1989 and 1990 were relatively wet years with over 55 inches $(140 \mathrm{~cm})$ of precipitation in 1989 and 50.3 inches $(128 \mathrm{~cm})$ of precipitation in 1990 (see Fig. 28 and Table .?0) [Ch91].

\subsubsection{Groundwater}

Seven existing on-site wells-W4, W5, D11, and D12 on C-site (Fig. 20), and TW1, TW3, and TW10 on D-site-were sampled (see Table 21). As a part of continuing efforts to characterize the site, a more comprehensive groundwater program was initiated in June 1985 through the USGS. This program entailed the drilling of several monitoring wells on the TFTR site in order to help profile the groundwater system. The final USGS survey report was issued in 1987 [Le87]. This report indicates a cone of depression created by the TFTR sump system (Fig. $29 \& 30$ ). The samples collected from two of the wells (TW1 and TW10 at D-site) were analyzed for tritium by PPPL. The sample results were consistent with previous testing accomplished by PPPL and the USGS and indicated tritium levels less than $100 \mathrm{pCi} /$ liter $(3.7 \mathrm{~Bq} / \mathrm{hiter})$. These values are consistent with surface-water measurements. The results for 1990 are also less than $100 \mathrm{pCi} /$ iter $(3.7$ $\mathrm{B}(\mathrm{y} / \mathrm{iter})$. 


\subsubsection{Drinking Water}

Potable water is supplied by the public utility, Elizabethtown Water Co. In April 1984, a sampling point at the input to PPPL was established (E1 location, Fig. 20) to provide baseline data for water coming onto the site. Radiological analysis has included gamma spectroscopy and tritium-level determination. Tritium levels are similar to surface and well waters with measurements indicating less than $100 \mathrm{pCi} /$ iter $(3.7 \mathrm{~Bq} /$ liter); also, only naturally occurring gamma-emitting radioisotopes have been detected. Radium and radon levels have not been measured in the potable water system by PPPL.

\section{$5.5 \quad$ Foodstuffs}

Because there are so few dairy farms in this area, milk is not a viable analysis medium around the site. Also, the fish population is very scarce to nonexistent in Ditch 5 and Bee Brook, which carry the runoff from the site. The DOE agreed in 1986 that a substitute of vegetables and other biota from the surrounding area can be used for reference data. A corn sample taken on September 18, 1990, indicated a value of $61 \mathrm{pCi} / \mathrm{L}$. Distillation techniques were unsuccessful for strawberries, peas, and pumpkins [Gi91]. The measured letel is indicative of tritum in the environment (see water results).

\subsection{Soil, Grass and Vegetation}

Off-site sampling locations were established in late 1985 (see Fig. 31). In 1991, some sampling points will be relocated because of construction in the area and also to be near proposed air-monitoring stations. Soil and grass samples collected on-site and off-site in 1990 indicated tritium levels below 100 pCi/liter (3.7 Bq/liter) (see Fig. 32 and Table 22). Sample location S14 was not done in 1990 due to overpass and road construction. Laboratory techniques for doing these analyses were perfected in CY84 [Gr85], and the techniques are documented in the Radiological Environmental Monitoring Laboratory Handbook [REML90]. These baselines are being established because surface soils and vegetation are among the best indicators of tritium deposition after a release [Jo74], [Mu77], [Mu82], [Mu90]. The present, measured concentrations are consistent with those of tritium in the environment. 


\subsection{ENVIRONMENTAL NON-RADIOLOGICAL PROGRAM INFORMATION \\ 6.1. Airborne Effluents [Ki91]}

The PPPL has a New Jersey Department of Environmental Protection (NJDEP) permit for its four C-site boilers and one fuel tank vent. The five permit certificates, numbered 061295 through 061299, were renewed in 1987 and will next expire on March 31, 1992. New air permits applied for and received include the TFTR Mockup Building degreaser, the Field Coil and Power Conversion (FCPC) building degreaser, the TFTR emergency generator diesel engine, the C-site emergency generator diesel engine, and a 15,000 gallon diesel tank vent (E\#8).

Measurements of actual boiler emissions are not required. Emissions were initially calculated using formulas supplied by the NJDEP [Ki88]. These formulas are based soiely on the percent sulfur and the number of gallons of oil burned per hour in each boiler. In the last quarter of CY87, PPPL purchased an ENERAC POCKET 50 combustionefficiency analyzer. This device indicates boiler efficiency, oxygen content, flue-gas temperature, and carbon-dioxide content of the stack gas for both oil and natural-gas fuels. This information is recorded and entered into a log book by the boiler operators. This is done to optimize boiler efficiency and to reduce fuel costs in accordance with DOE Order $4330.2 \mathrm{C}$ [DOE88b].

\subsection{Water Utilization [Ki91]}

\subsubsection{Drinking Water}

Potable water is supplied by the public utility, Elizabethtown Water Co. The PPPL used approximately 24.1 million gallons in CY90. This is a significant reduction from years prior to 1987 because of the changeover to Delawware \& Raritan (D\&R) Canal water for the cooling-water systems. Water quality analysis at the input to PPPL was initiated in CY84 to measure nonradioactive pollutants (Table 29, E-1 location), as well as to measure potential radioactive pollutants exclusive of radium or radon. 


\subsubsection{Process (nonpotable) Water}

Nonpotable water is pumped by PPPL from the D\&R Canal as authorized by a permit agreement with the New Jersey Water Supply Authority. The present agreement gives PPPL the right to draw up to one million gallons of water per day for process and firefighting purposes for the period beginning July 1984 and ending on June 30, 2009. Renewal is expected at the end of the present contract. Filtration to remove suspended solids is the primary treatment. In 1986. a multimedia sand filter was installed to allow the source of the D-site cooling tower make-up water to be changed from potable water to process-water supply. The PPPL used approximately 49.3 million gallons of canal water during CY90. The sampling point $(\mathrm{C}-1)$ was established to provide baseline data for process water coming on-site. Table 25 indicates results of water quality analysis at the canal.

\subsubsection{Storm Water}

Storm water, which includes cooling tower and boiler blowdown, is discharged into surface waters and is governed at C- and D-sites by NPDES Permit No. NJ0023922 (effective date November 1,1984-xpiration date October 31,1989). This permit is still in effect while NJDEP reviews the new application request. All process water and most runoff water from C- and D-sites now pass through a detention basin. Approximately 7.3 million gallons discharged through the detention basin in CY90. Discharge points which do not run into the detention basin are included in the surface water renewal permit application. Upgrades to the detention basin, including an oil-spill detection and alarm system, were completed in 1986. As a result of minor problems following the transformeroil leak in 1988 [St88d] and the 1988 DOE Environmental Survey (see 6.7.2), another analysis of this system determined that the best long-term, best management practice, environmental solution is to line the detention basin and to find more reliable oil sensors. This project is expected to be funded in CY91. Quarterly water-chemistry reports, compiled from the data of Table 22, were submitted to the state of New Jersey in 1990 in accordance with NJDEP requirements. The PPPL was well within the allowable limits for all testing parameters during CY90.

Cooling-water treatment was changed from a chromate-based corrosion inhibitor to a nonchromate inhibitor in June 1983. Water analyses downstream and groundwater tests (see Tables 23-46) have not indicated concentrations of any environmental pollutants, in 
general, above applicable codes, regulations, or standards. One cooling tower discharges to the storm water and the second to the sanitary sewers. The Stony Brook Sewage Authority has requested that the second cooling tower also discharge to the surface water. This change is authorized under our current permits per discussions with the NJDEP. The changeover is expected in CY91. Two shallow wells (D11 and D12), next to the detention basin, indicated some lead in CY89. Subsequent monitoring of these wells has not shown any detectable lead levels. After the application for the the groundwater permit, which was filed in 1986, the NJDEP proposed the addition of monitoring wells around the detention basin and three wells off of DOE-leased property. While DOE has requested a hearing on the off-site well aspects of the permit requirements, PPPL came into compliance with the existing permit requirements in November 1989. Monitoring of the off-site wells (MW14, 15, and 16-see Fig. 31) has not shown any contaminants and, therefore, closure of the wells or turnover to Princeton University will be requested of the NJDEP in 1991.

An updated Spill Prevention Control and Countermeasures (SPCC) Plan was received from an environmental consultant in January 1985 and is currently scheduled for an upgrade completion in early CY91. The final update was delayed until after the EPA issued the Final Regulations for Underground Storage Tanks (UST). With the experience of the underground storage tank leakage, PPPL will eliminate all of its underground tanks by CY92.

\subsubsection{Sanitary Sewage}

Sanitary sewage is discharged to the publicly-owned treatment works operated by South Brunswick Township at the Stony Brook Regional Authority. Flow rates are measured by the PPPL sanitary-sewage metering station and indicated a total volume discharge of approximately 19 million gallons in CY90. Sampling of PPPL discharges, performed by the publicly-owned treatment works in the past, had determined that pretreatment is unnecessary. Therefore, PPPL is in compliance with the EPA Pretreatment Standard, 40 CFR Part 403. However, new sampling requirements are expected in CY91. When these regulations are promulgated, PPPL will implement the requirements.

\subsubsection{Surface Water}

Surface water is monitored for potential nonradioactive pollutants both on-site and at surface-water discharge pathways (upstream and downstream) off-site in addition to the 
one location (D2) required by the NJPDES permit (See Figs. 20, 21, and 31, and Tables 23-32). These extra sampling locations are not required by regulations, but are a part of a PPPL best management practice.

\section{$6.3 \quad$ Spills}

Several spills were recorded in CY90. Those which posed a potential threat to the environment were reported to the NJDEP in accordance with their reporting requirements. A chromium sand pile was discovered, which was a result of the former decommissioning of a sand filter for the C-site cooling tower (NJDEP ID \#90-03-23-1551) [Tu90]. Sampling of the sand and discussions with the NJDEP determined that the sand could be classified as "non-RCRA hazardous." A second spill (NJDEP ID \#90-08-09-1320), which was entirely internal to a room within a building, involved the mixing of a few quarts of nitric acid with acetone. Because of the potential explosive nature, the incident was reported to the NJDEP as a spill [S190]. A third spill was identified during the annual leak tightness test for USTs. A 1,000 gallon diesel fuel tank was found to have a leak in a connection in a supply line. The spill was reported (NJDEP ID \#90-10-22-1141), a well was emplaced, and a discharge investigation corrective action report (DICAR) was generated. It is expected that this issue will be closed in CY91. In addition, this UST will be removed as part of the PPPL program to remove all of its USTs and replace them, where needed, with above-ground tanks. A fourth spill involved the leaking of hydraulic oil from the pumping system for a vertical bore milling machine. Soil was removed and a report was generated [Fi91]. Subsequently, the NJDEP has requested the emplacement of a well next to the excavated area for groundwater monitoring. Two wells within approximately $60 \mathrm{~m}$ of the spill were deemed to be too far removed from the spill site by NJDEP. Other miscellaneous spills within facilities did not require notification of the NJDEP or the National Response Center. All spills are responded to immediately by an inhouse Emergency Services Unit (ESU), who acts as first responders. Outside consultants are under contract to provide clean-up services if it is required. Because of the prompt internal response and vigilance by employees, the 1990 spills resulted in no significant impacts to the environment.

\subsection{Herbicides, Fertilizer, and Pesticides [Ra91]}

During CY90, the use of herbicides, pesticides, and fertilizers was managed by PPPL Plant Maintenance and Engineering utilizing an outside contractor. These materials are applied in 
accordance with state and federal regulations. Herbicides are applied by a certified applicator. Table 47 lists the quantities applied during CY90.

\subsection{Polychlorinated Biphenyls (PCBs)}

Beginning in CY82, PPPL started a program to dispose of PCB-containing capacitors, transformers, and other similarly contaminated items. During the early phases of the program, all stored items in a GSA (General Services Administration) Warehouse in Belle Mead, New Jersey, were discarded through approved disposal contractors. Remaining PCB items were labeled, as required by EPA regulations, and an inventory, inspection, and status report program was initiated. At the beginning of CY84, PPPL still had 15 PCB transformers and 6,005 large capacitors containing PCBs. In CY84, 375 large and 54 small PCB capacitors were disposed of, as well as the oil and containers of two transformers. In 1985, an additional 1,330 large capacitors and 22 small capacitors were removed properly from the site. In 1986, a few small capacitors but no transformers were discarded. In 1987, two transformers containing 700 gallons of PCB fluid were disposed. In addition, 1,145 gallons of less than 500 ppm PCB fluid were generated from reworked and reclassification of six $\mathrm{PCB}$ transformers to non-PCB transformers, and 391 capacitors were disposed. In 1988, 1,696 capacitors and four small transformers were removed. In 1989, 273 capacitors were disposed while an additional 1,108 were removed from service. Eleven transformers were disposed along with one contaminated transformer containing 113 gallons of PCB fluid (186 ppm). In 1990, the remaining PCB transformers were disposed, leaving only one contaminated transformer (>50 ppm) on site. This transformer will become a noncontaminated transformer in 1991. At the end of 1990, PPPL was left with only 661 large regulated capacitors. PCB capacitors are being disposed as they are taken out of service. Disposal records are listed in the Annual Hazardous Waste Generators Report [La91].

\subsection{Hazardous Wastes}

Responsibility for this program rests with the PPPL Hazardous Material Manager under the Materiel Control Office. A facility was set up in CY82 for temporary storage of hazardous materials. A new area was built in 1986. This facility has concrete floors with containment walls, fire alarms, security surveillance, fire extinguishers, an eye-wash station, an emergency shower, and telephones. Improvements to the facility, following experience gained from operational needs, were made in CY88. A concern in 1990 was the flaking of 
the epoxy sealant used on the outside asphalt loading and unloading area. A question brought out during the DOE Tiger Team assessment indicates a resolution is needed on some areas of the facility being within the 500-year flood plain when the definition of "critical facility" per 10 CFR 1022 is applied [CFR90]. This issue will be addressed in CY91.

The Hazardous Waste Generator Annual Report (EPA ID number NJ1960011152) has been submitted for 1990 in accordance with EPA requirements [La91]. During 1990, $6,731,436$ pounds of solid materials and 12,970 gallons of liquid waste were disposed at EPA-certified treatment, storage, and disposal facilities. These totals included 380,463 pounds of PCBs (oil plus containers). These numbers reflect actual waste, plus containers and packing materials. It should be noted that a significant fraction of the waste was oilcontaminated soil from oil-spill cleanups $(6,336,000$ pounds). Outside of oil contaminated soil and PCB disposal, less than 15,000 pounds of other hazardous waste (including containers) was shipped for disposal.

\subsection{Special Non-Radiological Program Surveys}

\subsubsection{U.S. Geological Survey Study}

A groundwater study by the U.S. Geological Survey (USGS) began in 1985 and was completed in 1987 [Le87]. While this special study was predicated on a spill of tritium from the liquid effluent collection tanks (LECTs), it more appropriately addresses the general ground water quality and flow patterns in the region near the TFTR facility. Figure 29 shows the potentiometric surface of the bedrock aquifer from this report. The report also indicated that the sumps under the TFTR complex create a cone of depression (Fig. 30). These data are being used in conjunction with the present groundwater studies. The USGS also presented PPPL some data developed in an unrelated study on naturally occurring radioactivity in the ground. Uranium-enriched rocks can be a source of radioactivity in groundwater [Sz87, $\mathrm{Za87}]$.

\subsubsection{DQE/HQ Environmental Survey}

A comprehensive environmental survey was conducted by DOE/HQ utilizing outside subcontractors during the month of June 1988. This survey was a part of a DOE program which looked at 45 of their facilities. No significant environmental impact findings were 
noted at PPPL during this survey. A plan of action for findings was forwarded to DOE, and except for long-lead time items, the findings have been closed out. Soil sampling for petroleum hydrocarbons from former spills and for chromium in soils from previous use in cooling towers was accomplished in November 1988 [DOE88a]. Data from this sampling effort have not shown any significant contamination requiring any follow-up action by PPPL.

\subsubsection{Soil Gas Survey}

As a need to further characterize potential contamination on the site based on the UST spill results and low-levels of solvent contamination seen in four monitoring wells (TW-1, TW3, TW-10, and D-11), plus requirements of the PPPL NJPDES permit, a Petrex passive soil gas test was conducted during the months of April-May 1990 over the entire site [Ne90]. The PPPL decided to take a proactive approach to look for any potentially unknown chemical contamination over the entire site.

The data were generated by conducting a survey which produced identification for tetrachloroethene (PCE), trichloroethene (TCE), aromatic hydrocarbons compounds (AHC), and trichloroethane (TCA). The survey indicated that localized anomalies had been detected and delineated at five locations. They were (1) north and east of the excavation pit for the former UST locations including the eastern half of the Plant Maintenance and Engineering Building and the TFTR Cooling Tower Buildings (PCE,TCE,AHC, and TCA); (2) through the eastern half of the Receiving Warehouse Building (PCE, TCE, and TCA) extending south into; (3) the southwestern corner of the CAS Building (PCE); (4) northeast of the TFTR Neutral Beam Power Conversion and Mockup Buildings (PCE, TCE, and TCA); and (5) west of the TFTR Field Coil Power Conversion Building (TCA) (see Fig.33-37).

It appeared that the source of tetrachloroethene (PCE) was localized within the "hot spot" areas and not a part of a large regional contamination plume.

\subsubsection{Groundwater Assessment}

As a result of the the soil gas survey (see 6.7.3), UST issues, and NJPDES permit requirements, a groundwater assessment was initiated in November 1990. The objective of 
the assessment was two-fold: (1) determine the impact of the underground storage tanks on groundwater and (2) correlate the soil-gas survey results with groundwater quality.

Sixteen wells and two piezometers were installed in December 1990 and sampled in January 1991. The initial results indicate that potential groundwater contamination is less severe than the soil gas survey indicated; however, it must be remembered that the soil gas survey is qualitative and not quantitative. The results of this study will be reported in the 1991 Annual Site Environmental Report.

\subsection{GROUNDWATER PROTECTION}

As part of our NJPDES permit, groundwater sampling was begun at the end of 1989 on seven additional wells (D-11, D-12, MW-14, MW-15, MW-16, TW2, and TW3). The data are indicated in Tables 34-40. The permit number is the same as the surface water, NJ0023922, with an effective date of May 1, 1989, and an expiration date of May 1, 1994. In addition, two former production wells, W4 and W5 (see Table 41), were monitored.

Other monitoring data included base neutrals and volatile organics (Tables 42-44), some miscellaneous data (Table 45), and general chemistry (Table 46). The solvents PCE, TCE, and TCA were all found in trace amounts in either wells D-11 or D-12 or in the inflow from D-site during the August 1990 sampling; but they were not indicated in the May 1990 sampling.

Groundwater assessment (see 6.7.4) initiated in 1990 will continue into 1991-92 to further characterize groundwater quality and the direction of flow.

\subsection{QUALITY ASSURANCE}

Analysis of water samples tor radioactivity was accomplished in-house. In general, inhouse procedures follow the HASL-300 Manual [Vo82]. In-house procedures adopt accepted techniques and are documented in the Radiological Environmental Monitoring Laboratory (REML) manual [REML90]. PPPL participates in the EPA (Las Vegas) program and the DOE Environmental Measurements Laboratory (EML) in New York City. These programs provide blind samples for analysis and subsequent comparison to values obtained by other participants, as well as to known values. Results are shown in Table 48. 
In CY84, PPPL initiated a program to have its radiation-counting laboratory certified by the State of New Jersey through the EPA Quality Assurance (QA) program. In March 1986, the REML facilities and procedures were reviewed and inspected by EPA/Las Vegas and the NJDEP. The laboratory was certified for tritium analysis in urine and water and recertified in these areas in 1988,1989, and 1990. While the certification was expected to have been extended to gamma spectroscopy in 1990, as all of the blind samples to date have been within expected detection limits (see Table 48 and Figs. 38 and 39), an official site visit has not been made by NJDEP to authorize this certification.

Two different vendors were used for nonradioactive water quality analysis in 1990 . They participate in a state of New Jersey QA program and have quality assurance plans [A185], [NAC90]. A blind split-sample was also sent for analysis (Table 49).

\subsection{ACKNOWLEDGEMENTS}

D. Hwang, M. Lewis, J. Greco, and J. Gilbert compiled the data for radiation analysis. O. Griesbach and $R$. Leuenberger performed in-house radiation analyses, and $R$. Frankenfield, K. Chase, and J. Lehner worked on instrument installation and calibration. These individuals are staff members of the PPPL ES\&H Division, Health Physics Branch. W. Slavin, the PPPL Industrial Hygienist, and V. Finley, the PPPL Environmental Engineer, reviewed nonradioactive pollutant analysis data. C. Kircher is responsible for all water-utilization information and V. Finley, the environmental engineer, is now responsible for the preparation of relevant data to DOE for environmental protection permits. J. Levine, the Nuclear/Environmental Engineer, provided NESHAPs calculations. S. Larson is responsible for hazardous-waste disposal. Various other PPPL individuals have reviewed the manuscript.

This work is supported by the U.S. Department of Energy Contract No. DE-AC02$76 \mathrm{CHO} 3073$. 


\subsection{REFERENCES}

A185 Alinea, E. A., 1985, Princeton Testing Laboratory Quality Control Manual, Princeton "esting Laboratory, Princeton, NJ.

Be87a Beniz, L. K., and Bender, D. S., 1987, "Population Projections, 0-50 Mile Radius from the CIT Facility: Supplementary Documentation for an Environmental Assessment for the CIT at PPPL," EGG-EP-7751, INEL, Idaho Falls, Idaiio.

Be87b Bentz, L. K., and Bender, D. S., 1987, "Socioeconomic Irformation, Plainsborc Area, New Jersey: Supplementary Documentation for an Environmental Assessment for the CIT at PPPL," EGG-EP-7752, INEL, Idaho Falls, Idaho.

CEE90 Corporate Environmental Engineering, June 1990, "Waste Minimization Study and Industrial Products Review," Corporate Environmental Engineering, Inc., Princeton, NJ, A Report to PPPL under Subcontract No. S-03225-G.

CFR90 Title 10, Code of Federal Regulations, Part 1022, "Compliance with Floodplain/Wetlands Environmental Review Requirements."

Ch91 Chase, K., 2/2/91, "Rainfall Data D-Site 1990," Princeton Plasma Physics Laboratory, Internal Memo.

Co81 Corley, J. P. et al., 1982, A Guide for: Environmental Radiological Surveillance at U.S. Department of Energy Ins'allations DOE/EP-023, (National Technical Information Service).

DOE88a Environmental Survey Sampling and Analysis Plan, November 1988, PPPL $S \& A$ Plan, INEL/EG\&G report to DOE.

DOE88b DOE Order 4330.2C, 3/23/88, In-House Energy Management.

DOE89 DOE Order 5480.11,7/20/89, Radiation Protection for Occupational Workers.

DOE90a DOE Order 5400.5, 6/5/90, Radiation Protection of the Public and the Environment.

DOE90b DOE Order 5400.1, 6/29/90, General Environmental Protection Program.

En87 Envirosphere Company, 1987, "Ecological Survey of Compact Ignition Tokamak Site and Surroundings at Princeton University's Forrestal Campus," Envirosphere Company, Division of Ebasco, Report to INEL for the CIT.

EPA89 US Environmental Protection Agency, Octo'er 1989, Users Guide for the Comply Code, EPA 520/1-89-003.

Fi91 Finley, V., January 1991, "Environmental Protection Spill Cleanup Report EP9101, Hydraulic Oil Incident, Novernber 1, 1990," VLF-004, NJDEP ID. No. 90-11-011524, PPPL Internal Report of the Environmental Protection Committee.

F184 Fleming, R. B. et al, February 1984, Safety Assessment Document for the Princeton Beta Experiment, Princetoil Plasma Physics Laboratory (unpublished). 
FSAR82 Final Safety Analysis Report. Tokamak Fusion Test Reactor Facilities, Princeton Plasmas Physics Laboratory, 1982.

Gi91 Gilbert, J., et. al, May 1991, "PPPL Ionizing Radiation Report for Calendar Year 1990," JG-160, Princeton Plasma Physics Laboratory Internal Report.

Gr85 Griesbach, O. A., and Stencel, J. R., "An Environmental Monitoring Program for a Fusion Test Reactor," Proceedings of the 18th Midyear Topical Meeting of the Health Physics Society, Colorado Springs, CO, Jan. 6-10, 1985, pp.227-233.

Gr88a Griesbach, O. A., and Stencel, J. R., "Operational Experience with the DATS Sampler During the Canadian Tritium Modeling Experiment, " Fusion Technology, 14, Part 2A, Sept. 1988, 1199-1202.

Gr88b Griesbach, O. A., and Stencel, J. R., "The PPPL Differential Atmospheric Tritium Sampler (DATS)," Proceedings of the 22nd Midyear Topical Meeting of the Health Physics Society, San Antonio, TX, Dec.4-8, 1988, pp. 374-380.

He88 Hendel, H., 1988, personal communication.

He89 Hendel, H, 1989, personal communication.

Ja90a Jassby, D., 1990, personal communication.

Ja90b Jassby, D., 1990, personal communication.

Jo74 Jordan, C. F., Stewart, M., and Kline, J., 1974, "Tritium Movement in Soils: The Importance of Exchange and High Initial Dispersion," Health Physics. 27, 37-43.

Ki88 Kircher, C., 3/14/88, "Calculations for Boiler Emissions, " Princeton Plasma Physics Laboratory, Internal Memo.

Ki91 Kircher, C., 3/8/91, "Annual Environmental Report for CY90," Princeton Plasma Physics Laboratory, Internal Memo.

Ko86a Kolibal, J., et al, 1986, Meteorological Data Summaries for the TFTR from January 1984 to December 1985, Princeton Plasma Physics Laboratory Report No. PPPL-2369.

Ko86b Kolibal, J., 3/24/86, "Sectorized Agricultural and Population Data Estimates," EAD-1442, Plasma Physics Laboratory Internal Memo.

Ku89 Ku, Long-poe, 4/18/89, "Wind Roses 1984-89," EAD-3389, Plasma Physics Laboratory Internal Memo.

Ku91 Kugel, H., 1991, personal communication.

La91 Larson, S. B., 3/21/91, " 1990 Hazardous Waste Report Detailing Princeton Plasma Physics Laboratory's Hazardous Waste Activity for Calendar Year 1990."

Le87 Lewis, J. C. and Spitz, F. J., 1987, "Hydrogeology, Ground-Water Quality, and The Possible Effects of a Hypothetical Radioactive-Water Spill, Plainsboro Township, New Jersey," U.S. Geological Survey Water-Resources Investigations Report 874092, West Trenton, NJ. 
Mc83 McCarthy, E. F., and Errera, L. J., 8/15/83, Final Monitoring Plan: Tokamak Fusion Test Reactor Meteorological Monitoring Program. TRC Consultants, Inc., 800 Connecticut Blvd., East Hartford, CT 06108.

Mc89 McKenzie-Carter, M. A. and Lyon, R. E., "Methodology for Assessing the Radiological Consequences of Radioactive Releases from the CIT Facility at PPPL," EGG-ESE-8600, Idaho National Engineering Laboratory (INEL) Informal Report (August 1989) $73 \mathrm{pp}$.

Mu77 Murphy, C. E., Jr., Watts, J. R., and Corey, J. C., 1977, "Environmental Tritium Transport from Atmospheric Release of Molecular Tritium," Health Physics, 33, 325-331.

Mu82 Murphy, C. E., Jr., Sweet, C. W., and Fallon, R. D., 1982, "Tritium Transport Around Nuclear Facilities," Nuclear Safety, 23, 667-685.

Mu90 Murphy, C. E., Jr., 1990, The Transport. Dispersion, and Cycling of Tritium in the Environment, Savannah River Site Report, WSRC-RP-90-462, UC702, 70 pp.

Os88 Ostlund, G., University of Miami, private communication, November 1988.

NAC90 Northeastern Analytical Corporation, July 90, Quality Assurance/Quality Control QA/OC Plan. Northeaster Analytical Corporation, Marlton, NJ, NAC/ENL: QA100.00.

Ne90 Nelson, D., September 1990, Final Report on the Findings of the Petrex Soil Gas Survey Conducted at Princeton Plasma Physics Laboratory on the Forrestal Campus in Plainsboro. New Jersey, Northeast Research Institute, Inc. Report, Farmington, Conn.

PSAR78 Preliminary Safety Analysis Report. Princeton Plasma Physics Laboratory Tokamak Fusion Test Reactor 1978.

Ra91 Rabiger, E., March 1991, “1990 Grounds Treatment," Princeton Plasma Physics Laboratory internal memo.

REML90, March 1990, Radiological Environmental Monitoring Laboratory Manual, Princeton Plasma Physics Laboratory Health Physics Document.

Sa89 Savy, J. B., "Princeton Plasma Physics Laboratory (PPPL) Seismic Hazard Analysis," UCID Report-21829 (October 1989) 138 pp.

St81 Steiner, P. A., 1981, An Aerial Radiological Survey of the Princeton Plasma Physics Laboratory and Surrounding Area, U.S. DOE Remote Sensing Laboratory

St82 Strenge, D. L., Kennedy, W. E., Jr, and Corley, J. P., 1982, Environmental Dose Assessment Methods for Normal Qperations of DOE Nuclear Sites. PNL4410/UC-11.

St88a Stencel, J. R. and Parsells, R. F., Editors, April 1988, Safety Assessment Document (SAD) for the Princeton Beta Experiment Modification (PBX-M), Princeton Plasma Physics Laboratory Report PPPL-2496. 
St88b Stencel, J. R., Gilbert, J. D., Griesbach, O. A., and Greco, J. M., "TFTR Health Physics Tritium Measurements Following D-D Operations," Fusion Technology, 14, Part 2A; 1047-1053; Sept. 1988.

St88c Stencel, J. R., May 1988, Environmental Monitoring Report for Calendar Year 1987, Princeton Plasma Physics Laboratory Report PPPL-2496.

St88d Stencel, J. R., 1988, "Environmental Protection Spill Cleanup Report EP88-01, NB Transformer, January 19, 1988," DEP ID \#88-01-19-1617, Internal PPPL Environmental Protection Committee Report.

St89 Start, G. E., Dickson, C. R., Sagendorf, J. F., Ackermann, G. R., Clawson, K. L., Johnson, R. C., and Hukari, N. F., "Atmospheric Diffusion for Airflows in the Vicinity of the James Forrestal Campus, Princeton University," Final Report, U.S. Department of Commerce, National Oceanic and Atmospheric Administration, Environmental Research Laboratories, Air Resources Laboratory Field Research Division, Idaho Falls, Idaho, Vol. 1 (May 1989) 84 pp, Vol. 2 (June 1989) 385 pp.

St9() Stencel, J. R., August 1990, "Environmental Protection Spill Cleanup Report EP90-2, Nitric Acid-Acetone Incident August 9, 1990," JRS-1841, NJDEP ID. No. 90-08-09-1320, PPPL Internal Report of the Environmental Protection Committee.

St91 Stencel, J. R., and Turrin, R. P., March 1991, Environmental Monitoring Report for Calendar Year 1989, Princeton Plasma Physics Laboratory Report PPPL-2739.

Sz87 Szabo, Z. and Zapecza, O. S., "Relation Between Natural Radionuclide Activities and Chemical Constituents in Ground Water in the Newark Basin, New Jersey," Radon, Radium, and Other Radioactivity in Ground Water, Hydrogeologic Impact and Application to Indoor Airborne Contamination, Proceedings of the National Water Well Association Conference April 7-9, 1987, Somerset, NJ, available from Lewis Publishers.

Tu90) Turrin, R. P., April 1990, "Environmental Protection Spill Cleanup Report EP901, Chromium Sands Spill in the Plant Maintenance and Engineering Yard," RPT-66, NJDEP ID. No. 90-03-23-1551, PPPL Internal Report of the Environmental Protection Committee.

Vo82 Volchok, H. L., and de Planque, G., 1982, EML Procedures Manual HASL 300 , Department of Energy, Environmental Measurements Laboratory, 376 Hudson St., NY, NY 10014.

Za87 Zapecza, O. S. and Szabo, Z., "Source and Distribution of Natural Radioactivity in Ground Water in the Newark Basin, New Jersey," Radon, Radium, and Other Radioactivity in Ground Water, Hydrogeologic Impact and Application to Indoor Airborne Contamination, Proceedings of the National Water Well Association Conference, April 7-9, 1987, Somerset, NJ, available from Lewis Publishers. 
Table 1. TFTR/BPX Radiological Design Objectives and Regulatory Limits(a)

\begin{tabular}{|c|c|c|c|c|c|}
\hline \multirow[t]{2}{*}{ CONDITION } & & \multicolumn{2}{|r|}{ EXPOSURE $^{(b)}$} & \multicolumn{2}{|c|}{ OCCUPATIONAL EXPOSURE } \\
\hline & & $\begin{array}{l}\text { REGULATOFY } \\
\text { LIMIT }\end{array}$ & $\begin{array}{l}\text { DESIGN } \\
\text { OBUECTIVE }\end{array}$ & $\begin{array}{l}\text { REGULATORY } \\
\text { LIMIT }\end{array}$ & $\begin{array}{l}\text { DESIGN } \\
\text { OBJECTIVE }\end{array}$ \\
\hline \multirow{2}{*}{$\begin{array}{l}\text { ROUTINE } \\
\text { OPERATION } \\
\text { Dose equivalent } \\
\text { to an individual } \\
\text { from routine } \\
\text { operations } \\
\text { (rem per year, } \\
\text { unless otherwise } \\
\text { indicated) }\end{array}$} & $\begin{array}{l}\text { NORMAL } \\
\text { OPERATIONS }\end{array}$ & $\begin{array}{l}0.1 \\
\text { Total, } \\
0.01(c) \\
\text { Airborne, } \\
0.004 \\
\text { Drinking } \\
\text { Water }\end{array}$ & $\begin{array}{l}0.01 \\
\text { Total }\end{array}$ & \multirow[t]{2}{*}{5} & \multirow[t]{2}{*}{1} \\
\hline & $\begin{array}{l}\text { ANTICIPATED } \\
\text { EVENTS } \\
\left(1>P \geq 10^{-2}\right)\end{array}$ & $\begin{array}{l}0.5 \\
\text { Total } \\
\text { (including } \\
\text { normal } \\
\text { operation) }\end{array}$ & $\begin{array}{l}0.05 \text { per } \\
\text { event }\end{array}$ & & \\
\hline \multirow{3}{*}{$\begin{array}{l}\text { ACCIDENTS } \\
\text { Dose equivalent } \\
\text { to an individual } \\
\text { from an } \\
\text { accidental } \\
\text { release (rem } \\
\text { per event) }\end{array}$} & $\begin{array}{l}\text { UNLIKELY } \\
\text { EVENTS } \\
10^{-2}>P \geq 10^{-4}\end{array}$ & 2.5 & 0.5 & (ө) & (e) \\
\hline & $\begin{array}{l}\text { EXTREMELY } \\
\text { UNLIKELY } \\
\text { EVENTS } \\
10^{-4}>P \geq 10^{-6}\end{array}$ & 25 & $5_{5}(d)$ & (e) & (e) \\
\hline & $\begin{array}{l}\text { INCREDIBLE } \\
\text { EVENTS } \\
10^{-6}>\mathrm{P}\end{array}$ & NA & NA & NA & NA \\
\hline
\end{tabular}

$P=$ Probability of occurrence in a year.

(a) All operations must be planned to incorporate the radiation safety guidelines, practices and procedures included in PPPL ESHD 5008, Section 10.

(b) Evaluated at the PPPL site boundary.

(c) Compliance with this limit is to be determined by calculating the highest effective dose equivalent to

any member of the public at any offsite point where there is a residence, school, business or office.

(d) For design basis accidents (DBAs), i.e., postulated accidents or natural forces and resulting conditions for which the confinement structure, systems, components and equipment must meet their functional goals, the design objective is $0.5 \mathrm{rem}$.

(c) Sce PPPL ESHD-5008, Section 10, Chapter 12 for emergency personnel exposure limits. 
Path I.D.

Al

A2

A3

L1

L2

L3

\section{Discharge Pathway}

Whole Body Exposure

Inhalation Exposure

Deposition on Soil \& Vegetation, Ingestion, Whole Body Exposure

Liquid

Water Way --->

Drinking Water Supply --> Man

Liquid

Water Way -.-->

External Exposure

Liquid Water Way -.->

Fish ...> Man 
Table 3. Monitoring Program Covering Critical Pathways

\begin{tabular}{|c|c|c|c|c|}
\hline $\begin{array}{l}\text { Type of } \\
\text { Sample }\end{array}$ & $\begin{array}{c}\text { Critical Path } \\
\text { I.D. } \\
\end{array}$ & $\begin{array}{c}\text { Sample Point } \\
\text { Description }\end{array}$ & $\begin{array}{l}\text { Sampling } \\
\text { Frequency }\end{array}$ & Analysis \\
\hline Surface & $\begin{array}{c}\mathrm{L} 1, \mathrm{~L} 2, \mathrm{~L} 3 \\
\& \\
\mathrm{~A} 3\end{array}$ & $\begin{array}{l}\text { 1) Cooling } \\
\text { Water } \\
\text { Discharge } \\
\text { Drainage } \\
\text { 2) Bee Brook } \\
\text { Upstream \& } \\
\text { Downstream } \\
\text { 3) D\&R Canal }\end{array}$ & Monthly & $\begin{array}{l}\text { Tritium and Gamma } \\
\text { Spectroscopy }\end{array}$ \\
\hline Soil \& Sod & A3 & $\begin{array}{l}\text { Within } 1 \mathrm{~km} \\
\text { radius }\end{array}$ & & $\begin{array}{l}\text { Tritium and Gamma } \\
\text { Spectroscopy }\end{array}$ \\
\hline $\begin{array}{l}\text { Biota (Fruits \& } \\
\text { Vegetables) }\end{array}$ & A3 & $\begin{array}{l}\text { Within } 3 \mathrm{~km} \\
\text { radius }\end{array}$ & Seasonal & $\begin{array}{l}\text { Tritium \& Gamma } \\
\text { Spectroscopy }\end{array}$ \\
\hline Surface Water & $\mathrm{L} 1, \mathrm{~L} 2$ & $\begin{array}{l}\text { Liquid Effluent } \\
\text { Collection Tanks }\end{array}$ & $\begin{array}{c}\text { As Required by } \\
\text { Filling }\end{array}$ & $\begin{array}{c}\text { Tritium and Gamma } \\
\text { Spectroscopy, } \\
\text { Volume }\end{array}$ \\
\hline Air & $\mathrm{A} 1-\mathrm{A} 3$ & Test Cell & Continuous & $\begin{array}{c}\text { Activated Air } \\
\text { (Gross } \beta)^{3} \mathrm{H}(\mathrm{HT} \\
\text { and HTO) }\end{array}$ \\
\hline Air & $A 1-A 3$ & Vault & Continuous & ${ }^{3} \mathrm{H}(\mathrm{HT}$ and $\mathrm{HTO})$ \\
\hline Air & $\mathrm{A} 1-\mathrm{A} 3$ & $\begin{array}{l}\text { HVAC } \\
\text { Discharge } \\
\text { (Stack) }\end{array}$ & Continuous & $\begin{array}{c}\text { Activated Air } \\
\text { (Gross } \beta \text { ) HT and } \\
\text { HTO, Particulates, } \\
\text { Volume }\end{array}$ \\
\hline $\begin{array}{c}\text { Direct \& Air } \\
\text { (on-site) }\end{array}$ & & $\begin{array}{l}4 \text { Locations at } \\
\text { TFTR Facility } \\
\text { Boundary }\end{array}$ & Continuous & $\begin{array}{c}\gamma, \mathrm{n},{ }^{3} \mathrm{H}(\mathrm{HT} \text { and } \\
\text { HTO), Gross } \beta \text { for } \\
\text { activated air \& } \\
\text { particulates with } \\
\text { Gamma } \\
\text { Spectroscopy, TLD }\end{array}$ \\
\hline $\begin{array}{l}\text { Direct \& Air } \\
\text { (off-site) }\end{array}$ & & $\begin{array}{l}6 \text { Locations off- } \\
\text { site within } 1 \mathrm{~km} \\
\text { radius }\end{array}$ & $\begin{array}{l}\text { Continuous } \\
\text { (integrated) }\end{array}$ & $\begin{array}{c}{ }^{3} \mathrm{H} \text { (HT and HTO), } \\
\text { TLD for air } \gamma \\
\text { Gamma Spec. for } \\
\text { particulates }\end{array}$ \\
\hline
\end{tabular}




\section{Table $4^{*}$}

Population of Municipalities Within 0-10 Miles of PPPL 1985-2010

\begin{tabular}{|c|c|c|c|c|c|c|}
\hline Municipality & $1985^{1}$ & 1995 & 2000 & 2005 & 2010 & \\
\hline $\begin{array}{l}\text { Mercer County (Tutal) } \\
\text { Mercer County (Part) }\end{array}$ & $\begin{array}{l}317,685 \\
190,683\end{array}$ & $\begin{array}{l}349,700 \\
219,550\end{array}$ & $\begin{array}{l}359,400 \\
228,100\end{array}$ & $\begin{array}{l}364,200 \\
230,550\end{array}$ & $\begin{array}{l}377,100 \\
240,500\end{array}$ & $\begin{array}{l}\text { Mercer County (Total) } \\
\text { Mercer County (Part) }\end{array}$ \\
\hline $\begin{array}{l}\text { East Windsor Twp. } \\
\text { Hightstown Borough } \\
\text { Hamilton Twp. } \\
\text { Hopewell Twp. } \\
\text { Hopewell Borough } \\
\text { Pennington Borough } \\
\text { Lawrence Twp. } \\
\text { Princeton Twp. } \\
\text { Princeton Borough } \\
\text { W'ashington Twp. } \\
\text { West Windsor Twp. }\end{array}$ & $\begin{array}{r}22,682 \\
4,494 \\
85,766 \\
11,040 \\
2,013 \\
2,232 \\
22,804 \\
14,202 \\
12,031 \\
3,719 \\
9,700\end{array}$ & $\begin{array}{r}24,750 \\
5,050 \\
88,850 \\
13,025 \\
2,075 \\
2,300 \\
31,100 \\
14,550 \\
12,650 \\
8,650 \\
16,550\end{array}$ & $\begin{array}{r}26,000 \\
5,100 \\
90,000 \\
15,000 \\
2,100 \\
2,300 \\
33,900 \\
14,700 \\
12,700 \\
8,800 \\
17,550\end{array}$ & $\begin{array}{r}26,350 \\
5,100 \\
91,200 \\
15,200 \\
2,100 \\
2,350 \\
34,000 \\
14,900 \\
12,700 \\
8,900 \\
17,750\end{array}$ & $\begin{array}{r}29,350 \\
5,100 \\
94,450 \\
16,200 \\
2,100 \\
2,400 \\
34,100 \\
15,400 \\
12,700 \\
9,200 \\
19,500\end{array}$ & $\begin{array}{l}\text { East Windsor Twp. } \\
\text { Hightstown Borough } \\
\text { Hamilton Twp. } \\
\text { Hopewell Twp. } \\
\text { Hopewell Borough } \\
\text { Pennington Borough } \\
\text { Lawrence Twp. } \\
\text { Princeton Twp. } \\
\text { Princeton Borough } \\
\text { Washington Twp. } \\
\text { West Windsor Twp. }\end{array}$ \\
\hline $\begin{array}{l}\text { Middlesex County (Tota } \\
\text { Middlesex County (Par) }\end{array}$ & $\begin{array}{l}1)^{2} 626,703 \\
121,984\end{array}$ & $\begin{array}{l}695,432 \\
171,183\end{array}$ & $\begin{array}{l}724,610 \\
192,396\end{array}$ & $\begin{array}{l}760,800 \\
202,000\end{array}$ & $\begin{array}{l}791,800 \\
219,100\end{array}$ & $\begin{array}{l}\text { Middlesex County (Total) } \\
\text { Middlesex County (Part) }\end{array}$ \\
\hline $\begin{array}{l}\text { Cranbury Twp. } \\
\text { East Brunswick Twp. } \\
\text { Hclmctla Borough } \\
\text { Monroc Twp. } \\
\text { Jamesburg Borough } \\
\text { North Brunswick Twp. } \\
\text { Plainsboro Twp. } \\
\text { South Brunswick Twp. }\end{array}$ & $\begin{array}{r}2,145 \\
40,770 \\
973 \\
19,255 \\
4,402 \\
25,427 \\
9,040 \\
19,972\end{array}$ & $\begin{array}{r}5,695 \\
43,630 \\
965 \\
28,711 \\
4,723 \\
31,495 \\
15,662 \\
40,304\end{array}$ & $\begin{array}{r}8,033 \\
44,753 \\
949 \\
34,737 \\
4,805 \\
33,916 \\
17,161 \\
48,042\end{array}$ & $\begin{array}{r}8,450 \\
47,000 \\
950 \\
36,500 \\
5,050 \\
35,600 \\
18,000 \\
50,450\end{array}$ & $\begin{array}{r}8,800 \\
50,900 \\
950 \\
38,200 \\
5,050 \\
37,000 \\
20,700 \\
57,500\end{array}$ & $\begin{array}{l}\text { Cranbury Twp. } \\
\text { East Brunswick Twp. } \\
\text { Helmetta Borough } \\
\text { Monroe Twp. } \\
\text { Jamesburg Borough } \\
\text { North Brunswick Twp. } \\
\text { Plainsboro Twp. } \\
\text { South Brunswick Twp. }\end{array}$ \\
\hline $\begin{array}{l}\text { Somerset County (Total) } \\
\text { Somerset County (Part) }\end{array}$ & $\begin{array}{c}2210,318 \\
65,276\end{array}$ & $\begin{array}{r}250,025 \\
89,280\end{array}$ & $\begin{array}{r}263,800 \\
97,820\end{array}$ & $\begin{array}{l}279,765 \\
106,610\end{array}$ & $\begin{array}{l}295,730 \\
115,400\end{array}$ & $\begin{array}{l}\text { Somerset County (Total) } \\
\text { Somerset County (Part) }\end{array}$ \\
\hline $\begin{array}{l}\text { Franklin Twp. } \\
\text { Hillsborough Twp } \\
\text { Montgomery Twp. } \\
\text { Rocky Hill Borough }\end{array}$ & $\begin{array}{r}33,952 \\
22,652 \\
7,970 \\
702\end{array}$ & $\begin{array}{r}47,945 \\
28,485 \\
12,145 \\
705\end{array}$ & $\begin{array}{r}52,790 \\
30,900 \\
13,420 \\
710\end{array}$ & $\begin{array}{r}57,790 \\
33,375 \\
14,725 \\
720\end{array}$ & $\begin{array}{r}62,790 \\
35,850 \\
16,030 \\
730\end{array}$ & $\begin{array}{l}\text { Franklin Twp. } \\
\text { Hillsborough Twp. } \\
\text { Montgomery Twp. } \\
\text { Rocky Hill Borough }\end{array}$ \\
\hline $\begin{array}{l}\text { Monmouth County (Tot } \\
\text { Millstone Twp. }\end{array}$ & $\begin{array}{c}\mathrm{al})^{2} 530,913 \\
4,234\end{array}$ & $\begin{array}{r}568,100 \\
5,617\end{array}$ & $\begin{array}{r}591,600 \\
7,000\end{array}$ & $\begin{array}{r}604,300 \\
9,286\end{array}$ & $\begin{array}{r}613,450 \\
11.571\end{array}$ & $\begin{array}{l}\text { Monmouth County } \\
\text { Millstone Twp. }\end{array}$ \\
\hline
\end{tabular}


Table $5^{*}$

Population of Counties Within 0-50 Miles of PPPL $1985-2010$

\begin{tabular}{|c|c|c|c|c|c|c|}
\hline County & $\begin{array}{c}1985 \\
\text { Estimates }\end{array}$ & $\begin{array}{c}1995 \\
\text { Projections }\end{array}$ & $\begin{array}{c}2000 \\
\text { Projections }\end{array}$ & $\begin{array}{l}2005 \\
\text { Projections }\end{array}$ & $\begin{array}{l}2010 \\
\text { Projections }\end{array}$ & \\
\hline New Jerseyl & $7,562,000$ & $8,154,000$ & $8,450,300$ & $8,685,200$ & $8,895,700$ & New Jersey \\
\hline Atlantic & 205,100 & 245,100 & 260,100 & 272,300 & 283,200 & Allantic \\
\hline Bergen & 841,200 & 861,800 & 878,700 & 891,900 & 904,000 & Bergen \\
\hline Burlington & 380,100 & 437,100 & 467,200 & 494,900 & 521,300 & Burlington \\
\hline Camden & 488,100 & 555,400 & 577,200 & 597,300 & 616,700 & Camden \\
\hline Essex & 845,700 & 794,000 & 795,500 & 779,900 & 762,300 & Essex \\
\hline Gloucester & 207,100 & 234,500 & 249,100 & 263,500 & 277,400 & Gloucester \\
\hline Hudson & 555,900 & 560,100 & 548,100 & 528,500 & 507,300 & Hucison \\
\hline Huntcrdon & 92,800 & 104,500 & 113,000 & 121,900 & 131,000 & Hunterdon \\
\hline Merecr & 317,700 & 349,700 & 359,400 & 364,200 & 377,100 & Mercer \\
\hline Midddlesex & 626,700 & 695,432 & 724,610 & 760,800 & 791,800 & Middlesex \\
\hline Monmouth & 530,900 & 568,100 & 591,600 & 604,300 & 613,450 & Monmouth \\
\hline Morris & 417,100 & 479,900 & 510,500 & 540,800 & 570,500 & Morris \\
\hline Occan & 380,000 & 449,600 & 484,400 & 515,800 & 545,900 & Ocean \\
\hline Passaic & 461,400 & 468,600 & 469,100 & 466,500 & 462,000 & Passaic \\
\hline Somerset & 210,318 & 250,025 & 263,800 & 279,765 & 295,730 & Somerset \\
\hline Sussex & 119,600 & 146,100 & 159,600 & 172,900 & 185,700 & Sussex \\
\hline Union & 506,700 & 534,500 & 539,700 & 540,900 & 540,000 & Union \\
\hline Warren & 85,200 & 700 & 96,200 & 99,300 & 101,900 & Warren \\
\hline Ncw York ${ }^{2}$ & $17,783,000$ & $18,314,022$ & $18,548,262$ & $18,750,076$ & $18,948,273$ & New York \\
\hline Bronx & $1,198,598$ & $1,199,410$ & $1,205,047$ & $1,213,270$ & $1,224,052$ & Bronx \\
\hline Kings & $2,248,139$ & $2,228,361$ & $2,232,835$ & $2,242,890$ & $2,254,228$ & Kings \\
\hline Nassau & $1,332,393$ & $1,344,197$ & $1,333,458$ & $1,315,938$ & $1,292,457$ & Nassau \\
\hline New York & $1,455,619$ & $1,454,633$ & $1,454,251$ & $1,456,292$ & $1,456,707$ & New York \\
\hline Qucens & $1,917,172$ & $1,919,057$ & $1,925,510$ & $1,933,829$ & $1,953,634$ & Queens \\
\hline Richmond & 371,679 & 419,706 & 443,048 & 465,818 & 489,111 & Richmond \\
\hline Pennsylvania ${ }^{3}$ & $11,863,674$ & $12,100,149$ & $12,101,253$ & $12,161,780$ & $12,222,306$ & Pennsylvania \\
\hline Bucks & 512,705 & 576,716 & 601,168 & 636,276 & 673,345 & Bucks \\
\hline Chester & 334,311 & 379,733 & 395,958 & 418,726 & 442,802 & Chester \\
\hline Delaware & 557,180 & 541,442 & 531,068 & 525,279 & 519,554 & Delaware \\
\hline Lehigh & 277,914 & 291,083 & 294,836 & 300,762 & 306,808 & Lehigh \\
\hline Monroe & 78,967 & 104,133 & 117,583 & 134,162 & 153,079 & Monroe \\
\hline Montgomery & 663,164 & 692,521 & 698,281 & 712,666 & 727,346 & Montgomery \\
\hline Northhampton & 231,430 & 244,668 & 249.000 & 255,275 & 261,707 & Northhamptor \\
\hline Philadelphia & $1,637,434$ & $1,599,620$ & $1,513,674$ & $1,472,959$ & $1,433,333$ & Philadephia \\
\hline
\end{tabular}

\footnotetext{
* Taken from Bender [Be87a].

1 Officc of Demographic and Economic Analysis, N.J. Department of Labor and Industry, 1986.

2 Stute Data Center, New York State Department of Commerce, 1985.

3 State Data Center, Pennsylvania Department of Commerce, 1986. See methodology in Be87 Appendix for dctails on 2005 and 2010 projections.
} 
Table $6^{*}$

Population of Metropolitan Areas Within 50 Miles of PPPL

\begin{tabular}{|c|c|c|c|}
\hline Metropolitan Areas ${ }^{1}$ & $\begin{array}{l}1980 \\
\text { Census }\end{array}$ & $\begin{array}{l}\text { July } 1985 \\
\text { Estimate }\end{array}$ & $\begin{array}{l}\text { Percent } \\
\text { Change }\end{array}$ \\
\hline $\begin{array}{l}\text { Allentown-Bethlehem MSA } \\
\text { (NJ Portion) }\end{array}$ & 84,429 & 85,200 & $0.9 \%$ \\
\hline Jersey City, NJ PMSA & 556,972 & 555,900 & $-0.2 \%$ \\
\hline Monmouth-Ocean PMSA & 849,211 & 910,900 & $7.3 \%$ \\
\hline Middlesex-Somerset-Hunterdon PMSA & 886,383 & 929,800 & $4.9 \%$ \\
\hline New York, NY CMSA & $8,274,961$ & $8,410,058$ & $1.6 \%$ \\
\hline Newark, NJ PMSA & $1,879,147$ & $1,889,000$ & $0.5 \%$ \\
\hline Bergen-Passaic PMSA & $1,292,970$ & $1,302,600$ & $0.7 \%$ \\
\hline $\begin{array}{l}\text { Philadelphia, PA PMSA } \\
\text { (NJ Portion) }\end{array}$ & $1,034,109$ & $1,075,300$ & $4.0 \%$ \\
\hline Trenton, NJ PMSA & 307,863 & 317,700 & $3.2 \%$ \\
\hline
\end{tabular}

\footnotetext{
* Taken from Bender [Be87a].

1 MSA = Metropolitan Statistical Area

CMSA = Consolidated Metropolitan Statistical Area

PMSA = Primary Metropolitan Statistical Area
}

Source: State of New Jersey, Department of Labor; New York State Deparment of Commerce 
Table $7^{*}$

1985 Population Estimates Within Annular Sectors, 0-10 Miles

Total

\begin{tabular}{crrrrrrrr}
\hline & $0-1$ & $1-2$ & $2-3$ & $3-4$ & $4-5$ & $5-10$ & $0-10$ & \\
Sector & Miles & Miles & Miles & Miles & Miles & Miles & Miles & Sector \\
& & & & & & & & \\
N & 0 & 100 & 289 & 0 & 68 & 4,666 & 5,123 & N \\
NNE & 0 & 20 & 290 & 2,497 & 4,334 & 9,600 & 16,741 & NNE \\
NE & 0 & 0 & 0 & 0 & 0 & 16,799 & 16,799 & NE \\
ENE & 0 & 1,160 & 204 & 200 & 100 & 3,792 & 5,456 & ENE \\
E & 0 & 0 & 200 & 100 & 10 & 10,238 & 10,548 & E \\
ESE & 0 & 100 & 1,600 & 1,200 & 219 & 3,469 & 6,588 & ESE \\
SE & 113 & 1,200 & 0 & 253 & 161 & 18,964 & 20,691 & SE \\
SSE & 362 & 50 & 150 & 0 & 600 & 8,255 & 9,417 & SSE \\
S & 0 & 734 & 3,837 & 2,312 & 1,760 & 4,156 & 12,799 & S \\
SSW & 3 & 0 & 2,500 & 600 & 100 & 27,788 & 30,991 & SSW \\
SW & 0 & 805 & 10 & 250 & 50 & 18,525 & 19,640 & SW \\
WSW & 0 & 739 & 1,000 & 1,019 & 1,449 & 8,095 & 12,302 & WSW \\
W & 0 & 1,735 & 5,820 & 6,777 & 2,386 & 6,253 & 22,971 & W \\
WNW & 40 & 437 & 772 & 3,139 & 0 & 2,013 & 6,401 & WNW \\
NW & 0 & 1,020 & 866 & 300 & 350 & 3,526 & 6,062 & NW \\
NNW & 0 & 600 & 499 & 200 & 502 & 7,093 & 8,894 & NNW \\
Totals & 518 & 8,700 & 18,037 & 18,847 & 12,089 & 153,232 & 211,423 & Totals
\end{tabular}

\footnotetext{
* Taken from Bender [Be87a]
} 


\section{Table $8^{*}$}

1995 Population Estimates Within Annular Sectors, 0-10 Miles

\begin{tabular}{crrrrrrrrr}
\hline & $0-1$ & $1-2$ & $2-3$ & $3-4$ & $4-5$ & $5-10$ & $0-10$ & \\
Sector & Miles & Miles & Miles & Miles & Miles & $\underline{\text { Miles }}$ & Miles & Sector \\
& & & & & & & & \\
N & 0 & 134 & 387 & 0 & 91 & 6,241 & 6,853 & N \\
NNE & 0 & 27 & 388 & 3,340 & 5,242 & 12,841 & 21,838 & NNE \\
NE & 0 & 0 & 0 & 486 & 902 & 21,084 & 22,472 & NE \\
ENE & 0 & 1,551 & 273 & 268 & 689 & 5,072 & 7,853 & ENE \\
E & 0 & 0 & 268 & 134 & 1,678 & 13,695 & 15,775 & E \\
ESE & 0 & 827 & 2,140 & 1,605 & 2,235 & 5,195 & 12,002 & ESE \\
SE & 151 & 1,605 & 291 & 338 & 493 & 20,928 & 23,806 & SE \\
SSE & 484 & 1,454 & 894 & 166 & 803 & 11,042 & 14,843 & SSE \\
S & 0 & 982 & 4,675 & 3,093 & 2,354 & 5,559 & 16,663 & S \\
SSW & 4 & 188 & 3,344 & 2,522 & 2,908 & 32,176 & 41,142 & SSW \\
SW & 0 & 1,077 & 332 & 544 & 2,796 & 21,450 & 26,199 & SW \\
WSW & 0 & 989 & 2,828 & 1,130 & 1,594 & 10,828 & 17,369 & WSW \\
W & 0 & 2,321 & 6,005 & 6,963 & 2,487 & 9,277 & 27,053 & W \\
WNW & 53 & 585 & 800 & 3,256 & 128 & 4,438 & 9,260 & WNW \\
NW & 0 & 1,365 & 898 & 335 & 468 & 4,716 & 7,782 & NW \\
NNW & 0 & 803 & 668 & 268 & 671 & 9,487 & 11,897 & NNW \\
Totals & 692 & 13,908 & 24,191 & 24,448 & 25,539 & 194,029 & 282,807 & Totals
\end{tabular}

\footnotetext{
* Tuken from Bender [Be87a]
} 
Table $9^{*}$

2000 Population Estimates Within Annular Sectors, 0-10 Miles

\begin{tabular}{crrrrrrrr}
\hline & $0-1$ & $1-2$ & $2-3$ & $3-4$ & $4-5$ & $5-10$ & $0-10$ & \\
Sector & Miles & Miles & Miles & Miles & Miles & Miles & Miles & Sector \\
& & & & & & & & \\
N & 0 & 146 & 421 & 0 & 99 & 6,792 & 7,458 & N \\
NNE & 0 & 29 & 422 & 3,635 & 5,560 & 13,974 & 23,620 & NNE \\
NE & 0 & 0 & 0 & 656 & 1,217 & 22,582 & 24,455 & NE \\
ENE & 0 & 1,688 & 297 & 292 & 895 & 5,520 & 8,692 & ENE \\
E & 0 & 0 & 292 & 146 & 2,261 & 14,904 & 17,603 & E \\
ESE & 0 & 1,081 & 2,329 & 1,747 & 2,940 & 5,799 & 13,896 & ESE \\
SE & 164 & 1,747 & 393 & 368 & 609 & 21,615 & 24,896 & SE \\
SSE & 527 & 1,945 & 1,154 & 224 & 874 & 12,016 & 16,740 & SSE \\
S & 0 & 1,069 & 4,968 & 3,366 & 2,562 & 6,050 & 18,015 & S \\
SSW & 4 & 254 & 3,639 & 3,869 & 3,890 & 33,710 & 45,366 & SSW \\
SW & 0 & 1,172 & 252 & 469 & 4,566 & 22,473 & 28,932 & SW \\
WSW & 0 & 1,076 & 2,354 & 1,169 & 1,645 & 11,784 & 18,028 & WSW \\
W & 0 & 2,526 & 6,070 & 7,028 & 2,522 & 10,334 & 28,480 & W \\
WNW & 58 & 637 & 810 & 3,297 & 173 & 5,286 & 10,261 & WNW \\
NW & 0 & 1,485 & 909 & 347 & 509 & 5,132 & 8,382 & NW \\
NNW & 0 & 874 & 727 & 292 & 730 & 10,316 & 12,939 & NNW \\
Totals & 753 & 15,729 & 25,037 & 26,905 & 31,052 & 208,287 & 307,763 & Totals
\end{tabular}

* Taken from Bender [Be87a] 


\section{Table $10^{*}$}

2005 Population Estimates Within Annular Sectors, 0-10 Miles

\begin{tabular}{crrrrrrrr}
\hline & $0-1$ & $1-2$ & $2-3$ & $3-4$ & $4-5$ & $5-10$ & $0-10$ & \\
Sector & Miles & Miles & Miles & Miles & Miles & Miles & Miles & Sector \\
& & & & & & & & \\
N & 0 & 151 & 435 & 0 & 102 & 7,014 & 7,702 & N \\
NNE & 0 & 30 & 436 & 3,754 & 5,688 & 14,431 & 24,339 & NNE \\
NE & 0 & 0 & 0 & 725 & 1,344 & 23,187 & 25,256 & NE \\
ENE & 0 & 1,743 & 307 & 302 & 978 & 5,701 & 9,031 & ENE \\
E & 0 & 0 & 302 & 151 & 2,496 & 15,392 & 18,341 & E \\
ESE & 0 & 1,184 & 2,405 & 1,804 & 3,224 & 6,043 & 14,660 & ESE \\
SE & 169 & 1,804 & 434 & 380 & 656 & 21,892 & 25,335 & SE \\
SSE & 544 & 2,143 & 1,259 & 247 & 903 & 12,409 & 17,505 & SSE \\
S & 0 & 1,104 & 5,086 & 3,476 & 2,646 & 6,248 & 18,560 & S \\
SSW & 4 & 281 & 3,758 & 4,211 & 4,286 & 34,329 & 46,869 & SSW \\
SW & 0 & 1,210 & 277 & 492 & 5,038 & 22,986 & 30,003 & SW \\
WSW & 0 & 1,111 & 2,496 & 1,185 & 1,666 & 12,170 & 18,628 & WSW \\
W & 0 & 2,609 & 6,096 & 7,054 & 2,536 & 10,761 & 29,056 & W \\
WNW & 60 & 658 & 814 & 3,313 & 191 & 5,628 & 10,664 & WNW \\
NW & 0 & 1,534 & 913 & 352 & 526 & 5,300 & 8,625 & NW \\
NNW & 0 & 903 & 751 & 302 & 754 & 10,651 & 13,361 & NNW \\
Totals & 777 & 16,465 & 25,769 & 27,748 & 33,034 & 214,142 & 317,935 & Totals
\end{tabular}

\footnotetext{
- Taken from Bender [Be87a]
} 


\section{Table $11^{*}$}

2010 Population Estimates Within Annular Sectors, 0-10 Miles

\begin{tabular}{|c|c|c|c|c|c|c|c|c|}
\hline & $0-1$ & $1-2$ & $2-3$ & $3-4$ & $4-5$ & $5-10$ & $0-10$ & \\
\hline$\underline{\text { Sector }}$ & Miles & Miles & $\underline{\text { Miles }}$ & Miles & $\underline{\text { Miles }}$ & $\underline{\text { Miles }}$ & $\underline{\text { Miles }}$ & Sector \\
\hline $\mathrm{N}$ & 0 & 161 & 465 & 0 & 109 & 7,505 & 8,240 & $\mathrm{~N}$ \\
\hline NNE & 0 & 32 & 466 & 4,016 & 5,971 & 15,441 & 25,926 & NNE \\
\hline $\mathrm{NE}$ & 0 & 0 & 0 & 875 & 1,625 & 24,521 & 27,021 & $\mathrm{NE}$ \\
\hline ENE & 0 & 1,865 & $j 28$ & 322 & 1,161 & 6,099 & 9,775 & ENE \\
\hline$E$ & 0 & 0 & 322 & 161 & 3,016 & 16,468 & 19,967 & $\mathrm{E}$ \\
\hline ESE & 0 & 1,411 & 2,574 & 1,930 & 3,852 & 6,580 & 16,347 & ESE \\
\hline$S E$ & 182 & 1,930 & 525 & 407 & 749 & 22,503 & 26,306 & SE \\
\hline SSE & 582 & 2,580 & 1,491 & 300 & 965 & 13,278 & 19,196 & SSE \\
\hline$S$ & 0 & 1,181 & 5,347 & 3,719 & 2,831 & 6,685 & 19,763 & $S$ \\
\hline SSW & 5 & 339 & 4,021 & 4,965 & 5,161 & 35,696 & 50,187 & SSW \\
\hline SW & 0 & 1,295 & 333 & 542 & 6,080 & 23,797 & 32,047 & sw \\
\hline WSW & 0 & 1,189 & 2,808 & 1,219 & 1,711 & 13,021 & 19,948 & WSW \\
\hline W & 0 & 2,791 & 6,154 & 7,112 & 2,568 & 11,703 & 30,328 & w \\
\hline WNW & 64 & 703 & 822 & 3,349 & 230 & 6,383 & 11,551 & WNW \\
\hline$N W$ & 0 & 1,641 & 923 & 363 & 563 & 5,671 & 9,161 & NW \\
\hline NNW & 0 & 965 & 803 & 322 & 807 & 11,408 & 14,305 & NNW \\
\hline Totals & 833 & 18,083 & 27,382 & 29,602 & $37,: 09$ & 226,759 & 340,068 & Totals \\
\hline
\end{tabular}




\section{Table $12^{*}$}

1985 Population Estimates Within Annular Sectors, 10-50 Miles

\section{Total}

\begin{tabular}{|c|c|c|c|c|c|c|}
\hline & $10-20$ & $20-30$ & $30-40$ & $40-50$ & $10-50$ & \\
\hline$\underline{\text { Sector }}$ & $\underline{\text { Miles }}$ & Miles & $\underline{\text { Miles }}$ & $\underline{\text { Miles }}$ & Miles & Sector \\
\hline $\mathrm{N}$ & 66,118 & 36,704 & 181,881 & 68,882 & 353,586 & $\mathrm{~N}$ \\
\hline NNE & 134,838 & 226,290 & 341,211 & 488,415 & $1,190,754$ & NNE \\
\hline NE & 178,403 & 431,968 & $1,293,973$ & $3,522,231$ & $5,426,575$ & $\mathrm{NE}$ \\
\hline ENE & 142,397 & 220,455 & $1,076,490$ & $1,449,544$ & $2,888,886$ & ENE \\
\hline$E$ & 52,020 & 121,842 & 75,175 & 0 & 249,037 & $E$ \\
\hline ESE & 38,489 & 41,729 & 135,843 & 0 & 216,061 & ESE \\
\hline SE & 14,219 & 81,760 & 179,854 & 5,852 & 281,685 & SE \\
\hline SSE & 2,926 & 13,262 & 20,520 & 36,784 & 73,492 & SSE \\
\hline S & 5,446 & 57,129 & 11,859 & 2,908 & 77,342 & $S$ \\
\hline SSW & 54,390 & 61,310 & 117,286 & 196,892 & 429,878 & SSW \\
\hline SW & 230,879 & 361,455 & $1,147,177$ & $1,032,046$ & $2,771,556$ & SW \\
\hline WSW & 52,379 & 151,542 & 311,433 & 299,453 & 814,807 & WSW \\
\hline W & 13,955 & 39,888 & 106,238 & 64,611 & 224,693 & W \\
\hline WNW & 8,287 & 12,555 & 15,439 & 252,047 & 288,328 & WNW \\
\hline NW & 13,920 & 18,653 & 66,682 & 86,917 & 186,172 & NW \\
\hline NNW & 26,092 & 13,716 & 34,241 & 22,704 & 96,753 & NNW \\
\hline Totals & $1,034,758$ & $1,890,257$ & $5,115,303$ & $7,529,287$ & $15,569,605$ & Total \\
\hline
\end{tabular}




\section{Table $13^{*}$}

1995 Population Estimates Within Annular Sectors, 10-50 Miles

\begin{tabular}{|c|c|c|c|c|c|c|}
\hline & $10-20$ & $20-30$ & $30-40$ & $40-50$ & $10-50$ & \\
\hline$\underline{\text { Sector }}$ & Miles & Miles & Miles & $\underline{\text { Miles }}$ & $\underline{\text { Miles }}$ & Sector \\
\hline$N$ & 77,600 & 43,286 & 209,880 & 82,344 & 413,110 & $\mathrm{~N}$ \\
\hline NNE & 151,656 & 244,555 & 345,449 & 501,569 & $1,243,229$ & NNE \\
\hline $\mathrm{NE}$ & 189,192 & 466,816 & $1,282,528$ & $3,531,064$ & $5,469,602$ & $\mathrm{NE}$ \\
\hline ENE & 149,614 & 244,189 & $1,075,798$ & $1,444,205$ & $2,913,807$ & ENE \\
\hline E & 48,224 & 130,379 & 80,443 & 0 & 259,046 & $\mathrm{E}$ \\
\hline ESE & 33,170 & 44,653 & 147,906 & 0 & 225,728 & ESE \\
\hline SE & 15,551 & 95,456 & 212,796 & 6,924 & 330,726 & SE \\
\hline SSE & 3,462 & 15,691 & 24,278 & 43,521 & 86,953 & SSE \\
\hline$S$ & 3,798 & 65,696 & 13,638 & 3,437 & 86,568 & $S$ \\
\hline SSW & 58,457 & 70,504 & 134,375 & 224,101 & 487,438 & SSW \\
\hline SW & 254,358 & 385,409 & $1,167,023$ & $1,035,758$ & $2,842,548$ & SW \\
\hline WSW & 55,741 & 167,298 & 319,088 & 309,761 & 851,889 & WSW \\
\hline W & 13,209 & 44,869 & 115,585 & 68,595 & 242,258 & w \\
\hline WNW & 9,332 & 14,133 & 17,280 & 265,316 & 306,061 & WNW \\
\hline NW & 15,675 & 21,005 & 72,663 & 91,959 & 201,302 & NW \\
\hline NNW & 29,653 & 15,445 & 38,640 & 25,334 & 109,071 & NNW \\
\hline Totals & $1,108,692$ & $2,069,384$ & $5,257,370$ & $7,633,889$ & $16,069,335$ & Totals \\
\hline
\end{tabular}


Table $14^{*}$

2000 Population Estimates Within Annular Sectors, 10-50 Miles

Total

\begin{tabular}{|c|c|c|c|c|c|c|}
\hline & $10-20$ & $20-30$ & $30-40$ & $40-50$ & $10-50$ & \\
\hline$\underline{\text { Sector }}$ & Miles & Miles & $\underline{\text { Miles }}$ & Miles & Miles & Sector \\
\hline $\mathrm{N}$ & 81,590 & 45,762 & 223,566 & 89,117 & 440,035 & $\mathrm{~N}$ \\
\hline NNE & 158,049 & 250,338 & 354,421 & 507,150 & $1,269,959$ & NNE \\
\hline $\mathrm{NE}$ & 193,977 & 478,786 & $1,286,928$ & $3,538,387$ & $5,498,078$ & NE \\
\hline ENE & 152,903 & 256,310 & $1,081,795$ & $1,447,794$ & $2,938,803$ & ENE \\
\hline$E$ & 47,314 & 135,772 & 83,771 & 0 & 266,857 & $E$ \\
\hline ESE & 31,627 & 46,500 & 154,983 & 0 & 233,110 & ESE \\
\hline SE & 16,320 & 102,409 & 229,267 & 7,460 & 355,455 & SE \\
\hline SSE & 3,730 & 16,906 & 26,158 & 46,890 & 93,683 & SSE \\
\hline S & 3,687 & 70,220 & 14,577 & 3,655 & 92,139 & $S$ \\
\hline SSW & 60,661 & 75,359 & 142,235 & 234,143 & 512,399 & SSW \\
\hline SW & 262,872 & 389,374 & $1,137,316$ & $1,011,964$ & $2,801,526$ & SW \\
\hline WSW & 57,234 & 172,994 & 316,136 & 311,387 & 857,751 & WSW \\
\hline W & 13,585 & 46,771 & 118,755 & 69,700 & 248,812 & w \\
\hline WNW & 10,091 & 15,112 & 18,138 & 269,393 & 312,733 & WNW \\
\hline $\mathrm{NW}$ & 16,950 & 22,713 & 75,734 & 93,637 & 209,035 & NW \\
\hline$\therefore N W$ & 31,170 & 16,701 & 40,885 & 26,602 & 115,358 & NNW \\
\hline Totals & $1,141,761$ & $2,142,027$ & $5,304,664$ & $7,657,280$ & $16,245,732$ & Totals \\
\hline
\end{tabular}


Table $15^{*}$

2010 Population Estimates Within Annular Sectors, 10-50 Miles

\begin{tabular}{|c|c|c|c|c|c|c|}
\hline & $10-20$ & $20-30$ & $30-40$ & $40-50$ & $10-50$ & \\
\hline$\underline{\text { Sector }}$ & $\underline{\text { Miles }}$ & Miles & Miles & Miles & Miles & Sector \\
\hline $\mathrm{N}$ & 91,018 & 51,262 & 250,373 & 102,263 & 494,916 & $\mathrm{~N}$ \\
\hline NNE & 172,722 & 258,877 & 362,497 & 510,423 & $1,304,520$ & NNE \\
\hline $\mathrm{NE}$ & 209,861 & 499,736 & $1,260,255$ & $3,552,301$ & $5,522,153$ & $\mathrm{NE}$ \\
\hline ENE & 164,784 & 277,228 & $1,099,303$ & $1,464,153$ & $3,005,468$ & ENE \\
\hline E & 47,676 & 140,787 & 86,865 & 0 & 275,327 & $\mathrm{E}$ \\
\hline ESE & 30,472 & 48,217 & 163,289 & 0 & 241,978 & ESE \\
\hline SE & 17,263 & 114,276 & 258,374 & 8,407 & 398,321 & SE \\
\hline SSE & 4,203 & 19,052 & 29,479 & 52,843 & 105,577 & SSE \\
\hline$S$ & 4,009 & 78,351 & 16,265 & 4,007 & 102,632 & $S$ \\
\hline SSW & 65,172 & 84,086 & 156,390 & 252,607 & 558,255 & SSW \\
\hline SW & 284,516 & 410,918 & $1,123,253$ & 998,753 & $2,817,440$ & SW \\
\hline WSW & 61,714 & 190,521 & 321,293 & 322,263 & 895,791 & WSW \\
\hline W & 15,337 & 52,386 & 128,998 & 73,884 & 270,605 & w \\
\hline WNW & 11,698 & 17,340 & 20,389 & 281,867 & 331,295 & WNW \\
\hline NW & 19,650 & 26,331 & 81,471 & 98,437 & 225,889 & NW \\
\hline NNW & 34,761 & 19,362 & 45,199 & 28,849 & 128,171 & NNW \\
\hline Totals & $1,234,856$ & $2,288,731$ & $5,403,694$ & $7,751,059$ & $16,678,339$ & Totals \\
\hline
\end{tabular}


Table 16. (Ku86b)

\section{Sectorized Population Data To 1 Mile}

\begin{tabular}{|c|c|c|c|c|c|c|}
\hline & \multirow{2}{*}{\multicolumn{5}{|c|}{ radial distances $(\mathbf{m})^{*}$}} \\
\hline & & & & 375 & $\underline{1105}$ & $\underline{2416}$ \\
\hline & $\mathrm{n}$ & 0 & 0 & 0 & 377 & 486 \\
\hline \multirow[t]{2}{*}{$S$} & nnw & 0 & 0 & 63 & 0 & 469 \\
\hline & nw & 0 & 0 & 0 & 20 & 416 \\
\hline \multirow[t]{2}{*}{$\mathrm{E}$} & wnw & 0 & 0 & 0 & 800 & 830 \\
\hline & $w$ & 0 & 0 & 103 & 0 & 1587 \\
\hline \multirow[t]{2}{*}{ C } & wsw & 0 & 0 & 116 & 192 & 749 \\
\hline & sw & 0 & 0 & 116 & 317 & 12 \\
\hline \multirow[t]{2}{*}{$T$} & SSW & 0 & 0 & 0 & 950 & 247 \\
\hline & $\mathrm{s}$ & 0 & 0 & 317 & 317 & 820 \\
\hline \multirow[t]{2}{*}{$\mathrm{O}$} & sse & 0 & 0 & 0 & 0 & 3848 \\
\hline & se & 0 & 0 & 18 & 0 & 64 \\
\hline \multirow[t]{5}{*}{$\mathbf{R}$} & ese & 0 & 0 & 73 & 0 & 60 \\
\hline & e & 0 & 0 & 73 & 0 & 30 \\
\hline & ene & 0 & 0 & 18 & 34 & 17 \\
\hline & ne & 0 & 0 & 0 & 250 & 66 \\
\hline & nne & 0 & 0 & 0 & 186 & 25 \\
\hline
\end{tabular}

* The radii shown are midpoints of the sector radial boundaries. 


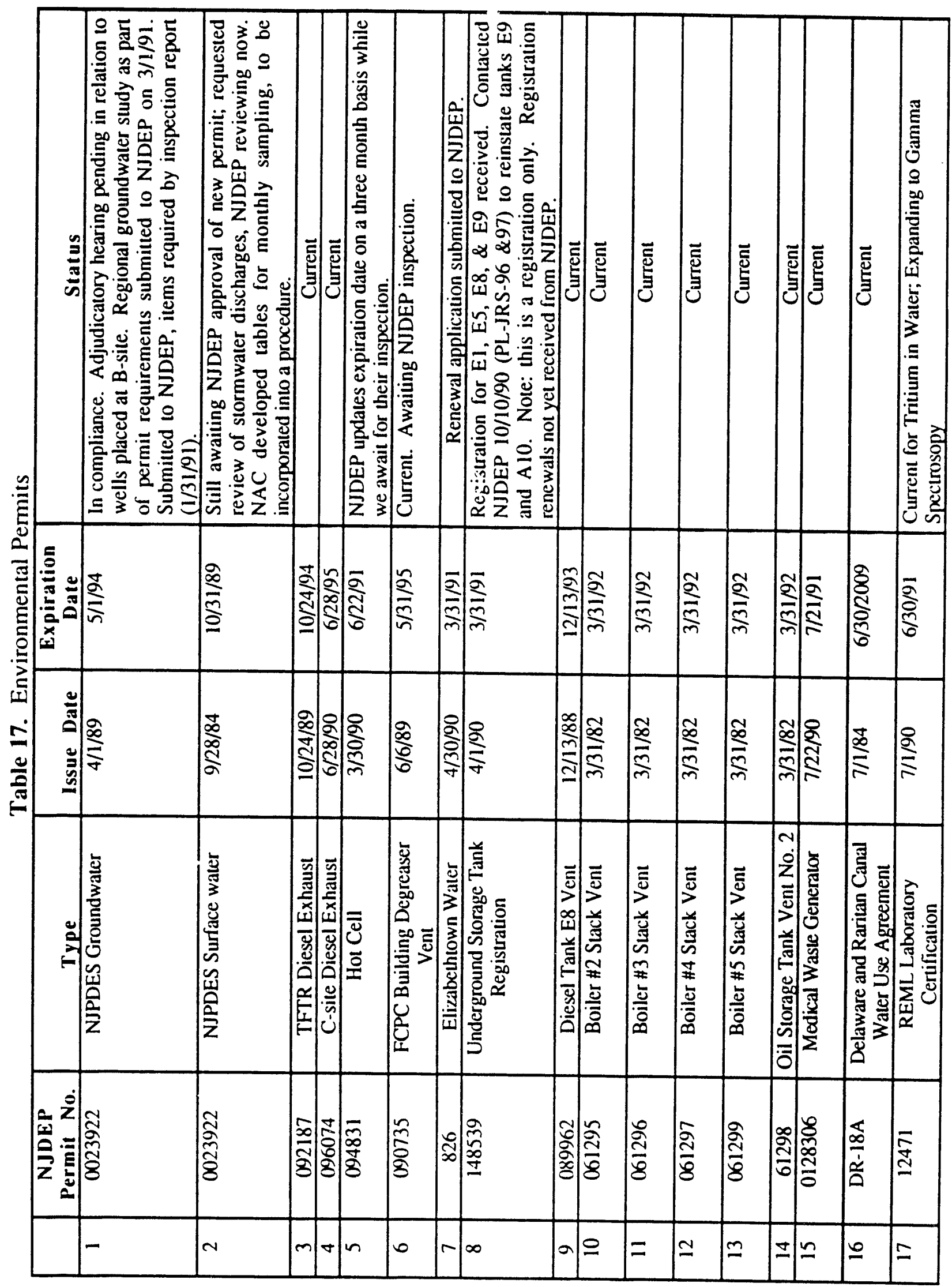


Table 18. Summary of 1990 Airborne Emissions and Doses from TFTR

\begin{tabular}{|c|c|c|c|c|}
\hline $\begin{array}{l}\text { Radionuclide } \\
\text { \& Pathway } \\
\end{array}$ & $\begin{array}{c}\text { Quantity } \\
\text { Realeased in } \\
1989^{1}\end{array}$ & $\begin{array}{l}\text { EDE at the } \\
\text { Site } \\
\text { Boundary }\end{array}$ & $\begin{array}{c}\text { EDE at the } \\
\text { Nearest } \\
\text { Business }{ }^{2}\end{array}$ & $\begin{array}{c}\text { Population Dose } \\
\text { Within } 80 \mathrm{~km}^{3}\end{array}$ \\
\hline $\begin{array}{l}\text { Tritium } \\
\text { (HTO) [air] }\end{array}$ & $1.1 \mathrm{Ci}^{4}$ & $3 \times 10^{-3}$ mrem $^{5}$ & $8 \times 10^{-4}$ mrem $^{6}$ & $4 \times 10^{-2}$ person-rem ${ }^{7}$ \\
\hline${ }^{41} \mathrm{Ar}$ & $1.9 \mathrm{Ci}^{4}$ & $2 \times 10^{-3}$ mrem $^{8}$ & $2.1 \times 10^{-3} \mathrm{mrem}$ & $1 \times 10^{-2}$ person-rem ${ }^{9}$ \\
\hline $\begin{array}{l}\text { Direct \& } \\
\text { Scattered } \\
\text { Neutrons and } \\
\text { Gamma } \\
\text { radiation }\end{array}$ & - & Background 10 & Background 10 & Background 10 \\
\hline $\begin{array}{l}\text { Tritium } \\
\text { (HTO) } \\
\text { [water] }\end{array}$ & $4.9 \times 10^{-4} \mathrm{Ci}^{11}$ & $1 \times 10^{-5} \mathrm{mrem}^{12}$ & & $\begin{array}{c}1 \times 10^{-5} \text { person- } \\
\text { rem }^{13}\end{array}$ \\
\hline Total & & $1.1 \times 1 \mathrm{C}^{-2}$ mrem & $2.9 \times 10^{-3} \mathrm{mrem}$ & $5 \times 10^{-2}$ person-rem \\
\hline Background & & 600 mrem $^{14}$ & $600 \mathrm{mrem}^{14}$ & $1.6 \times 10^{6}$ person-rem \\
\hline
\end{tabular}

Footnotes:

${ }^{1}$ Tritium \& ${ }^{41} \mathrm{Ar}$ quantities are based on production of $2.31 \times 10^{19}$ neutrons in 1990.

2 At Princeton Bank Building, 351 meters east of TFTR stack.

${ }^{3}$ Based on year 1995 population figures as utilized for Draft TFTR D-T EA. See Tables 4 [Be87a].

4 As per letter Stencel, PPPL, to Mix, DOE, on 4/15/91, "Calendar Year (CY) 1990 Air Emissions Annual Repor to the Environmental Protection Agency (EPA)," JRS-2053.

5 Based on NOAA $\chi / \mathrm{Q}\left[\mathrm{St89}\right.$ ]; $1.1 \mathrm{Ci} \times 2.6 \times 10^{-3} \mathrm{mrem} / \mathrm{Ci}$.

${ }^{6}$ Based on $28 \%$ of the NOAA $\chi / \mathrm{Q}$ at the site boundary [St89].

${ }^{7}$ Scaling from values used for the Draft TFTR D-T EA, we get $(1.1 \mathrm{Ci} / 500 \mathrm{Ci}) \times 16.2$ person-rem $=3.6 \times$ $10^{-2}$ person-rem.

${ }^{8}$ Based on NOAA X/Q [St89]; $1.9 \mathrm{Ci} \times 4.0 \times 10^{-3} \mathrm{mrem} / \mathrm{Ci}$.

${ }^{9}$ Scaling from values used for the Draft TFTR D-T EA, we get $(1.9 \mathrm{Ci} / 115 \mathrm{Ci}) \times 0.67$ person-rem $=1.0$ $\times 10^{-2}$ person-rem.

${ }^{10}$ As per "PPPL Ionizing Radiation Report for Calendar Year 1990," [Gi91].

11 Released from Liquid Effluent Collection Tanks (LECT) to Stony Brook Sewage Authority treatment facility via PPPL sanitary sewer system.

12 Based on usage of $1 \times 10^{10}$ liters/y for Stony Brook treatment facility, as per Draft TFTR D-T EA, the dose to a person who drank all his/her water from the waterway (Milstone River) into which the treatment facility discharged in 1990 would be $\left[\left(4.9 \times 10^{-4} \mathrm{Ci} / \mathrm{y}\right) /\left(1 \times 10^{10}\right.\right.$ liters $\left.\left./ \mathrm{y}\right)\right] \times\left[(4 \mathrm{mrem}) /\left(2 \times 10^{-8}\right.\right.$ $\mathrm{Ci} /$ iter $)]=1 \times 10^{-5} \mathrm{mrem}$.

13 Based on use of Millstone River as drinking water source for 500,000 people for 1 day per year (estimate by Elizabethtown Water Company of actual use is a few hours once every several years).

14 Based on 100 mrem annual background dose exclusive of radon, plus dose due to exposure to average radon concentration in Plainsboro homes (Memo, J. Greco to J. Levine, 11/13/90, "Radon Dose Equivalent," JMG-160). 
Table 19. Tritium in Precipitation for 1990

\begin{tabular}{|c|c|c|}
\hline $\begin{array}{c}\text { Precipitation } \\
\text { Collection Dates }\end{array}$ & Period & $\begin{array}{c}{ }^{3} \mathrm{H} \text { Concentration } \\
\mathrm{pCi} / \text { liter }\end{array}$ \\
\hline Jan. 1-8 & 1 & No Analysis \\
\hline $\operatorname{Jan} .8-15$ & 2 & 44 \\
\hline $\operatorname{Jan} 15-22$ & $\overline{3}$ & 47 \\
\hline $\operatorname{Jan} 22-29$ & 4 & 54 \\
\hline $\operatorname{Jan} 29-$ Feb 2 & 5 & 21 \\
\hline Feb $2-13$ & 6 & 47 \\
\hline Feb 13-19 & 7 & No Analysis \\
\hline Feb 19-26 & $\overline{8}$ & 41 \\
\hline Feb 26 - Mar 5 & 9 & No Analysis \\
\hline Mar 5-12 & 10 & No Analysis \\
\hline $\operatorname{Mar} 12-19$ & 11 & 19 \\
\hline Mar 19-26 & 12 & 34 \\
\hline Mar 26-Apr 2 & $\overline{13}$ & 29 \\
\hline Apr 2-9 & 14 & 45 \\
\hline Apr 9-16 & 15 & 23 \\
\hline Apr $16-23$ & 16 & 48 \\
\hline Apr 23-30 & 17 & 38 \\
\hline Apr $30-$ May 7 & 18 & 49 \\
\hline May 7-14 & 19 & 21 \\
\hline May 14-21 & 20 & 59 \\
\hline May 21-29 & 21 & 50 \\
\hline May 29 - Jun 4 & 22 & 34 \\
\hline Jun $4-11$ & 23 & 38 \\
\hline Jun $11-18$ & 24 & 53 \\
\hline Jun $18-25$ & 25 & 43 \\
\hline Jun 25 - Jul 16 & 26 & No Analysis \\
\hline Jul $16-23$ & 27 & 37 \\
\hline Jul $23-30$ & 28 & 37 \\
\hline Jul 30 - Aug 6 & 29 & 94 \\
\hline Aug 6-13 & 30 & 65 \\
\hline Aug $13-20$ & 31 & No Analysis \\
\hline Aug $20-27$ & 32 & 21 \\
\hline Sep 4-10 & 33 & No Rain \\
\hline Sep $10-17$ & 34 & 92 \\
\hline Sep $17-24$ & 35 & 54 \\
\hline Sep 24- Oct 1 & 36 & 60 \\
\hline Oct $1-8$ & 37 & 45 \\
\hline Oct $8-15$ & 38 & 28 \\
\hline Oct $15-22$ & 39 & 25 \\
\hline Oct $22-29$ & 40 & 14 \\
\hline Oct $29-$ Nov 5 & 41 & No Rain \\
\hline Nov $5-12$ & 42 & No Analysis \\
\hline Nov $12-19$ & 43 & 85 \\
\hline Nov $19-26$ & 44 & 91 \\
\hline Nov $26-\operatorname{Dec} 3$ & +5 & No Rain \\
\hline $\operatorname{Dec} 3-\operatorname{Jan} 21991$ & 46 & No Analysis \\
\hline
\end{tabular}


Table 20. Precipitation at PPPL for 1990

\begin{tabular}{|c|c|c|c|c|c|}
\hline Week & Start Date & Inches & Inch/Month & Month & Accumulation \\
\hline 1 & 1-Jan & 0.000 & & & 0.000 \\
\hline 2 & 6-Jan & 0.950 & & & 0.950 \\
\hline 3 & 15-Jan & 0.600 & & & 1.550 \\
\hline 4 & 22-Jan & 1.450 & & & 3.000 \\
\hline 5 & 29-Jan & 1.500 & 4.500 & Jan & 4.500 \\
\hline 6 & 5-Feb & 0.800 & & & 5.300 \\
\hline 7 & 12-Feb & 0.050 & & & 5.350 \\
\hline 8 & 19.Feb & 0.550 & & & 5.900 \\
\hline 9 & 26-Feb & 0.000 & 1.400 & Feb & 5.900 \\
\hline 10 & 5-Mar & 0.140 & & & 6.040 \\
\hline 11 & 12-Mar & 1.000 & & & 7.040 \\
\hline 12 & 19-Mar & 0.550 & & & 7.590 \\
\hline 13 & 26-Mar & 0.590 & 2.280 & Mar & 8.180 \\
\hline 14 & 2-Apr & 1.350 & & & 9.530 \\
\hline 15 & 9-Apr & 1.505 & & & 11.035 \\
\hline 16 & 16-Apr & 0.340 & & & 11.375 \\
\hline 17 & 23-Apr & 0.315 & 3.510 & Apr & 11.690 \\
\hline 18 & 7-May & 1.470 & & & 13.160 \\
\hline 19 & 14-May & 1.995 & & & 15.155 \\
\hline 20 & 21-May & 2.125 & & & 17.280 \\
\hline 21 & 28-May & 0.700 & 6.290 & May & 17.980 \\
\hline 22 & 4-June & 2.580 & & & 20.560 \\
\hline 23 & 11-June & 1.100 & & & 21.660 \\
\hline 24 & 18-June & 0.500 & & & 22.160 \\
\hline 25 & 25-June & 2.250 & 6.430 & June & 24.410 \\
\hline 26 & 2-July & 0.680 & & & 25.090 \\
\hline 27 & 9-July & 0.450 & & & 25.540 \\
\hline 28 & 16-July & 2.235 & & & 27.775 \\
\hline 29 & 23-July & 0.810 & & & 28.585 \\
\hline 30 & 30-July & 0.450 & 4.625 & July & 29.035 \\
\hline 31 & 6-Aug & 2.750 & & & 31.785 \\
\hline 32 & 13-Aug & 3.650 & & & 35.435 \\
\hline 33 & 20-Aug & 0.550 & & & 35.985 \\
\hline 34 & 27-Aug & 0.525 & 7.475 & Aug & 36.510 \\
\hline 35 & 3-Sept & 0.725 & & & 37.235 \\
\hline 36 & 10-Sept & 0.000 & & & 37.235 \\
\hline 37 & 17-Sept & 0.725 & & & 37.960 \\
\hline 38 & 24-Sept & 1.000 & 2.450 & Sept & 38.960 \\
\hline 39 & $1-0 \mathrm{ct}$ & 0.675 & & & 39.635 \\
\hline 40 & $8-0 \mathrm{ct}$ & 0.250 & & & 39.885 \\
\hline 41 & $15-\mathrm{Oct}$ & 0.900 & & & 40.785 \\
\hline 42 & $22-O c t$ & 1.175 & & & 41.960 \\
\hline 43 & $29-\mathrm{Oct}$ & 0.850 & 3.850 & Oct & 42.810 \\
\hline 44 & 5-Nov & 0.000 & & & 42.810 \\
\hline 45 & 12-Nov & 1.450 & & & 44.260 \\
\hline 46 & 19-Nov & 0.300 & & & 44.560 \\
\hline 47 & 26-Nov & 0.225 & 1.975 & Nov & 44.785 \\
\hline 48 & 3-Dec & 0.000 & & & 44.785 \\
\hline 49 & 10-Dec & 1.575 & & & 46.360 \\
\hline 50 & 17-Dec & 1.075 & & & 47.435 \\
\hline 51 & 24-Dec & 1.850 & & & 49.285 \\
\hline $5 \overline{2}$ & 31-Dec & 1.050 & 5.550 & Dec & 50.335 \\
\hline
\end{tabular}


Table 21. Tritium Concentrations in Surface Water and Groundwater for $1990^{*}$

Surface Water (See Fig. 31 for Location)

\begin{tabular}{|r|r|r|r|r|r|r|r|r|r|}
\hline $\begin{array}{r}\text { Location-> } \\
\begin{array}{c}\text { Collection } \\
\text { Date }\end{array}\end{array}$ & B1 & B2 & C1 & D1 & D2 & E1 & M1 & P1 & P2 \\
\hline $1 / 9 / 90$ & 38 & 40 & frozen & 35 & 39 & 52 & 50 & 53 & 51 \\
\hline $2 / 1 / 90$ & 51 & 48 & 50 & 50 & 54 & 49 & 44 & 43 & 39 \\
\hline $2 / 20 / 90$ & 49 & 49 & 55 & 49 & 47 & 48 & 49 & 53 & 54 \\
\hline $3 / 13 / 90$ & 48 & 50 & 52 & 51 & 50 & 50 & 58 & 57 & 55 \\
\hline $4 / 9 / 90$ & 44 & 45 & 46 & 48 & 49 & 48 & 46 & 64 & 57 \\
\hline $5 / 2 / 90$ & 54 & 53 & 62 & 62 & 60 & 56 & 56 & 59 & 54 \\
\hline $5 / 31 / 90$ & No Analysis & NoAnalysis & 41 & 53 & 51 & 47 & 36 & 38 & 35 \\
\hline $6 / 22 / 90$ & 51 & 52 & 52 & 55 & 53 & 56 & 55 & 62 & 49 \\
\hline $7 / 11 / 90$ & 53 & 46 & 56 & 55 & 62 & 57 & 52 & 52 & 52 \\
\hline $8 / 1 / 90$ & 57 & 53 & 61 & 52 & No Analysis & 60 & 49 & 55 & 53 \\
\hline $8 / 31 / 90$ & 52 & 52 & 72 & 57 & 55 & 55 & 49 & 66 & 54 \\
\hline $9 / 11 / 90$ & 51 & 57 & 62 & 63 & 62 & 61 & 57 & 57 & 60 \\
\hline $10 / 8 / 90$ & 50 & 55 & 61 & 57 & 61 & 61 & 51 & 60 & 63 \\
\hline $11 / 6 / 90$ & 42 & 46 & 61 & 56 & 52 & 54 & 47 & 61 & 49 \\
\hline $11 / 28 / 90$ & 38 & 48 & 50 & 53 & 54 & 55 & 46 & 62 & 50 \\
\hline
\end{tabular}

Groundwater Wells (See Fig. 20 for Locations)

\begin{tabular}{|c|r|r|r|r|r|r|r|r|r|}
\hline Location-> & TW1 & TW10 & TW3 & D11 & D12 & \#W4 & \#W5 & & \\
\hline $\begin{array}{c}\text { Collection } \\
\text { Date }\end{array}$ & & & & & & & & & \\
\hline $3 / 13 / 90$ & 56 & 63 & No Sample & No Sample & No Sample & No Sample & No Sample & & \\
\hline $5 / 290$ & 52 & 56 & 46 & 49 & 53 & No Sample & No Sample & & \\
\hline $5 / 31 / 90$ & 50 & 53 & 48 & No Sample & No Sample & 50 & 53 & & \\
\hline $8 / 31 / 90$ & No Sample & No Sample & 57 & 56 & 53 & No Sample & No Sample & & \\
\hline
\end{tabular}

Table 22. Tritium Concentrations in Soil/Sod Moisture for 1990

\begin{tabular}{|c|r|r|r|r|r|r|r|r|r|}
\hline Location--> & S11 & S12 & S13 & S14 & S15 & S16 & S17 & S18 & S19 \\
\hline $\begin{array}{c}\text { Collection } \\
\text { Date }\end{array}$ & & & & & & & & & \\
\hline $3 / 27 / 90$ & 45 & 41 & 44 & $\cdots$ & 41 & 47 & 49 & 47 & 47 \\
\hline $6 / 26 / 90$ & 46 & 49 & 45 & $\cdots$ & & 47 & 48 & 44 & 49 \\
\hline $9 / 5 / 90$ & 69 & 72 & 67 & $\cdots$ & 72 & 63 & 73 & 65 & 68 \\
\hline $10 / 10 / 90$ & 73 & 65 & 68 & $\cdots$ & 60 & 66 & 70 & No Analysis & No Analyssis \\
\hline
\end{tabular}

** = Sample not taken; soil disruption due to road construction.

* All measurement valucs are in pCi/fiter. 
Tables 23. Surface Water Analysis for Bee Brook, Location B1.

\begin{tabular}{|c|c|c|c|c|c|c|c|}
\hline & Collection Date & $1 / 23 / 90$ & $2 / 20 / 90$ & $3 / 22 / 90$ & $4 / 24 / 90$ & $5 / 23 / 90$ & $8 / 20 / 90$ \\
\hline Units & Parameter & & & & & & \\
\hline $\mathrm{mg} / \mathrm{CaCO} \mathrm{Cag}_{3}$ & Alkalinity & 32 & 10 & 23 & 50 & & \\
\hline $\mathrm{mg} / \mathrm{l} \mathrm{O}$ & BOD5 & $<1.0$ & 2 & $<1.0$ & 4.1 & 1.9 & 2.3 \\
\hline $\mathrm{mg} / \mathrm{CaCO} \mathrm{Cg}_{3}$ & $\begin{array}{l}\text { Calcium } \\
\text { Hardness }\end{array}$ & 25 & 11 & 27 & 4.0 & & \\
\hline $\mathrm{mg} / \mathrm{l} \mathrm{Cr}$ & $\begin{array}{l}\text { Chromium - } \\
\text { Total }\end{array}$ & $<0.02$ & $<0.02$ & $<0.02$ & $<0.020$ & $<0.02$ & $<0.02$ \\
\hline $\mathrm{mg} / \mathrm{Cr}$ & $\begin{array}{l}\text { Chromium - } \\
\text { Hexavalent }\end{array}$ & $<0.02$ & $<0.02$ & $<0.02$ & $<0.02$ & & \\
\hline $\mathrm{mg} / \mathrm{l} \mathrm{O}$ & COD & $<5.0$ & $<5.0$ & $<5.0$ & $<5.0$ & $<5.0$ & 13 \\
\hline $\mathrm{mg} / \mathrm{l} \mathrm{Cu}$ & Copper & $<0.02$ & $<0.02$ & $<0.02$ & $<0.025$ & & \\
\hline $\mathrm{mg} / \mathrm{l} \mathrm{O} 2$ & $\begin{array}{l}\text { Dissolved } \\
\text { Oxygen }\end{array}$ & 9.9 & 13.2 & 11 & 9.6 & & \\
\hline $\mathrm{mg} / \mathrm{l} \mathrm{Cu} \mathrm{eq.}$ & EDTA & $<0.02$ & 0.30 & 0.83 & 1.0 & & \\
\hline$M P N / 100 \mathrm{ml}$ & $\begin{array}{l}\text { Total Coliform } \\
\text { Count }\end{array}$ & 70 & 8 & 280 & 240 & & \\
\hline $\mathrm{ft}^{3} / \mathrm{sec}$ & Flow & 0.15 & 0.13 & 0.25 & 0.13 & 0.1 & 0.05 \\
\hline $\mathrm{mg} / \mathrm{IFe}$ & Iron & 0.55 & 0.21 & 0.30 & 0.28 & & \\
\hline $\mathrm{mg} / \mathrm{l}$ & $\begin{array}{l}\text { Nitrogen, } \\
\text { Ammonia }\end{array}$ & & & & & 0.73 & $<0.10$ \\
\hline $\mathrm{mg} / \mathrm{l} \mathrm{N}$ & $\begin{array}{l}\text { Nitrogen, Total } \\
\text { Kjedahl }\end{array}$ & $<0.10$ & 1.3 & 0.67 & 0.28 & & \\
\hline $\mathrm{mg} / \mathrm{l} \mathrm{N}$ & $\begin{array}{l}\text { Nitrogen, } \\
\text { Nitrate }\end{array}$ & 0.12 & 1.1 & 0.98 & 0.65 & & \\
\hline $\mathrm{mg} / \mathrm{l}$ & Oil \& Grease & $<0.50$ & 0.9 & $<0.5$ & $<0.050$ & & \\
\hline Unit & $\mathrm{pH}$ & 6.6 & 7.0 & 7.4 & 8.6 & 6.7 & 7.2 \\
\hline $\mathrm{mg} / \mathrm{l}$ & $\begin{array}{l}\text { Petroleum } \\
\text { Hydrocarbons, } \\
\text { Total }\end{array}$ & & & & & $<0.5$ & $<0.50$ \\
\hline $\mathrm{mg} / \mathrm{l}$ & Phenols, Total & & & & & $<0.10$ & $<0.10$ \\
\hline $\mathrm{mg} / \mathrm{P}$ & $\begin{array}{l}\text { Phosphate, } \\
\text { Total }\end{array}$ & $<0.1$ & $<0.1$ & $<0.1$ & $<0.1$ & & \\
\hline$m g / l p$ & $\begin{array}{l}\text { Phosphate, } \\
\text { Ortho }\end{array}$ & $<0.1$ & $<0.1$ & $<0.1$ & 0.4 & & \\
\hline $\mathrm{mg} / \mathrm{l}$ & $\begin{array}{l}\text { Solids - } \\
\text { Dissolved }\end{array}$ & 176 & 124 & 95 & 139 & 106 & 113 \\
\hline $\mathrm{mg} / \mathrm{l}$ & $\begin{array}{l}\text { Solids - } \\
\text { Setteable }\end{array}$ & & & & & $<0.10$ & \\
\hline $\mathrm{mg} / 1$ & $\begin{array}{l}\text { Solids - } \\
\text { Suspended }\end{array}$ & 1 & 5 & 7 & 6 & & 5 \\
\hline $\mathrm{mg} / \mathrm{/} \mathrm{SO} 4$ & Sulfate & 20 & 15 & 22 & 15 & & \\
\hline Deg C & Temperature & 5 & 6 & 12 & 16 & & \\
\hline NTU & Turbidity & 3.1 & 4.8 & 3.6 & 6.3 & & \\
\hline $\mathrm{mg} / \mathrm{l} \mathrm{Zn}$ & Zinc & $<0.02$ & $<0.02$ & $<0.02$ & $<0.02$ & & \\
\hline & Clarity & Clear & Clear & Clear & Cloudy & & \\
\hline
\end{tabular}


Table 24. Surface Water Analysis for Bee Brook, Location B2.

\begin{tabular}{|c|c|c|c|c|c|c|c|}
\hline & Collection Date & $1 / 23 / 90$ & $2 / 20 / 90$ & $3 / 22190$ & $4 / 24 / 90$ & $5 / 23 / 90$ & $8 / 20 / 90$ \\
\hline Units & Parameter & & & & & & \\
\hline $\mathrm{mg} / \mathrm{CaCO} \mathrm{Cag}_{3}$ & Alkalinity & 22 & 17.2 & 23 & 37 & & \\
\hline $\mathrm{mg} / \mathrm{l} \mathrm{O2}$ & BOD5 & $<1.0$ & $<1$ & $<1$ & 3.5 & 2.4 & 3.7 \\
\hline $\mathrm{mg} / \mathrm{CaCO}_{3} \mathrm{eq}$. & $\begin{array}{l}\text { Calcium } \\
\text { Hardness }\end{array}$ & 30 & 20 & 28 & 40 & & \\
\hline $\mathrm{mg} / \mathrm{l} \mathrm{Cr}$ & $\begin{array}{l}\text { Chromium - } \\
\text { Total }\end{array}$ & $<0.02$ & $<0.02$ & $<0.02$ & $<0.02$ & $<0.02$ & $<0.02$ \\
\hline $\mathrm{mg} / \mathrm{l} \mathrm{Cr}$ & $\begin{array}{l}\text { Chromium - } \\
\text { Hexavalent }\end{array}$ & $<0.02$ & $<0.02$ & $<0.02$ & $<0.02$ & & \\
\hline $\mathrm{mg} / \mathrm{l} \mathrm{O}$ & COD & $<5.0$ & $<5.0$ & 10 & $<5.0$ & 17 & 18 \\
\hline $\mathrm{mg} / \mathrm{l} \mathrm{Cu}$ & Copper & $<0.02$ & $<0.02$ & $<0.02$ & $<0.025$ & & \\
\hline $\mathrm{mg} / \mathrm{l} \mathrm{O}_{2}$ & $\begin{array}{l}\text { Dissolved } \\
\text { Oxygen }\end{array}$ & 10.3 & 13 & 11.7 & 10.2 & & \\
\hline $\mathrm{mg} / \mathrm{l} \mathrm{Cu}$ eq. & EDTA & 0.23 & 0.8 & 0.77 & 80 & & \\
\hline$M P N / 100 \mathrm{ml}$ & $\begin{array}{l}\text { Total Coliform } \\
\text { Count }\end{array}$ & 90 & 23 & $<1600$ & 0.72 & & \\
\hline $\mathrm{ft}^{3} / \mathrm{sec}$ & Flow & 0.12 & 0.17 & 0.28 & 0.2 & 0.2 & 0.1 \\
\hline $\mathrm{mg} / \mathrm{Fe}$ & Iron & 0.46 & 0.2 & 0.22 & 0.285 & & \\
\hline $\mathrm{mg} / 1$ & $\begin{array}{l}\text { Nitrogen, } \\
\text { Ammonia } \\
\end{array}$ & & & & & 0.2 & $<0.10$ \\
\hline $\mathrm{mg} / \mathrm{N} \mathrm{N}$ & $\begin{array}{l}\text { Nitrogen, Total } \\
\text { Kjedahl }\end{array}$ & 0.87 & 1 & 1.1 & 0.95 & & \\
\hline $\mathrm{mg} / \mathrm{l} \mathrm{N}$ & $\begin{array}{l}\text { Nitrogen, } \\
\text { Nitrate }\end{array}$ & 0.85 & 1.2 & 1.5 & 0.55 & & \\
\hline $\mathrm{mg} / \mathrm{l}$ & Oil \& Grease. & $<0.5$ & $<0.5$ & $<0.5$ & $<0.5$ & & \\
\hline unit & $\mathrm{pH}$ & 6.8 & 7.1 & 7.3 & 9 & 6.9 & 7.4 \\
\hline $\mathrm{mg} / 1$ & $\begin{array}{l}\text { Petroleum } \\
\text { Hydrocarbons, } \\
\text { Total }\end{array}$ & & & & & $<0.50$ & $<0.50$ \\
\hline $\mathrm{mg} / \mathrm{l}$ & Phenols, Total & & & & & $<0.10$ & $<0.10$ \\
\hline $\mathrm{mg} / \mathrm{l} P$ & $\begin{array}{l}\text { Phosphate, } \\
\text { Total } \\
\end{array}$ & 0.2 & $<0.1$ & $<0.1$ & $<0.1$ & & \\
\hline $\mathrm{mg} / \mathrm{l} P$ & $\begin{array}{l}\text { Phosphate, } \\
\text { Ortho } \\
\end{array}$ & $<0.10$ & $<0.1$ & $<0.1$ & $<0.1$ & & \\
\hline $\mathrm{mg} / \mathrm{l}$ & $\begin{array}{l}\text { Solids - } \\
\text { Dissolved } \\
\end{array}$ & 181 & 78 & 97 & 136 & 118 & 119 \\
\hline $\mathrm{mg} / \mathrm{l}$ & \begin{tabular}{|l|} 
Solids - \\
Setteable \\
\end{tabular} & & & & & $<0.10$ & \\
\hline $\mathrm{mg} / \mathrm{l}$ & $\begin{array}{l}\text { Solids - } \\
\text { Suspended }\end{array}$ & 2 & 6 & 6 & 10 & & 2 \\
\hline $\mathrm{mg} / \mathrm{l} \mathrm{SO}$ & Sulfate & 26 & 16 & 29 & 195 & & \\
\hline$D e g C$ & Temperature & 6 & 5 & 11.5 & 16 & & \\
\hline NTU & \begin{tabular}{|l} 
Turbidity \\
\end{tabular} & 4.4 & 4 & 5.5 & 5 & & \\
\hline $\mathrm{mg} / \mathrm{l} \mathrm{Zn}$ & Zinc & $<0.02$ & $<0.02$ & $<0.02$ & 0.022 & & \\
\hline & Clarity & Clear & Clear & Clear & Clear & & \\
\hline
\end{tabular}


Table 25. Surface Water Analysis for D\&R Canal, Location C1.

\begin{tabular}{|c|c|c|c|c|c|c|c|}
\hline & Collection Date & $1 / 23 / 90$ & $2 / 20 / 90$ & $3 / 22 / 90$ & $4 / 24 / 90$ & $5 / 23 / 90$ & $8 / 20 / 90$ \\
\hline Units & Parameter & & & & & & \\
\hline $\mathrm{mg} / \mathrm{CaCO}$ eq. & Alkalinity & 41 & 15 & 30 & 34 & & \\
\hline $\mathrm{mg} / \mathrm{O} \mathrm{O}_{2}$ & $\mathrm{BOD}_{5}$ & & & & & 2.1 & 2.4 \\
\hline $\mathrm{mg} / \mathrm{CaCO} \mathrm{Cg}_{3}$ & $\begin{array}{l}\text { Calcium } \\
\text { Hardness }\end{array}$ & 40 & 28 & 33 & 35 & & \\
\hline $\mathrm{mg} / \mathrm{Cr}$ & $\begin{array}{l}\text { Chromium - } \\
\text { Total }\end{array}$ & $<0.02$ & $<0.02$ & $<0.02$ & $<0.02$ & & \\
\hline $\mathrm{mg} / \mathrm{l} \mathrm{Cr}$ & $\begin{array}{l}\text { Chromium - } \\
\text { Hexavalent } \\
\end{array}$ & $<0.02$ & $<0.02$ & $<0.02$ & & & \\
\hline $\mathrm{mg} / 1 \mathrm{O}_{2}$ & COD & & & & & $<5.0$ & 17 \\
\hline $\mathrm{mg} / \mathrm{Cu}$ & Copper & $<0.02$ & $<0.02$ & $<0.02$ & $<0.025$ & & \\
\hline $\mathrm{mg} / \mathrm{Cu}$ eq. & EDTA & $<0.02$ & 0.26 & 0.76 & 0.2 & & \\
\hline $\mathrm{mg} / \mathrm{Fe}$ & Iron & 0.28 & 0.5 & 0.29 & 0.26 & & \\
\hline $\mathrm{mg} / \mathrm{l}$ & \begin{tabular}{|l|} 
Nitrogen, \\
Ammonia \\
\end{tabular} & & & & & 0.31 & $<0.10$ \\
\hline $\mathrm{rng} / \mathrm{N}$ & \begin{tabular}{|l|} 
Nitrogen, \\
Nitrate \\
\end{tabular} & 1.8 & 3.0 & 2.2 & 1.1 & & \\
\hline $\mathrm{mg} / \mathrm{l}$ & Oil \& Grease & $<0.5$ & 0.9 & $<0.5$ & $<0.5$ & & \\
\hline unit & $\mathrm{pH}$ & 7.1 & 7 & $\overline{7}$ & 7.1 & 6.6 & 7.2 \\
\hline $\mathrm{mg} / \mathrm{l}$ & $\begin{array}{l}\text { Petroleum } \\
\text { Hydrocarbons, } \\
\text { Total }\end{array}$ & & & & & $<0.5$ & $<0.5$ \\
\hline $\mathrm{mg} / \mathrm{l}$ & Phenols, Total & & & & & 0.1 & $<0.10$ \\
\hline $\mathrm{mg} / \mathrm{P}$ & $\begin{array}{l}\text { Phosphate, } \\
\text { Total }\end{array}$ & $<0.1$ & 0.1 & $<0.1$ & $<0.1$ & & \\
\hline $\mathrm{mg} / \mathrm{P}$ & $\begin{array}{l}\text { Phosphate, } \\
\text { Ortho }\end{array}$ & $<0.1$ & $<0.1$ & $<0.1$ & $<0.1$ & & \\
\hline $\mathrm{mg} / \mathrm{l}$ & \begin{tabular}{|l|} 
Solids - \\
Dissolved \\
\end{tabular} & 123 & 117 & 118 & 105 & 100 & 107 \\
\hline $\mathrm{mg} !$ & $\begin{array}{l}\text { Solids - } \\
\text { Setteable } \\
\end{array}$ & & & & & 0.10 & \\
\hline $\mathrm{mg} / \mathrm{l}$ & \begin{tabular}{|l|} 
Solids - \\
Suspended \\
\end{tabular} & $<1.0$ & 11 & 23 & 11 & & 27 \\
\hline $\mathrm{mg} / \mathrm{SO}_{4}$ & \begin{tabular}{|l} 
Sulfate \\
\end{tabular} & 20 & 20 & 31 & 17 & & \\
\hline NTU & \begin{tabular}{|l} 
Turbidity \\
Tri
\end{tabular} & 4.9 & 8.8 & 9.5 & 9.1 & & \\
\hline $\mathrm{mg} / \mathrm{Zn}$ & Zinc & $<0.02$ & $<0.02$ & $<0.02$ & $<0.020$ & & \\
\hline & Clarity & Clear & $\begin{array}{l}\text { Slightly } \\
\text { Cloudy }\end{array}$ & Clear & Clear & & \\
\hline
\end{tabular}


Table 26. Surface Water Analysis for Ditch \#5, Location D1.

\begin{tabular}{|c|c|c|c|c|c|c|c|}
\hline & Collection Date & $1 / 23 / 90$ & $2 / 20 / 90$ & $3 / 22 / 90$ & $4 / 24 / 90$ & $5 / 23 / 90$ & $8 / 20 / 90$ \\
\hline Units & Parameter & & & & & & \\
\hline $\mathrm{mg} / \mathrm{CaCO} \mathrm{Cag}_{3}$ & Alkalinity & 34 & 23 & 31 & 28 & & \\
\hline $\mathrm{mg} / \mathrm{l} \mathrm{O}$ & $\mathrm{BOD}_{5}$ & $<1.0$ & $<1$ & $<1$ & 2.9 & 24 & 7 \\
\hline $\mathrm{mg} / \mathrm{CaCO} \mathrm{Ca}_{3}$ eq. & $\begin{array}{l}\text { Calcium } \\
\text { Hardness }\end{array}$ & 40 & 32 & 50 & 36 & & \\
\hline $\mathrm{mg} / \mathrm{l} \mathrm{Cr}$ & $\begin{array}{l}\text { Chromium - } \\
\text { Total }\end{array}$ & $<0.02$ & $<0.02$ & $<0.02$ & $<0.02$ & $<0.02$ & $<0.02$ \\
\hline $\mathrm{mg} / \mathrm{l} \mathrm{Cr}$ & $\begin{array}{l}\text { Chromium - } \\
\text { Ho:iavalent }\end{array}$ & $<0.02$ & $<0.02$ & 0.02 & $<0.02$ & & \\
\hline $\mathrm{mg} / \mathrm{l} \mathrm{O}$ & $\mathrm{COD}$ & $<5.0$ & $<5.0$ & $<5.0$ & $<5.0$ & 25 & 19 \\
\hline $\mathrm{mg} / \mathrm{l} \mathrm{Cu}$ & Copper & $<0.02$ & $<0.02$ & $<0.02$ & 0.025 & & \\
\hline $\mathrm{mg} / \mathrm{l} \mathrm{O}$ & $\begin{array}{l}\text { Dissolved } \\
\text { Oxygen } \\
\end{array}$ & 9.6 & 10.9 & 9.9 & 9.1 & & \\
\hline $\mathrm{mg} / \mathrm{l} \mathrm{Cu} \mathrm{eq}$. & EDTA & $<0.02$ & 0.28 & 0.31 & 0.32 & & \\
\hline MPN/100 ml & $\begin{array}{l}\text { Total Coliform } \\
\text { Count }\end{array}$ & 900 & $<2$ & $<2$ & $<2.0$ & & \\
\hline $\mathrm{ft}^{3} / \mathrm{sec}$ & Flow & 0.05 & 0.05 & 0.06 & 0.08 & 0.5 & 0.03 \\
\hline $\mathrm{mg} / \mathrm{l} \mathrm{Fe}$ & Iron & 0.23 & 0.15 & 0.14 & 0.282 & & \\
\hline $\mathrm{mg} / 1$ & $\begin{array}{l}\text { Nitrogen, } \\
\text { Ammonia } \\
\end{array}$ & & & & & 0.31 & $<0.10$ \\
\hline $\mathrm{mg} / \mathrm{N}$ & $\begin{array}{l}\text { Nitrogen, Total } \\
\text { Kiedahl }\end{array}$ & 0.95 & 0.6 & 1.3 & 1.2 & & \\
\hline $\mathrm{mg} / \mathrm{N}$ & $\begin{array}{l}\text { Nitrogen, } \\
\text { Nitrate }\end{array}$ & 2.5 & 1.9 & 2.9 & 1.2 & & \\
\hline $\mathrm{mg} / \mathrm{l}$ & Oil \& Grease & 1.1 & 0.6 & $<0.5$ & $<0.5$ & & \\
\hline unit & $\mathrm{pH}$ & 7 & 6.8 & 7 & 7 & 6.6 & 7 \\
\hline $\mathrm{mg} / \mathrm{l}$ & $\begin{array}{l}\text { Petroleum } \\
\text { Hydrocarbons, } \\
\text { Total }\end{array}$ & & & & & $<0.50$ & $<0.50$ \\
\hline $\mathrm{mg} / \mathrm{l}$ & Phenols. Total & & & & & $<0.10$ & $<0.10$ \\
\hline $\mathrm{mg} / \mathrm{P}$ & $\begin{array}{l}\text { Phosphate, } \\
\text { Total }\end{array}$ & 0.5 & C 5 & $<0.1$ & 0.5 & & \\
\hline $\mathrm{mg} / \mathrm{P}$ & $\begin{array}{l}\text { Phosphate, } \\
\text { Orino }\end{array}$ & 0.1 & $0 . \overline{1}$ & $<0.1$ & 0.2 & & \\
\hline $\mathrm{mg} / 1$ & $\begin{array}{l}\text { Solids - } \\
\text { Dissolved }\end{array}$ & 135 & 138 & 157 & 104 & & $\begin{array}{l}1 \\
34 \\
\end{array}$ \\
\hline $\mathrm{mg} / 1$ & $\begin{array}{l}\text { Solids - } \\
\text { Setteable }\end{array}$ & & & & & 132 & $<0.10$ \\
\hline $\mathrm{mg} / \mathrm{l}$ & $\begin{array}{l}\text { Solids - } \\
\text { Suspended }\end{array}$ & $<1.0$ & 3 & 7 & 4 & & \\
\hline $\mathrm{mg} / / \mathrm{SO}_{4}$ & Sulfate & 24 & 18 & 3 & 19 & & \\
\hline $\mathrm{DegC}$ & Temperature & 12 & 12 & 13 & 14 & & \\
\hline NTU & Turbidity & 3.9 & 2.9 & 0.65 & 7.1 & & \\
\hline $\mathrm{mg} / \mathrm{l} \mathrm{Zn}$ & Zinc & $<0.02$ & $<0.02$ & $<0.02$ & $<0.020$ & & \\
\hline & Clarity & Clear & Clear & Clear & Clear & & \\
\hline
\end{tabular}




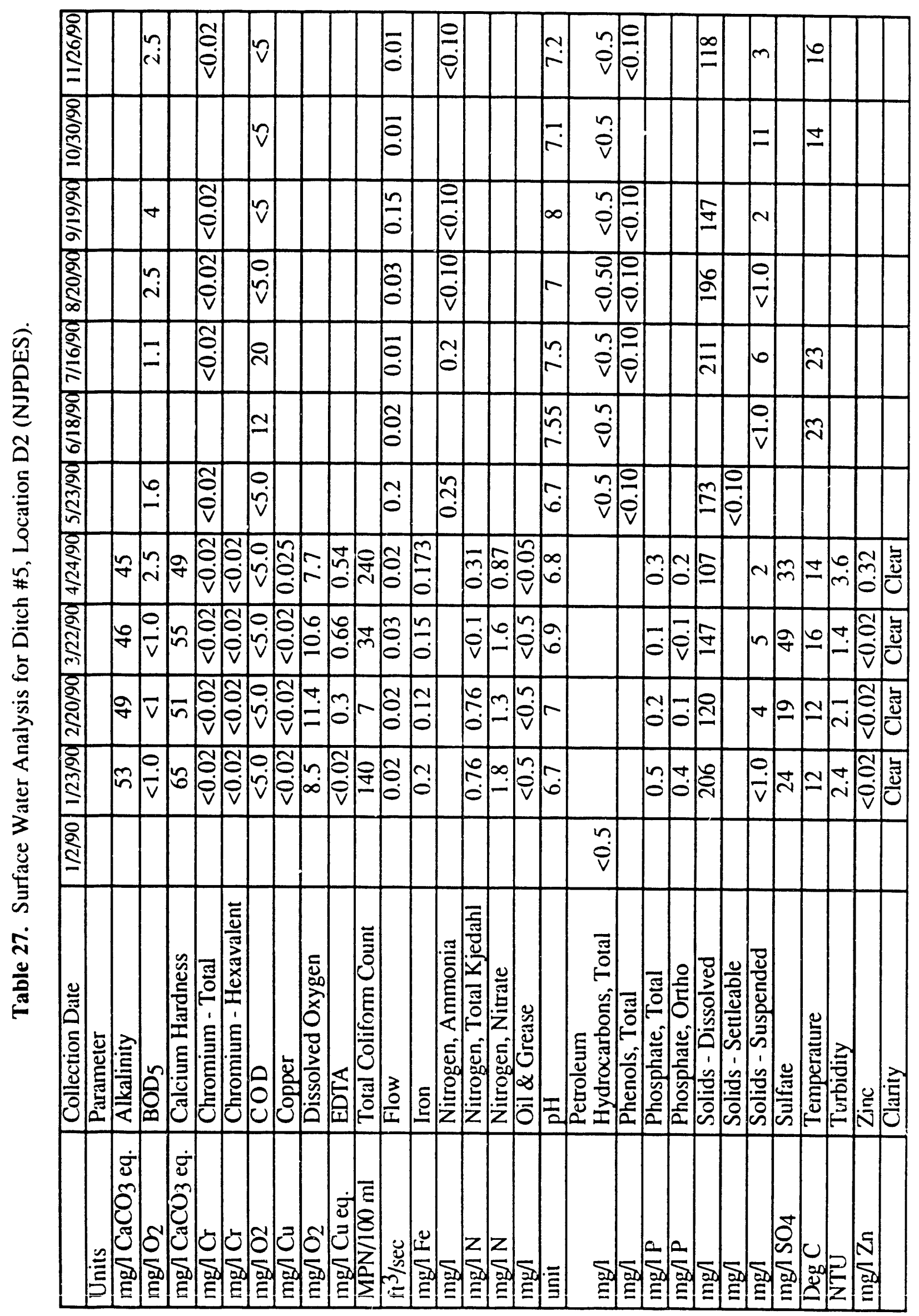


Table 28. Surface Water Analysis for Ditch \#5, Location D2 (NJPDES).

\begin{tabular}{|c|c|c|c|c|c|}
\hline & Collection Date & $10 / 26 / 90$ & $11 / 19 / 90$ & $12 / 14 / 90$ & $\begin{array}{l}\text { Detection } \\
\text { Limit }\end{array}$ \\
\hline Units & \begin{tabular}{|l} 
Parameter \\
\end{tabular} & & & & \\
\hline $\mathrm{mg} / 1$ & $\mathrm{BOD}_{5}$ & ND & ND & 7.86 & 4 \\
\hline $\mathrm{mg} / \mathrm{l}$ & $\begin{array}{l}\text { Chromium, } \\
\text { Total }\end{array}$ & ND & ND & ND & 0.01 \\
\hline $\mathrm{mg} / 1$ & $\infty$ & ND & ND & ND & 50 \\
\hline $\mathrm{gpm}^{*}$ & Flow & 10 & 30 & & NA \\
\hline $\mathrm{mg} / 1$ & Method Blank & ND & ND & & 0.01 \\
\hline $\mathrm{mg} / \mathrm{l}$ & $\begin{array}{l}\text { Nitrogen, } \\
\text { Ammonia }\end{array}$ & ND & ND & ND & 0.5 \\
\hline $\mathrm{mg} / 1$ & $\mathrm{pH}$ & 7.23 & 7 & 7.86 & NA \\
\hline $\mathrm{mg} / \mathrm{l}$ & $\begin{array}{l}\text { Petroleum } \\
\text { Hydrocarbons } \\
\text { by IR }\end{array}$ & ND & ND & ND & 1 \\
\hline $\mathrm{mg} / 1$ & Phenols, Total & ND & ND & ND & 0.2 \\
\hline $\mathrm{mg} / \mathrm{l}$ & $\begin{array}{l}\text { Solids - } \\
\text { Dissolved, } \\
\text { Total }\end{array}$ & 110 & 91 & 130 & 5 \\
\hline $\mathrm{mg} / \mathrm{l}$ & $\begin{array}{l}\text { Solids - } \\
\text { Suspended, } \\
\text { Total }\end{array}$ & 8.3 & 5.1 & 12 & 5 \\
\hline
\end{tabular}

$\mathrm{ND}=$ Not Detected; $\mathrm{NA}=$ Not Applicable

*Analysis performed on-site at time of sampling. 
Table 29. Water Analysis for Water Supply, Location E1.

\begin{tabular}{|c|c|c|c|c|c|c|c|}
\hline & Collection Date & $1 / 23 / 90$ & $2 / 20 / 90$ & $3 / 22 / 90$ & $4 / 24 / 90$ & $5 / 23 / 90$ & $8 / 20 / 90$ \\
\hline Units & \begin{tabular}{|l} 
Parameter \\
\end{tabular} & & & & & & \\
\hline $\mathrm{mg} / \mathrm{CaCO} \mathrm{Ca}_{3}$ eq. & Alkalinity & 36 & 36 & 40 & 44 & & \\
\hline $\mathrm{mg} / / \mathrm{O}_{2}$ & $\mathrm{BOD}_{5}$ & & & & & 1.2 & 1.5 \\
\hline $\mathrm{mg} / \mathrm{l} \mathrm{O}_{2}$ & $\infty$ & & & & & $<5.0$ & $<5.0$ \\
\hline $\mathrm{mg} / \mathrm{CaCO} \mathrm{Ca}_{3}$. & $\begin{array}{l}\text { Calcium } \\
\text { Hardness }\end{array}$ & 67 & 58 & 60 & 66 & & \\
\hline $\mathrm{mg} / \mathrm{Cu}$ & Copper & $<0.02$ & $<0.02$ & $<0.02$ & $<0.025$ & & \\
\hline$M P N / 100 \mathrm{ml}$ & $\begin{array}{l}\text { Total Coliform } \\
\text { Count } \\
\end{array}$ & $<2$ & $<2$ & $<2$ & $<2$ & & \\
\hline $\mathrm{mg} / \mathrm{Fe}$ & Iron & 0.08 & 0.02 & 0.1 & 0.055 & & \\
\hline $\mathrm{mg} / \mathrm{l}$ & $\begin{array}{l}\text { Nitrogen, } \\
\text { Ammonia }\end{array}$ & & & & & 0.1 & $<0.10$ \\
\hline $\mathrm{mg} / \mathrm{N}$ & $\begin{array}{l}\text { Nitrogen, Total } \\
\text { Kjedahl }\end{array}$ & 1.2 & 1 & 0.42 & 0.2 & & \\
\hline $\mathrm{mg} / \mathrm{l} \mathrm{N}$ & \begin{tabular}{|l} 
Nitrogen, \\
Nitrate \\
\end{tabular} & 1.8 & 1.8 & 2.9 & 0.85 & & \\
\hline unit & $\mathrm{pH}$ & 6.7 & 7.2 & 7 & 7 & 6.6 & 7 \\
\hline $\mathrm{mg} / \mathrm{l}$ & $\begin{array}{l}\text { Petroleum } \\
\text { Hydrocarbons, } \\
\text { Total }\end{array}$ & & & & & $<0.50$ & $<0.50$ \\
\hline $\mathrm{mg} / 1$ & \begin{tabular}{|l|} 
Phenols, Total \\
\end{tabular} & & & & & $<0.10$ & $<1.10$ \\
\hline $\mathrm{mg} / \mathrm{P}$ & $\begin{array}{l}\text { Phosphate, } \\
\text { Total }\end{array}$ & $<0.1$ & $<0.1$ & $<0.1$ & 0.1 & & \\
\hline $\mathrm{mg} / \mathrm{P}$ & $\begin{array}{l}\text { Phosphate, } \\
\text { Ortho }\end{array}$ & $<0.1$ & $<0.1$ & $<0.1$ & 0.1 & & \\
\hline $\mathrm{mg} / \mathrm{l}$ & \begin{tabular}{|l|} 
Solids - \\
Dissolved \\
\end{tabular} & 278 & 136 & 155 & 162 & 182 & 259 \\
\hline $\mathrm{mg} / \mathrm{I}$ & $\begin{array}{l}\text { Solids - } \\
\text { Suspended } \\
\end{array}$ & & & & & & $<1.0$ \\
\hline $\mathrm{mg} / \mathrm{Mn}$ & \begin{tabular}{|l} 
Manganese \\
\end{tabular} & $<0.01$ & $<0.01$ & $<0.01$ & $<0.010$ & & \\
\hline $\mathrm{mg} / \mathrm{l} \mathrm{Cl}$ & Chloride & 74 & 29 & 27 & 25 & & \\
\hline $\mathrm{mg} / \mathrm{l}$ & $\begin{array}{l}\text { Solids - } \\
\text { Setteable }\end{array}$ & & & & & $<0.10$ & \\
\hline $\mathrm{mg} / 1 \mathrm{SO}_{4}$ & Sulfate & 40 & 37 & 29 & 38 & & \\
\hline DegC & Temperature & 5 & 8 & 10 & 12 & & \\
\hline NTU & Turbidity & 0.27 & 0.35 & 0.24 & 1.2 & & \\
\hline
\end{tabular}


Table 30. Surface Water Analysis for the Millstone River, Location M1.

\begin{tabular}{|c|c|c|c|c|c|c|c|}
\hline & Collection Date & $1 / 23 / 90$ & $2 / 20 / 90$ & $3 / 22 / 90$ & $4 / 24 / 90$ & $5 / 23 / 90$ & $8 / 20 / 90$ \\
\hline Units & Parameter & & & & & & \\
\hline $\mathrm{mg} / \mathrm{CaCO} \mathrm{Ca}_{3}$. & Alkalinity & 14 & 29 & 11 & 16 & & \\
\hline $\mathrm{mg} / \mathrm{l} \mathrm{O}$ & $\mathrm{BOD}_{5}$ & & & & & 2.3 & 3.3 \\
\hline $\mathrm{mg} / \mathrm{l} \mathrm{O}$ & $\infty$ & & & & & 26 & 30 \\
\hline $\mathrm{mg} / \mathrm{l} \mathrm{CaCO}_{3} \mathrm{eq}$. & $\begin{array}{l}\text { Calcium } \\
\text { Hardness }\end{array}$ & 22 & 39 & 24 & 26 & & \\
\hline $\mathrm{mg} / \mathrm{l} \mathrm{Cr}$ & $\begin{array}{l}\text { Chromium - } \\
\text { Total }\end{array}$ & $<0.02$ & $<0.02$ & $<0.02$ & $<0.02$ & & \\
\hline $\mathrm{mg} / \mathrm{l} \mathrm{Cr}$ & $\begin{array}{l}\text { Chromium - } \\
\text { Hexavalent }\end{array}$ & $<0.02$ & $<0.02$ & $<0.02$ & $<0.02$ & & \\
\hline $\mathrm{mg} / \mathrm{l} \mathrm{Cu}$ & Copper & $<0.02$ & $<0.02$ & $<0.02$ & $<0.025$ & & \\
\hline $\mathrm{mg} / \mathrm{l} \mathrm{Cu}$ eq. & EDTA & $<0.02$ & 0.24 & 0.38 & 0.24 & & \\
\hline $\mathrm{mg} / \mathrm{l} \mathrm{Fe}$ & Iron & 0.66 & 0.12 & 0.58 & 0.75 & & \\
\hline $\mathrm{mg} / \mathrm{l}$ & $\begin{array}{l}\text { Nitrogen, } \\
\text { Ammonia }\end{array}$ & & & & & 1 & 0.36 \\
\hline $\mathrm{mg} / 1 \mathrm{~N}$ & $\begin{array}{l}\text { Nitrogen, } \\
\text { Nitrate } \\
\end{array}$ & 2.6 & 1.9 & 2.9 & 2.2 & & \\
\hline $\mathrm{mg} / \mathrm{l}$ & Oil \& Grease & $<0.5$ & 0.6 & $<0.5$ & $<0.5$ & & \\
\hline unit & $\mathrm{pH}$ & 6.5 & 7.1 & 6.8 & 6.6 & 6.5 & 6.6 \\
\hline $\mathrm{mg} / 1$ & $\begin{array}{l}\text { Petroleum } \\
\text { Hydrocarbons, } \\
\text { Total }\end{array}$ & & & & & $<0.50$ & $<0.50$ \\
\hline $\mathrm{mg} / \mathrm{l}$ & Phenols, Total & & & & & 0.2 & $<0.10$ \\
\hline $\mathrm{mg} / \mathrm{l} P$ & $\begin{array}{l}\text { Phosphate, } \\
\text { Total }\end{array}$ & 0.1 & $<0.1$ & 0.1 & $<0.10$ & & \\
\hline $\mathrm{mg} / \mathrm{P}$ & $\begin{array}{l}\text { Phosphate, } \\
\text { Ortho }\end{array}$ & $<0.1$ & $<0.1$ & $<0.1$ & $<0.10$ & & \\
\hline $\mathrm{mg} / 1$ & $\begin{array}{l}\text { Solids - } \\
\text { Dissolved }\end{array}$ & $\begin{array}{c}1 \\
38 \\
\end{array}$ & 101 & 89 & 116 & 140 & 114 \\
\hline $\mathrm{mg} / 1$ & $\begin{array}{l}\text { Solids - } \\
\text { Settleable }\end{array}$ & & & & & $<0.10$ & \\
\hline $\mathrm{mg} / \mathrm{l}$ & $\begin{array}{l}\text { Solids - } \\
\text { Suspended }\end{array}$ & 7 & 7 & 18 & 14 & & 22 \\
\hline $\mathrm{mg} / \mathrm{l} \mathrm{SO} 4$ & Sulfate & 23 & 17 & 19 & 20 & & \\
\hline NTU & Turbidity & 6.3 & 3.3 & 8.4 & 10 & & \\
\hline \multirow[t]{2}{*}{$\mathrm{mg} / \mathrm{I} \mathrm{Zn}$} & Zinc & $<0.02$ & $<0.02$ & $<0.02$ & 0.023 & & \\
\hline & Clarity & Clear & Clear & $\begin{array}{c}\text { Slightly } \\
\text { Cloudy }\end{array}$ & Clear & & \\
\hline
\end{tabular}


Table 31. Surface Water Analysis for Plainsboro, Location P1.

\begin{tabular}{|c|c|c|c|c|c|c|c|}
\hline & $\begin{array}{l}\text { Collection Date } \\
\ldots . . . . . .> \\
\end{array}$ & $1 / 23 / 90$ & $2 / 20 / 90$ & $3 / 22 / 90$ & $4 / 24 / 90$ & $5 / 23 / 90$ & $8 / 20 / 90$ \\
\hline Units & Parameter & & & & & & \\
\hline $\mathrm{mg} / \mathrm{CaCO}_{3}$ eq. & Alkalinity & 9.6 & 8.6 & 8.6 & 8.6 & & \\
\hline $\mathrm{mg} / \mathrm{l} \mathrm{O}_{2}$ & $\mathrm{BOD}_{5}$ & & & & & 2.8 & 3.7 \\
\hline $\mathrm{mg} / \mathrm{lO}$ & $\infty$ & & & & & $<5.0$ & 20 \\
\hline $\mathrm{mg} / 1 \mathrm{CaCO}_{3} \mathrm{eg}$. & $\begin{array}{l}\text { Calcium } \\
\text { Hardness }\end{array}$ & 22 & 22 & 22 & 21 & & \\
\hline $\mathrm{mg} / \mathrm{ll} \mathrm{Cr}$ & $\begin{array}{l}\text { Chromium } \\
\text { Total }\end{array}$ & $<0.02$ & $<0.02$ & $<0.02$ & $<0.02$ & & \\
\hline $\mathrm{mg} / \mathrm{l} \mathrm{Cr}$ & $\begin{array}{l}\text { Chromium } \\
\text { Hexavalent }\end{array}$ & $<0.02$ & $<0.02$ & $<0.02$ & $<0.02$ & & \\
\hline $\mathrm{mg} / \mathrm{Cu}$ & Copper & $\leq 0.02$ & $\leq 0.02$ & $\leq 0.02$ & $<0.025$ & & \\
\hline $\mathrm{mg} / \mathrm{l} \mathrm{Cu}$ eq. & EDTA & $<0.02$ & 0.02 & 0.44 & 0.18 & & \\
\hline $\mathrm{mg} / \mathrm{Fe}$ & Iron & 0.62 & 0.63 & 1 & 1.7 & & \\
\hline $\mathrm{mg} / 1$ & $\begin{array}{l}\text { Nitrogen, } \\
\text { Ammonia }\end{array}$ & & & & & 0.95 & $<0.10$ \\
\hline $\mathrm{mg} / \mathrm{N}$ & $\begin{array}{l}\text { Nitrogen, } \\
\text { Nitrate }\end{array}$ & 2.5 & 2.5 & 2.4 & 1.3 & & \\
\hline $\mathrm{mg} / \mathrm{l}$ & Oil \& Grease & $<0.5$ & 0.5 & $<0.5$ & $<0.5$ & & \\
\hline unit & $\mathrm{pH}$ & 6.2 & 7 & 6.5 & 6.6 & 6.3 & 6.4 \\
\hline $\mathrm{mg} / \mathrm{l}$ & $\begin{array}{l}\text { Petroleum } \\
\text { Hydrocarbons, } \\
\text { Total } \\
\end{array}$ & & & & & $<0.50$ & $<0.50$ \\
\hline $\mathrm{mg} / \mathrm{l}$ & Phenols, Total & & & & & 0.1 & $<0.1$ \\
\hline $\mathrm{mg} / \mathrm{P}$ & $\begin{array}{l}\text { Phosphate, } \\
\text { Total } \\
\end{array}$ & $<0.1$ & $<0.1$ & 0.1 & 0.2 & & \\
\hline $\mathrm{mg} / \mathrm{l} P$ & $\begin{array}{l}\text { Phosphate, } \\
\text { Ortho }\end{array}$ & $<0.1$ & $<0.1$ & $<0.1$ & $<0.1$ & & \\
\hline $\mathrm{mg} / \mathrm{l}$ & $\begin{array}{l}\text { Solids- } \\
\text { Dissolved } \\
\end{array}$ & 184 & 91 & 110 & 109 & 111 & 99 \\
\hline $\mathrm{mg} / \mathrm{l}$ & $\begin{array}{l}\text { Solids - } \\
\text { Settleable }\end{array}$ & & & & & $<0.10$ & \\
\hline $\mathrm{mg} / \mathrm{l}$ & $\begin{array}{l}\text { Solids - } \\
\text { Suspended }\end{array}$ & 8 & 13 & 26 & 30 & & 35 \\
\hline $\mathrm{mg} / \mathrm{l} \mathrm{SO} 4$ & Sulfate & 26 & 23 & 19 & 20 & & \\
\hline NTU & Turbidity & 7.5 & 8.4 & 16 & 20 & & \\
\hline $\mathrm{mg} / \mathrm{l} \mathrm{Zn}$ & Zinc & $<0.02$ & $<0.02$ & $<0.02$ & $<0.020$ & & \\
\hline & Clarity & $\begin{array}{l}\text { Slightly } \\
\text { Cloudy }\end{array}$ & $\begin{array}{l}\text { Slightly } \\
\text { Cloudy }\end{array}$ & $\begin{array}{l}\text { Slightly } \\
\text { Cloudy }\end{array}$ & Cloudy & & \\
\hline
\end{tabular}


Table 32. Surface Water Analysis for Plainsboro, Location P2.

\begin{tabular}{|c|c|c|c|c|c|c|c|}
\hline & Collection Date & $1 / 23 / 90$ & $2 / 20 / 90$ & $3 / 22 / 90$ & $4 / 24 / 90$ & $5 / 23 / 90$ & $8 / 20 / 90$ \\
\hline Units & Parameter & & & & & & \\
\hline $\mathrm{mg} / \mathrm{l} \mathrm{CaCO}$ eq. & Alkalinity & 10.2 & 11.4 & 7.4 & 13 & & \\
\hline $\mathrm{mg} / \mathrm{l} \mathrm{O2}$ & BOD5 & & & & & $<1.0$ & 9.4 \\
\hline $\mathrm{mg} / \mathrm{l} \mathrm{O} 2$ & $\infty$ & & & & & $<5.0$ & 23 \\
\hline $\mathrm{mg} / 1 \mathrm{CaCO}_{3} \mathrm{eq}$. & $\begin{array}{l}\text { Calcium } \\
\text { Hardness }\end{array}$ & 12 & 15 & 11 & 14 & & \\
\hline $\mathrm{mg} / \mathrm{l} \mathrm{Cr}$ & $\begin{array}{l}\text { Chromium - } \\
\text { Total }\end{array}$ & $<0.02$ & $<0.02$ & $<0.02$ & $<0.020$ & & \\
\hline $\mathrm{mg} / \mathrm{l} \mathrm{Cr}$ & $\begin{array}{l}\text { Chromium - } \\
\text { Hexavalent }\end{array}$ & $<0.02$ & $<0.02$ & $<0.02$ & $<0.02$ & & \\
\hline $\mathrm{mg} / \mathrm{l} \mathrm{Cu}$ & Copper & $<0.02$ & $<0.02$ & $<0.02$ & $<0.025$ & & \\
\hline $\mathrm{mg} / \mathrm{l} \mathrm{Cu}$ eq. & EDTA & $<0.02$ & $<0.02$ & 0.22 & 0.2 & & \\
\hline $\mathrm{mg} / \mathrm{f} \mathrm{Fe}$ & Iron & 0.42 & 0.34 & 0.39 & 0.6 & & \\
\hline $\mathrm{mg} / \mathrm{l}$ & $\begin{array}{l}\text { Nitrogen, } \\
\text { Ammonia }\end{array}$ & & & & & 0.11 & $<0.10$ \\
\hline & $\begin{array}{l}\text { Nitrogen, } \\
\text { Nitrate }\end{array}$ & 2 & 3 & 1.9 & 2.5 & & \\
\hline $\mathrm{mg} / 1$ & Oil \& Grease & $<0.5$ & 0.9 & $<0.5$ & $<0.5$ & & \\
\hline unit & $\mathrm{pH}$ & 6.2 & 6.8 & 6.9 & 6.6 & 6.3 & 6.5 \\
\hline $\mathrm{mg} / \mathrm{l}$ & $\begin{array}{l}\text { Petroleum } \\
\text { Hydrocarbons, } \\
\text { Total }\end{array}$ & & & & & $<0.5$ & $<0.50$ \\
\hline $\mathrm{mg} / 1$ & Phenols, Total & & & & & 0.1 & $<0.10$ \\
\hline $\mathrm{mg} / \mathrm{P}$ & $\begin{array}{l}\text { Phosphate, } \\
\text { Total }\end{array}$ & $<0.1$ & $<0.1$ & $<0.1$ & $<0.1$ & & \\
\hline $\mathrm{mg} / \mathrm{P}$ & $\begin{array}{l}\text { Phosphate, } \\
\text { Ortho }\end{array}$ & $<0.1$ & $<0.1$ & $<0.1$ & $<0.1$ & & \\
\hline $\mathrm{mg} / 1$ & $\begin{array}{l}\text { Solids - } \\
\text { Dissolved }\end{array}$ & 67 & 62 & 53 & 84 & 102 & 88 \\
\hline $\mathrm{mg} / 1$ & $\begin{array}{l}\text { Solids - } \\
\text { Settleable } \\
\end{array}$ & & & & & $<0.10$ & \\
\hline $\mathrm{mg} / 1$ & $\begin{array}{l}\text { Solids - } \\
\text { Suspended }\end{array}$ & 3 & 8 & 9 & $<1.0$ & & 3 \\
\hline $\mathrm{mg} / \mathrm{l} \mathrm{SO} 4$ & Sulfate & 13 & 8.6 & 9.3 & 8.4 & & \\
\hline NTU & Turbidity & 2.6 & 3.5 & 0.34 & 3.1 & & \\
\hline \multirow[t]{2}{*}{$\mathrm{mg} / \mathrm{I} \mathrm{Zn}$} & Zinc & $<0.02$ & $<0.02$ & $<0.02$ & $<0.020$ & & \\
\hline & Clarity & Clear & $\begin{array}{l}\text { Slightly } \\
\text { Cloudy }\end{array}$ & Clear & Clear & & \\
\hline
\end{tabular}


Table 33. Detention Basin Influent Analysis (NJPDES)

\begin{tabular}{|c|c|c|c|c|c|}
\hline & Collection Date & $\begin{array}{l}\text { Inflow } 1 \\
5 / 18 / 90 \\
\end{array}$ & $\begin{array}{l}\text { Inflow } 2 \\
5 / 18 / 90\end{array}$ & $\begin{array}{l}\text { Inflow } 1 \\
8 / 13 / 90 \\
\end{array}$ & $\begin{array}{l}\text { Inflow } 2 \\
8 / 13 / 90 \\
\end{array}$ \\
\hline Units & Parameter & & & & \\
\hline $\mathrm{mg} / \mathrm{l} \mathrm{O}$ & $\mathrm{BOD}_{5}$ & 1 & 9 & 1.2 & 2 \\
\hline $\mathrm{mg} / \mathrm{l} \mathrm{O}$ & COD & 4 & 11 & 23 & $<5.0$ \\
\hline $\mathrm{mg} / \mathrm{l}$ & Cadmium & 0.02 & & & \\
\hline $\mathrm{mg} / \mathrm{l}$ & $\begin{array}{l}\text { Chromium - } \\
\text { Hexavalent }\end{array}$ & 0.02 & 0.02 & & \\
\hline $\mathrm{mg} / \mathrm{l}$ & $\begin{array}{l}\text { Chromium - } \\
\text { Total }\end{array}$ & & 0.02 & $<0.02$ & $<0.02$ \\
\hline $\mathrm{mg} / 1$ & $\begin{array}{l}\text { Nitrogen, } \\
\text { Ammonia }\end{array}$ & $<0.01$ & $<0.10$ & $<0.10$ & $<0.10$ \\
\hline $\mathrm{mg} / \mathrm{l}$ & $\begin{array}{l}\text { Petroleum } \\
\text { Hydrocarbons, } \\
\text { Total }\end{array}$ & 0.5 & 0.5 & & \\
\hline unit & $\overline{\mathrm{pH}}$ & & & $\overline{7}$ & 7.4 \\
\hline $\mathrm{mg} / \mathrm{l}$ & Phenols, Total & & 0.1 & 0.2 & $<0.10$ \\
\hline $\mathrm{mg} / \mathrm{l}$ & $\begin{array}{l}\text { Solids - } \\
\text { Dissolved }\end{array}$ & 224 & 151 & 96 & 191 \\
\hline $\mathrm{mg} / \mathrm{l}$ & $\begin{array}{l}\text { Solids - } \\
\text { Setteable }\end{array}$ & 0.1 & 0.1 & $<0.10$ & 0.1 \\
\hline $\mathrm{mg} / \mathrm{/SO}$ & Sulfate & 23 & 32 & & \\
\hline
\end{tabular}


Table 34. Groundwater Analysis for Well D-11

\begin{tabular}{|c|c|c|c|c|c|c|c|}
\hline & Collection Date & $2 / 12 / 90$ & $5 / 18 / 90$ & $5 / 18 / 90$ & $8 / 13 / 90$ & $11 / 21 / 90$ & $\begin{array}{l}\text { Detection } \\
\text { Limit"* }\end{array}$ \\
\hline Units & Parameter & & (Before) & (After) & & & \\
\hline $\mathrm{mg} / \mathrm{l}$ & $\begin{array}{l}\text { Barium, } \\
\text { Dissolved }\end{array}$ & & 0.12 & 0.22 & & & \\
\hline $\mathrm{mg} / \mathrm{l}$ & Chloride & & & & 17 & 29 & 3 \\
\hline $\mathrm{mg} / \mathrm{l}$ & $\begin{array}{l}\text { Lead, } \\
\text { Dissolved }\end{array}$ & & 0.05 & 0.05 & $<0.05$ & ND & \\
\hline $\mathrm{mg} / \mathrm{l}$ & \begin{tabular}{|l} 
Nitrogen, \\
Ammonia \\
\end{tabular} & & 0.1 & & $<0.10$ & ND & 0.5 \\
\hline $\mathrm{mg} / \mathrm{l}$ & \begin{tabular}{|l|} 
Nitrogen, \\
Nitrate \\
\end{tabular} & & & & 1.2 & ND & 1 \\
\hline $\mathrm{mg} / \mathrm{l}$ & $\begin{array}{l}\text { Organic } \\
\text { Carbon, Total }\end{array}$ & & & & 3 & & \\
\hline $\mathrm{mg} / \mathrm{l}$ & $\begin{array}{l}\text { Organic, } \\
\text { Halides, Total }\end{array}$ & & & & $<30$ & & \\
\hline $\mathrm{mg} / \mathrm{l}$ & $\begin{array}{l}\text { Petroleum } \\
\text { Hydrocarbons, } \\
\text { Total }\end{array}$ & & & & $<0.50$ & & \\
\hline unit & $\mathrm{pH}$ & 6 & 6.5 & & & $5.2^{\circ}$ & $\overline{N A}$ \\
\hline $\mathrm{mg} / \mathrm{l}$ & $\begin{array}{l}\text { Phenols, } \\
\text { Distillation }\end{array}$ & & & & $<0.10$ & ND & 0.2 \\
\hline $\mathrm{mg} / 1$ & $\begin{array}{l}\text { Solids - } \\
\text { Dissolved. } \\
\text { Total } \\
\end{array}$ & 126 & 47 & 133 & 110 & 250 & 5 \\
\hline$\mu \mathrm{mho} / \mathrm{cm}$ & $\begin{array}{l}\text { Specific } \\
\text { Conductance } \\
925 \mathrm{C} \\
\end{array}$ & 170 & 184 & & & 140 & NA \\
\hline $\mathrm{mg} / \mathrm{l} \mathrm{SO}$ & \begin{tabular}{|l} 
Sulfate, \\
Dissolved \\
\end{tabular} & 24 & 30 & 21 & 30 & 20 & 5 \\
\hline Deg. C & Temperature & & 13.6 & & & $16^{*}$ & $\overline{N A}$ \\
\hline $\mathrm{mg} / \mathrm{I}$ & Titanium & & 0.05 & 0.05 & & & \\
\hline
\end{tabular}

$\mathrm{ND}=$ Not Detected; NA=Not Applicable

*: Analysis performed on-site at time of sampling.

** For $11 / 21 / 90$ only 
Table 35. Groundwater Analysis for Well D-12

\begin{tabular}{|c|c|c|c|c|c|c|c|}
\hline & Collection Date & $2 / 12 / 90$ & $5 / 18 / 90$ & $5 / 18 / 90$ & $8 / 13 / 90$ & $11 / 21 / 9$ & $\begin{array}{l}\text { Detection } \\
\text { Limit } \cdots\end{array}$ \\
\hline Units & Parameter & & (Before) & (After) & & & \\
\hline $\mathrm{mg} / \mathrm{l}$ & $\begin{array}{l}\text { Barium, } \\
\text { Dissolved }\end{array}$ & & 0.08 & 0.07 & & & \\
\hline $\mathrm{mg} / \mathrm{l}$ & Chloride & & & & 19 & 18 & 3 \\
\hline $\mathrm{mg} / \mathrm{l}$ & $\begin{array}{l}\text { Chromium - } \\
\text { Hexavalent }\end{array}$ & & & & $<0.02$ & & \\
\hline $\mathrm{mg} / \mathrm{I}$ & $\begin{array}{l}\text { Lead, } \\
\text { Dissolved }\end{array}$ & & 0.05 & 0.05 & $<0.05$ & ND & \\
\hline & $\begin{array}{l}\text { Nitrogen, } \\
\text { Ammonia }\end{array}$ & & 0.1 & & $<0.10$ & ND & 0.5 \\
\hline $\mathrm{mg} / 1$ & $\begin{array}{l}\text { Nitrogen, } \\
\text { Nitrate }\end{array}$ & & & & 0.21 & ND & 1 \\
\hline $\mathrm{mg} / 1$ & $\begin{array}{l}\text { Organic } \\
\text { Carbon, Total }\end{array}$ & & & & 3 & & \\
\hline $\mathrm{mg} / 1$ & $\begin{array}{l}\text { Organic } \\
\text { Halides, Total }\end{array}$ & & & & 48 & & \\
\hline $\mathrm{mg} / \mathrm{I}$ & $\begin{array}{l}\text { Petroleum } \\
\text { Hydrocarbons, } \\
\text { Total } \\
\end{array}$ & & & & $<0.50$ & & \\
\hline unit & $\mathrm{pH}$ & 5.2 & 5.6 & & & $5.2^{\prime}$ & $\overline{N A}$ \\
\hline $\mathrm{mg} / \mathrm{l}$ & $\begin{array}{l}\text { Phenols, } \\
\text { Distillation } \\
\end{array}$ & & & & $<0.10$ & ND & 0.2 \\
\hline $\mathrm{mg} / \mathrm{l}$ & $\begin{array}{l}\text { Solids - } \\
\text { Dissolved, } \\
\text { Total } \\
\end{array}$ & 142 & 160 & 176 & 116 & 92 & 5 \\
\hline$\mu \mathrm{mho} / \mathrm{cm}$ & $\begin{array}{l}\text { Specific } \\
\text { Conductance @ } \\
25 \mathrm{C} \\
\end{array}$ & 181 & 192 & & & 180 & NA \\
\hline $\mathrm{mg} / \mathrm{fSO}_{4}$ & $\begin{array}{l}\text { Sulfate, } \\
\text { Dissolved }\end{array}$ & 30 & 37 & 40 & 39 & 25 & 5 \\
\hline Deg. C & Temperature & & 13 & & & $16^{\circ}$ & $\mathrm{NA}$ \\
\hline $\mathrm{mg} / \mathrm{l}$ & Titanium & & 0.05 & 0.05 & & & \\
\hline
\end{tabular}

ND=Not Detected; NA=Not Applicable

*: Analysis performed on-site at time of sampling.

** For $11 / 21 / 90$ only 
Table 36. Groundwater Analysis for Well MW-14

\begin{tabular}{|c|c|c|c|c|c|c|}
\hline & \begin{tabular}{|l} 
Collection Date \\
$\ldots . . . . . .>$
\end{tabular} & $2 / 12 / 90$ & $5 / 18 / 90$ & $8 / 13 / 90$ & $11 / 21 / 90$ & $\begin{array}{l}\text { Detection } \\
\text { Limit. }\end{array}$ \\
\hline Units & Parameter & & & & & \\
\hline $\mathrm{mg} / \mathrm{l}$ & Chloride & & & 7 & 6 & 3 \\
\hline $\mathrm{mg} / \mathrm{l}$ & $\begin{array}{l}\text { Chromium, } \\
\text { Hex. }\end{array}$ & & & $<0.02$ & $\overline{N D}$ & \\
\hline $\mathrm{mg} / \mathrm{l}$ & $\begin{array}{l}\text { Lead, } \\
\text { Dissolved }\end{array}$ & & & $<0.05$ & ND & \\
\hline $\mathrm{mg} / \mathrm{l}$ & $\begin{array}{l}\text { Nitrogen, } \\
\text { Ammonia }\end{array}$ & & 0.1 & $<0.10$ & ND & 0.5 \\
\hline $\mathrm{mg} / \mathrm{l}$ & $\begin{array}{l}\text { Nitrogen, } \\
\text { Nitrate }\end{array}$ & & & 2.9 & 2 & 1 \\
\hline $\mathrm{mg} / 1$ & $\begin{array}{l}\text { Organic } \\
\text { Carbon, Total }\end{array}$ & & & 3 & & \\
\hline $\mathrm{mg} / \mathrm{l}$ & $\begin{array}{l}\text { Organic } \\
\text { Halides, Total }\end{array}$ & & & 31 & & \\
\hline $\mathrm{mg} / \mathrm{l}$ & $\begin{array}{l}\text { Petroleum } \\
\text { Hydrocarbons, } \\
\text { Total }\end{array}$ & & & $<0.50$ & & \\
\hline unit & $\mathrm{pH}$ & 6 & 5.8 & & $5.5^{\circ}$ & NA \\
\hline $\mathrm{mg} / \mathrm{l}$ & $\begin{array}{l}\text { Phenols, } \\
\text { Distillation }\end{array}$ & & & $<0.10$ & ND & 0.2 \\
\hline $\mathrm{mg} / \mathrm{l}$ & $\begin{array}{l}\text { Solids - } \\
\text { Dissolved, } \\
\text { Total }\end{array}$ & 61 & 76 & 70 & 54 & 5 \\
\hline$\mu \mathrm{mho} / \mathrm{cm}$ & $\begin{array}{l}\text { Specific } \\
\text { Conductance @ } \\
25 \mathrm{C}\end{array}$ & 84 & 110 & & 85 & NA \\
\hline $\mathrm{mg} / \mathrm{l} \mathrm{SO} 4$ & $\begin{array}{l}\text { Sulfate, } \\
\text { Dissolved }\end{array}$ & 2.1 & 14 & 15 & 10 & 5 \\
\hline Deg. C & Temperature & & & & $14^{\circ}$ & $N A$ \\
\hline
\end{tabular}

$\mathrm{ND}=$ Not Detected; $\mathrm{NA}=$ Not Applicable

*: Analysis performed on-site at time of sampling.

** For $11 / 21 / 90$ only 
Table 37. Groundwater Analysis for Well MW-15

\begin{tabular}{|c|c|c|c|c|c|c|}
\hline & \begin{tabular}{|l|} 
Collection Date \\
$\ldots . . . .$. \\
\end{tabular} & $2 / 12 / 90$ & $5 / 18 / 90$ & $8 / 13 / 90$ & $11 / 21 / 90$ & $\begin{array}{l}\text { Detection } \\
\text { Limit * }\end{array}$ \\
\hline Units & Parameter & & & & & \\
\hline $\mathrm{mg} / \mathrm{l}$ & \begin{tabular}{|l} 
Chloride \\
\end{tabular} & & & 4.5 & 6 & 3 \\
\hline $\mathrm{mg} / \mathrm{l}$ & $\begin{array}{l}\text { Chromium, } \\
\text { Hex. }\end{array}$ & & & $<0.02$ & ND & \\
\hline $\mathrm{mg} / \mathrm{I}$ & $\begin{array}{l}\text { Lead, } \\
\text { Dissolved }\end{array}$ & & & $<0.05$ & ND & \\
\hline $\mathrm{mg} / \mathrm{I}$ & \begin{tabular}{|l} 
Nitrogen, \\
Ammonia \\
\end{tabular} & & 0.1 & $<0.10$ & ND & 0.5 \\
\hline $\mathrm{mg} / \mathrm{l}$ & \begin{tabular}{|l} 
Nitrogen, \\
Nitrate \\
\end{tabular} & & & 0.94 & ND & 1 \\
\hline $\mathrm{mg} / \mathrm{l}$ & $\begin{array}{l}\text { Organic } \\
\text { Carbon, Total } \\
\end{array}$ & & & 3 & & \\
\hline $\mathrm{mg} / \mathrm{l}$ & $\begin{array}{l}\text { Organic } \\
\text { Halides, Total }\end{array}$ & & & 30 & & \\
\hline $\mathrm{mg} / \mathrm{l}$ & $\begin{array}{l}\text { Petroleum } \\
\text { Hydrocarbons, } \\
\text { Total } \\
\end{array}$ & & & $\begin{array}{c}< \\
0.50\end{array}$ & & \\
\hline unit & $\mathrm{pH}$ & $\overline{6}$ & 6.1 & & $5.7^{\circ}$ & $\overline{N A}$ \\
\hline $\mathrm{mg} / \mathrm{l}$ & $\begin{array}{l}\text { Phenols, } \\
\text { Distillation }\end{array}$ & & & $<0.10$ & $\overline{\mathrm{ND}}$ & 0.2 \\
\hline $\mathrm{mg} / \mathrm{l}$ & $\begin{array}{l}\text { Solids - } \\
\text { Dissolved, } \\
\text { Total }\end{array}$ & 91 & 76 & 82 & 69 & 5 \\
\hline$\mu \mathrm{mho} / \mathrm{cm}$ & $\begin{array}{l}\text { Specific } \\
\text { Conductance @ } \\
25 \mathrm{C} \\
\end{array}$ & 108 & 87 & & 75 & $\overline{N A}$ \\
\hline $\mathrm{mg} / \mathrm{l} \mathrm{SO} 4$ & $\begin{array}{l}\text { Sulfate, } \\
\text { Dissolved } \\
\end{array}$ & 14 & 11 & 18 & 12 & 5 \\
\hline Deg.C & Temperature & & & & $13^{\circ}$ & $\overline{N A}$ \\
\hline
\end{tabular}

$\mathrm{ND}=$ Not Detected; NA=Not Applicable

*: Analysis performed on-site at time of sampling.

** For $11 / 21 / 90$ only 
Table 38. Groundwater Analysis for Well MW-16

\begin{tabular}{|c|c|c|c|c|c|c|}
\hline & $\begin{array}{l}\text { Collection Date } \\
\ldots \ldots \ldots \ldots \\
\end{array}$ & $2 / 12 / 90$ & $5 / 18 / 90$ & $8 / 13 / 90$ & $11 / 21 / 90$ & $\begin{array}{l}\text { Detection } \\
\text { Limit*" }\end{array}$ \\
\hline Units & Parameter & & & & & \\
\hline $\mathrm{mg} / \mathrm{l}$ & Chloride & & & 6.5 & 12 & 3 \\
\hline $\mathrm{mg} / \mathrm{l}$ & $\begin{array}{l}\text { Chromium } \\
\text { Hexavalent }\end{array}$ & & & $<0.02$ & ND & \\
\hline $\mathrm{mg} / \mathrm{l}$ & $\begin{array}{l}\text { Lead, } \\
\text { Dissolved }\end{array}$ & & & $<0.05$ & ND & NA \\
\hline $\mathrm{mg} / \mathrm{l}$ & $\begin{array}{l}\text { Nitrogen, } \\
\text { Ammonia } \\
\end{array}$ & & 0.1 & $<0.10$ & ND & 0.5 \\
\hline $\mathrm{mg} / \mathrm{l}$ & $\begin{array}{l}\text { Nitrogen, } \\
\text { Nitrate }\end{array}$ & & & 1.4 & ND & 1 \\
\hline $\mathrm{mg} / \mathrm{l}$ & $\begin{array}{l}\text { Organic } \\
\text { Carbon, Total }\end{array}$ & & & 6 & & \\
\hline $\mathrm{mg} / \mathrm{l}$ & $\begin{array}{l}\text { Organic } \\
\text { Halides, Total }\end{array}$ & & & 143 & & \\
\hline $\mathrm{mg} / \mathrm{l}$ & $\begin{array}{l}\text { Petroleum } \\
\text { Hydrocarbons, } \\
\text { Total }\end{array}$ & & & $<0.50$ & & \\
\hline unit & $\mathrm{pH}$ & 6.5 & 6.3 & & $6.6^{*}$ & $N A$ \\
\hline $\mathrm{mg} / \mathrm{l}$ & $\begin{array}{l}\text { Phenols, } \\
\text { Distillation } \\
\end{array}$ & & & $<0.10$ & $\mathrm{ND}$ & 0.2 \\
\hline $\mathrm{mg} / \mathrm{l}$ & $\begin{array}{l}\text { Solids- } \\
\text { Dissolved, } \\
\text { Total }\end{array}$ & 166 & 186 & 285 & 21 & 5 \\
\hline$\mu \mathrm{mho} / \mathrm{cm}$ & $\begin{array}{l}\text { Specific } \\
\text { Conductance @ } \\
25 \mathrm{C} \\
\end{array}$ & 263 & 330 & & 430 & NA \\
\hline $\mathrm{mg} / \mathrm{l} \mathrm{SO} 4$ & \begin{tabular}{|l|} 
Sulfate, \\
Dissolved \\
\end{tabular} & 30 & 60 & 52 & 41 & 5 \\
\hline Deg.C & Temperature & & & & $14^{\circ}$ & NA \\
\hline
\end{tabular}

$\mathrm{ND}=$ Not Detected; NA=Not Applicable

*: Analysis performed on-site at time of sampling.

** For $11 / 21 / 90$ only 
Table 39. Groundwater Analysis for Well TW2

\begin{tabular}{|c|c|c|c|c|c|c|}
\hline & \begin{tabular}{|l|} 
Collection Date \\
$\ldots . . . . .$.
\end{tabular} & $2 / 12 / 90$ & $5 / 18 / 90$ & $8 / 13 / 90$ & $11 / 21 / 90$ & $\begin{array}{l}\text { Detection } \\
\text { Limit " } \\
\end{array}$ \\
\hline Units & Parameter & & & & & \\
\hline $\mathrm{mg} / \mathrm{l}$ & Chloride & & & 6.5 & 7 & 3 \\
\hline $\mathrm{mg} / \mathrm{l}$ & $\begin{array}{l}\text { Lead, } \\
\text { Dissolved }\end{array}$ & & & 0.06 & ND & \\
\hline $\mathrm{mg} / \mathrm{l}$ & \begin{tabular}{|l} 
Nitrogen, \\
Ammonia
\end{tabular} & & 0.1 & $<0.10$ & ND & 0.5 \\
\hline $\mathrm{mg} / \mathrm{l}$ & \begin{tabular}{|l} 
Nitrogen, \\
Nitrate \\
\end{tabular} & & & 0.92 & ND & 1 \\
\hline $\mathrm{mg} / \mathrm{l}$ & $\begin{array}{l}\text { Organic } \\
\text { Carbon, Total }\end{array}$ & & & 4 & & \\
\hline $\mathrm{mg} / \mathrm{l}$ & $\begin{array}{l}\text { Organic } \\
\text { Halides, Total } \\
\end{array}$ & & & $<30.0$ & & \\
\hline $\mathrm{mg} / \mathrm{I}$ & \begin{tabular}{|l} 
Petroleum \\
Hydrocarbons, \\
Total \\
\end{tabular} & & & $<0.5$ & & \\
\hline unit & $\mathrm{pH}$ & 6.5 & 6.8 & & $6.8^{\circ}$ & NA \\
\hline $\mathrm{mg} / \mathrm{l}$ & $\begin{array}{l}\text { Phenols, } \\
\text { Distillation }\end{array}$ & & & $<0.10$ & ND & 0.2 \\
\hline $\mathrm{mg} / \mathrm{l}$ & \begin{tabular}{|l|} 
Solids - \\
Dissolved, \\
Total \\
\end{tabular} & 211 & 233 & 191 & 190 & 5 \\
\hline$\mu \mathrm{mho} / \mathrm{cm}$ & \begin{tabular}{|l|} 
Specific \\
Conductance @ \\
$25 \mathrm{C}$ \\
\end{tabular} & 294 & 286 & & 260 & NA \\
\hline $\mathrm{mg} / \mathrm{/} \mathrm{SO} \mathrm{S}_{4}$ & \begin{tabular}{|l|} 
Sulfate, \\
Dissolved \\
\end{tabular} & 38 & 29 & 42 & 12 & 5 \\
\hline Deg.C & Temperature & & & & $12^{\circ}$ & $\overline{N A}$ \\
\hline
\end{tabular}

$\mathrm{ND}=$ Not Detected; NA=Not Applicable

*: Analysis performed on-site at time of sampling.

** For $11 / 21 / 90$ only 
Table 40. Groundwater Analysis for Well TW\#3

\begin{tabular}{|c|c|c|c|c|c|c|}
\hline & \begin{tabular}{|c|} 
Collection Date \\
......... \\
\end{tabular} & $2 / 12 / 90$ & $5 / 18 / 90$ & $8 / 13 / 90$ & $11 / 21 / 90$ & $\begin{array}{l}\text { Detection } \\
\text { Limit * }\end{array}$ \\
\hline Units & Parameter & & & & & \\
\hline $\mathrm{mg} / \mathrm{l}$ & \begin{tabular}{|l} 
Chloride \\
\end{tabular} & & & 6 & 26 & 3 \\
\hline $\mathrm{mg} / \mathrm{l}$ & $\begin{array}{l}\text { Lead, } \\
\text { Dissolved }\end{array}$ & & & $<0.05$ & ND & \\
\hline $\mathrm{mg} / \mathrm{I}$ & $\begin{array}{l}\text { Nitrogen, } \\
\text { Ammonia }\end{array}$ & & 0.1 & $<0.10$ & ND & 0.5 \\
\hline $\mathrm{mg} / \mathrm{l}$ & \begin{tabular}{|l|} 
Nitrogen, \\
Nitrate
\end{tabular} & & & 0.2 & ND & 1 \\
\hline $\mathrm{mg} / \mathrm{l}$ & $\begin{array}{l}\text { Organic } \\
\text { Carbon, Total }\end{array}$ & & & 3 & & \\
\hline $\mathrm{mg} / \mathrm{I}$ & $\begin{array}{l}\text { Organic } \\
\text { Halides, Total }\end{array}$ & & & $<30.0$ & & \\
\hline $\mathrm{mg} / \mathrm{l}$ & $\begin{array}{l}\text { Petroleum } \\
\text { Hydrocarbons, } \\
\text { Total }\end{array}$ & & & $<0.5$ & & \\
\hline unit & $\mathrm{pH}$ & 6.5 & & & $6.7^{*}$ & $\overline{N A}$ \\
\hline $\mathrm{mg} / 1$ & $\begin{array}{l}\text { Phenols, } \\
\text { Distillation } \\
\end{array}$ & & & $<0.10$ & ND & 0.2 \\
\hline $\mathrm{mg} / \mathrm{l}$ & $\begin{array}{l}\text { Solids - } \\
\text { Dissolved, } \\
\text { Total } \\
\end{array}$ & 222 & 246 & 218 & 180 & 5 \\
\hline$\mu \mathrm{mho} / \mathrm{cm}$ & $\begin{array}{l}\text { Specific } \\
\text { Conductance @ } \\
25 \mathrm{C}\end{array}$ & 312 & & & 310 & NA \\
\hline $\mathrm{mg} / \mathrm{l} \mathrm{SO}{ }_{4}$ & $\begin{array}{l}\text { Sulfate, } \\
\text { Dissolved }\end{array}$ & 22 & 23 & 27 & 20 & 5 \\
\hline Deg.C & Temperature & & & & $12^{*}$ & NA \\
\hline
\end{tabular}

$\mathrm{ND}=$ Not Detected; NA=Not Applicable

*: Analysis performed on-site at time of sampling.

** For $11 / 21 / 90$ only 
Table 41. Groundwater Analysis for Well \#W4 and \#W5.

\begin{tabular}{|c|c|c|c|c|c|c|c|}
\hline & \begin{tabular}{|l} 
Collection Date \\
......... \\
\end{tabular} & $3 / 22 / 90$ & $3 / 22 / 90$ & $5 / 23 / 90$ & $5 / 23 / 90$ & $8 / 20 / 90$ & $8 / 20 / 90$ \\
\hline Units & \begin{tabular}{|l} 
Parameter \\
\end{tabular} & W-4 & W-5 & $W-4$ & W-5 & $W-4$ & W.5 \\
\hline $\mathrm{mg} / 1$ & Alkalinity & 1 & 46 & & & & \\
\hline $\mathrm{mg} / \mathrm{l}$ & $\mathrm{BOD}_{5}$ & & & $<1.0$ & $<1.0$ & 2.5 & 6.4 \\
\hline $\mathrm{mg} / 1$ & $\infty$ & & & $<5.0$ & $<5.0$ & 20 & 10 \\
\hline $\mathrm{mg} / \mathrm{l}$ & $\begin{array}{l}\text { Calcium } \\
\text { Hardness }\end{array}$ & 70 & 34 & & & & \\
\hline $\mathrm{mg} / 1$ & Copper & $<0.02$ & $<0.02$ & & & & \\
\hline $\mathrm{mg} / \mathrm{l}$ & Coliform Total & 11 & $<2$ & & & & \\
\hline $\mathrm{mg} / \mathrm{l}$ & Iron & 4.5 & 0.33 & & & & \\
\hline $\mathrm{mg} / \mathrm{l}$ & \begin{tabular}{|l|} 
Kjedahl \\
Nitrogen Total \\
\end{tabular} & 0.5 & $<0.1$ & & & & \\
\hline $\mathrm{mg} / \mathrm{l}$ & $\begin{array}{l}\text { Nitrogen, } \\
\text { Ammonia } \\
\end{array}$ & & & 0.11 & 0.36 & $<0.10$ & $<0.10$ \\
\hline $\mathrm{mg} / \mathrm{l}$ & $\begin{array}{l}\text { Nitrate, } \\
\text { Nitrogen }\end{array}$ & 0.11 & 1.6 & & & & \\
\hline $\mathrm{mg} / \mathrm{l}$ & $\mathrm{pH}$ & 7.3 & 6.3 & 6.9 & 6 & 6.9 & 6.1 \\
\hline $\mathrm{mg} / \mathrm{l}$ & $\begin{array}{l}\text { Petroleum } \\
\text { Hydrocarbons, } \\
\text { Total }\end{array}$ & & & $<0.5$ & $<0.5$ & $<0.50$ & $<0.50$ \\
\hline $\mathrm{mg} / 1$ & Phenols, Total & & & $<0.10$ & $<0.10$ & $<0.10$ & $<0.10$ \\
\hline $\mathrm{mg} / \mathrm{I}$ & $\begin{array}{l}\text { Phosphate } \\
\text { Total }\end{array}$ & 0.2 & 0.2 & & & & \\
\hline $\mathrm{mg} / \mathrm{I}$ & $\begin{array}{l}\text { Ortho } \\
\text { Phosphate }\end{array}$ & $<0.1$ & 0.1 & & & & \\
\hline $\mathrm{mg} / \mathrm{l}$ & $\begin{array}{l}\text { Solids, } \\
\text { Dissolved Total }\end{array}$ & 161 & 100 & 183 & 127 & 190 & 116 \\
\hline $\mathrm{mg} / \mathrm{l}$ & $\begin{array}{l}\text { Solids, } \\
\text { Settleable }\end{array}$ & & & $<0.10$ & $<0.10$ & & \\
\hline $\mathrm{mg} / \mathrm{l}$ & $\begin{array}{l}\text { Solids, } \\
\text { Suspended } \\
\text { Total } \\
\end{array}$ & & & & & 12 & 4 \\
\hline $\mathrm{mg} / \mathrm{l}$ & Manganese & 0.11 & $<0.01$ & & & & \\
\hline $\mathrm{mg} / \mathrm{l}$ & Chloride & 10 & 5 & & & & \\
\hline $\mathrm{mg} / \mathrm{l}$ & Sulfate & 10 & 12 & & & & \\
\hline $\mathrm{mg} / \mathrm{l}$ & Temperature & 12 & 12 & & & & \\
\hline $\mathrm{mg} / \mathrm{l}$ & Turbidity & 4.7 & 2.6 & & & & \\
\hline
\end{tabular}




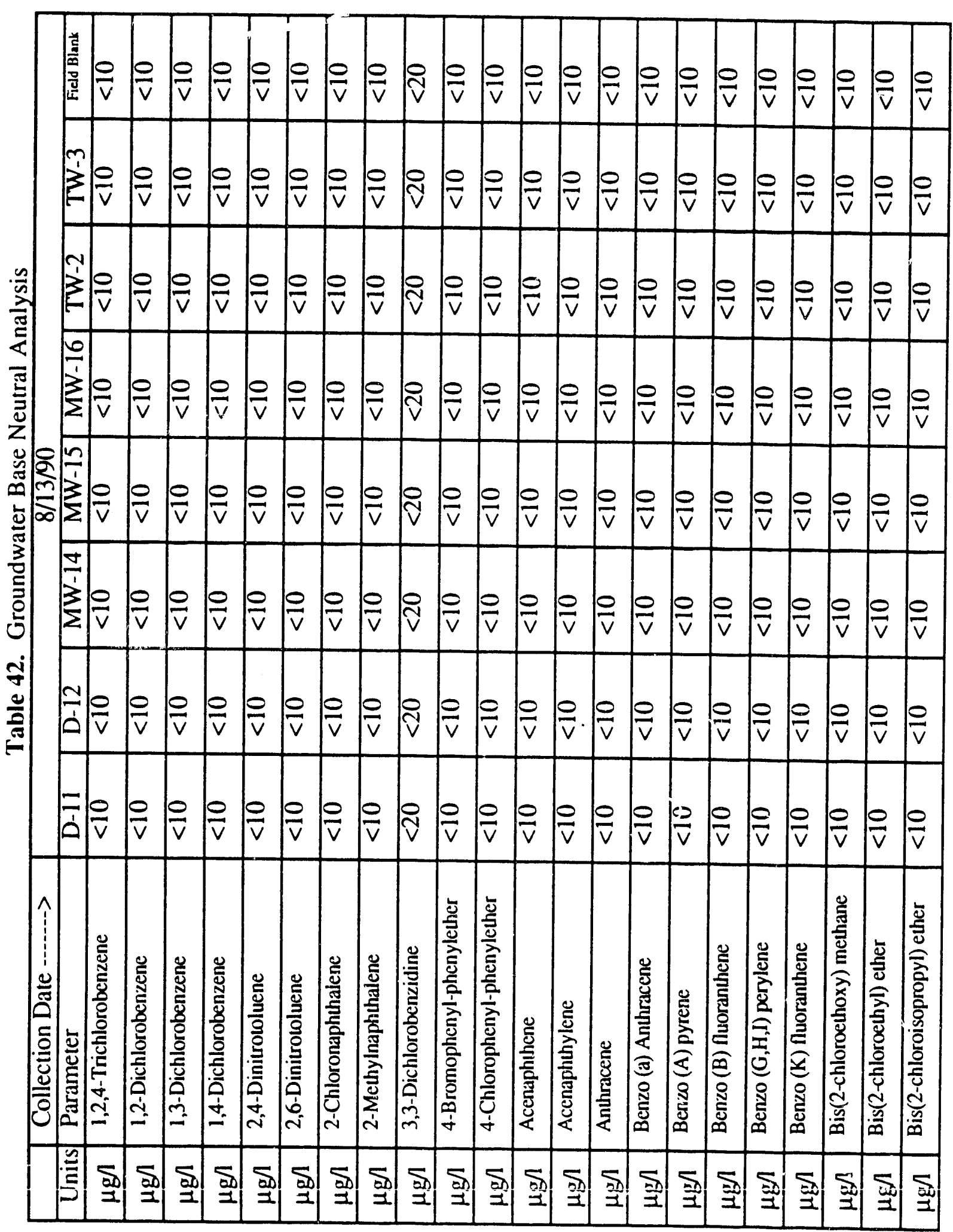




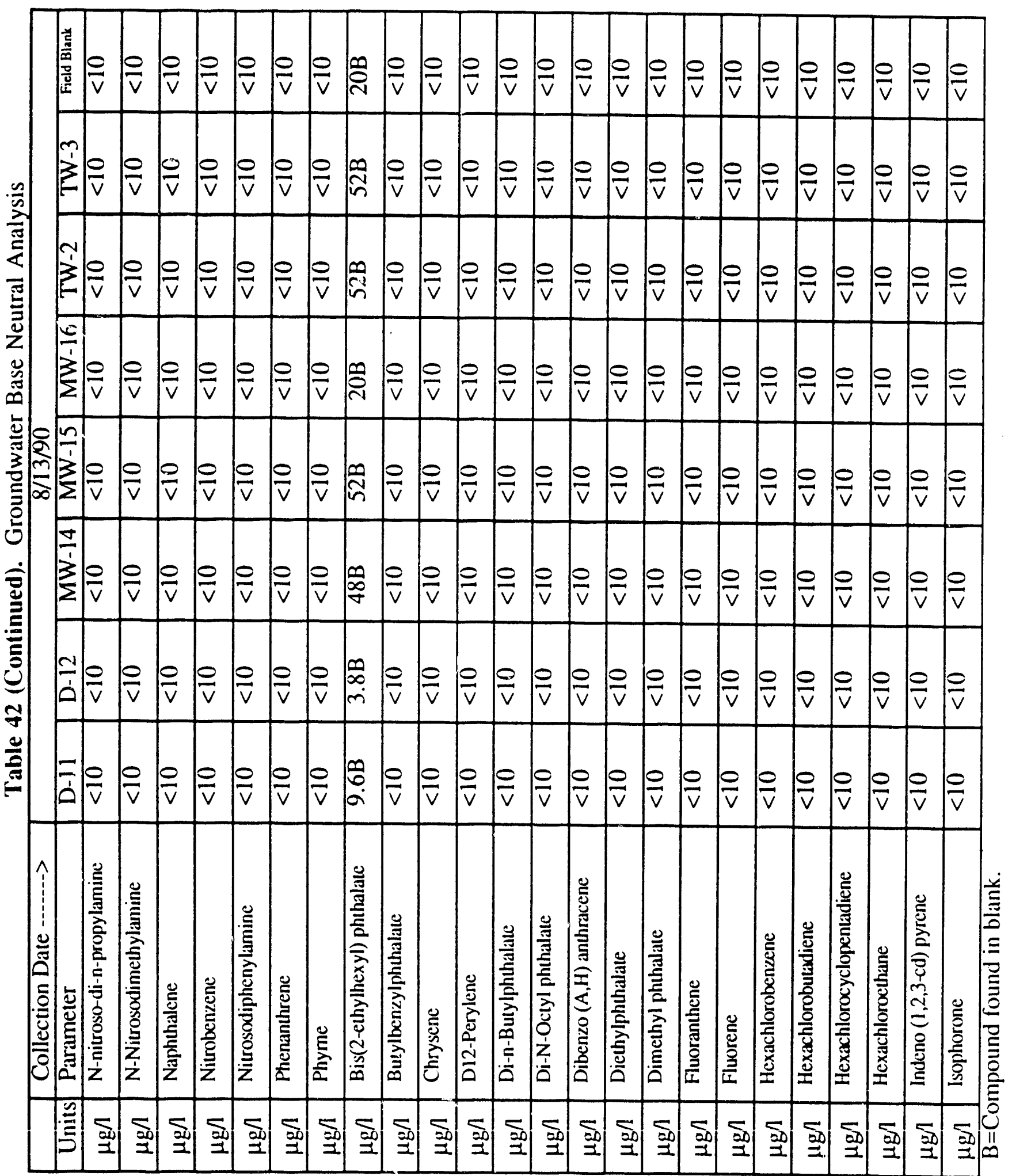




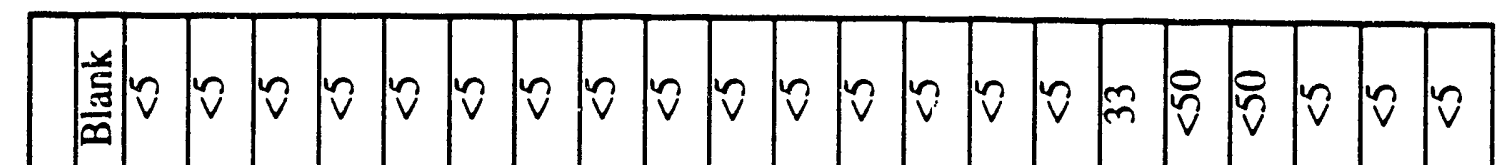

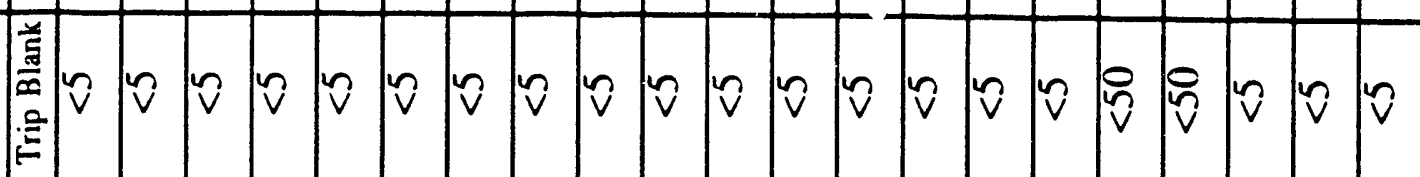

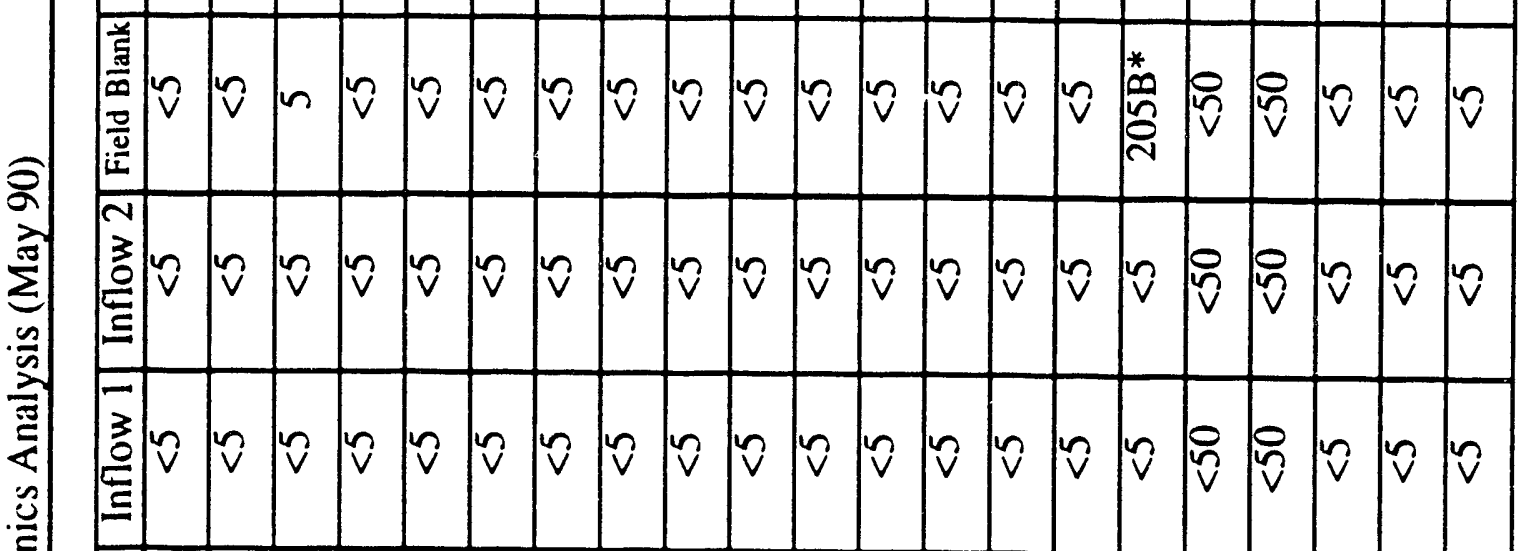
(2)

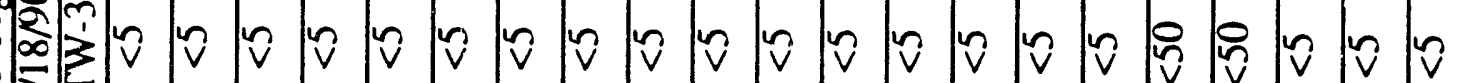

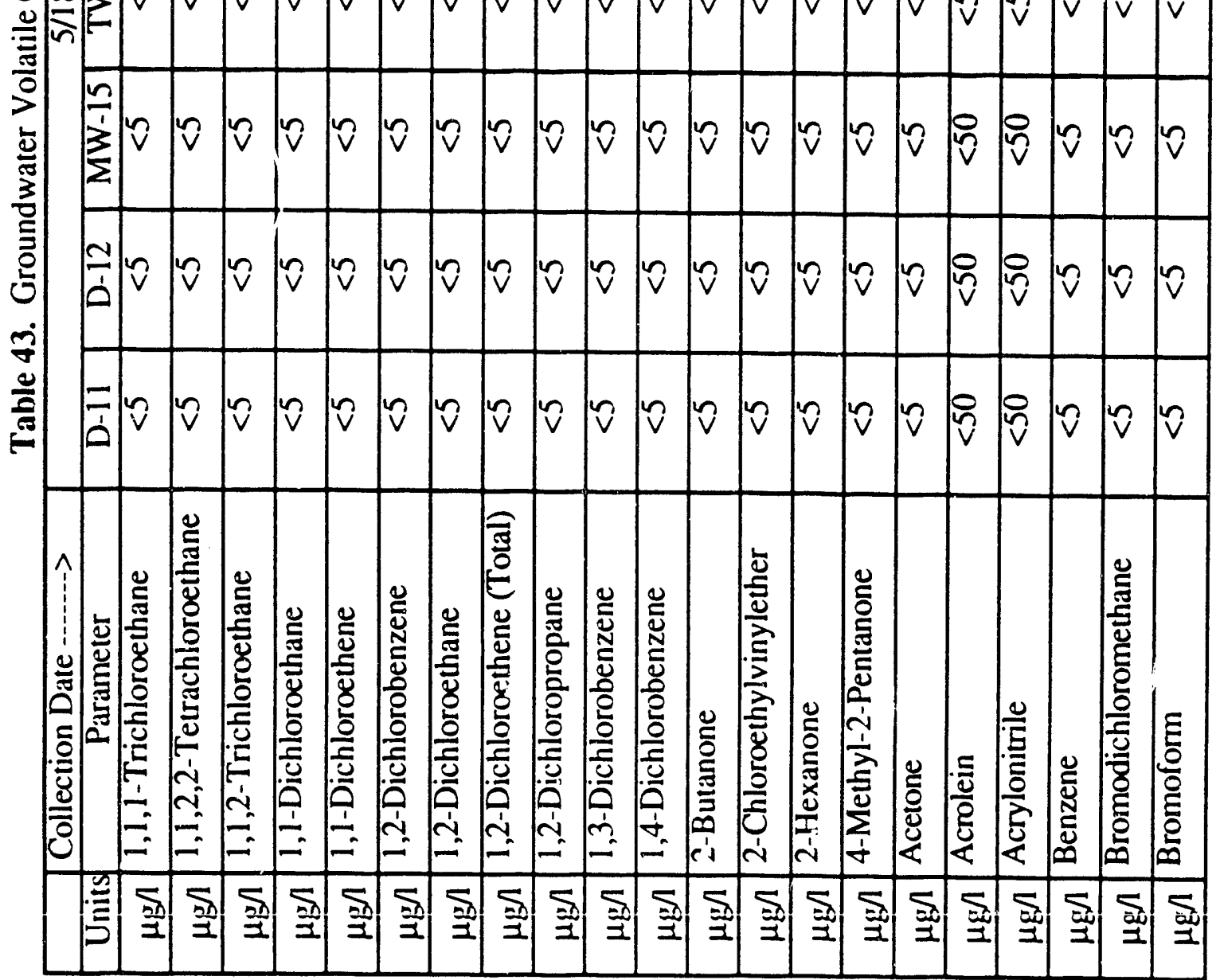




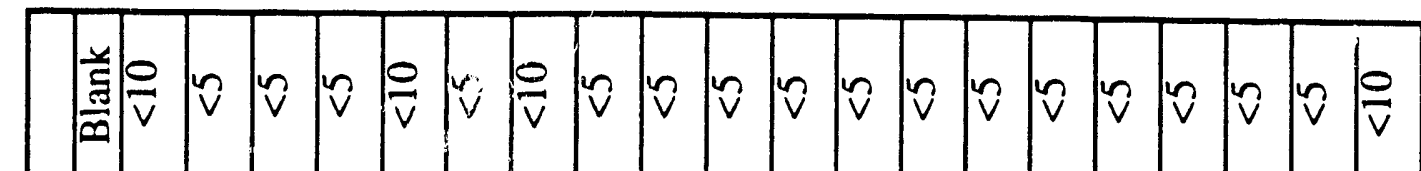

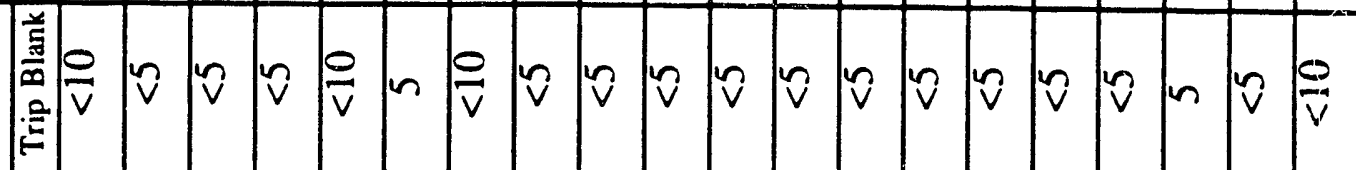

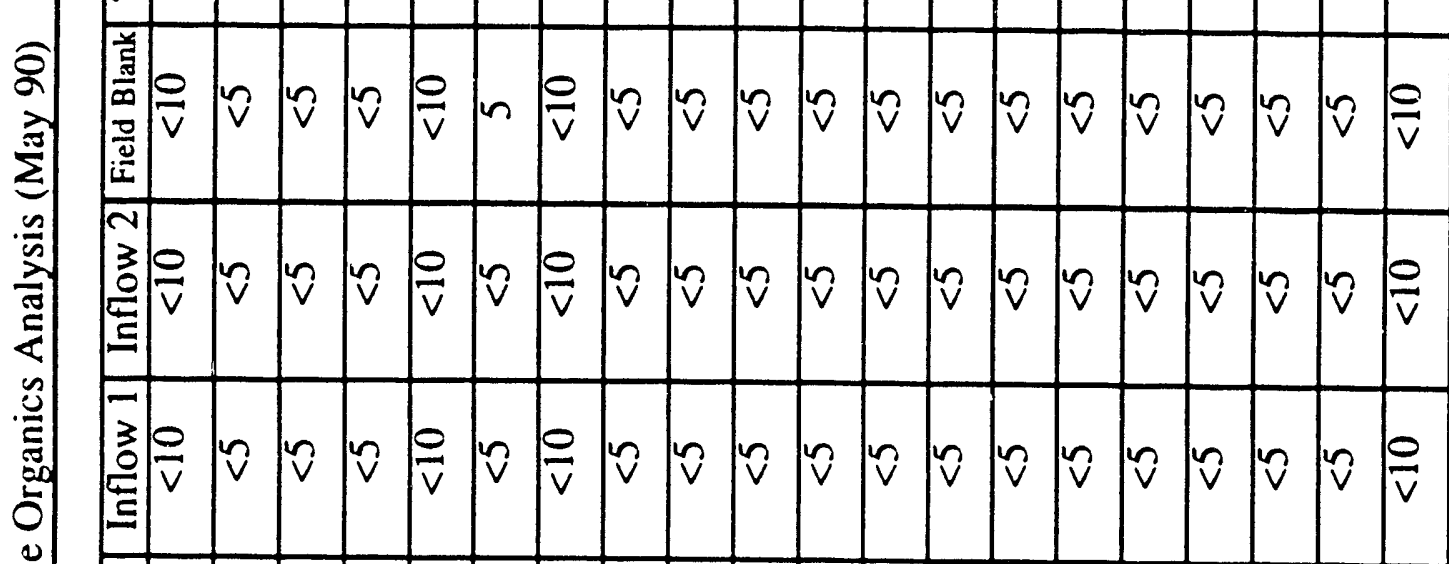
:

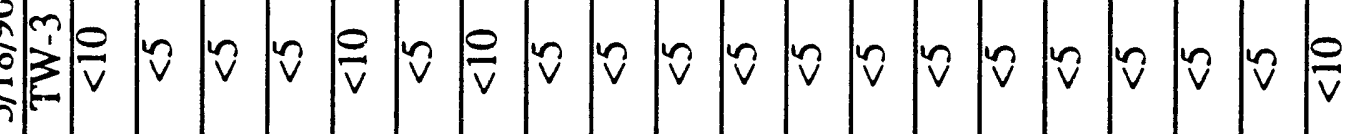

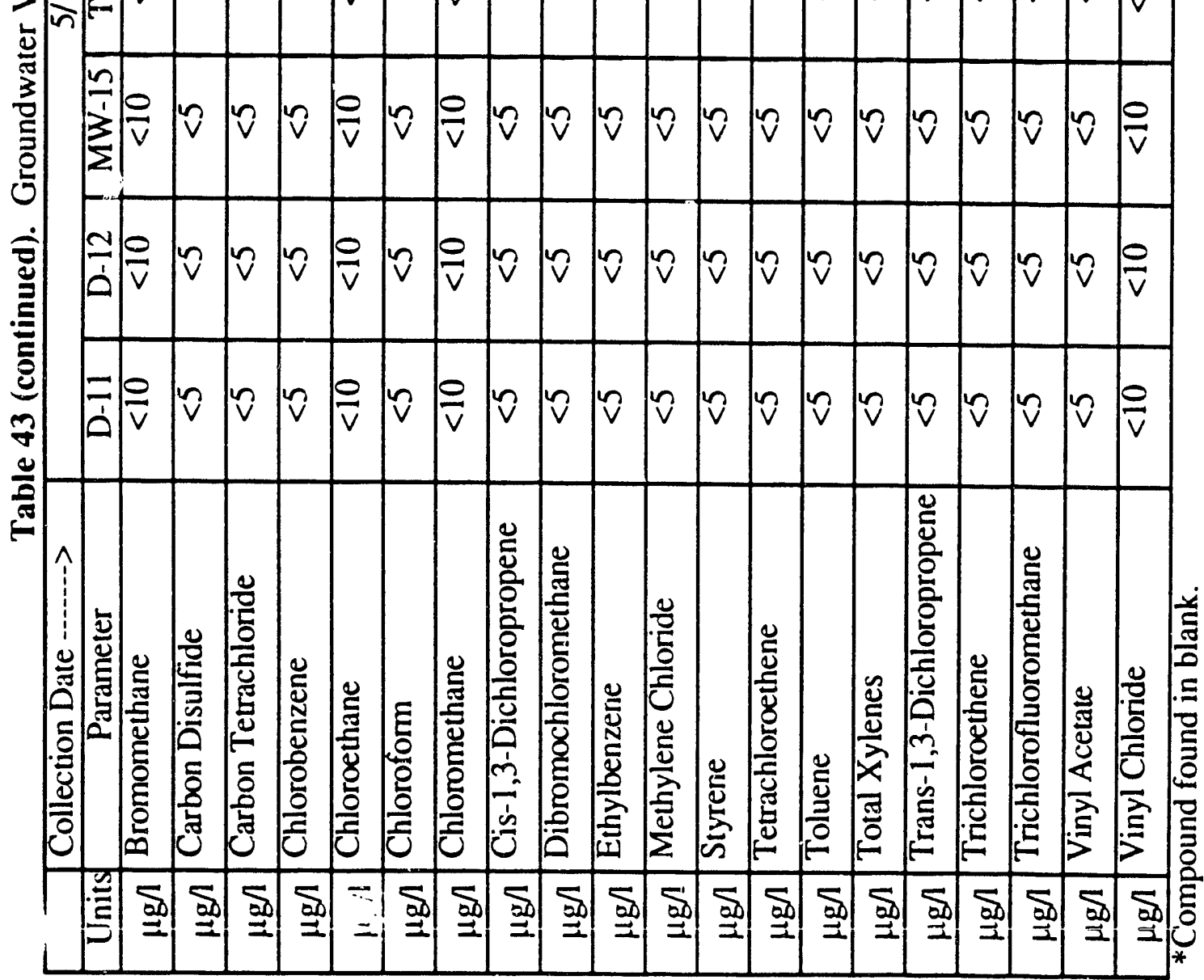


Table 44. Groundwater Volatile Organics Analysis (August 90)

\begin{tabular}{|c|c|c|c|c|c|c|c|}
\hline & Collection Date ........ & & & $3 / 13 / 90$ & & & \\
\hline Units & Parameter & 0.11 & $D-12$ & $M W-15$ & TW-3 & Inflow 1 & Inflow 2 \\
\hline$\mu g / 1$ & 1,1,1-Trichloroethane & $<5$ & $<5$ & $<5$ & $<5$ & $<5$ & $<5$ \\
\hline$\mu g / 1$ & 1,1,2,2-Tetrachloroethane & $<5$ & $<5$ & $<5$ & $<5$ & $<5$ & 7 \\
\hline$\mu g / 1$ & 1,1,2-Trichloroethan $\theta$ & $<5$ & $<5$ & $<5$ & $<5$ & $<5$ & $<5$ \\
\hline$\mu g / 1$ & 1,1-Dichloroethane & $<5$ & 14 & $<5$ & $<5$ & $<5$ & $<5$ \\
\hline$\mu g / l$ & 1,1-Dichloroethene & $<5$ & 13 & $<5$ & $<5$ & $<5$ & $<5$ \\
\hline$\mu g / l$ & 1,2-Dichlorobenzene & $<5$ & $<5$ & $<5$ & $<5$ & $<5$ & $<5$ \\
\hline$\mu g / 1$ & 1,2-Dichloroethane & $<5$ & $<5$ & $<5$ & $<5$ & $<5$ & $<5$ \\
\hline$\mu g / 1$ & 1,2-Dichloroethene (Total) & $<5$ & $<5$ & $<5$ & $<5$ & $<5$ & $<5$ \\
\hline$\mu g / 1$ & 1,2-Dichloropropane & $<5$ & $<5$ & $<5$ & $<5$ & $<5$ & $<5$ \\
\hline$\mu g / 1$ & 1,3-Dichlorobenzene & $<5$ & $<5$ & $<5$ & $<5$ & $<5$ & $<5$ \\
\hline$\mu g / 1$ & 1,4-Dichlorobenzene & $<5$ & $<5$ & $<5$ & $<5$ & $<5$ & $<5$ \\
\hline$\mu g / 1$ & 2-Butanone & $<5$ & $<5$ & $<5$ & $<5$ & $<5$ & $<5$ \\
\hline$\mu g / l$ & 2-Chloroethylvinylether & $<5$ & $<5$ & $<5$ & $<5$ & $<5$ & $<5$ \\
\hline$\mu g / l$ & 2-Hexanone & $<5$ & $<5$ & $<5$ & $<5$ & $<5$ & $<5$ \\
\hline$\mu g / 1$ & 4-Methyl-2-Pentanone & 5.6 & 12 & $<5$ & $<5$ & $<5$ & 6 \\
\hline$\mu g / 1$ & Acetone & $17 \mathrm{~B}^{\circ}$ & $<5$ & $<5$ & $11 B^{\circ}$ & $<5$ & $<5$ \\
\hline$\mu g / 1$ & Acrolein & $<50$ & $<50$ & $<50$ & $<50$ & $<50$ & $<50$ \\
\hline$\mu g / 1$ & Acrylonitrile & $<50$ & $<50$ & $<50$ & $<50$ & $<50$ & $<50$ \\
\hline$\mu g / 1$ & Benzene & $<5$ & $<5$ & $<5$ & $<5$ & $<5$ & $<5$ \\
\hline$\mu g / 1$ & Bromodichloromethane & $<5$ & $<5$ & $<5$ & $<5$ & $<5$ & $<5$ \\
\hline$\mu \mathrm{g} / \mathrm{I}$ & Bromoform & $<5$ & $<\Xi$ & $<5$ & $<5$ & $<5$ & $<5$ \\
\hline$\mu \mathrm{g} / \mathrm{I}$ & Bromomethane & $<10$ & $<10$ & $<10$ & $<10$ & $<10$ & $<10$ \\
\hline$\mu \mathrm{g} / \mathrm{I}$ & Carbon Disulfide & $<5$ & $<5$ & $<5$ & $<5$ & $<5$ & $<5$ \\
\hline$\mu g / 1$ & Carbon Tetrachloride & $<5$ & $<5$ & $<5$ & $<5$ & $<5$ & $<5$ \\
\hline$\mu g / 1$ & Chlorobenzene & $<5$ & $<5$ & $<5$ & $<5$ & $<5$ & $<5$ \\
\hline$\mu g / 1$ & Chloroethane & $<10$ & $<10$ & $<10$ & $<10$ & $<10$ & $<10$ \\
\hline$\mu g / 1$ & Chloroform & $<5$ & $<5$ & $<5$ & $<5$ & $<5$ & $<5$ \\
\hline$\mu g / 1$ & Chloromethane & $<10$ & $<10$ & $<10$ & $<10$ & $<10$ & $<10$ \\
\hline$\mu \mathrm{g} / \mathrm{l}$ & Cis-1,3-Dichloropropene & $<5$ & $<5$ & $<5$ & $<5$ & $<5$ & $<5$ \\
\hline$\mu g / 1$ & Dibromochloromethane & $<5$ & $<5$ & $<5$ & $<5$ & $<5$ & $<5$ \\
\hline$\mu g / 1$ & Ethylbenzene & $<5$ & $<5$ & $<5$ & $<5$ & $<5$ & $<5$ \\
\hline$\mu \mathrm{g} / \mathrm{l}$ & Methylene Chloride & $5.6 \mathrm{~B}^{\circ}$ & $<5$ & $4.7 \mathrm{JB}^{\circ}$ & $6.78^{\circ}$ & $<5$ & $<5$ \\
\hline$\mu \mathrm{g} / \mathrm{l}$ & Styrene & $<5$ & $<5$ & $<5$ & $<5$ & $<5$ & $<5$ \\
\hline$\mu g / 1$ & Tetrachloroethene & 5.6 & 12 & $<5$ & $<5$ & 26 & $<5$ \\
\hline$\mu g / 1$ & Tolvene & $<5$ & $<5$ & $<5$ & $<5$ & $<5$ & $<5$ \\
\hline$\mu g / 1$ & Total Xylenes & $<5$ & $<5$ & $<5$ & $<5$ & $<5$ & $<5$ \\
\hline$\mu \mathrm{g} / \mathrm{I}$ & Trans-1,3-Dichloropropene & $\leq 5$ & 5 & $<5$ & $<5$ & $<5$ & $<5$ \\
\hline$\mu g / 1$ & Trichloroethene & $<5$ & 5 & $<5$ & $<5$ & $<5$ & $<5$ \\
\hline$\mu g / 1$ & Trichlorofluoromethane & $<5$ & $<5$ & $=5$ & $<5$ & $<5$ & $<5$ \\
\hline$\mu g / 1$ & Vinyl Acetate & $<5$ & $<5$ & $<5$ & $<5$ & $<5$ & $<5$ \\
\hline$\mu g / 1$ & Vinyl Chloride & $<10$ & $<10$ & $<10$ & $<10$ & $<10$ & $<10$ \\
\hline
\end{tabular}

$\mathrm{B}=$ Compound found in blank; $\mathrm{J}=$ Estimated value (detected below quantitation limits). 
Table 45. Miscellaneous Data for Groundwater Wells

\begin{tabular}{|c|c|c|c|c|c|c|c|}
\hline & Collection Date & & & $11 / 21 / 90$ & & & \\
\hline Units" & Parameter & $T W-1$ & $T W-10$ & Blank & $B \operatorname{lan} k$ & Blank & Limit \\
\hline $\mathrm{mg} / \mathrm{l}$ & Chloride & 24 & 14 & ND & ND & 3 & 3 \\
\hline $\mathrm{mg} / \mathrm{I}$ & $\begin{array}{l}\text { Chromium - } \\
\text { Hexavalent }\end{array}$ & & & & & & 25 \\
\hline umhos $/ \mathrm{cm}^{*}$ & Conductivity & 280 & 280 & 0 & & & NA \\
\hline $\mathrm{mg} / \mathrm{l}$ & $\begin{array}{l}\text { Lead, } \\
\text { Dissolved }\end{array}$ & ND & ND & ND & & & 5 \\
\hline $\mathrm{mg} / \mathrm{l}$ & $\begin{array}{l}\text { Nitrogen, } \\
\text { Ammonia } \\
\end{array}$ & ND & ND & 1.8 & ND & 0.5 & 0.5 \\
\hline $\mathrm{mg} / \mathrm{I}$ & $\begin{array}{l}\text { Nitrogen, } \\
\text { Nitrate }\end{array}$ & ND & 1.1 & ND & ND & 1 & 1 \\
\hline $\mathrm{mg} / \mathrm{l}$ & $\mathrm{pH}$ & 6.9 & 6.7 & 4.4 & & & NA \\
\hline $\mathrm{mg} / \mathrm{l}$ & Phenols, Total & ND & $\mathrm{ND}$ & $\mathrm{ND}$ & $\overline{N D}$ & $\overline{0.2}$ & 0.2 \\
\hline $\mathrm{mg} / \mathrm{l}$ & $\begin{array}{l}\text { Solids - } \\
\text { Dissolved }\end{array}$ & 180 & 190 & ND & ND & 5 & 5 \\
\hline $\mathrm{mg} / 1$ & Sulfate & 20 & 18 & $\overline{N D}$ & $\overline{N D}$ & 5 & 5 \\
\hline $\mathrm{mg} / \mathrm{I}$ & Temperature & 12 & 12 & 20 & & & NA \\
\hline
\end{tabular}

$\mathrm{ND}=$ Not Detected; $\mathrm{NA}=$ Not Applicable

*: Analysis performed on-site at time of sampling. 
Table 46. General Chemistry for Groundwater Wells

\begin{tabular}{|c|c|c|c|c|c|c|}
\hline & Collection Date & & & $1 / 29 / 90$ & & \\
\hline Units & Parameter & $\mathrm{D}-11$ & $\overline{D-12}$ & Sump & Field Blank & Trip Bla \\
\hline $\mathrm{mg} / \mathrm{s}$ & Barium & 1.2 & $<0.10$ & 0.25 & $<0.10$ & $<0.10$ \\
\hline $\mathrm{mg} / \mathrm{l}$ & Titanium & 20.05 & $<0.05$ & $<0.05$ & $<0.05$ & $<0.05$ \\
\hline $\mathrm{mg} / \mathrm{l}$ & Beryll & 0.05 & & 0.05 & $<0.05$ & $<0.05$ \\
\hline $\mathrm{mg} /$ & Cadmium & $<0.01$ & $<0.01$ & $<0.01$ & $<L .01$ & $<0.01$ \\
\hline $\mathrm{mg} / \mathrm{I}$ & rromiu & $<0.02$ & $<0$. & $<0.02$ & $<0.02$ & $<0.02$ \\
\hline $\mathrm{mg} / \mathrm{L}$ & Copper & 0.06 & $<0.02$ & 0.4 & $<0.02$ & $<0.02$ \\
\hline $\mathrm{mg} / \mathrm{s}$ & Nickel & $<0.04$ & $<0.04$ & $<0.04$ & $<0.04$ & $<0.04$ \\
\hline $\mathrm{mg} / \mathrm{l}$ & Lead & $<0.02$ & $<0.02$ & 0.02 & $<0.02$ & $<0.02$ \\
\hline $\mathrm{mg} / \mathrm{l}$ & Zinc & 0.06 & $<0.02$ & 0.5 & $<0.02$ & $<0.02$ \\
\hline $\mathrm{mg} / \mathrm{I}$ & Arsenic & $<0.01$ & $<0.01$ & $<0.01$ & $<0.01$ & $<0.01$ \\
\hline $\mathrm{mg} / \mathrm{l}$ & Silver & $\pi$ & $<0.01$ & $<0.01$ & 0.01 & 0.01 \\
\hline$\overline{\mathrm{mg} / \mathrm{l}}$ & Antimony & $<0.06$ & $<0.06$ & $<0.06$ & & $<0.06$ \\
\hline $\mathrm{mg} / \mathrm{l}$ & Seleni & $<0.01$ & $<0.01$ & $<0.01$ & $<0.01$ & $<0.01$ \\
\hline $\mathrm{mg} / \mathrm{s}$ & Thallium & $<0.01$ & $<0.01$ & $<0.01$ & $<0.01$ & $<0.01$ \\
\hline $\mathrm{mg} / \mathrm{l}$ & Mercury & $<0.001$ & $<0.001$ & $<0.001$ & $<0.001$ & $<0.001$ \\
\hline$\overline{\mathrm{g} \Omega}$ & Lead, Filterec & $<0.02$ & $<0.02$ & $<0.02$ & $<0.02$ & $<0.02$ \\
\hline
\end{tabular}


Table 47

FERTILIZER, PESTICIDES, AND HERBICIDE APPLICATION [Ra91]

\begin{tabular}{|c|c|c|c|}
\hline DATE & LOCATION & PRODUCT & AMOUNT \\
\hline \multicolumn{4}{|c|}{ EERTULIZER } \\
\hline $4 / 22 / 90$ & C \& D Sites & Morral 16-0-4 & 77 gals. \\
\hline \multicolumn{4}{|c|}{ PESTICIDES } \\
\hline $\begin{array}{l}10 / 26 / 90 \\
10 / 31 / 90 \\
11 / 6 / 90 \\
11 / 15 / 90\end{array}$ & $\begin{array}{l}\text { C Site (Rm. 145) } \\
\text { C Site-PM\&E } \\
\text { C Site-Eng. Wing } \\
\text { C Site Control House } \\
\text { C-Site Kitchen/Cafe. } \\
\text { C-Site QA Trailers } \\
\text { C-site MOD.2 }\end{array}$ & $\begin{array}{l}2 \% \text { Cynoff EC } \\
2 \% \text { Cynoff EC } \\
2 \% \text { Cynoff EC } \\
\text { Bell Block Bait } \\
\text { Tempo } 2 \\
\text { Baton Block Bait }\end{array}$ & $\begin{array}{l}4 \text { oz. } \\
44 \text { oz. } \\
4 \text { oz. } \\
4 \text { sqs. } \\
1 \text { gal. } \\
4 \text { oz. }\end{array}$ \\
\hline $12 / 4 / 90$ & $\begin{array}{l}\text { Theory Wing } \\
\text { C-Site Kitchen/Cafe } \\
\text { ". }\end{array}$ & $\begin{array}{l}\text { Cynoff EC }(.2 \% / \mathrm{gal}) \\
\text { Dursban }(.5 \% / \mathrm{gal}) \\
\text { Orthene Pt } 280 \text { aerosal } \\
\text { Roach Router aerosal }\end{array}$ & $\begin{array}{l}12 \mathrm{oz} \\
2 \mathrm{qt} . \\
5 \mathrm{oz} . \\
3 \mathrm{oz}\end{array}$ \\
\hline $12 / 5 / 90$ & $\begin{array}{l}\text { C-Site-NEW } \\
\text { Cubicle W,V,O,Y }\end{array}$ & It Works Ant Bait & $6 \mathrm{oz}$ \\
\hline 1990 & D Site & No pesticides applied & \\
\hline \multicolumn{4}{|c|}{ HERBICIDES } \\
\hline DATE & LOCATION & PRODUCT & AMOUNT \\
\hline $4 / 22 / 90$ & $\begin{array}{l}\text { C \& D Sites } \\
\text { All turfed } \\
\text { areas }\end{array}$ & $\begin{array}{l}\text { Trimec } 899 \\
\text { Pre-M Crabgrass }\end{array}$ & $\begin{array}{l}1.85 \text { gals. } \\
8.9 \text { gals } \\
\text { (Total mixture) } \\
\text { with water \& fert. } \\
=475 \text { gals.) }\end{array}$ \\
\hline $6 / 2 \& 6 / 16$ & $\begin{array}{l}\text { C \& D Sites } \\
\text { Nonturfed } \\
\text { stone areas }\end{array}$ & $2 \%$ Round-Up* & $\begin{array}{l}8.0 \text { gals. } \\
\text { (Total mixture } \\
\text { with water = } \\
400 \text { gals.) }\end{array}$ \\
\hline $9 / 13 / 90$ & $\begin{array}{l}\text { C \& D Sites } \\
\text { All stoned } \\
\text { areas }\end{array}$ & $\begin{array}{l}1 \% \text { Round-Up* } \\
\text { and Oust }\end{array}$ & $\begin{array}{l}4.5 \text { gals. } \\
3.0 \mathrm{lbs} \\
\text { (Total mixturewith } \\
\text { water }=600 \text { gals.) }\end{array}$ \\
\hline
\end{tabular}

* Round-Up applications were done on selected nonturfed areas - primarily stoned parking lots and road shoulders. Round-Up applications were prohibited in the detention basin and areas surrounding it. 
Table 48. PPPL REML QA/QC from EPA/Las Vegas and DOE/EML*

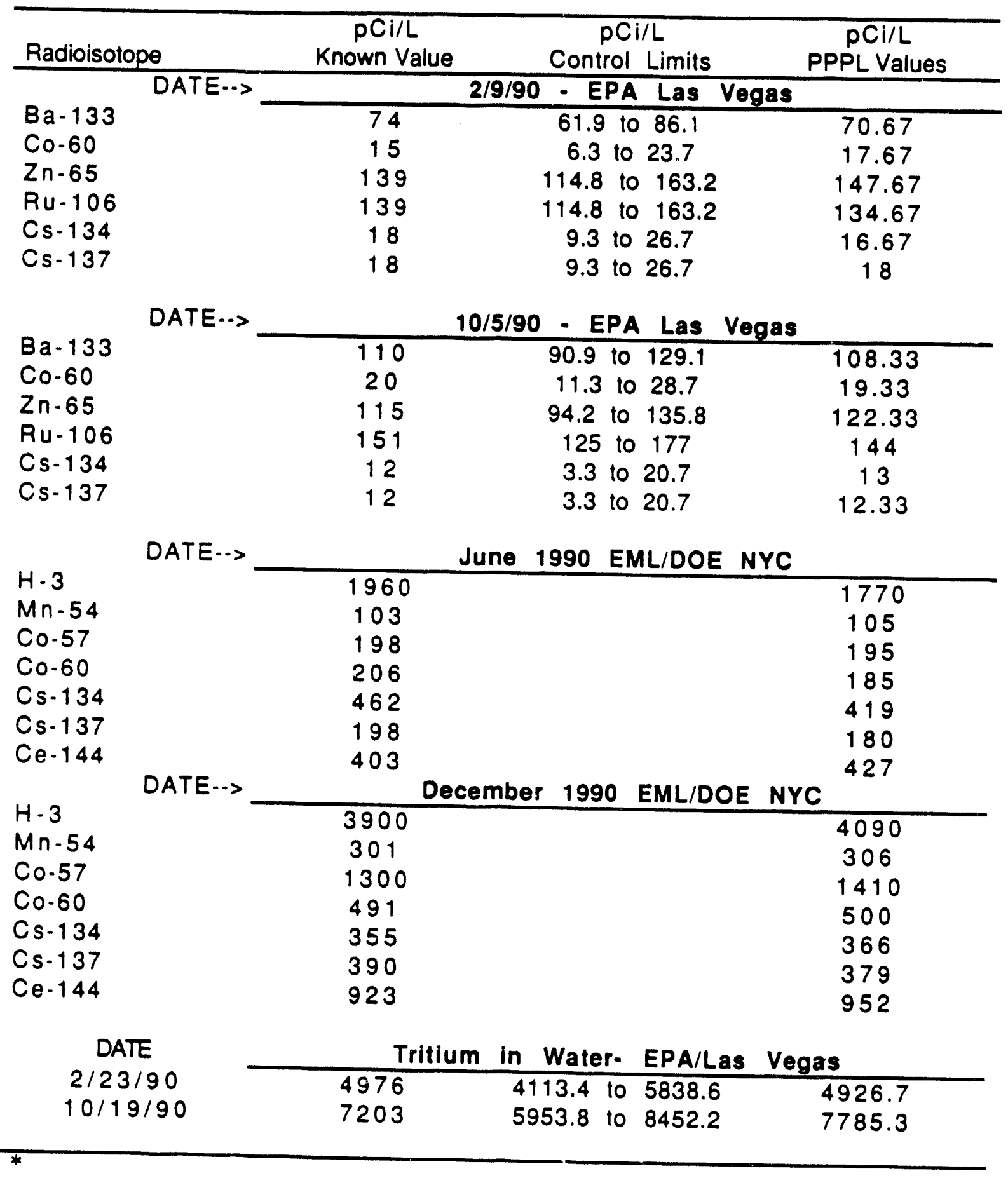

REML = PPPL Radiological Environmental Monitoring Laboratory

EPA/Las Vegas = Environmental Protection Agency's Laboratory in Las Vegas

$\mathrm{DOE} / \mathrm{EML}=$ The Department of Energy's Environmental Measurements Lab in New York City 
Table 49. Split Sample QA Data

\begin{tabular}{|c|c|c|c|c|c|}
\hline & Collection Date $\cdots>$ & $2 / 26 / 90$ & $2 / 20 / 90$ & $8 / 20 / 90$ & $8 / 20 / 90$ \\
\hline Units & Parameter & $\overline{Q A-1}$ & UA-2 & QA-1 & QA.2 \\
\hline $\mathrm{mg} / \mathrm{l} \mathrm{CaCO}_{3}$ eq. & Alkalinity & 16 & 12 & & \\
\hline $\mathrm{mg} / \mathrm{lo}$ & $\mathrm{BOD5}$ & $<1$ & $<1$ & 2.3 & 2.6 \\
\hline $\mathrm{mg} / \mathrm{lCaCO}{ }_{3}$ eq. & Calcium Hardness & 15 & 15 & & \\
\hline $\mathrm{mg} / \mathrm{l} \mathrm{Cr}$ & \begin{tabular}{|l} 
Chromium - Total \\
\end{tabular} & $\leq 0.02$ & $<0.02$ & $<0.02$ & $<0.02$ \\
\hline $\mathrm{mg} / \mathrm{l} \mathrm{Cr}$ & $\begin{array}{l}\text { Chromium - } \\
\text { Hexavalent }\end{array}$ & $<0.02$ & & & \\
\hline $\mathrm{mg} / 1 \mathrm{O}_{2}$ & $\mathrm{COD}$ & $<5.0$ & $<5.0$ & 30 & 20 \\
\hline $\mathrm{mg} / \mathrm{Cu}$ & Copper & 0.02 & $<0.02$ & & \\
\hline $\mathrm{mg} / 1 \mathrm{O}_{2}$ & Dissolved Oxygen & 11 & 11 & & \\
\hline $\mathrm{mg} / \mathrm{Cu}$ eq. & EDTA & 0.56 & 0.36 & & \\
\hline MPN/100 ml & Total Coliform Count & 2 & 4 & & \\
\hline $\mathrm{ft}^{3} / \mathrm{sec}$ & Flow & $\mathrm{NA}^{*}$ & $\mathrm{NA}^{*}$ & & \\
\hline $\mathrm{mg} / / \mathrm{Fe}$ & Iron & 0.15 & 0.14 & & \\
\hline $\mathrm{mg} / \mathrm{l}$ & Nitrogen, Ammonia & & & 0.11 & $<0.10$ \\
\hline $\mathrm{mg} / \mathrm{N}$ & \begin{tabular}{|l|}
$\begin{array}{l}\text { Nitrogen, Total } \\
\text { Kjedahl }\end{array}$ \\
\end{tabular} & 1 & 0.62 & & \\
\hline $\mathrm{mg} / \mathrm{l} \mathrm{N}$ & Nitrogen, Nitrate & 1 & 7.1 & & \\
\hline $\mathrm{mg} / \mathrm{l}$ & Oil \& Grease & $<0.5$ & 0.5 & & \\
\hline unit & $\mathrm{pH}$ & 6.8 & 6.9 & 7 & 7.1 \\
\hline $\mathrm{mg} / \mathrm{I}$ & $\begin{array}{l}\text { Petroleum } \\
\text { Hydrocarbons, Total } \\
\end{array}$ & & & $<0.50$ & $<0.50$ \\
\hline $\mathrm{mg} / 1$ & Phenols, Total & & & $<0.10$ & $<0.10$ \\
\hline$m i g / 1 P$ & Phosphate, Total & $<0.1$ & $<0.1$ & & \\
\hline $\mathrm{mg} / \mathrm{l} P$ & Phosphate, Ortho & $<0.1$ & $<0.1$ & & \\
\hline $\mathrm{mg} / \mathrm{I}$ & Solids-Dissolved & 113 & 103 & 236 & 229 \\
\hline $\mathrm{mg} / \mathrm{l}$ & \begin{tabular}{|l} 
Solids - Suspended \\
\end{tabular} & 9 & $=12$ & 22 & 26 \\
\hline $\mathrm{mg} / \mathrm{sO} \mathrm{S}_{4}$ & \begin{tabular}{|l} 
Sulfate \\
\end{tabular} & 6040 & $5 \overline{460}$ & & \\
\hline Dag $C$ & \begin{tabular}{|l} 
Temperature \\
\end{tabular} & 8 & 9 & & \\
\hline NTU & Turbidity & 4 & 4.2 & & \\
\hline $\mathrm{mg} / \mathrm{Zn}$ & Zinc & 0.02 & $<0.02$ & & \\
\hline & Clarity & Clear & Clear & & \\
\hline
\end{tabular}




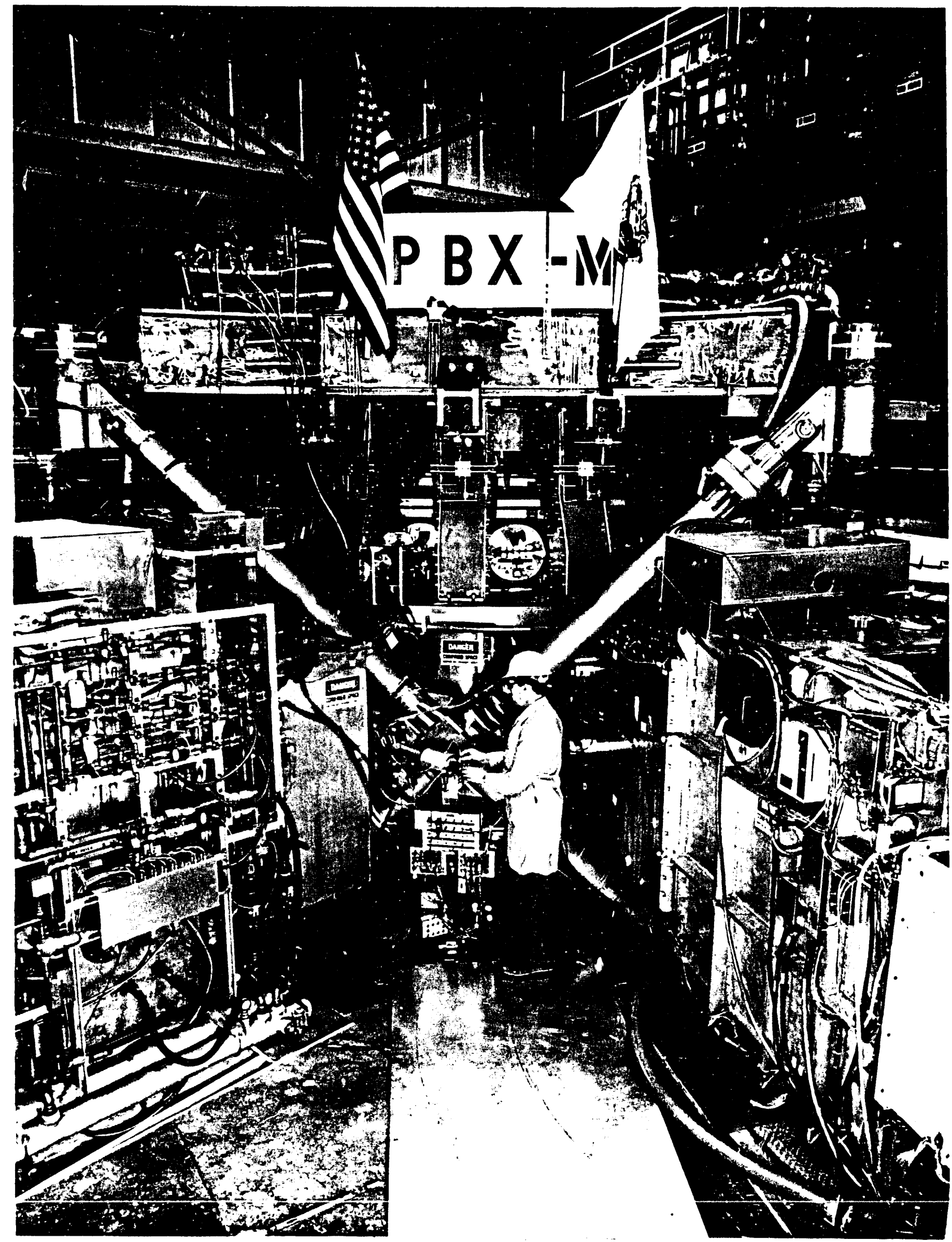

Figure 1. The Princeton Beta Experiment - Modified (PBX-M) 


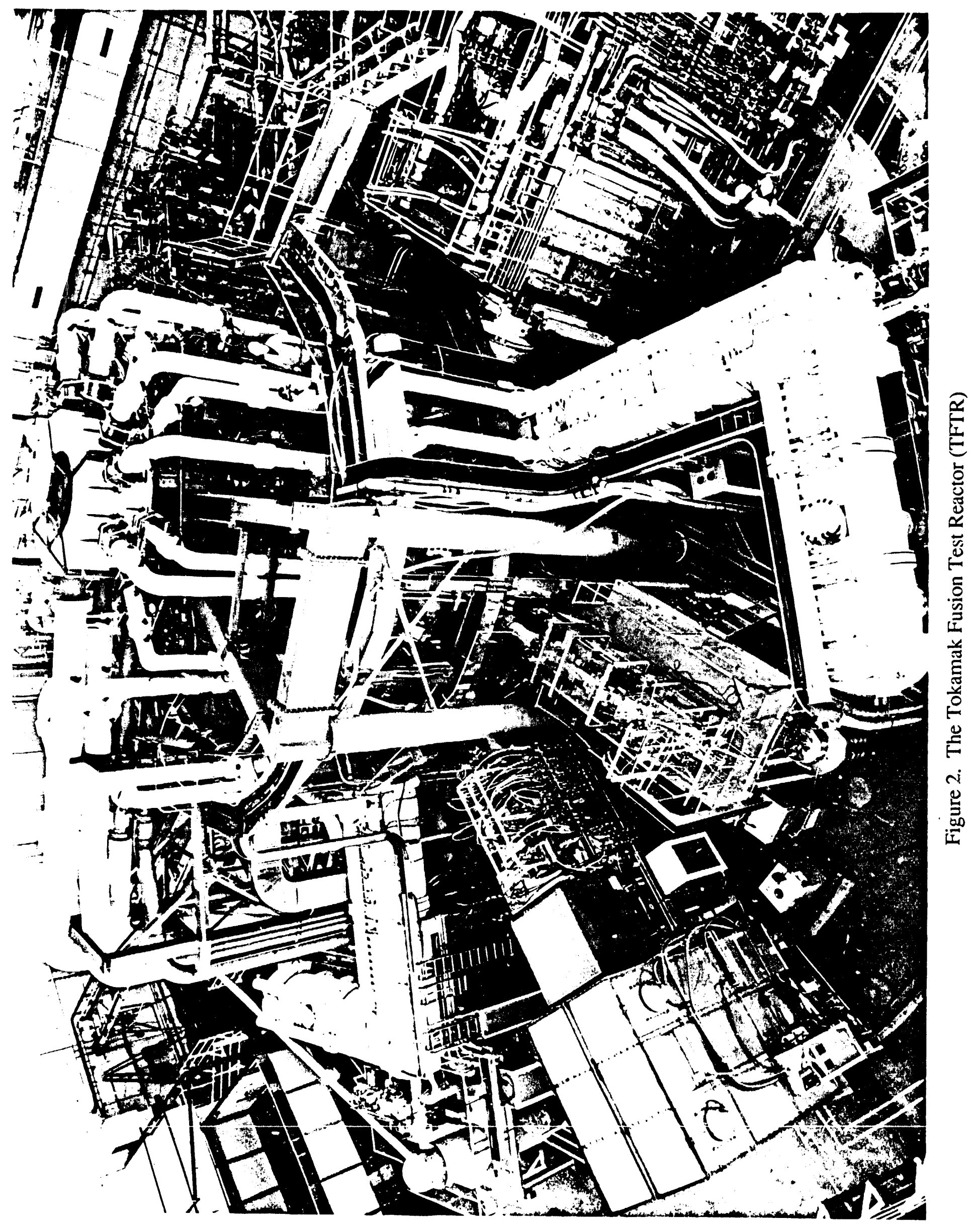




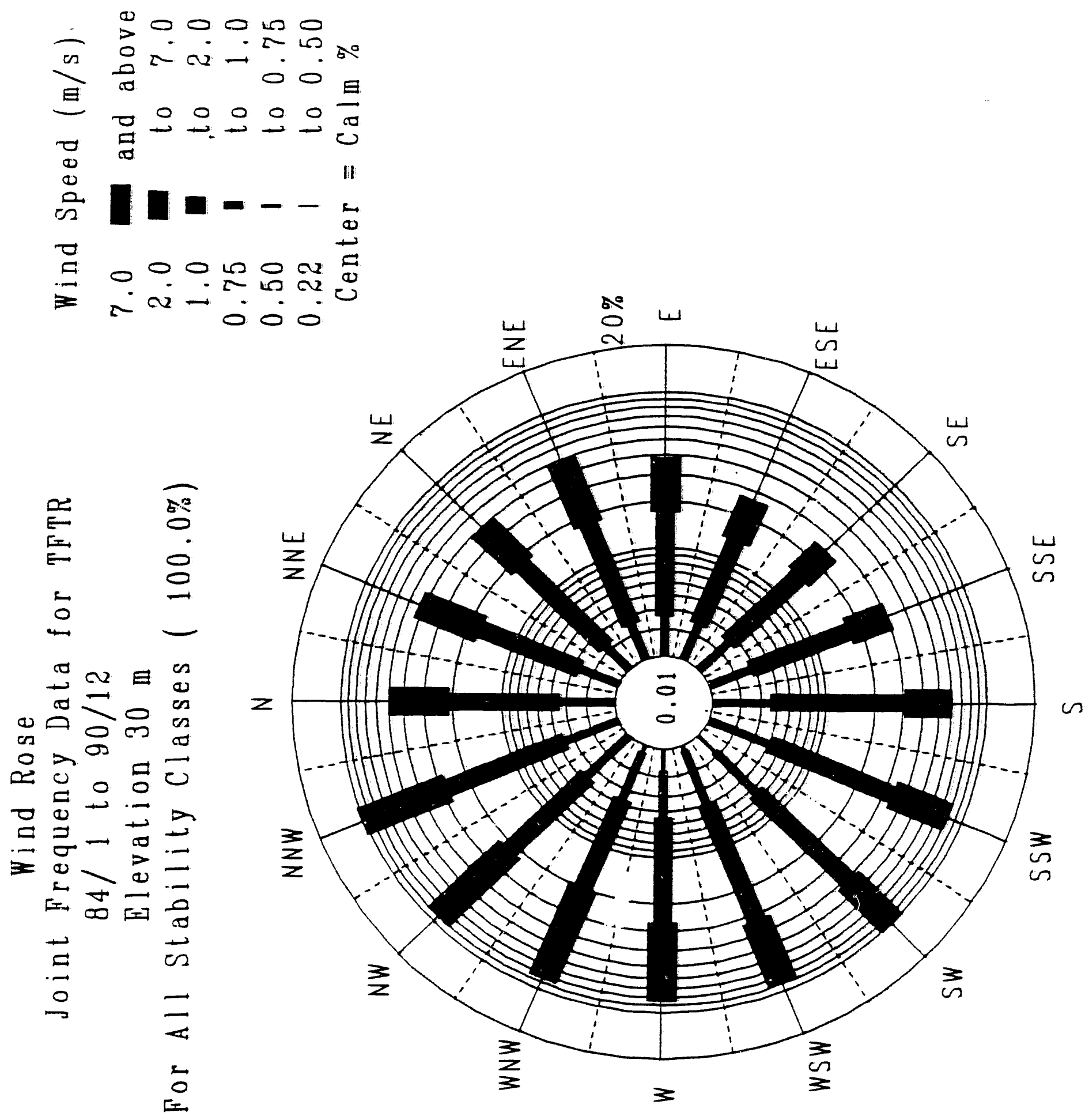

Eigure 3. Wind Rose at $30 \mathrm{~m}$. 


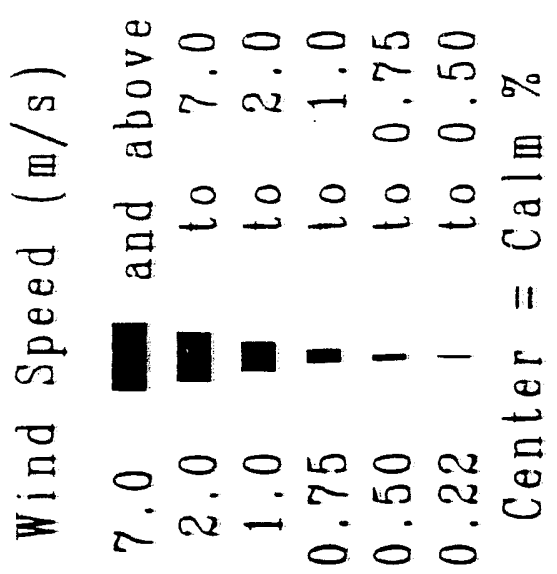

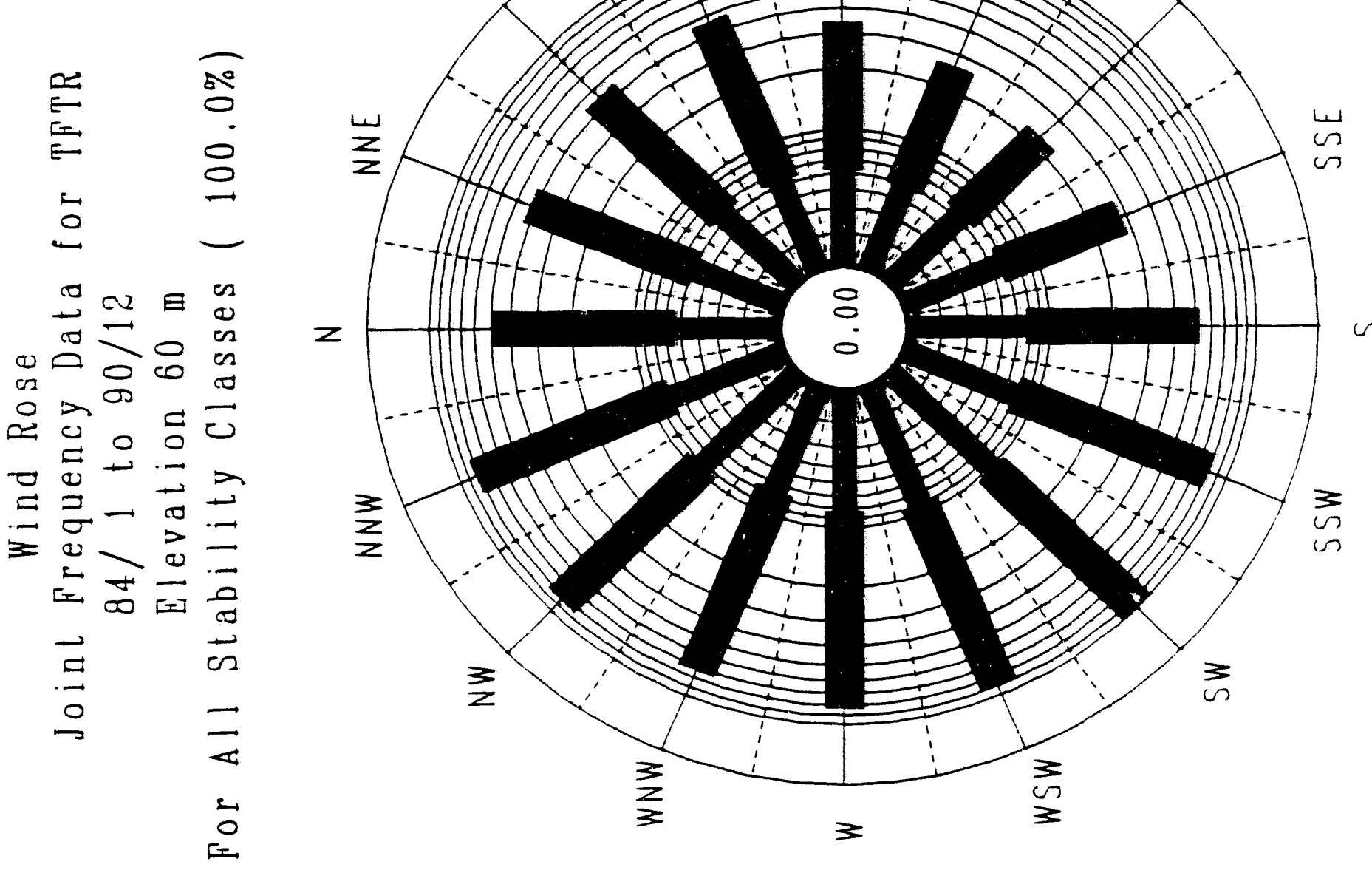

Eigure 4. Wind Rose at $60 \mathrm{~m}$. 


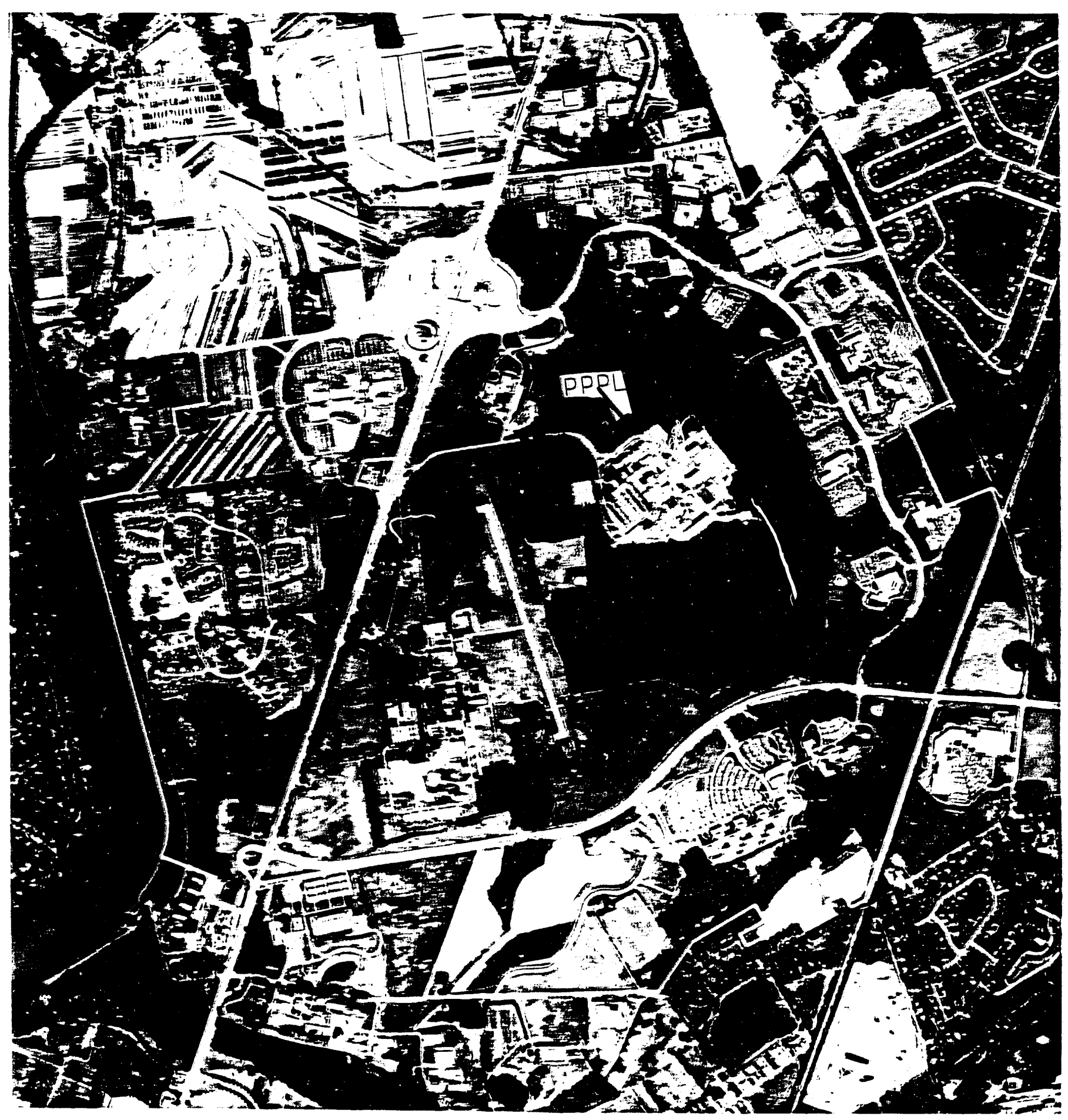

Figure 5. Aerial View of the Forrestal Campus 


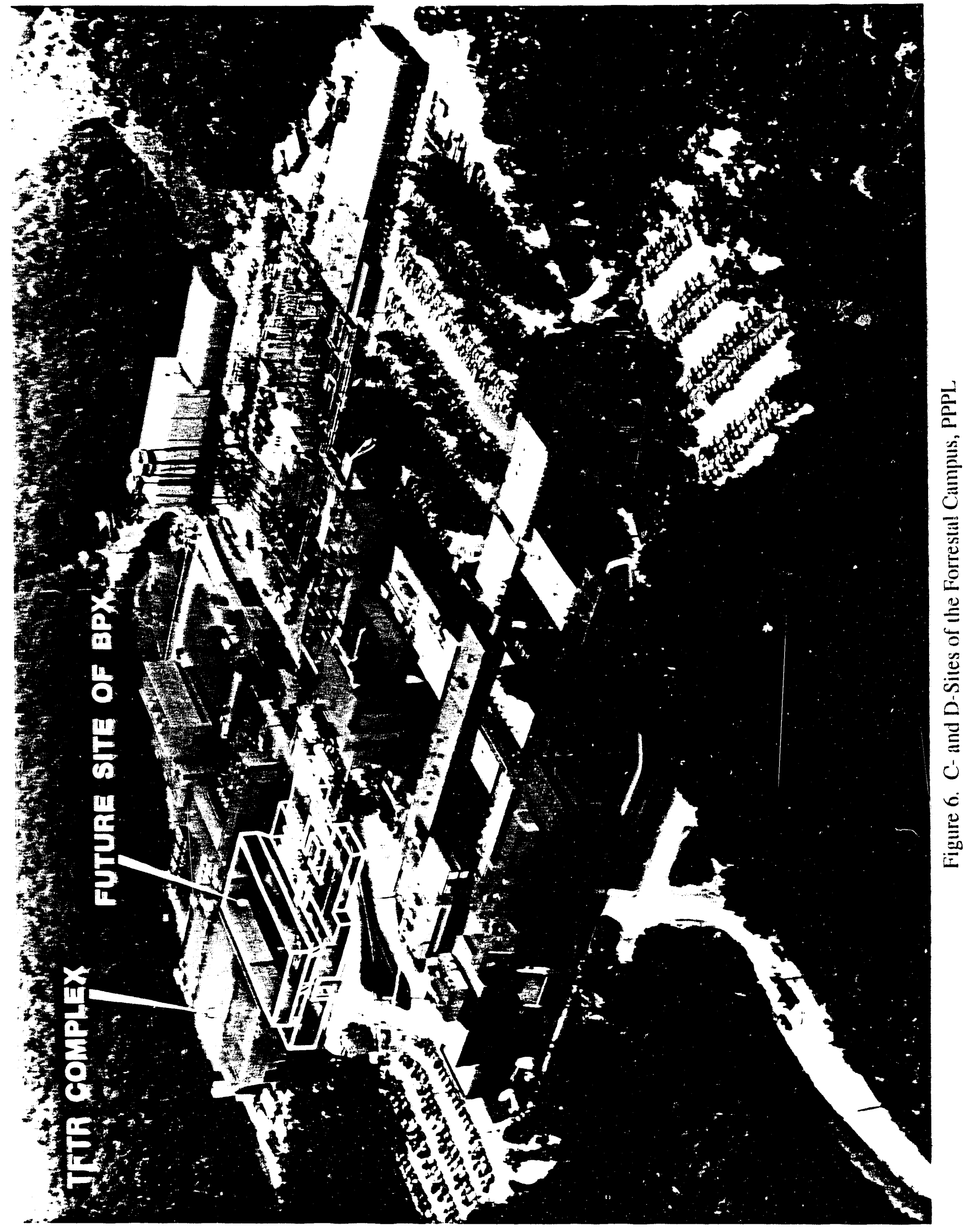




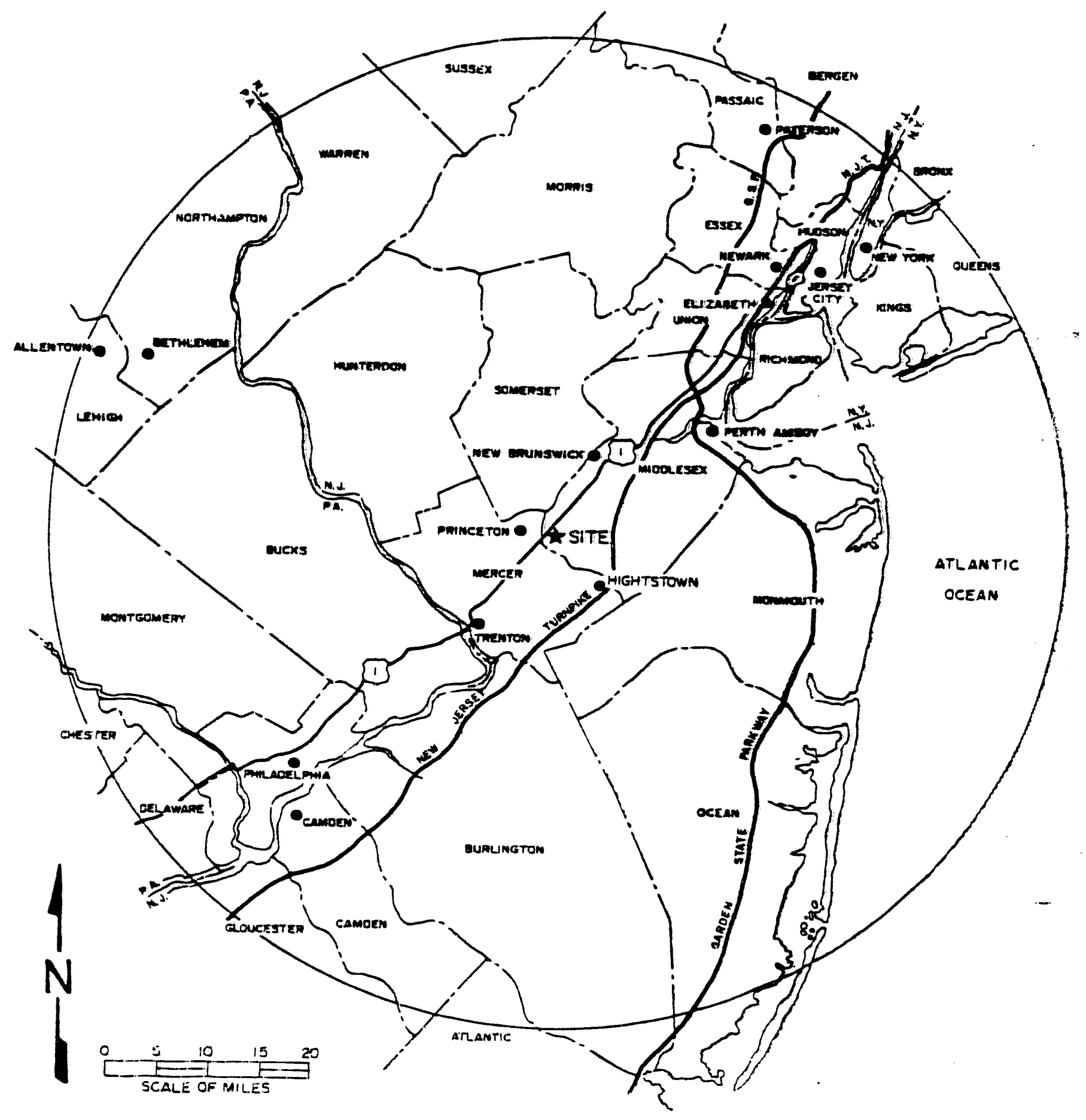

Figure $7.80 \mathrm{~km}$ (50-mile) Radius of PPPL Site 


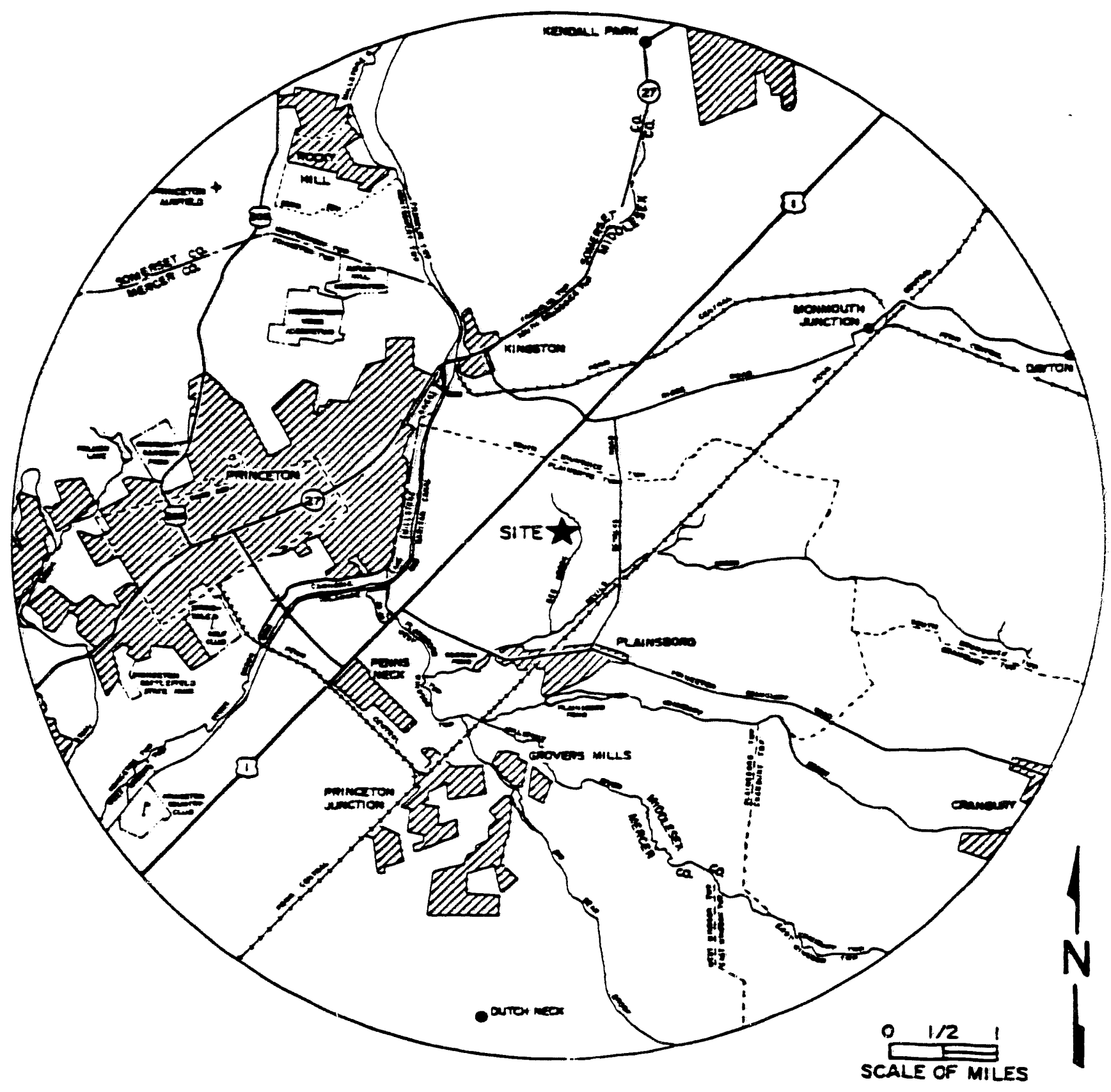

Figure 8. Immediate Site Vicinity (5-Mile Radius) 


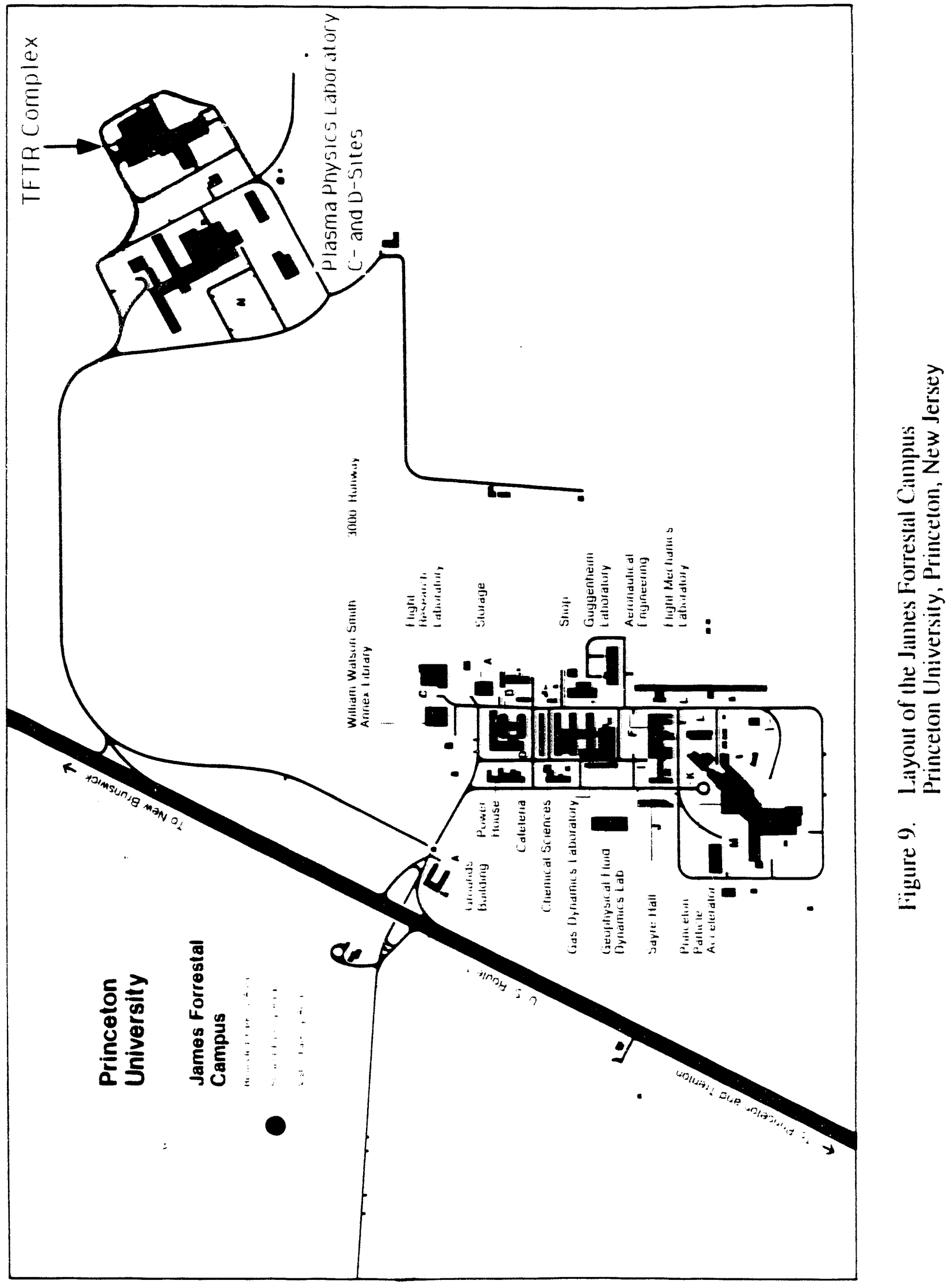




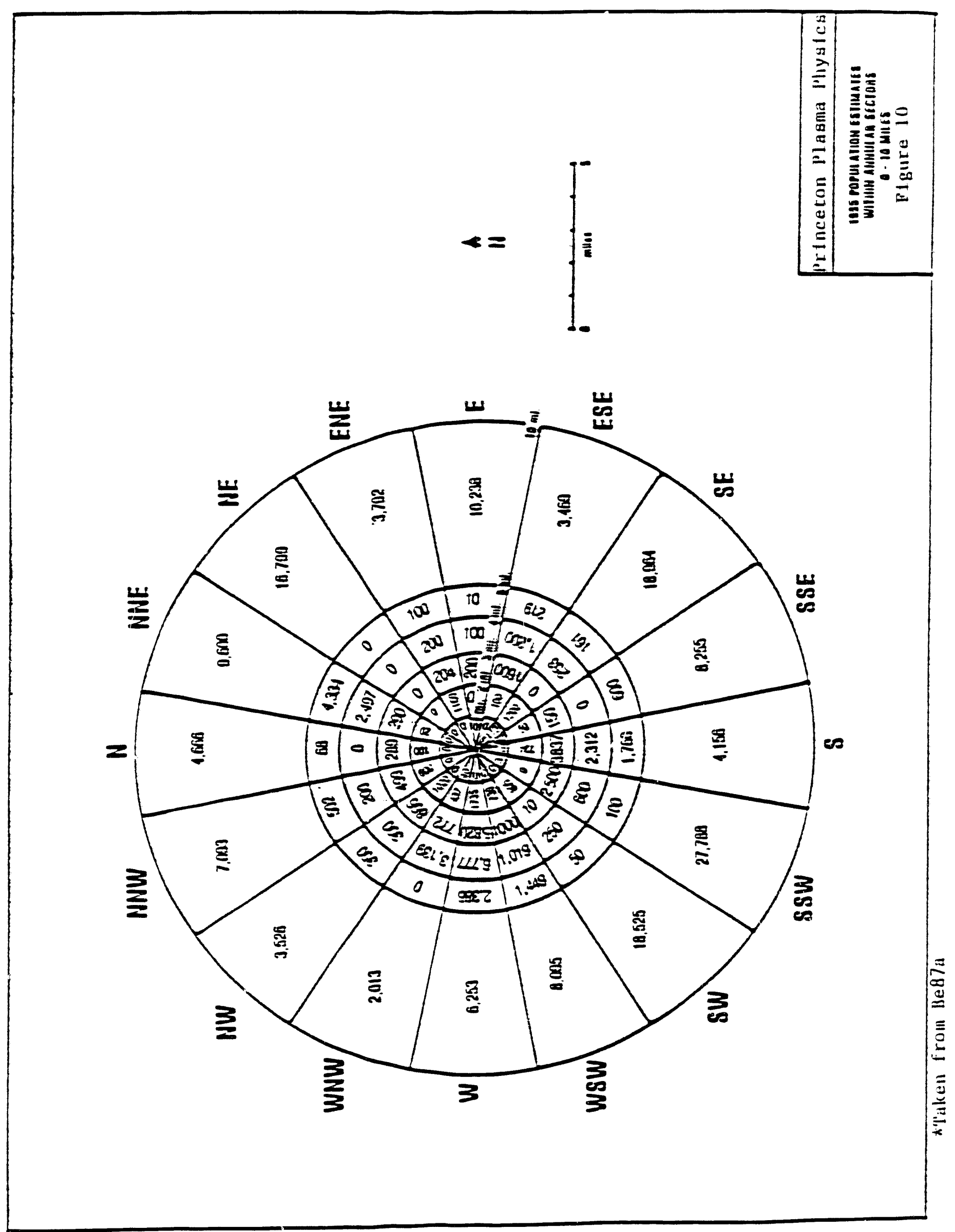




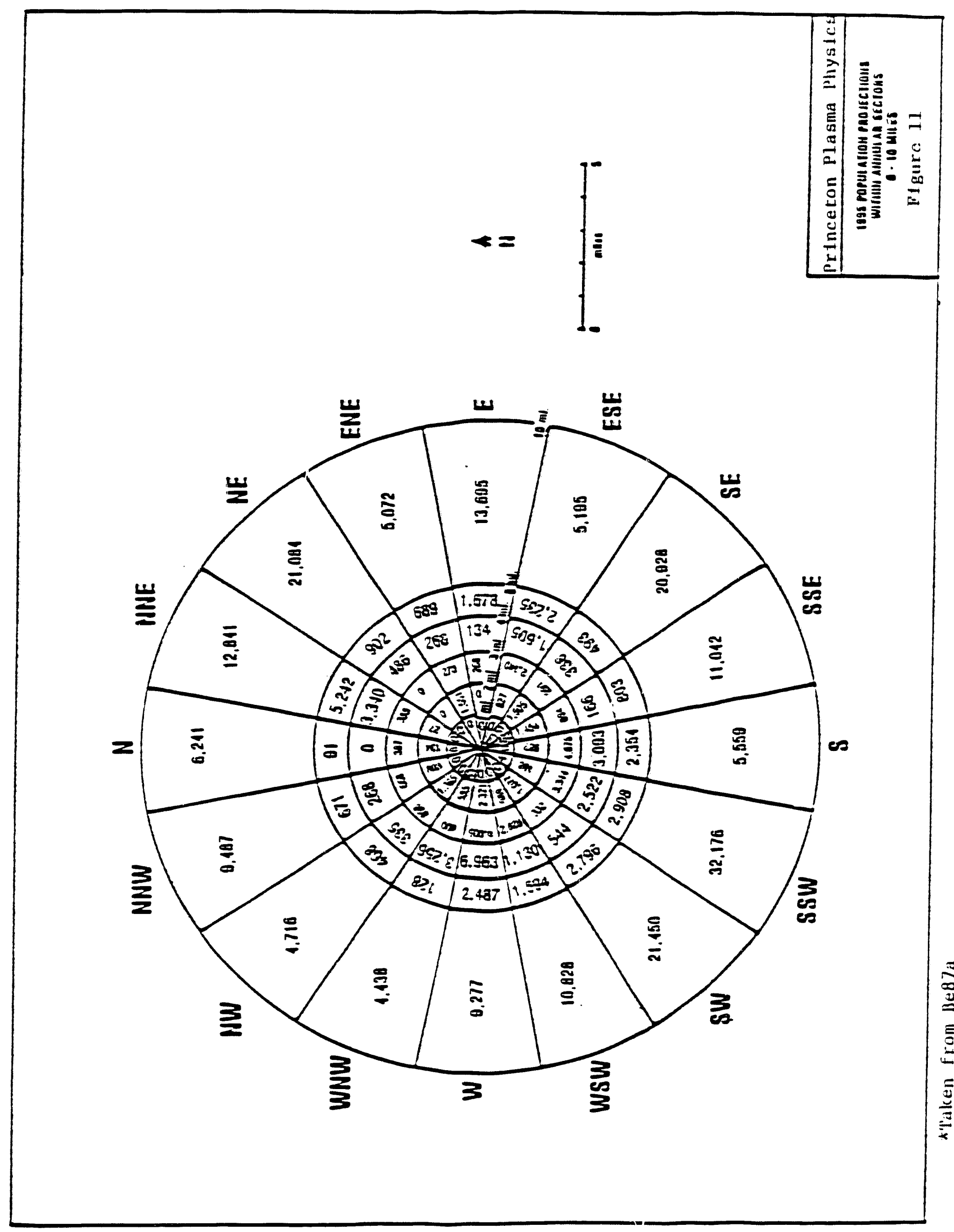




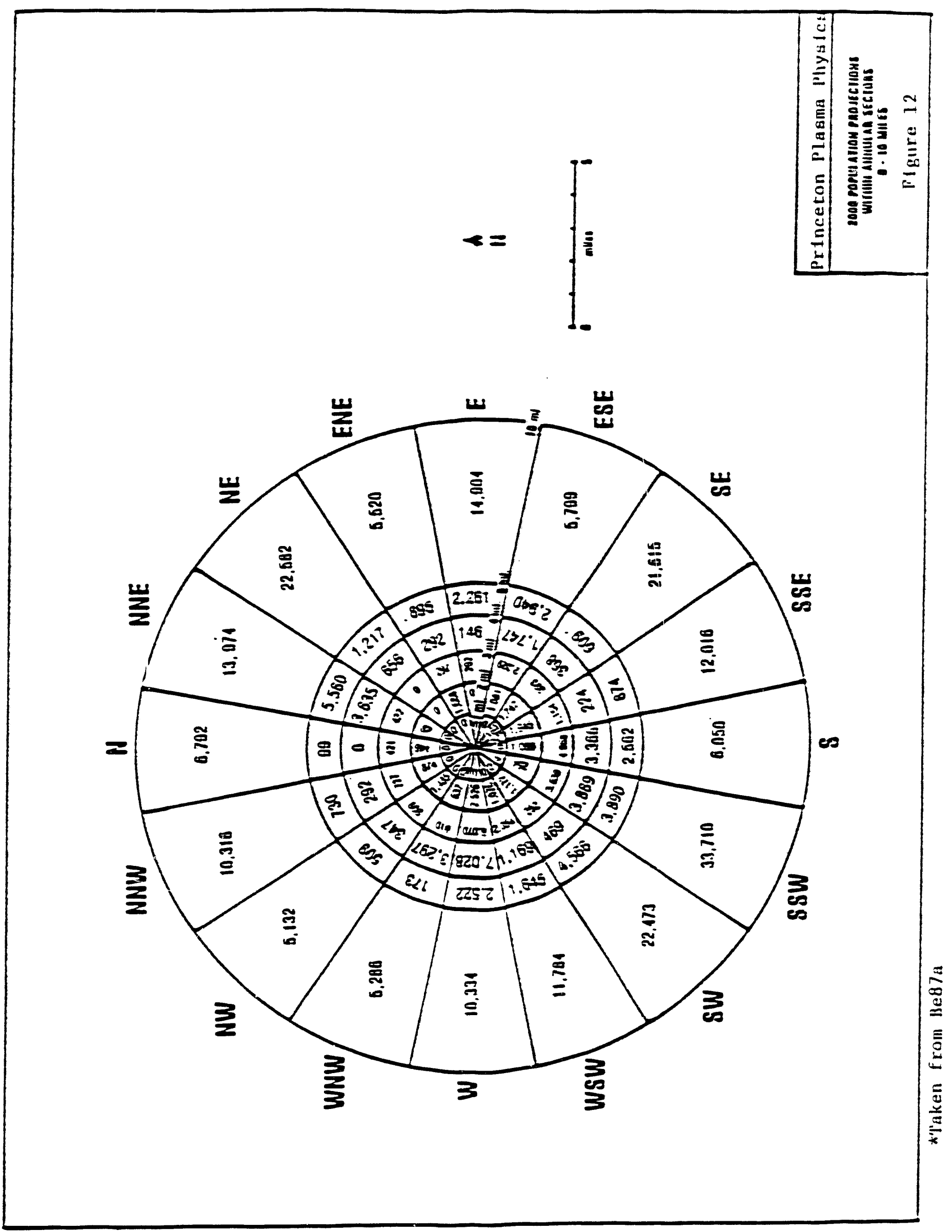




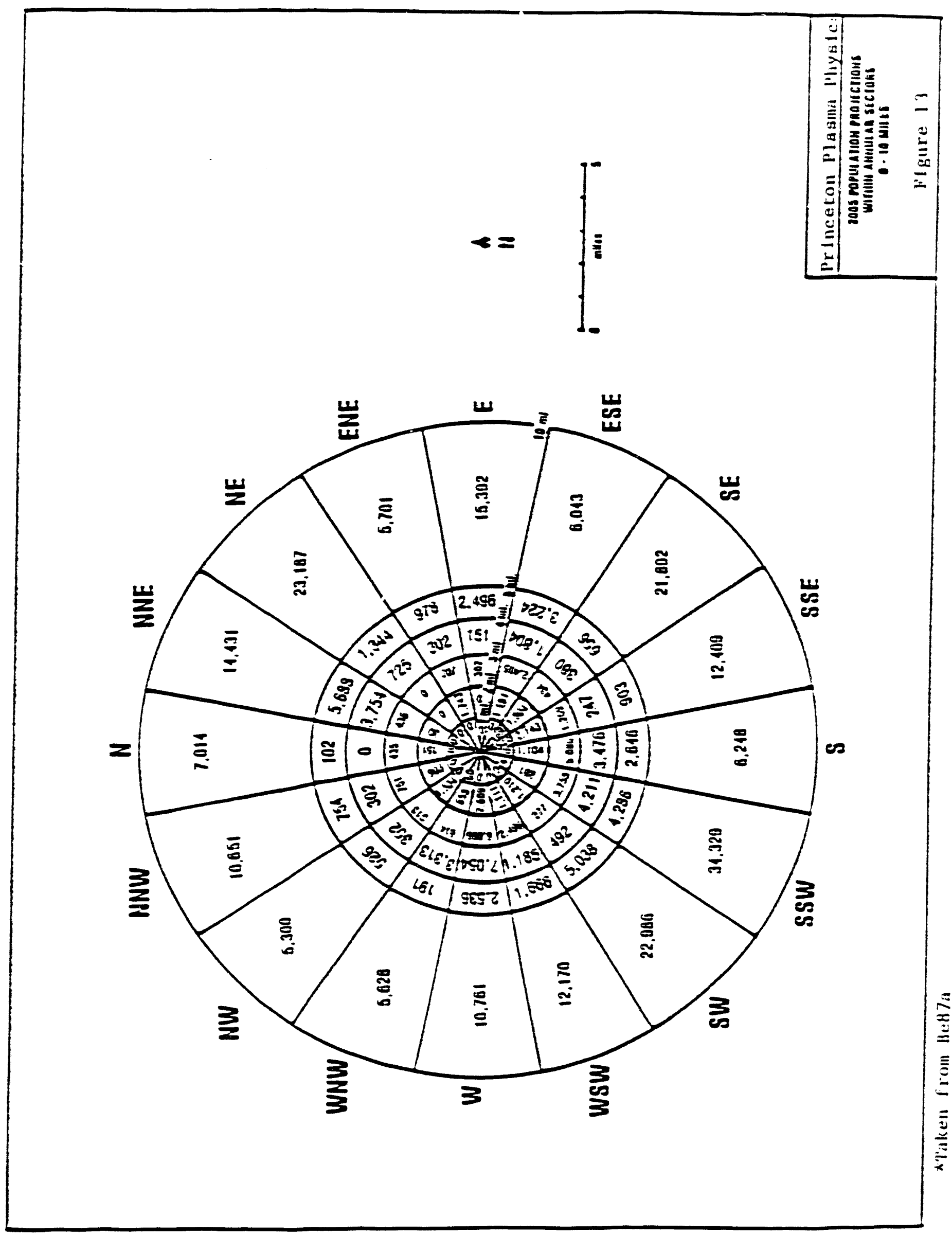




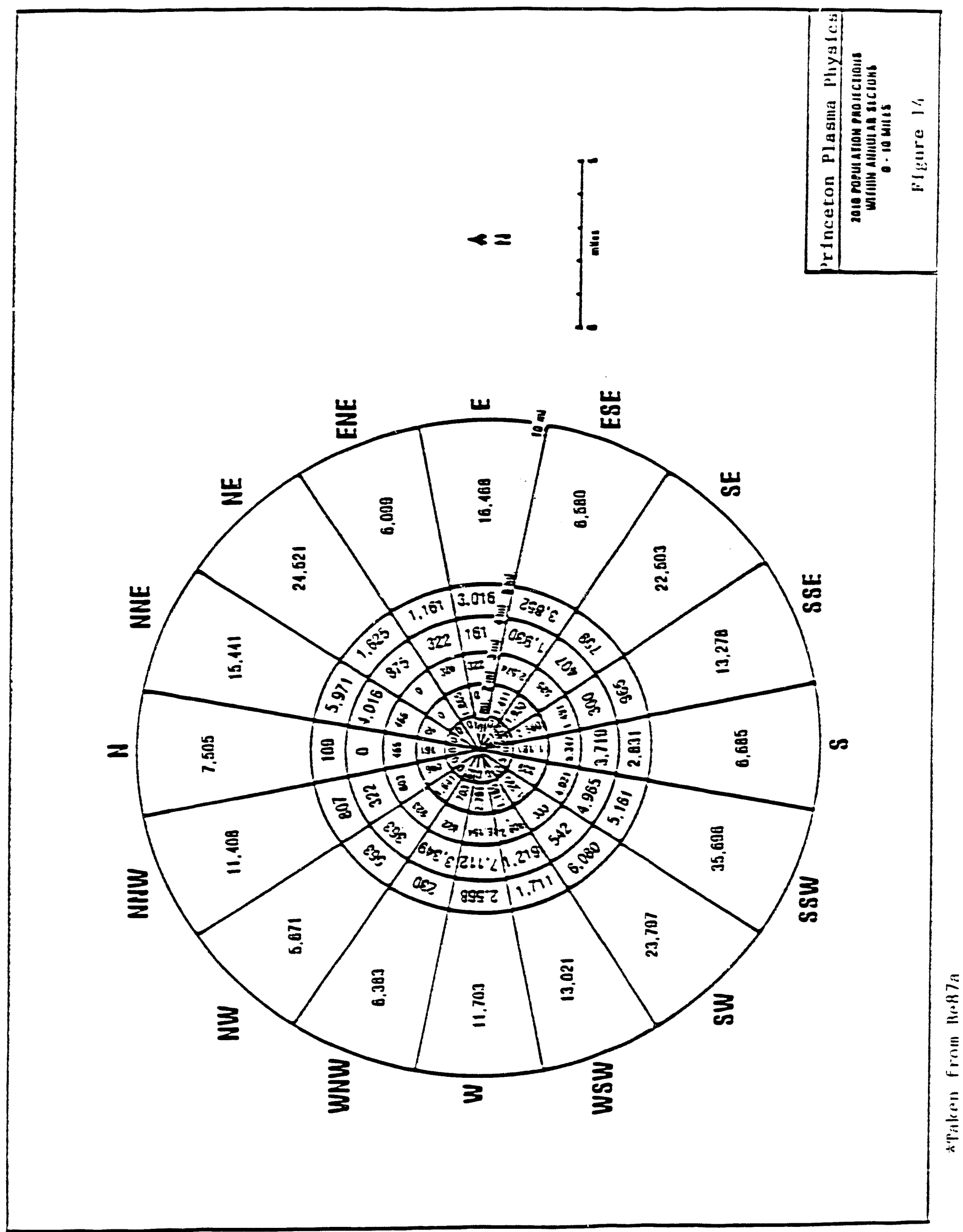




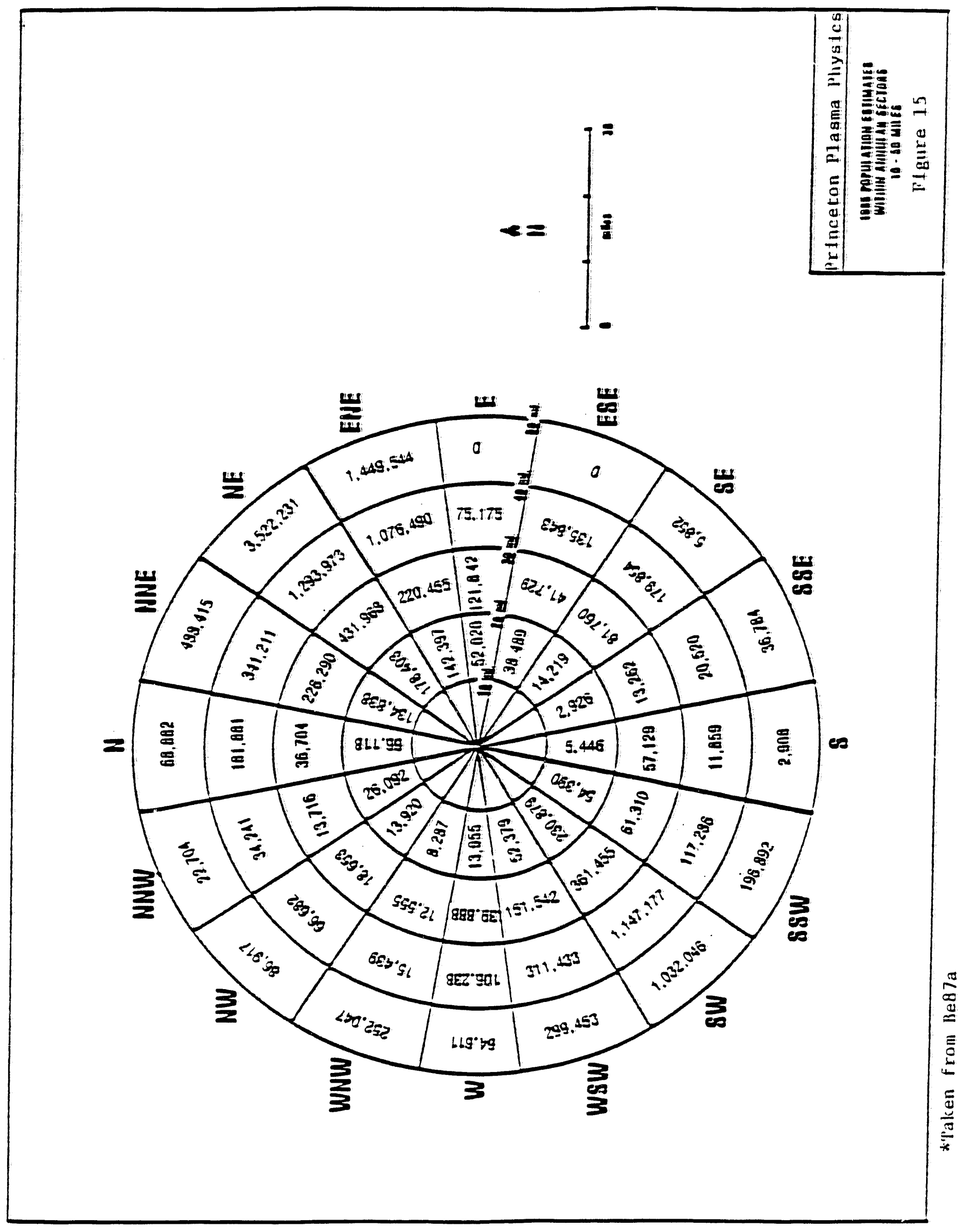




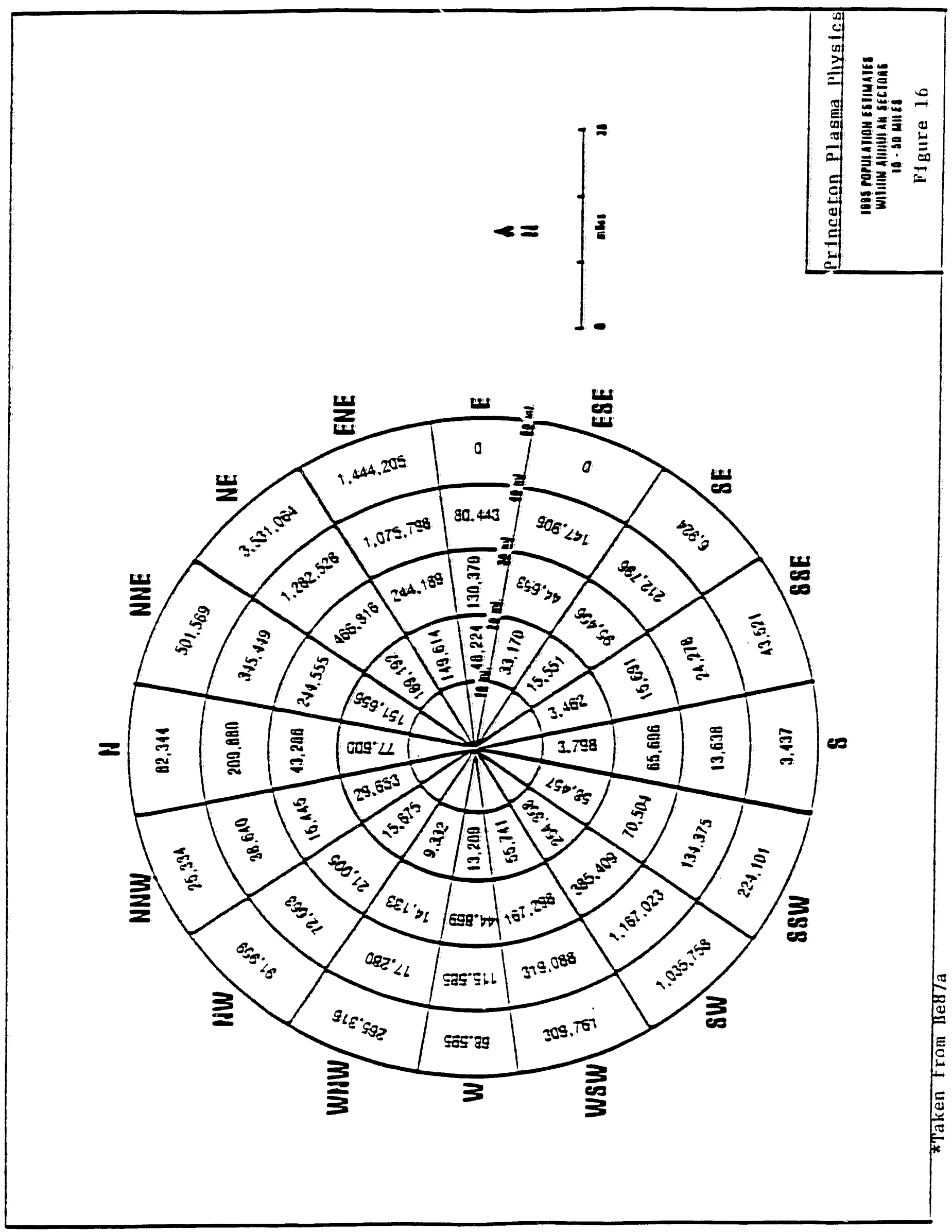




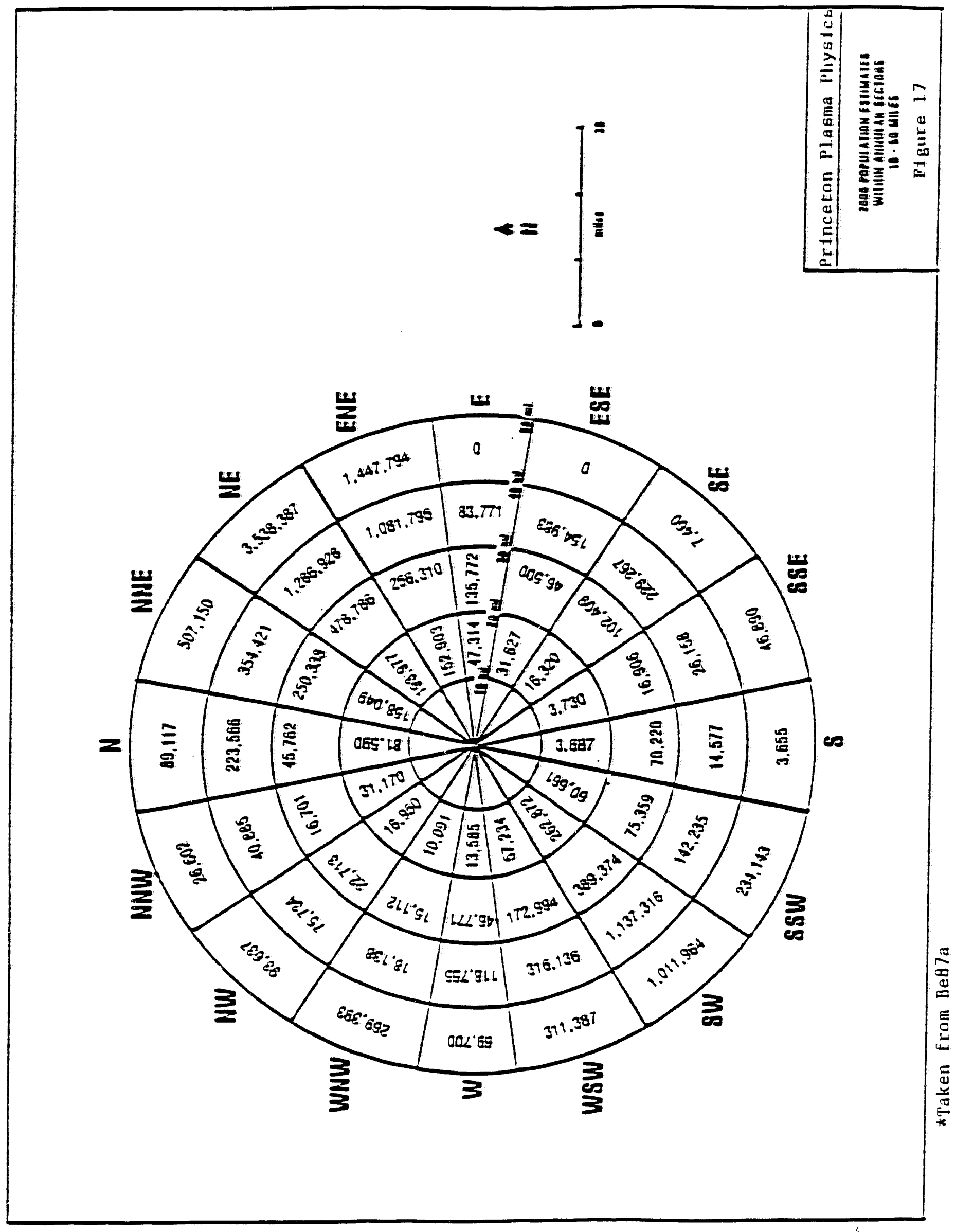




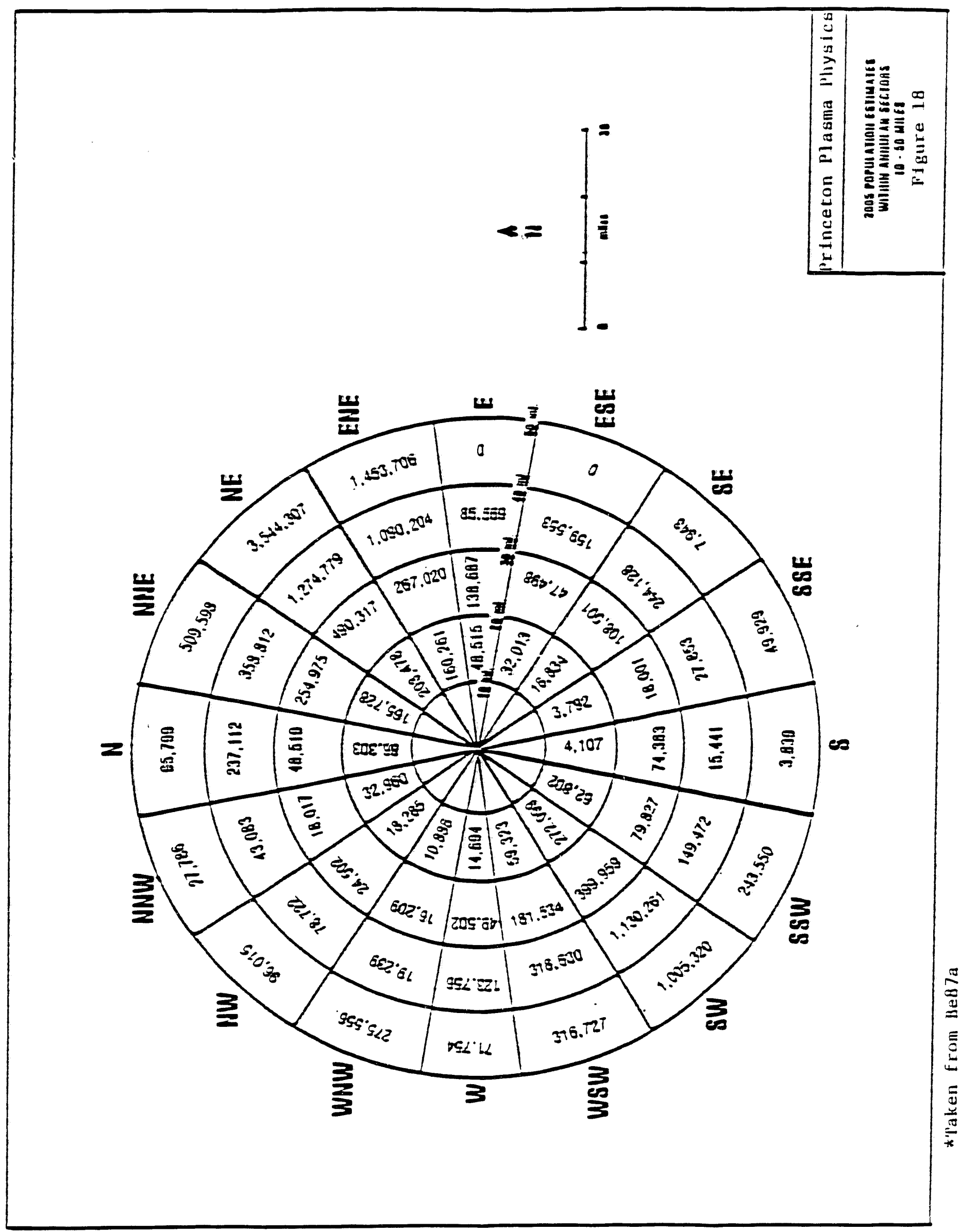




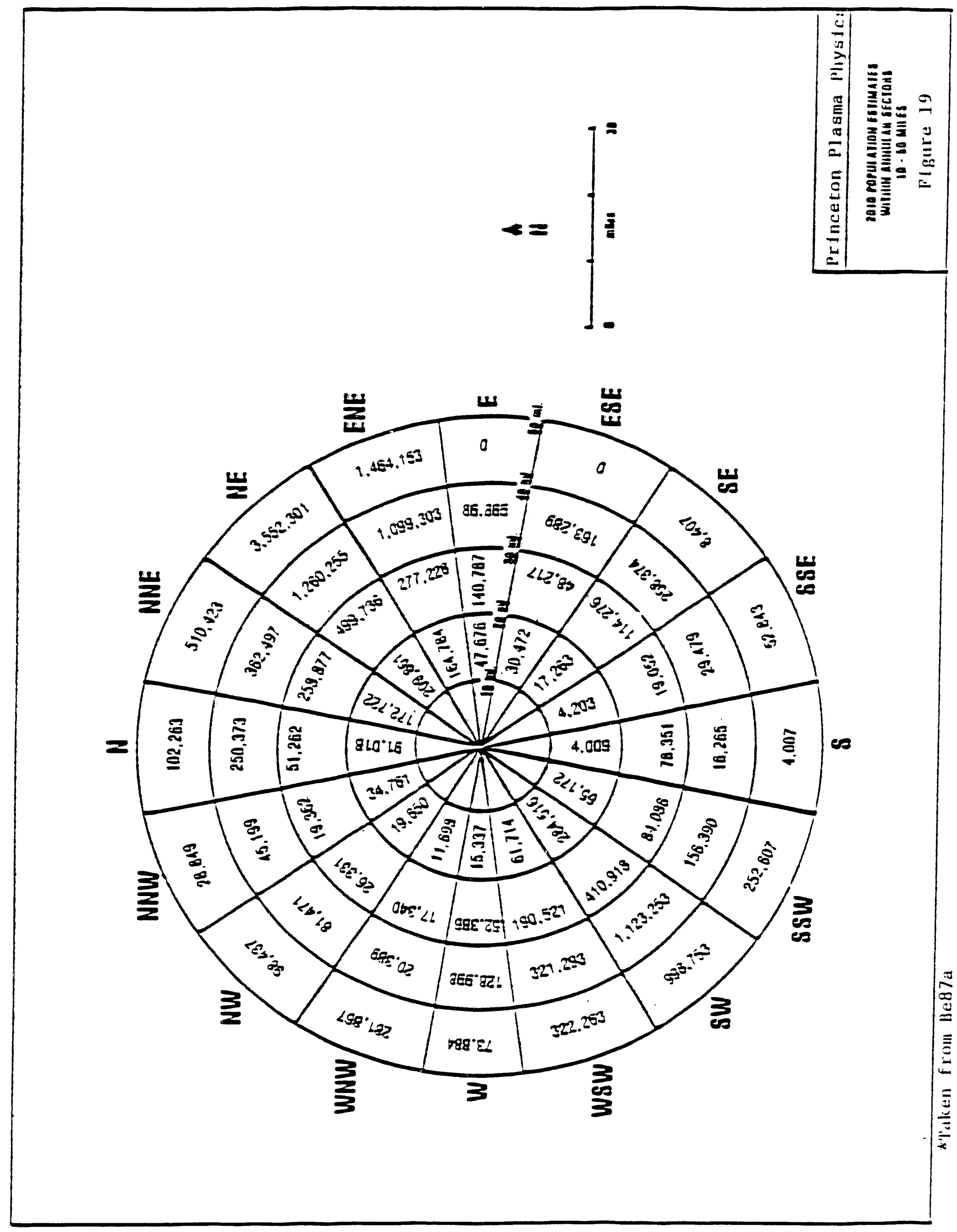




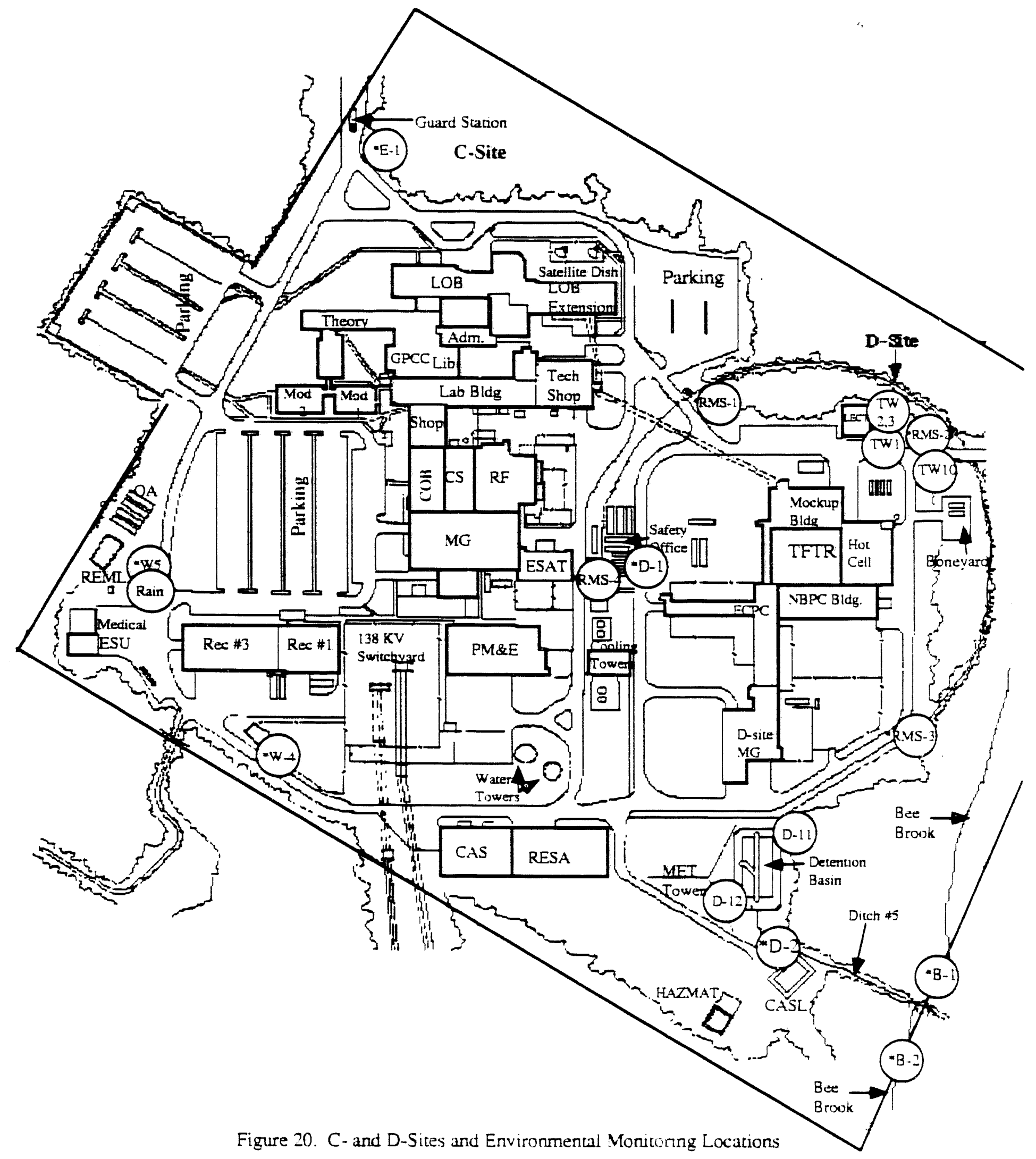




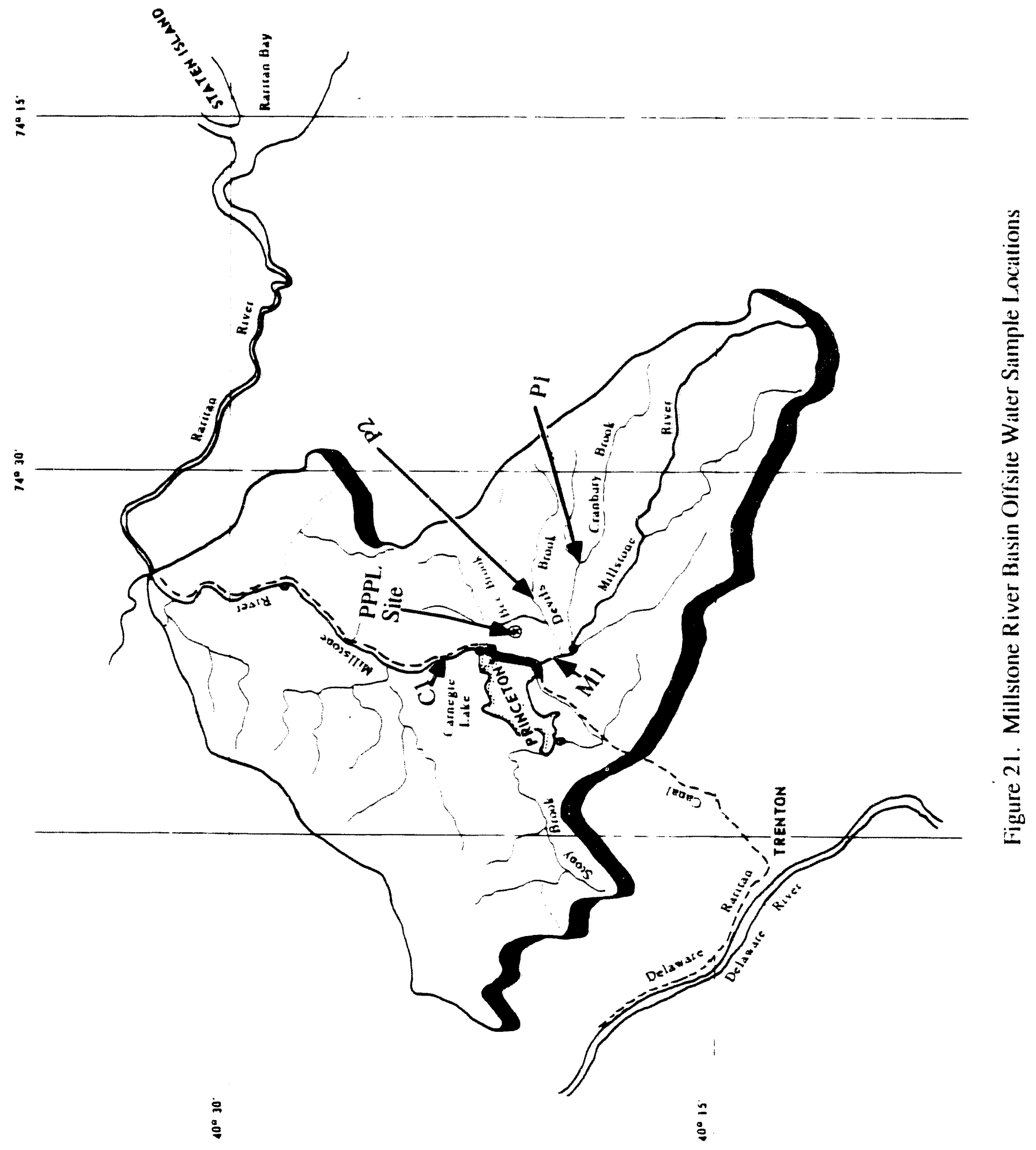

- (2) 


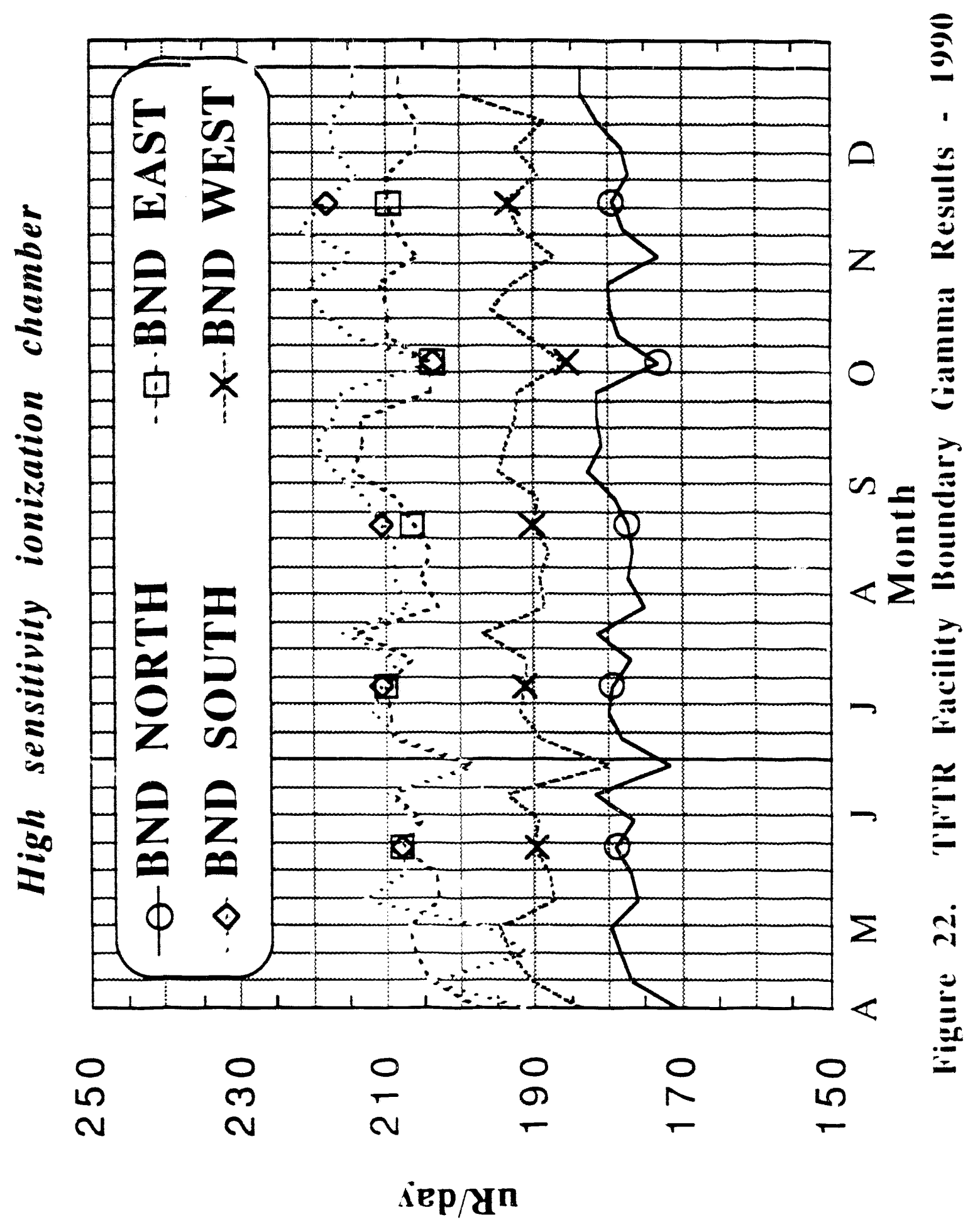




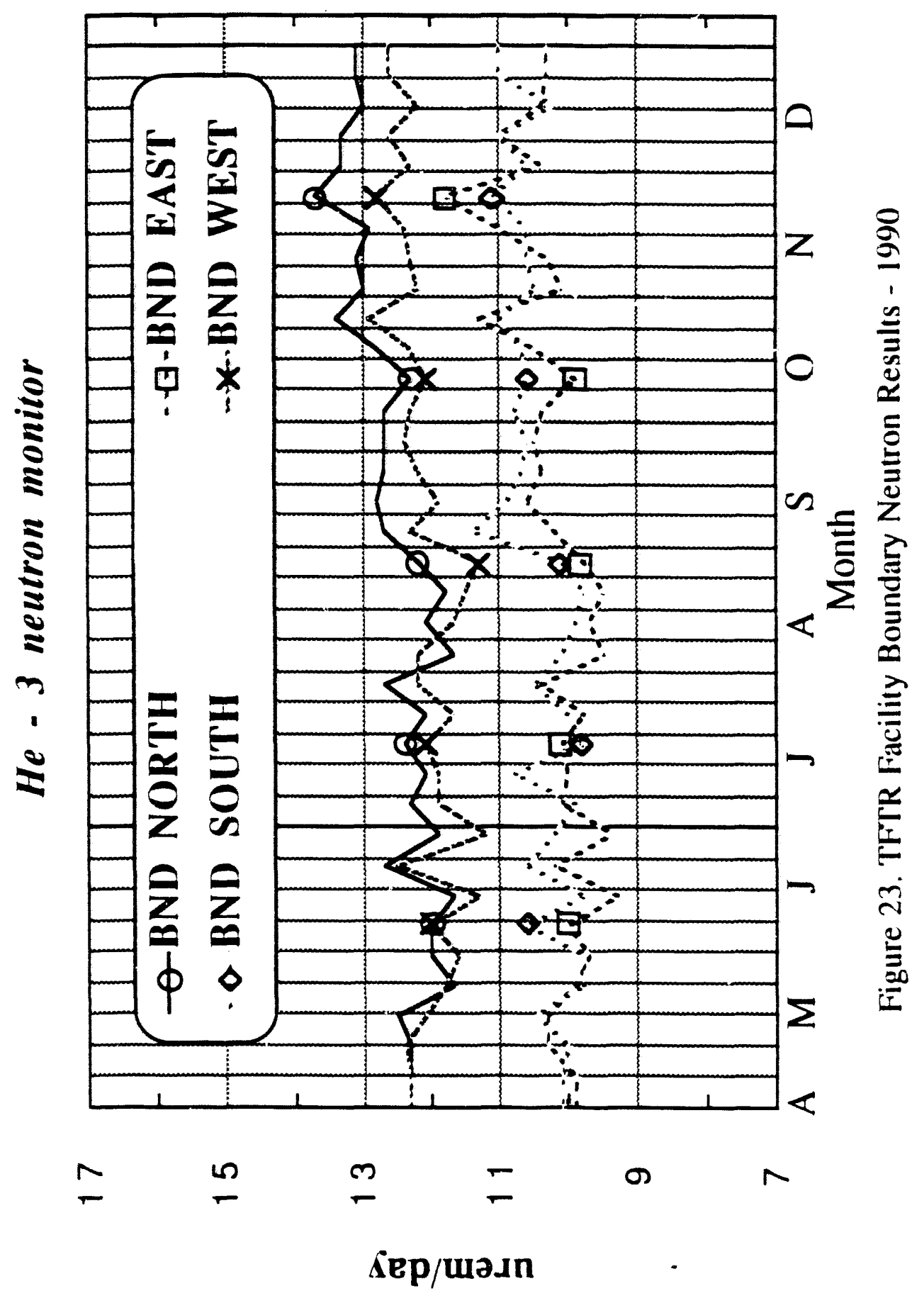




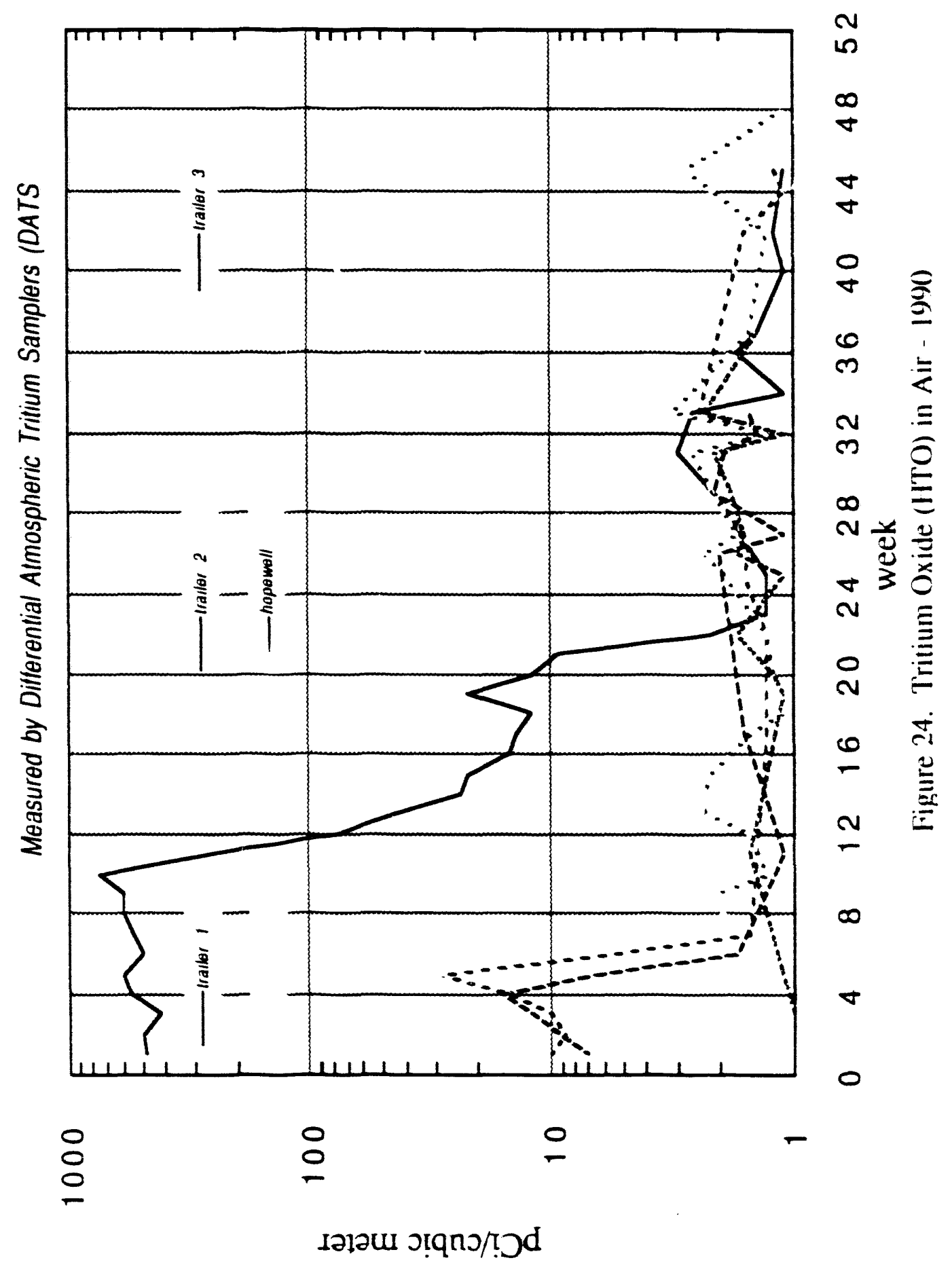




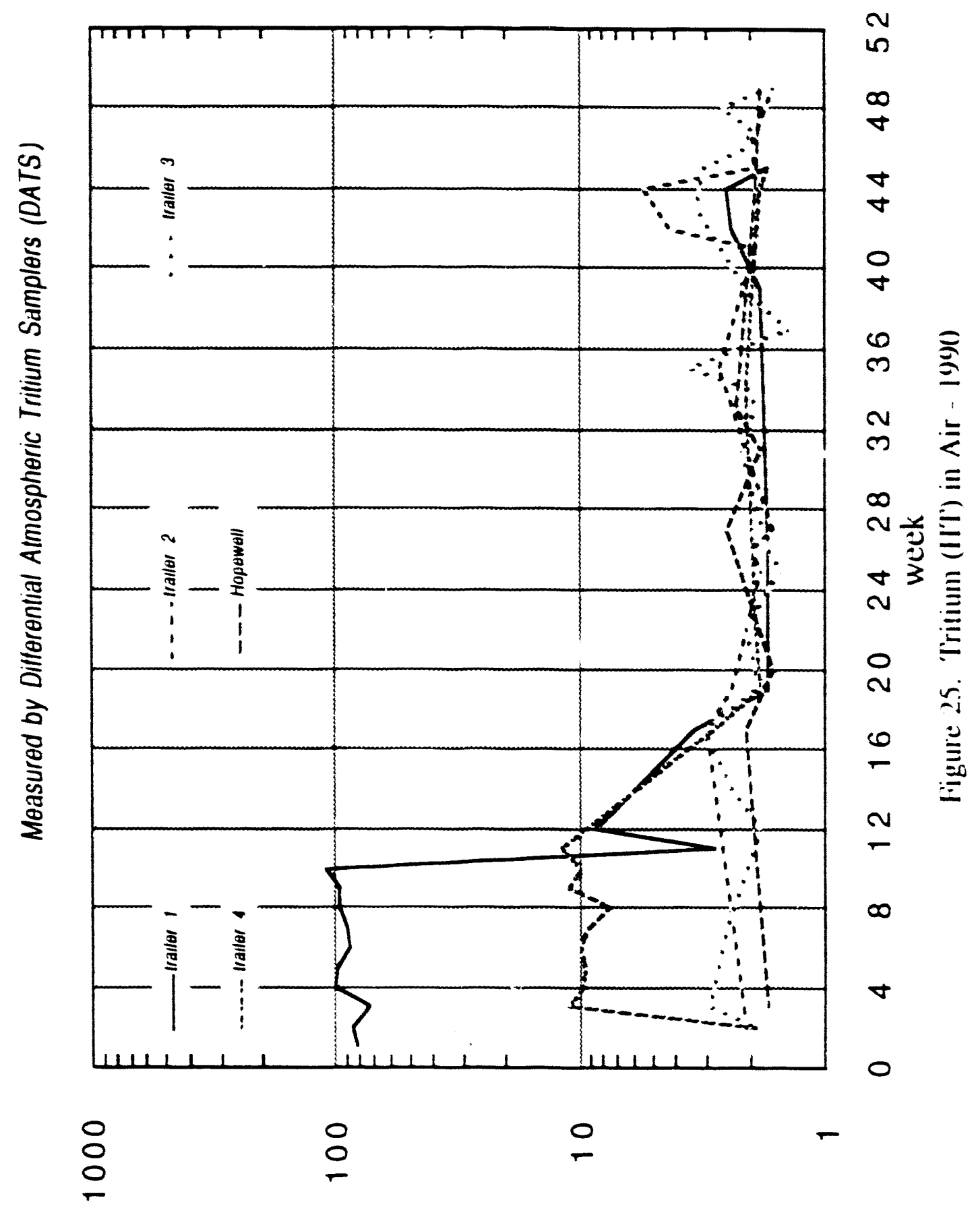

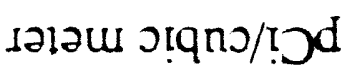




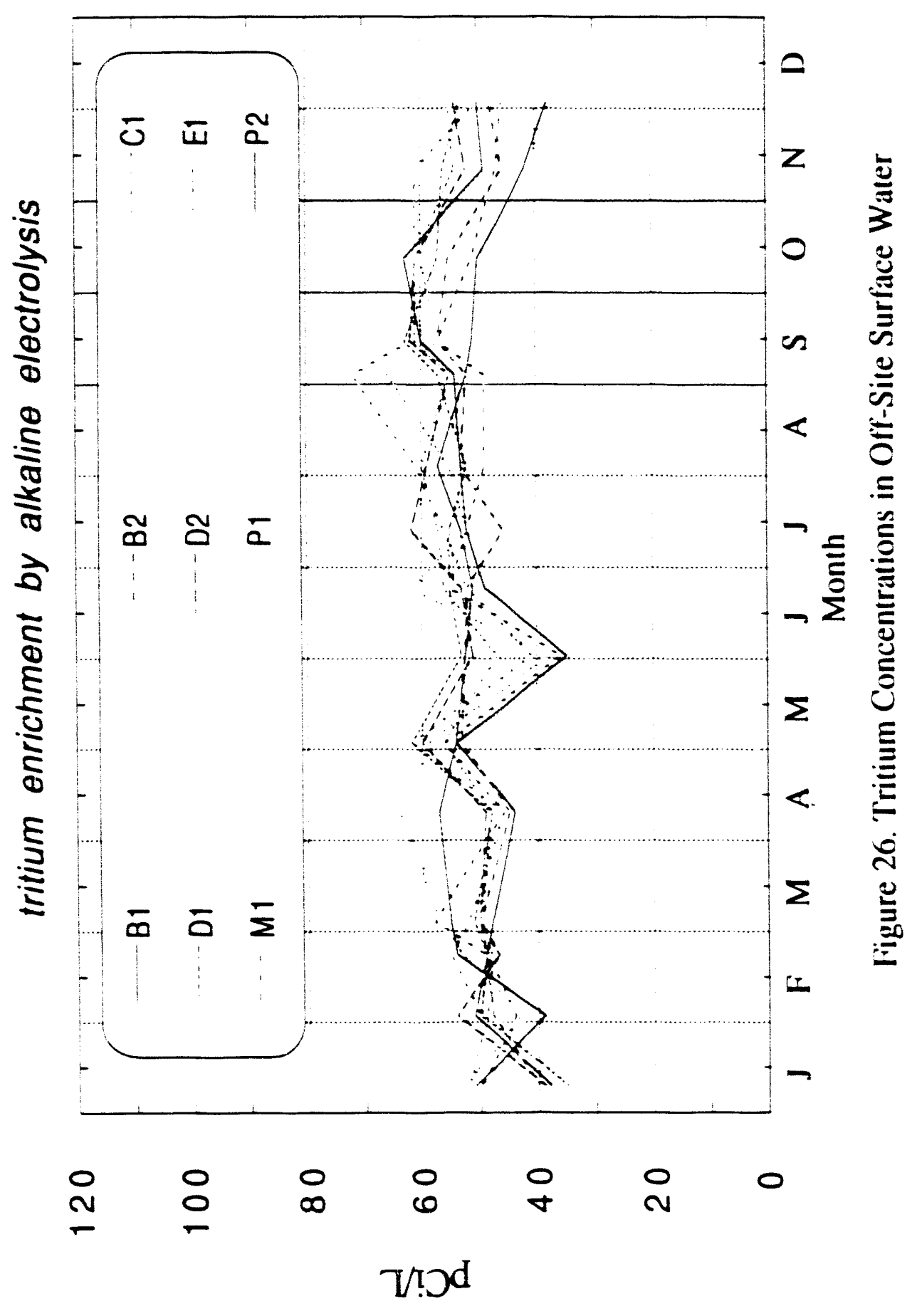




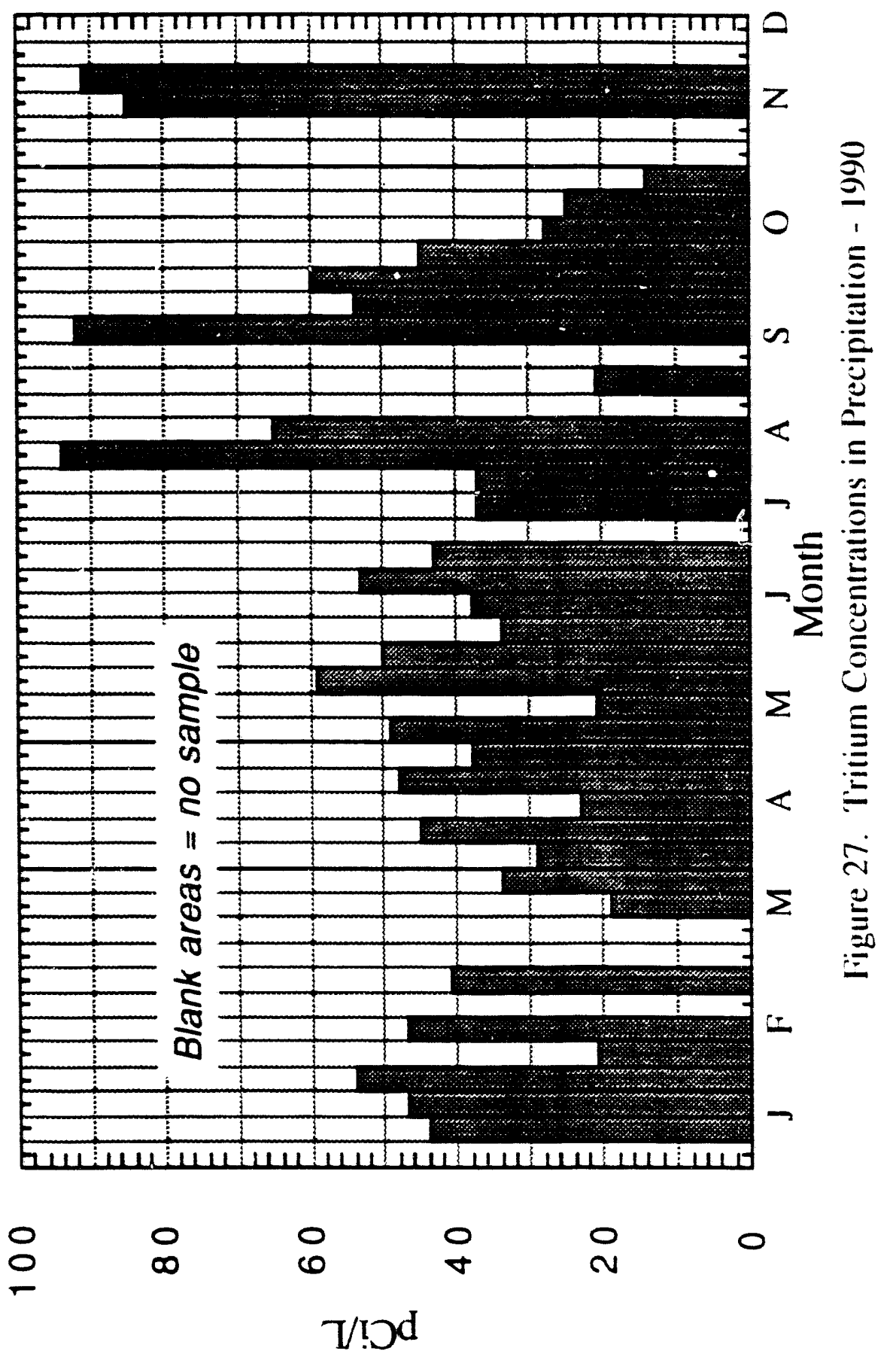




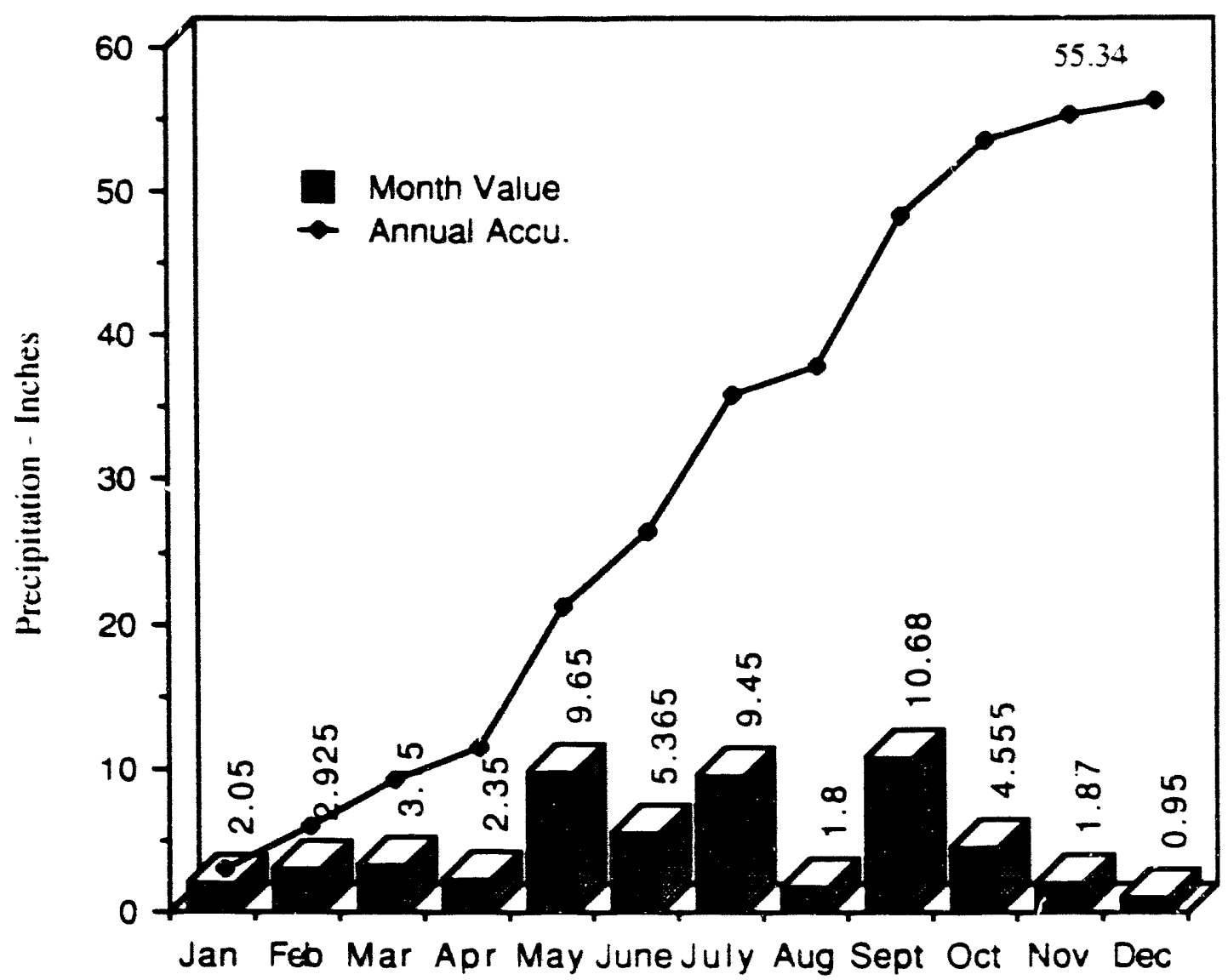

Month - 1989

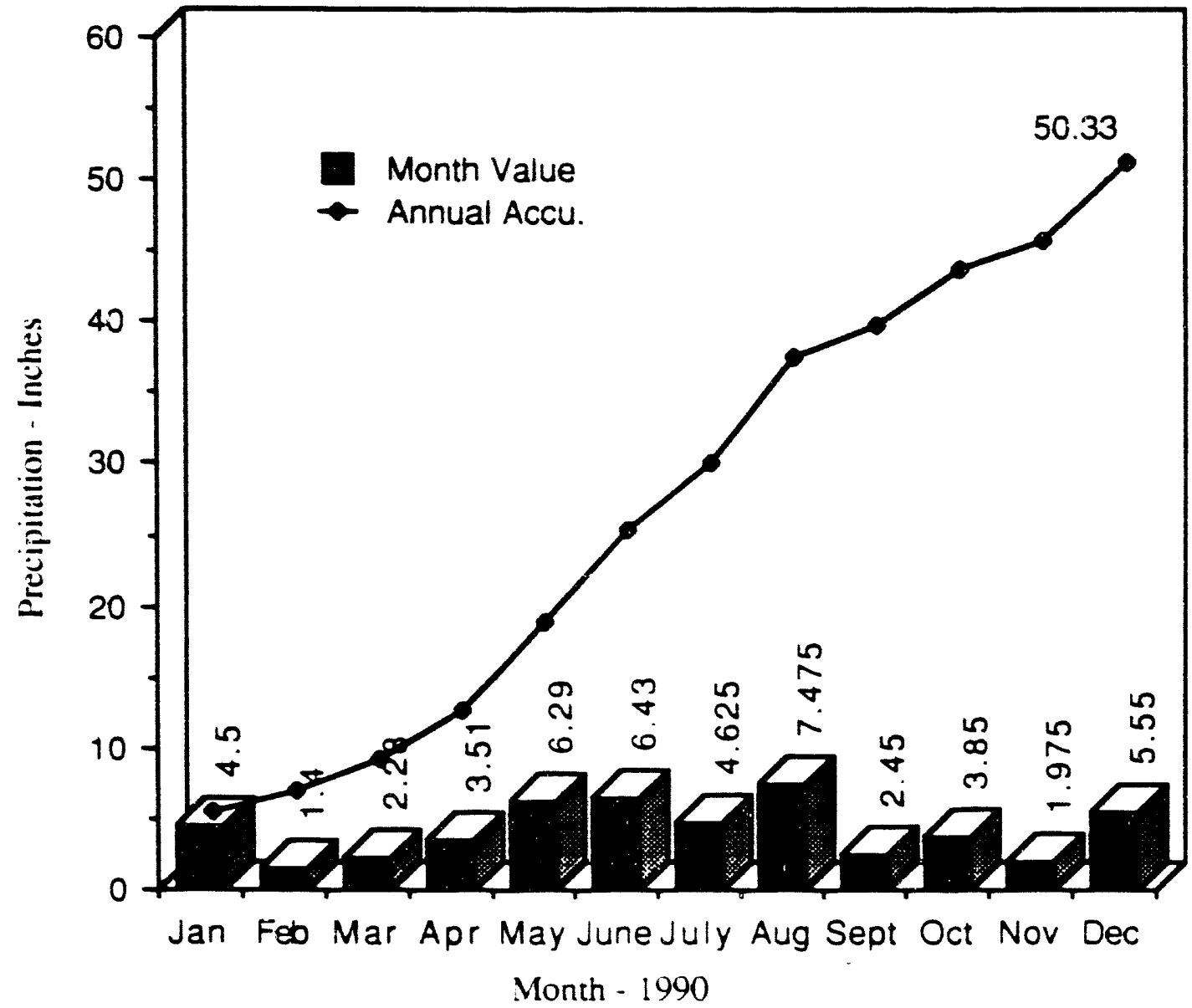

Figure 28. Precipitation at PPPL 


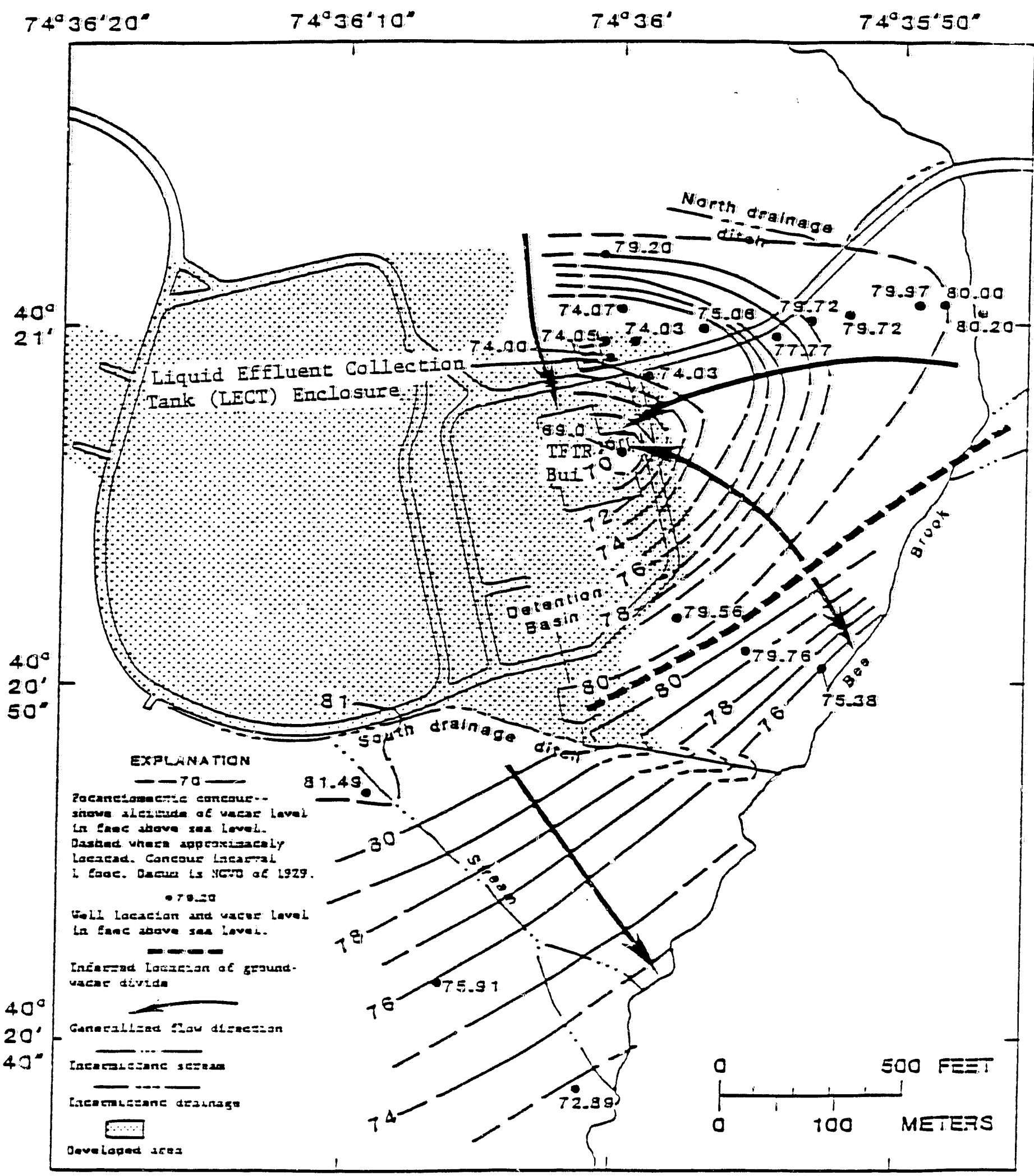

Base mag modilled from Air-Tgraphy (198z)

Figure 29. Potentiometzic surzice of the bedrock aquiEer, October 30, I\$86 (Taken from Le87) 


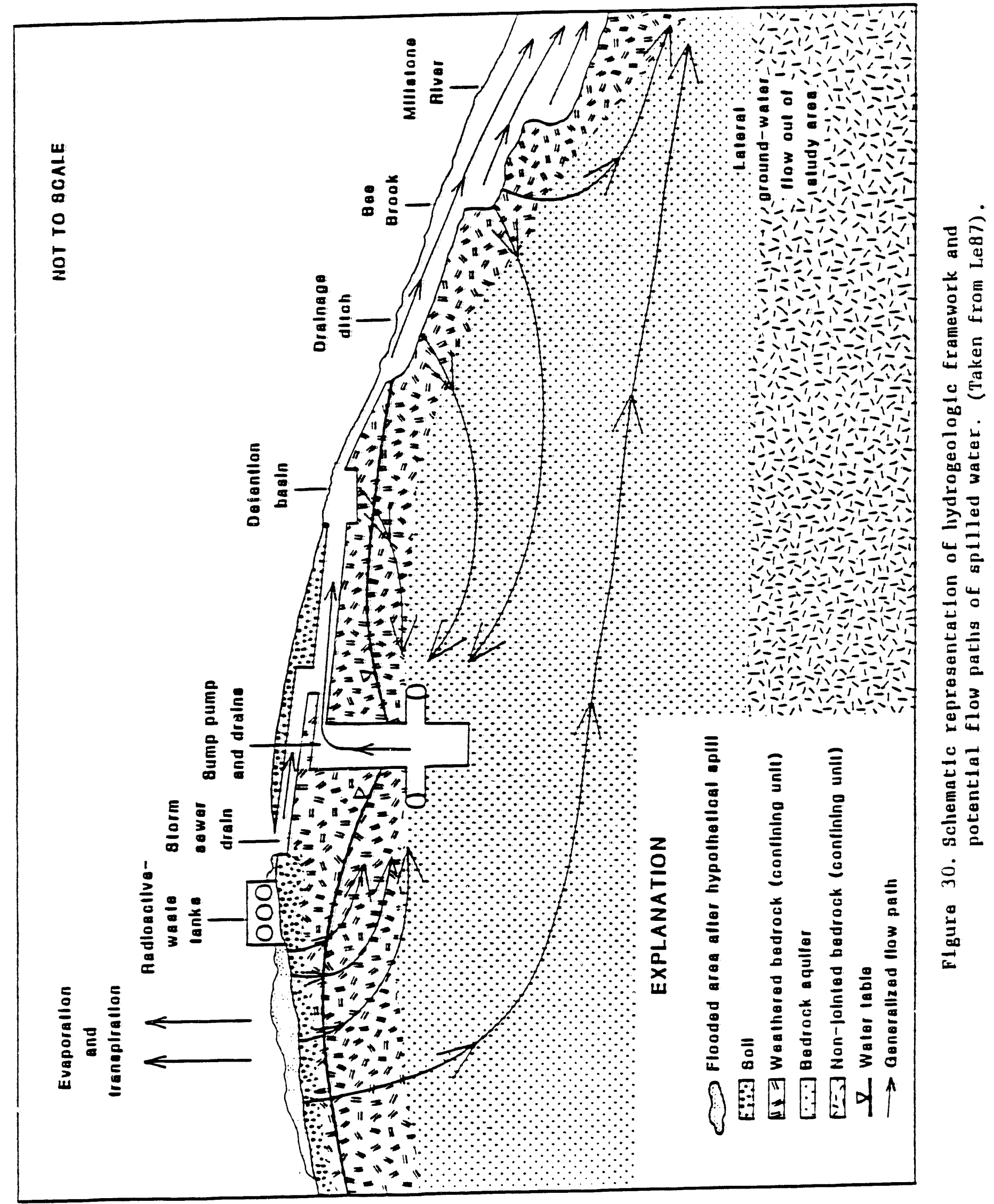




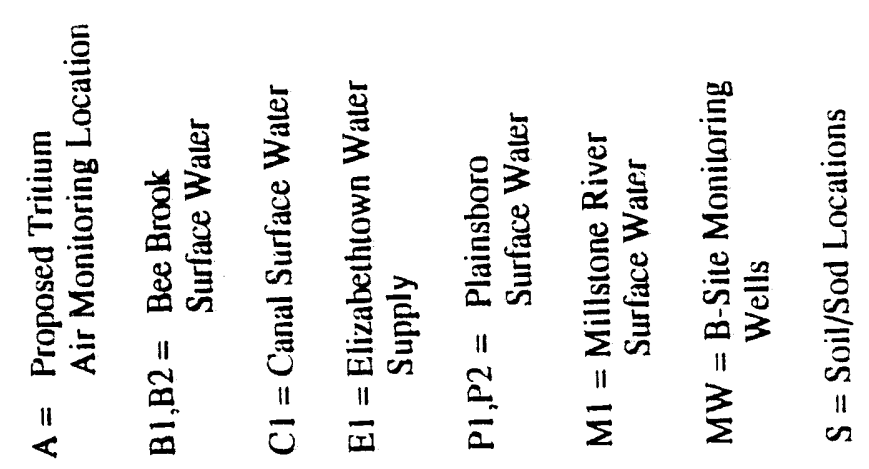

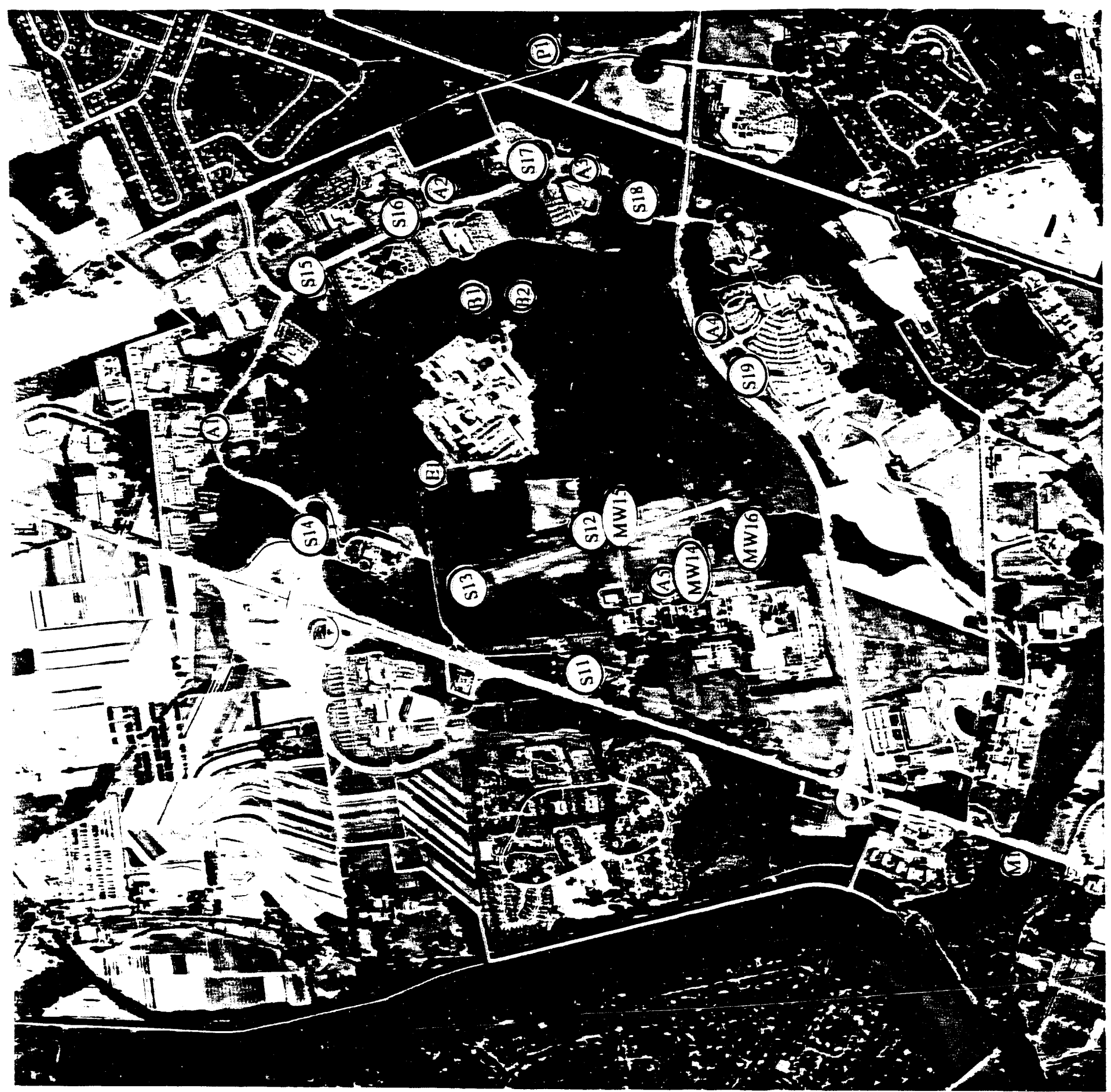




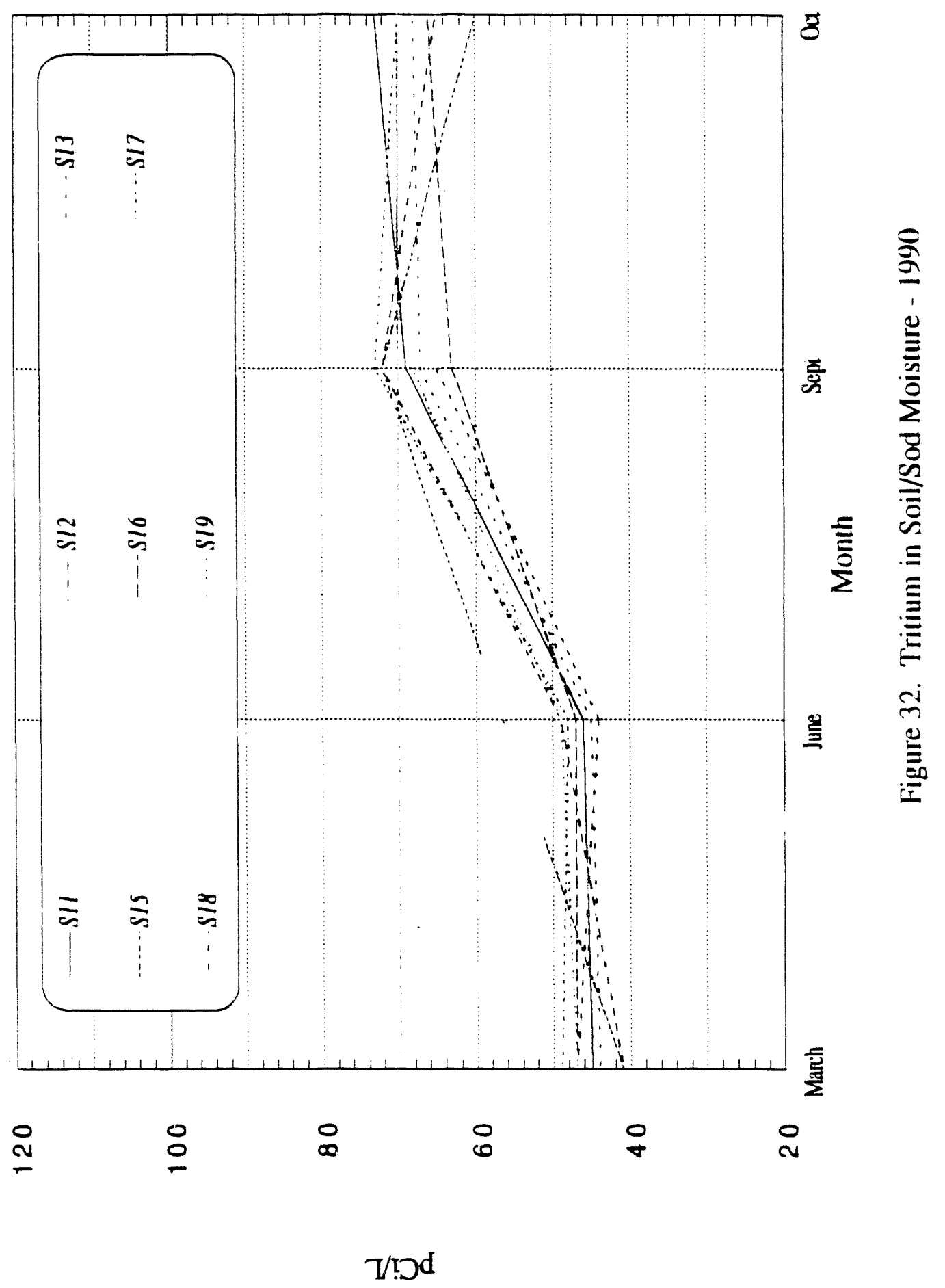




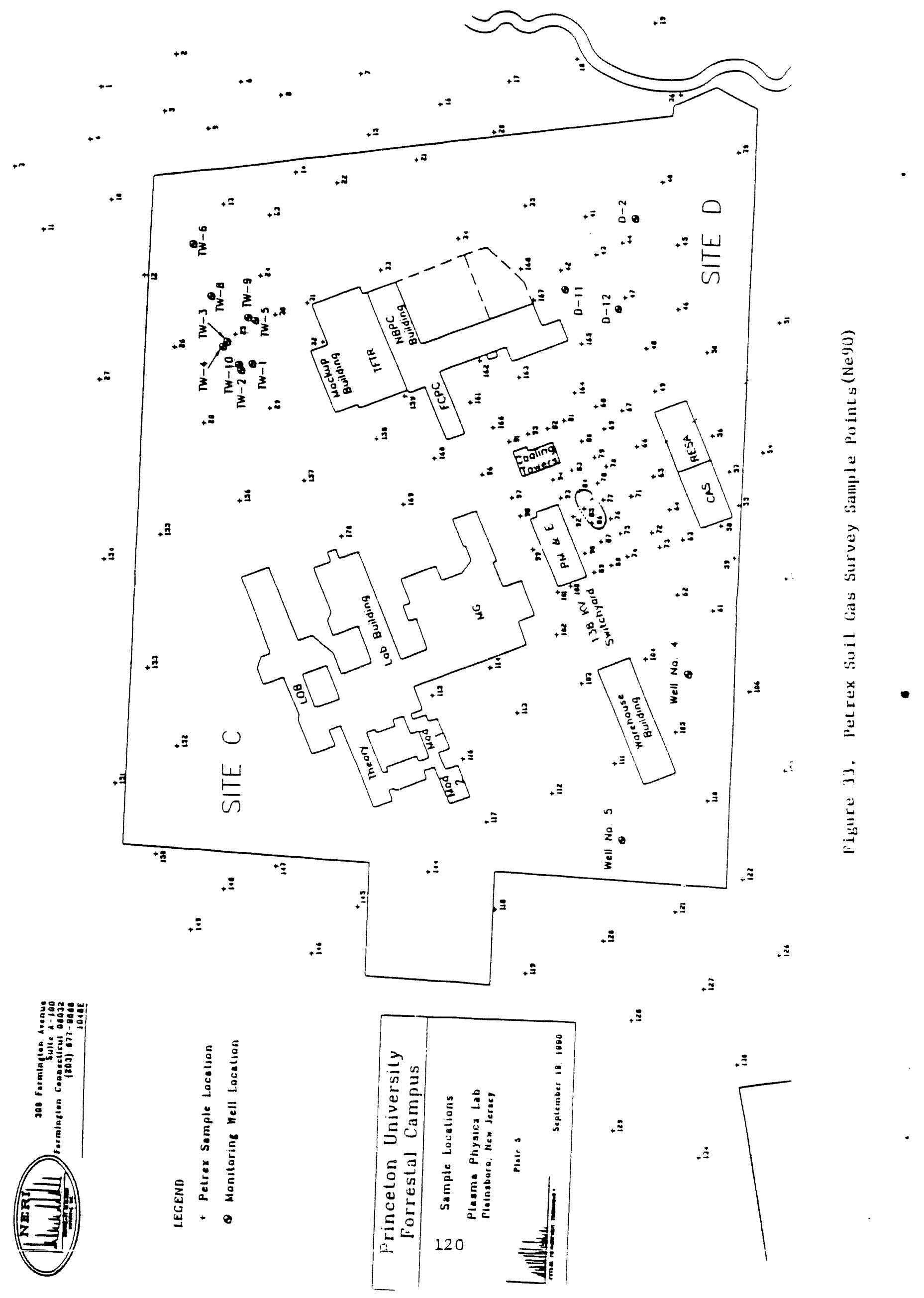




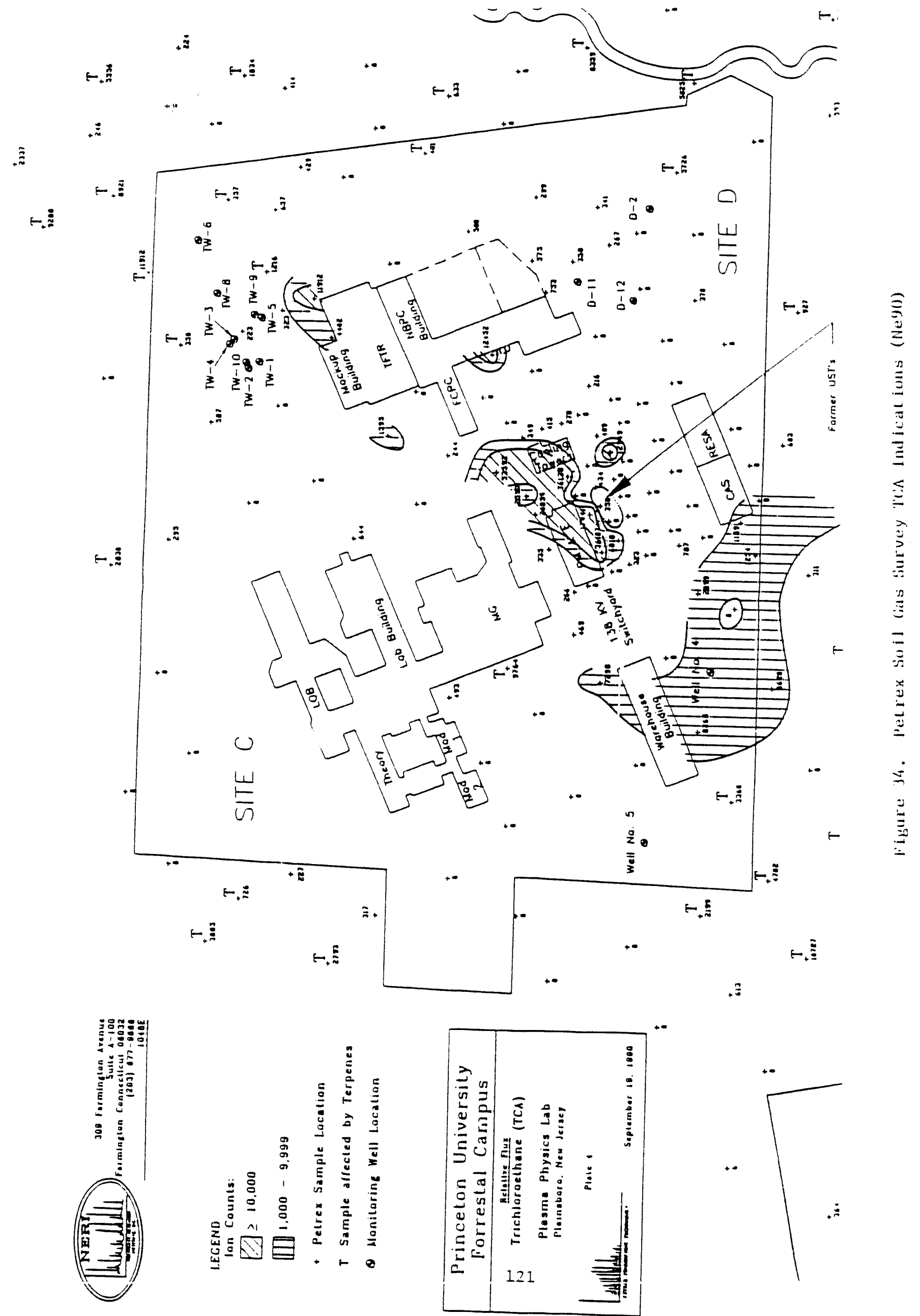




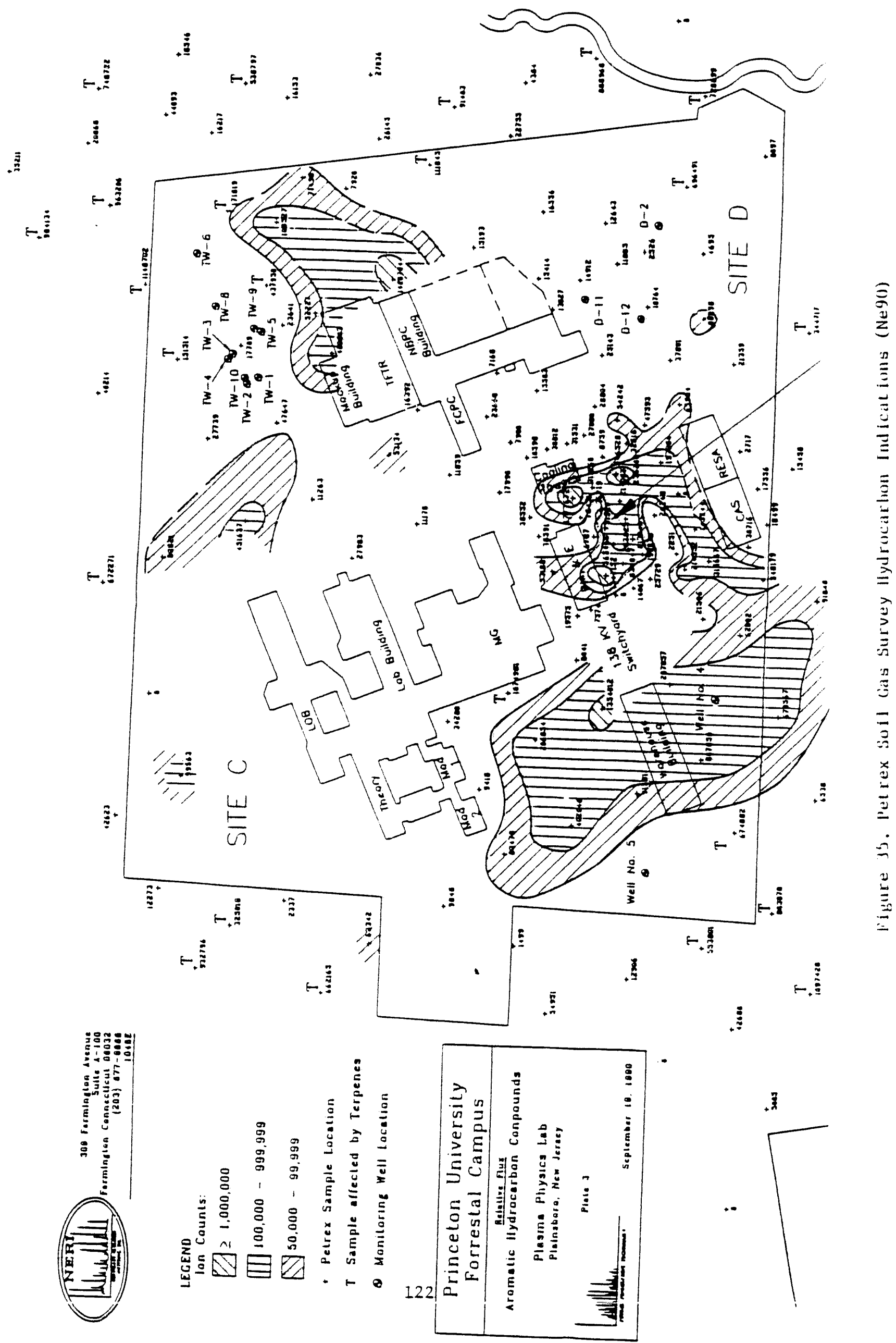




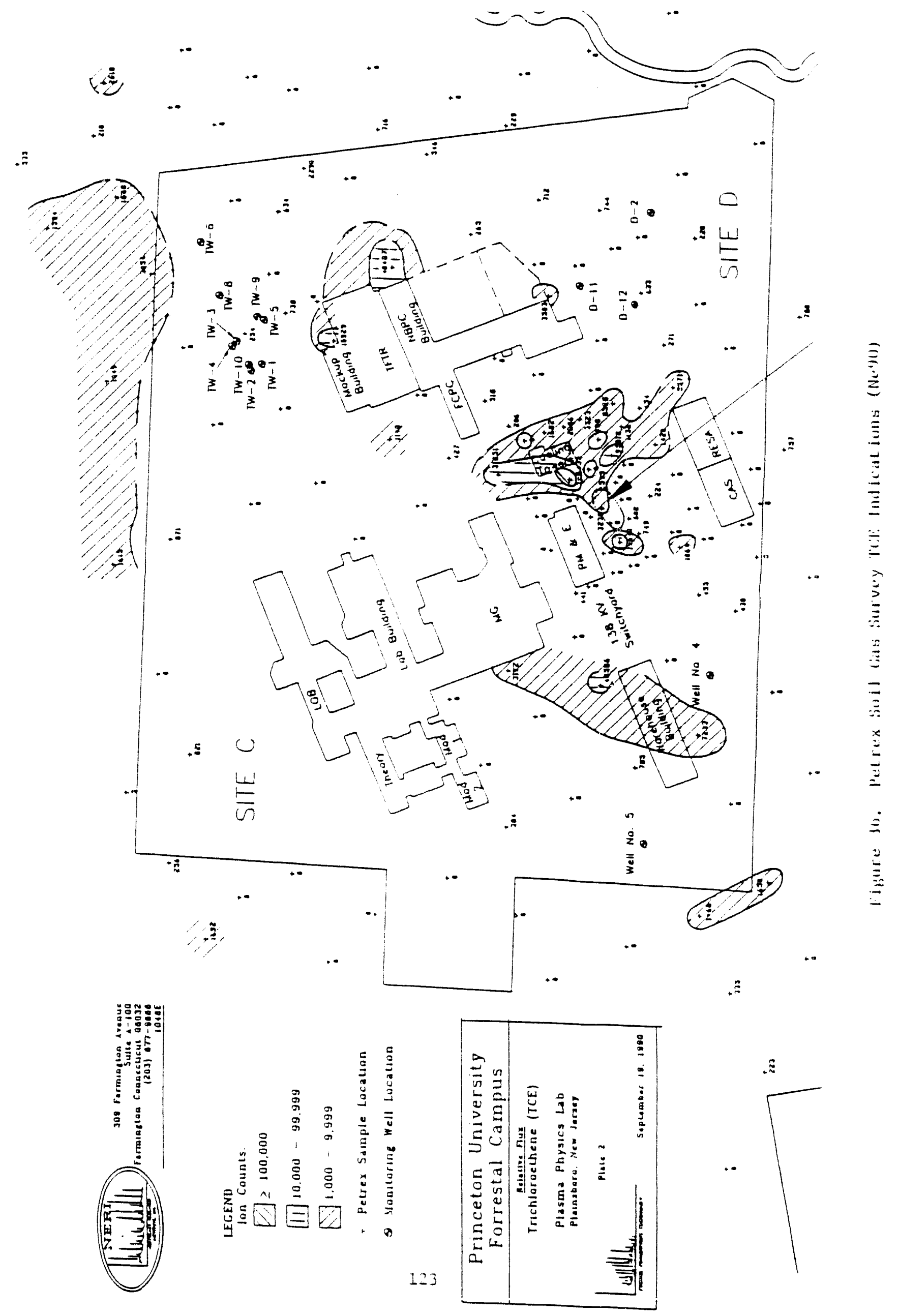




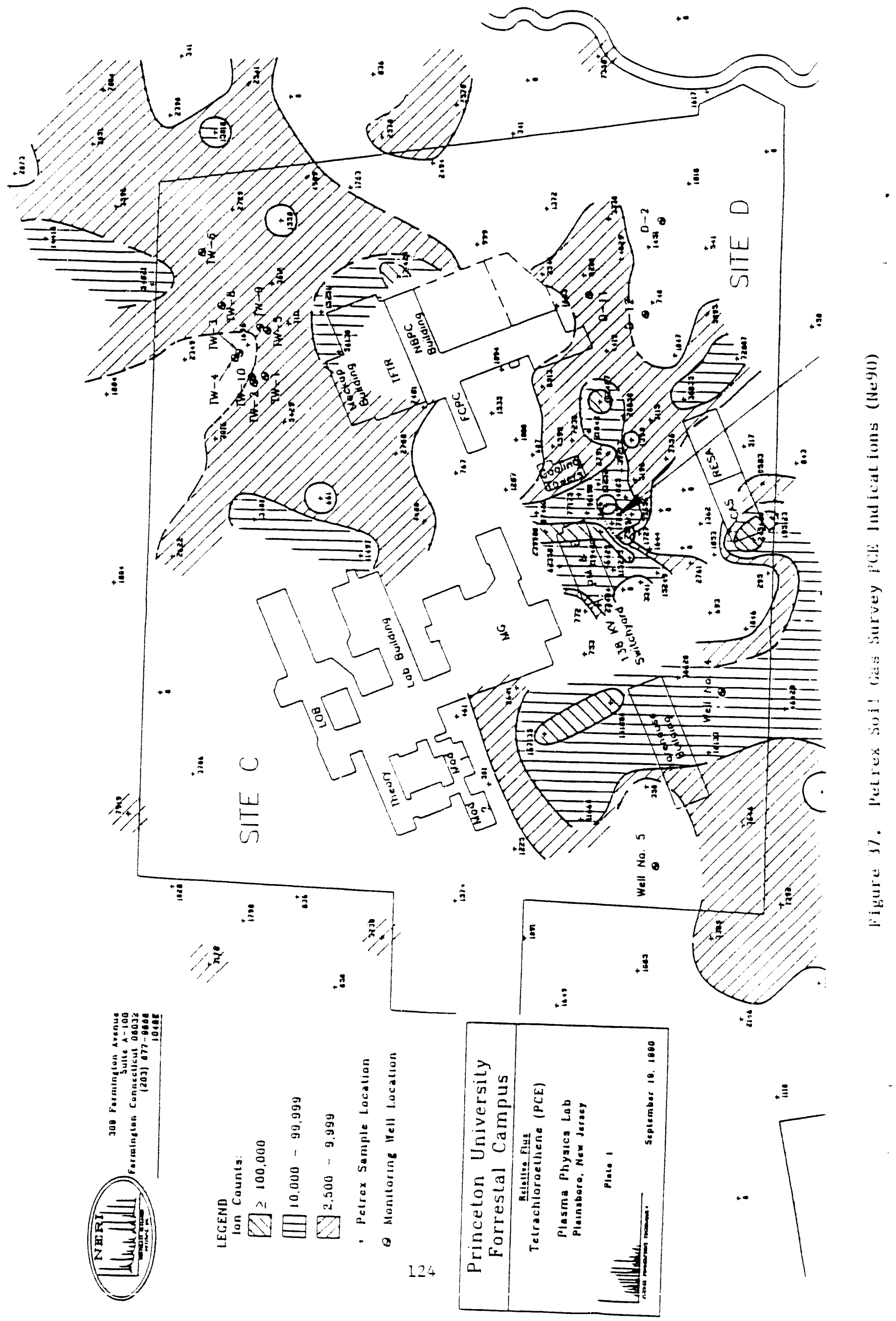



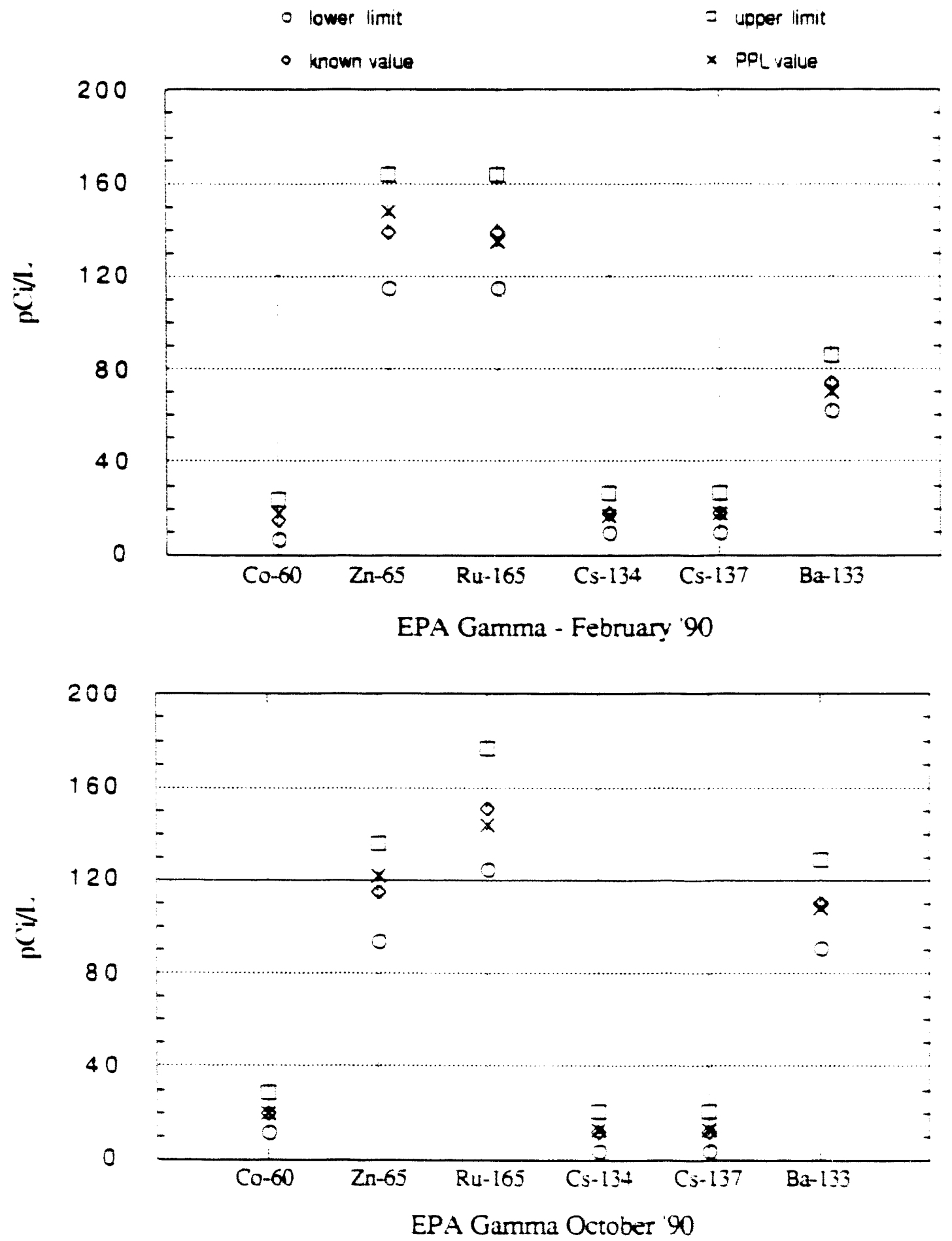

Figure 38. EPA-Las Vegas QA OCWater Samples for Gamma 


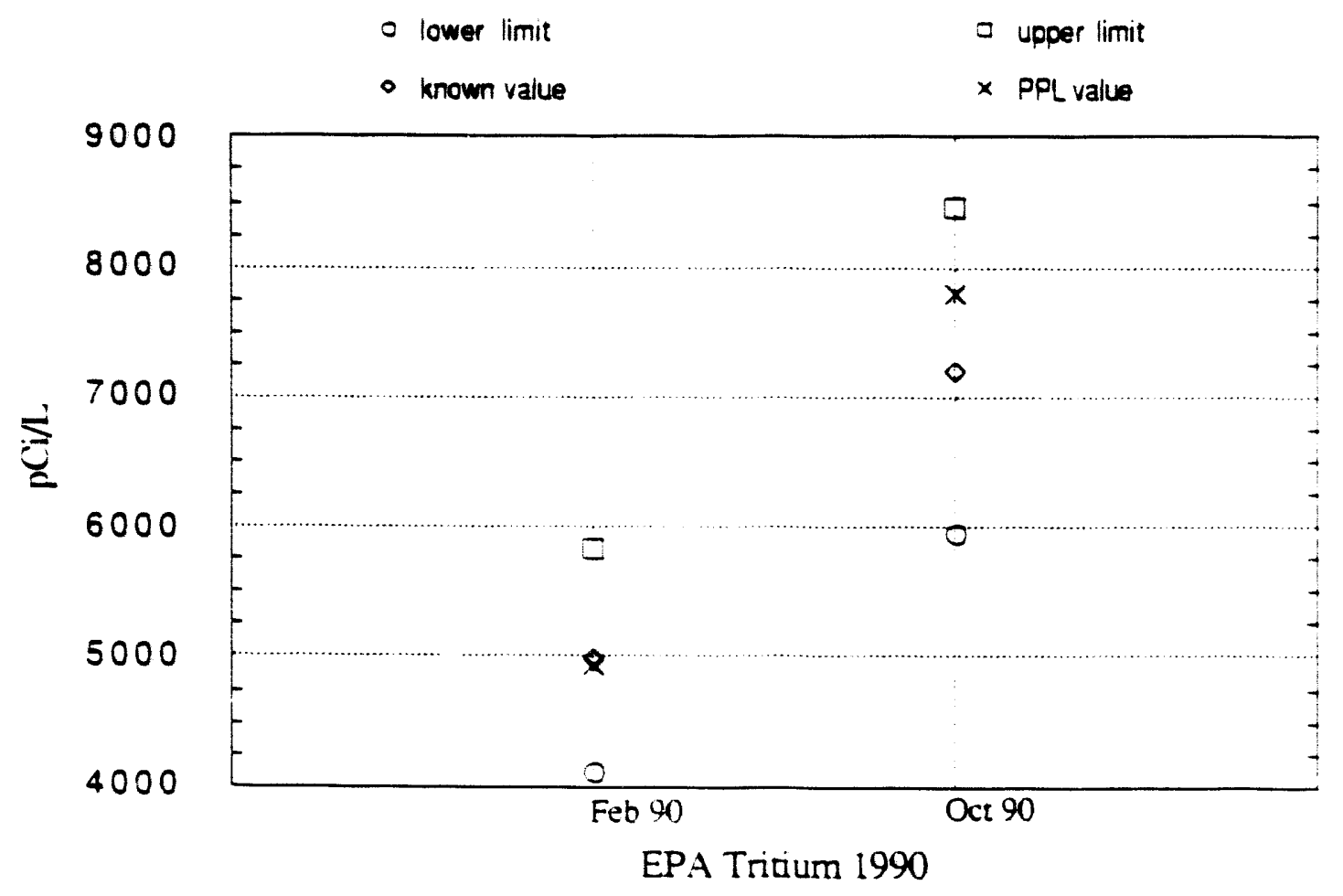

Figure 39. EPA-Las Vegas QA/OC Water Samples for Tritium 
Other Distribution

Argonne National Laboratory (R. Kolzow)

Brookhaven National Laboratory (J. Naidu)

CEBAF (G. Stapleton)

Congress (Sen. W. Bradley, Sen. F. Lautenberg, Cong. C. Smith)

DOE Chicago Operations (B. Fritz) [3]

DOE Environmental Audit, EH-24 [2]

DOE Otfice of Environmental Guidance and Compliance, EH-23 [5]

DNE Office of Fusion Energy, ER-55

DOE Office of NEPA Project Assistance, EH-25 [2]

DOE Princeton Area Office (H. Hix) [3]

EPA/HQ (William Gunther)

EPA/Region II

Fermilab (J. Don Cossairt)

Forrestal Development Center (R. Wolf)

General Atomics (R. Savercool)

Lawrence Livermoore National Laboratory (E. B. Hooper, S. F. Eccles)

Los Alamos National Laboratory (W. E. Quinn)

Idaho National Engineering Laboratory (L. Cadwallader, D. Holland)

Massachusetts Instiute of Technology (C. Fiore)

Middlesex Health Department

NJDEP, Bureau of Environmental Radiation (G. Nicholls) [2]

NJDEP, Bureau of Hazardous Waste Management

NJDEP, Bureau of Planning \& Site Assessment (L. Adams)

NJDEP, Division of Water Resources, Bureau of Aquifer Protection (G. Nichollas)

NJOEM, Division of Law \& Public Safety (C. Williams)

ORNL (J. Glowenika)

Omni-Environmental (M. Dimino)

Plainsboro Township (Glenn Carter) [2]

The Princeton Packet (W. Plump)

SAIC (M. McKenzie-Carter)

SSC (L. Coulson)

PPPL:

H. L. Allen

E. C. Brolin

J. Caruso

R. C. Davidson

J. De Looper

A. R. DeMeo

H. Ende

$\checkmark$. Finley

J. D. Gilbert

R. Hawryluk

R. D. Holt

H. Howard

S. M. Iverson

C. Kircher

S. B. Larson

R. Kaeser

D. M. Meade

K. Norcross

P. H. Rutherford

N. Sauthoff

J. A. Schmidt

E. D. Simon

J. Sinnis

W. Slavin

H. F. Sonnenchein [10]

R. A. P. Sissingh

J. R. Stencel

K. M. Young

M. Williams

E. H. Winkler

J. D. Levine

L. Wohar 
Dr F Paolom Univ of Wollongong. AUSTRALJA

Prof MH Bremnan. Univ of Sydroy. AUSTRALIA

Plasma Research Lab. Ausodian Nat. Unvy. AUSTRALIA

Prot IR Jones. Finders Univ. AUSTRAuA

Prot F Cap. Inst tor Meoreveal Physics. AUSTRIA

Prot M. Heindler, Insaut hur Theorousche Physik. AUSTRIA

Prof. M. Goossens. Astronomisch instuwe BELGIUM

Ecole Royad Militere, Lab of Phy. Plasmas. BELGIUM

Commission-Europaen, DG. XIl-Fusion Prog., BELGIUM

Prot. R. Boucieje. Pijksunmarswert Gent, BELGIUM

Dr. F'H. Satanake Instruto Fisica. BPVZZL

Inste ito De Pesquass Especies-INPE, BRNZIL

Dociments Orice. Alomc Energy of Canade LD. CANADA

Dr M.P Bechynato, MPB Tectmologies, Inc., CANADA

Dr H.M. Skeragerd. Unv of Sastrathowen. CANADA

Prot. J. Tecchmann. Unv of Montred. CANAOA

Prot S.R. Sraenvesen. Unn of Cagery. CAMADA

Prof TW. Johnston. INAS-Energe. CANADA

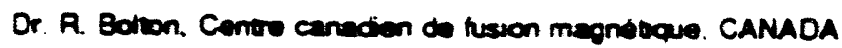

Dr C.R. Jemes. Univ. of Aborta. CANADA

Dr. P Lutace, Komenstaho Unmerszte. CZECHOSLOVAKIA

The Libreren, Cunam Laboratory. ENGLANO

Library. R61, Ruthertord Acpleton Laboratory. ENGLAND

Mrs. SA. Hutchinson. JET Lbrary. ENGLAND

$P$ Mathonen. Univ. of Haisunto. FINLAND

C Moutor Lab de Physaque des Miliaux lonisos. FRANCE

J Rader CEN/CADARACHE - Bar 506, FRANCE

Ms. C Rinm. Unn of loannina GREECE

Or T. Mal. Acadermy Bibliographic Ser. HONG KONG

Prepnnt Lubrary. Hunganan Academy of Sa. HUNGARY

Dr B. Das Gupe Sana inst. of Nudear Physics. INDIA

Dr P Kaw, Inst tor Plasma Research, INOIA

Dr P Rosenau. Isreal inst of Tectmology. ISRAEL

Libranan. Intematonal Center for Theo Physics. ITALY

Miss C. Do Palo. Assoczazione EURATOMLENEA. ITALY

Dr G Grosso. Istruso di Fisica ded Plasma. ITALY

Dr 4 Yamato. Tostiba Res a Dovel Centor, JAPAN

Prof I Kawatcarm. Abmuc Energy Res Inst. JAPAN

Prof K Nishikewa. Hiroshima Univ, JAPAN
Drector, Japan Abomic Energy Rosearch Inst. JAPAN

Prot. S Iton. Kyustou Unn, JAPAN

Dat and Planning Conter. Nagoya Univ. JAPAN

Prof S Tanaka. Kyoto Unn. JAPAN

Lbrery. Kyoto Univ, JAPAN

Prot N. Inoue. Unn of Tokyo. JAPAN

S. Mon. Technical Aovisor. LAEAI. JAPAN

- Mitare. Kumanoto inst of Technology. JAPAN

H Jeong. Korea Advanced Energy Roseerch Inst. KOREA

Prof D.I. Choi. The Koree Aor Inst of Sa 1 Tech, KOREA

Prot. B.S. Liby. Univ of Waikas. NEW ZEALAND

Inst. of Plasme Physes. PEOPLES REPUBLIC OF CHINA

Librenion. Inse of Ptysics. PEOPLES REPUBUC OF CHINA

Lorey. Tsinghe Unv. PEOPLES REPUBLIC OF CHINA

Z. U. S.W. Inat Physica, PEOPLES REPUBUC OF CHINA

Prof J.A.C. Gebre, Instauto Supenor Teconico. POATUGAL

Dr. O. Poorus. AlI CUza Univ. Romania

Dr. J. d Vilimers. Fusson Sudies. AEC. S. AFRICA

Prot. M.A. Hellogrg. Univ. of Nate, S. AFAICA

C.I.E.MA.T. Fusion Division Library. SPAIN

Dr L Simmo, Univ of UMEA, SWEDEN

Librey. Roye inst of Tectnology. SWEDEN

Prof. H. Whatmson, Chamers Univ of Tech., SWEDEN

Conese Phys. Des Plasmas, Ecole Polyech, SWITEERLAND

Bidiotheak. Inst. Voor Pleamafyerca. THE NETHERLANOS

M. Durgut Vico Chammen. Modto East Tech. Univ., TURKEY

Dr O D. Ayutov. Siberian Branch of Academy of Sa., USSR

Dr. G.A. Eliseev. Kurctiator inst, USSA

Lurenan. The Uler.SSR Academy of Saences. USSR

Dr. LM. Kovnzunyteh, Inst of Genord Physics. USSR

Kemtorschungsentage GmbH. Zentrabibiothek. W. GEAMANY

Bibliothate Inst. Fur Plasmatorscthung. W. GERMANY

Prot. K Sctinder, Ruhr-Unwersutt Bochum, W GERMaNY

Dr F Wapner, (ASOEX). Max.Planck-Insotut W GERMANY

Lubranan, Max-Planck-Insobut W GERMANY

Prot. R.K. Janev, Inst of Physics. YuGOSLAVIA 

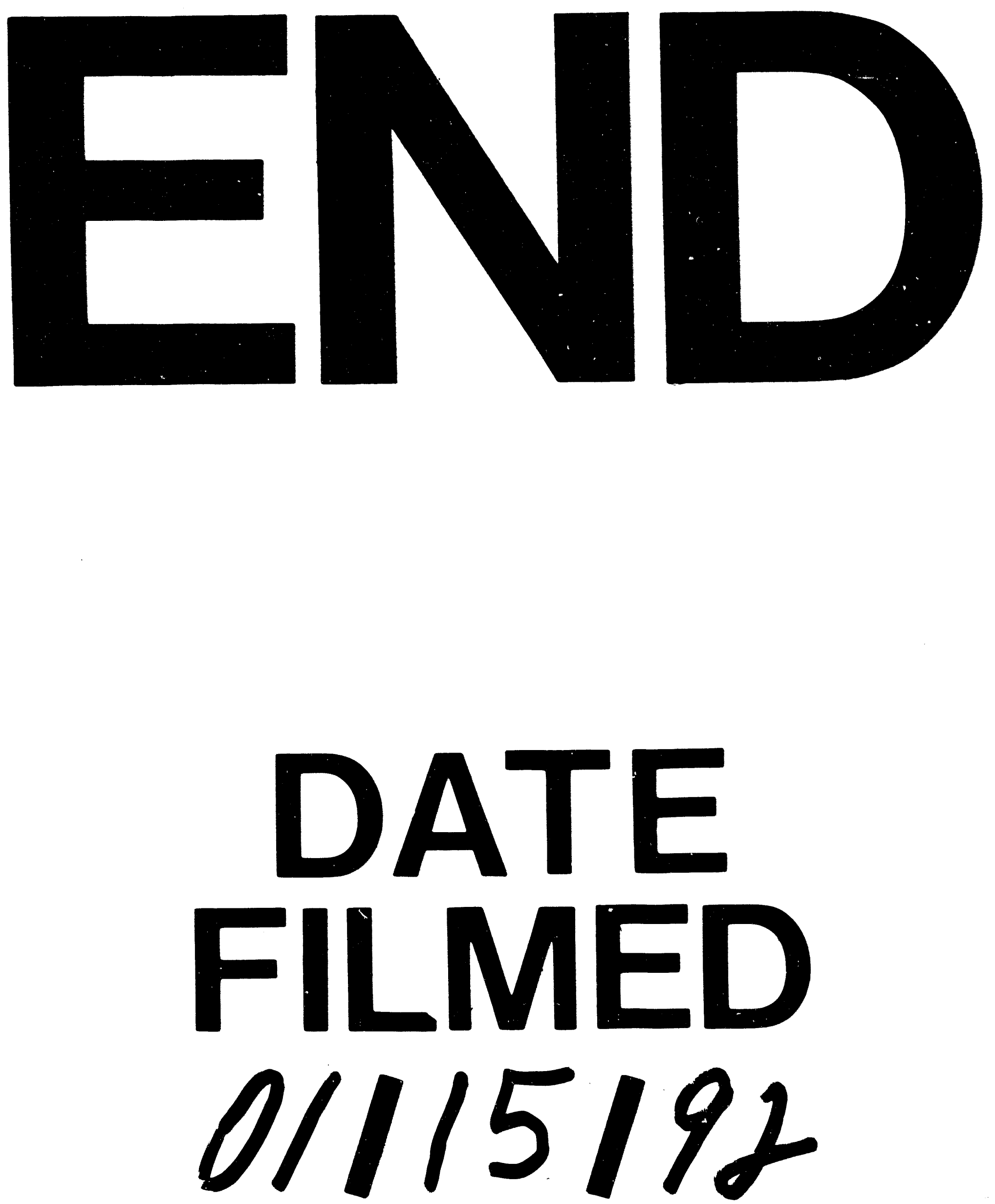